\title{
DEVELOPMENTS IN THE LAW SECTION 1983 AND FEDERALISM
}

Every person who, under color of any statute, ordinance, regulation, custom, or usage, of any State or Territory, subjects, or causes to be subjected, any citizen of the United States or any other person within the jurisdiction thereof to the deprivation of any rights, privileges, or immunities secured by the Constitution and laws, shall be liable to the party injured in an action at law, suit in equity, or other proper proceeding for redress.

42 U.S.C. $\S 1983$ (1970)

\section{TABLE OF CONTENTS}

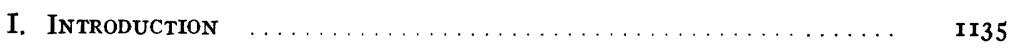

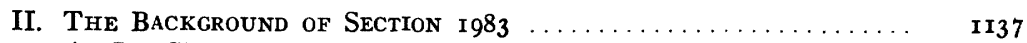

A. Pre-Civil War Federalism ...................... $\mathrm{II}_{138}$

B. Section 1983: The Original Understanding ............. II4I

I. The Reconstruction Amendments ................. II II

2. The Expansion of Federal Jurisdiction ............. $\mathbf{1 1 4 7}$

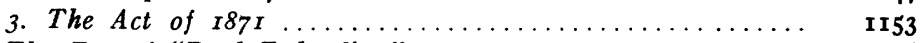

C. The Era of "Dual Federalism" .................... 1156

1. Civil Rights Enforcement ..................... ${ }_{1156}$

2. Views of Federalism ....................... II6I

D. The Emergence of Section $1983 \ldots \ldots \ldots \ldots \ldots \ldots \ldots \ldots \ldots$

E. Federalism and Modern Constitutional Theory ............ 1175

I. The First Principle: States as Governments .......... I179

2. The Second Principle: Effectiveness ............. 1183

III. Substantive Limits on Liability and Redief . . . . . . . . .

A. Defining a "Person" Under Section $1983 \ldots \ldots \ldots \ldots \ldots \ldots$ I 391

I. Municipal and Governmental Immunities ........... IIgI

2. Personal Immunities ........................ $\quad 1197$

B. State of Mind Requirements .................... 1204

I. Negligence Liability ....................... 1205

2. Qualified Immunities: The Good Faith Defense ......... 1209

C. The Section $1988_{3}$ Damage Action .................. 1217

D. The Section 1983 Injunction Action: "Public
Law" Adjudication $\ldots \ldots \ldots \ldots \ldots \ldots \ldots \ldots \ldots \ldots \ldots \ldots \ldots \ldots \ldots$

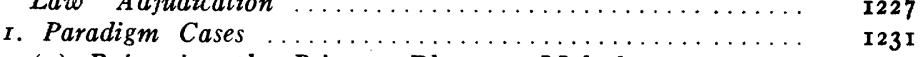

(a) Reforming the Prisons: Rhem v. Malcolm .......... $123 \mathrm{I}$

(b) Desegregating the Schools: Morgan v. Kerrigan....... ${ }_{1236}$

2. The Legitimacy of Systemic Relief ............... 1240

3. An Incremental Approach to Systemic Relief .......... 1247

IV. Pullman Abstention ............................. 250

A. The Threshold for Considering Abstention:
The Need to Decide an Unclear Question of State Law ...
$\mathbf{1 2 5 4}$ 
B. The Likelihood and Impact of Error in Federal Decisions of Unclear Questions of State Law ........... 1257

V. Exhaustion $\ldots \ldots \ldots \ldots \ldots \ldots \ldots \ldots \ldots \ldots \ldots \ldots \ldots \ldots \ldots \ldots \ldots \ldots$

VI. The Younger Doctrine $\ldots \ldots \ldots \ldots \ldots \ldots \ldots \ldots \ldots \ldots \ldots \ldots \ldots$

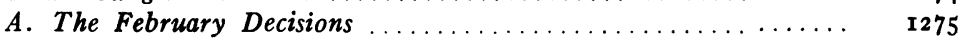

r. The Key Cases ......................... 1275

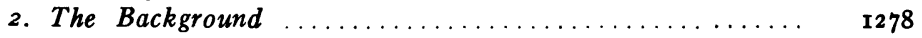

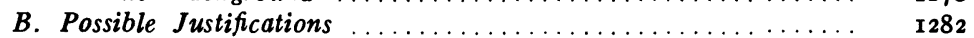

I. Forum Allocation Preferences ................. 1282

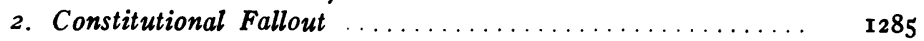

C. The First Limits $\ldots \ldots \ldots \ldots \ldots \ldots \ldots \ldots \ldots \ldots \ldots \ldots \ldots \ldots \ldots$

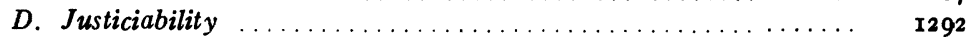

E. Coverage Rules ............................ 1301

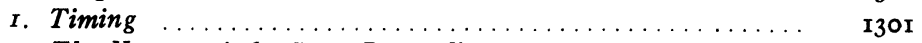

2. The Nature of the State Proceeding . . . . . . . . . . . 1308

3. Derivative Preclusion ...................... $13 \mathrm{I}_{4}$

4. The Nature of the Plaintiff's Claim ................ 13 7

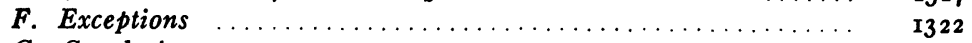

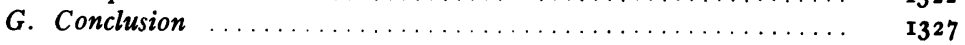

VII. The Preclusive Effect of Prior State and Federal Judgments 1330

A. The Res Judicata Effect of Prior State Court

Judgments on Subsequent Section 1983 Actions .......... 1331

r. Nonparallel Actions: Declaratory Judgments

Subsequent to State Proceedings ............... 1343

2. Parallel State and Federal Suits ............... 1347

B. The Effect of Federal Declaratory Judgments on

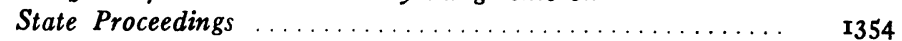

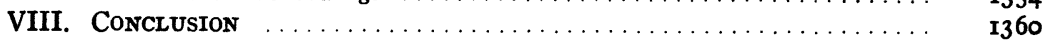




\section{INTRODUCTION}

The relationship between the themes of federalism and individual rights is one that runs deep in American intellectual and social history. And it is one that has changed drastically with changes in the conditions and temperament of our society. ${ }^{1}$

In the early days of the Republic, federalism was viewed as a means of protecting individual rights from the tyranny of a unified central government. The Civil War brought with it a rejection of this guiding principle. State autonomy came to be seen not as a means to protect the individual from government abuse but rather as the primary source of that abuse. Unpopular or disadvantaged minorities, unable to protect themselves when isolated within the processes of states and localities, turned to the federal government and the federal courts with increasing frequency - and increasing success. The trend culminated in the 1960's: where individual civil rights were implicated, concern for the interests of states as such was sharply reduced. ${ }^{2}$

In recent years, the pendulum seems to have swung in the opposite direction. The national mood has displayed increasing disenchantment with centralized power; the decisions of the Supreme Court have evidenced increasing solicitude for the interests and prerogatives of states. ${ }^{3}$ And inevitably, a sense of conflict has emerged between the developing recognition that states $d o$ mean something in a federal system and the belief that a primary role of the federal government - through its Constitution, laws, and courts - is to provide protection for civil rights against state abuse.

This contemporary conflict between federalism and civil rights is posed perhaps most sharply in lawsuits brought against state and local officials in federal court under 42 U.S.C. $\S 1983{ }^{4}$ Section 1983, enacted as part of the Civil Rights Act of $187 \mathrm{I}$ to enforce the guarantees of the fourteenth amendment by providing a cause of action in federal court, ${ }^{5}$ lay dormant as a result of restrictive judicial construction until the Supreme Court's I96I

${ }^{1}$ See, e.g., B. Marshall, Federalism and Civil Rights (1964); Howe, Federalism and Civil Rights, 77 Mass. HIST. Soc'y Proc. I5 (1965); Note, Theories of Federalism and Civil Rights, 75 YALE L.J. 1007 (1966).

${ }^{2}$ See pp. II 76-77 infra.

${ }^{3}$ See, e.g., National League of Cities v. Usery, 426 U.S. 833 (1976); Hughes v. Alexandria Scrap Corp., 426 U.S. 796 (1976); Rizzo v. Goode, 423 U.S. 362 (1976); Village of Belle Terre v. Boraas, 4 I6 U.S. I (1974).

${ }^{4} 42$ U.S.C. § 1983 (1970).

${ }^{5}$ See pp. I153-56 infra. 
decision in Monroe v. Pape. ${ }^{6}$ In the succeeding decade and a half, litigation under the statute has burgeoned, ${ }^{7}$ but as the volume of I 983 litigation has expanded, so too have the calls for its restriction. ${ }^{8}$

This Note will examine the enforcement of constitutional rights under section 1983 in light of the enhanced contemporary concern with state autonomy and integrity. In doing so, the goal is not only to suggest the ramifications of the concern with state interests on the 1983 action, but also to give some content to the vague contours of "Our Federalism."

Part II examines the history of section 1983 against the background of events and evolving theories of federalism that have shaped its development. The succeeding Parts deal with the product of that development. Part III focuses on the standards governing liability under section 1983 and the availability of damages and injunctive relief. Parts IV, V, and VI examine the judicially created doctrines which may restrict or foreclose the I 983 plaintiff's access to a federal forum: the abstention, exhaustion, and Younger doctrines. Even if it were no longer true as it was when the Civil Rights Act of $187 \mathrm{I}$ was passed and a choice of a federal forum for 1983 actions guaranteed ${ }^{9}$ - that state forums are generally less able or willing to enforce constitu-

${ }^{6} 365$ U.S. 167 (196r).

${ }^{7}$ In 1960 , only about 300 federal suits were filed under all the civil rights acts. Administrative Office of the United States Courts, ig6o Annual Report of THE Director 232, table $\mathrm{C}_{2}$. By I972, approximately eight thousand suits were filed under $\S 1983$ alone. See McCormack, Federalism and Section 1983, 60 VA. L. Rev. I, I n.2 (1974). In fiscal 1976 , of the 140,189 civil actions pending in the federal courts, $12,91 \mathrm{I}$ of them were general civil rights actions; in addition, there were approximately $6,34 \mathrm{I}$ state prisoner civil rights actions. ADMINISTRATIVE Office of the United States Courts, i976 Annual Report of the Director 86. One authority estimates that in 1976 , almost one-third of the nearly 57,000 private federal question cases filed in the federal district courts were civil rights actions asserting constitutional claims against state and local officials. P. BATOR, P. Mishkin, D. Shapiro \& H. Wechsler, Hart \& Wechsler's The Federal Courts and the Federal System i49 (2d ed. Supp. 1977).

${ }^{8}$ See, e.g., H. Friendly, Federal Jurisdiction: A General View go-ioo (x973) ; Aldisert, Judicial Expansion of Federal Jurisdiction: A Fuderal Judge's Thoughts on Section 1983, Comity and the Federal Caseload, r973 Law \& Soc. ORD. 557 ; pp. $1265-66$ infra.

${ }^{9}$ The jurisdictional counterpart of $\S \mathrm{I} 983$, also originally part of $\S \mathrm{I}$ of the Civil Rights Act of $187 \mathrm{I}$, is currently codified at 28 U.S.C. $\$ 1343$ (3) (1970). It bestows jurisdiction, without regard to the amount in controversy, on the federal district courts over all substantive causes of action for the deprivation of all rights secured by the Federal Constitution, and those rights secured as well by "any Act of Congress providing for equal rights." See Lynch v. Household Fin. Corp., 405 U.S. 538 (i972) ; P. Bator, D. Shapiro, P. Mishikin \& H. Wechsler, Hart \& Wechsler's The Federal Courts and the Federal System 95i-6i (2d ed. 1973). 
tional rights than their federal counterparts, ${ }^{10}$ forced resort to state remedies under one of these doctrines would burden or deprive the constitutional plaintiff of an opportunity to decide whether a particular state or federal forum is likely to prove more sympathetic to his claim. Finally, Part VII examines the application of res judicata principles to civil rights decisions in both state and federal courts.

\section{The Background of Section i983}

In its modern interpretation of section 1983 , the Supreme Court has, to a considerable extent, purported to rely upon the legislative history of the statute. The seminal decision in Monroe v. Pape, ${ }^{1}$ which gave new life to the long dormant Civil Rights Act, and the subsequent opinions detailing the components of the section 1983 cause of action and the scope of the statutory exemptions, have all drawn heavily upon the debates of the Reconstruction Congresses. ${ }^{2}$

Such heavy reliance on legislative history would alone justify an examination of the Reconstruction debates and of the historical context in which section 1983 was enacted. But perhaps more importantly, history, while not necessarily determinative of present dilemmas, may frame the questions which must be addressed and relate past responses which can inform modern situations. ${ }^{3}$ In this Part, it will be suggested that many of the concerns which prompted the enactment of the Civil Rights Act of $187 \mathrm{I}$ have contemporary analogues, and that the widespread breakdown in law enforcement in the post-Civil War South has parallels in kind, if not in degree, with current instances of systematic deprivations of - or failures to enforce - constitutional rights. ${ }^{4}$ By placing the statute in the context of the evolving role of the federal government in the protection of individual rights, ${ }^{5}$ and by delineating the interests and concerns which make atten-

${ }^{10}$ See pp. I150-51, II54-55 infra.

${ }^{1} 365$ U.S. 167 (196r); see pp. 1169-71 infra.

${ }^{2}$ See, e.g., Aldinger v. Howard, 427 U.S. I, 24 (1976) (Brennan, J., dissenting) ("the sole rationale for construing the 'persons' susceptible of liability under section 1983 as excluding local units of government lies in the legislative history"); City of Kenosha v. Bruno, 4I2 U.S. 507, 5 13 (1973); Monroe v. Pape, 365 U.S. 167, 172-92 (r96r).

${ }^{3}$ See generally C. Miller, The Supreme Court and the Uses of History 200 (1969); Wofford, The Blinding Light: The Uses of History in Constitutional Interpretation, 3 I U. CHI. L. REV. 502, 528 (I964).

${ }^{4}$ Compare pp. II53-56 infra with pp. I231-39 infra.

${ }^{5}$ See pp. II76-77 \& nn. 247-50 infra. 
tion to federalism meaningful today, this Part will attempt to provide a basis for resolution of the conflict between the protection of individual rights and respect for state interests which underlies the contemporary dispute over the interpretation of section 1983 .

\section{A. Pre-Civil War Federalism}

Prior to the Civil War, most thinking about federal-state relations emphasized the autonomy of the national and state governments and the primacy of the states as the centers of political and economic life. ${ }^{6}$ Although political scientists have recently suggested that even during the first half of the nineteenth century there was considerable federal-state cooperation in the implementation of government programs, ${ }^{7}$ the rhetoric of the times pictured the nation and the state as two governments, with each restricted to its sphere of action, independent of the other and supreme in its respective sphere. ${ }^{8}$ The national government was seen as one of limited powers whose operations were closely confined to the few areas of national concern enumerated in the Constitution. The bulk of the power of government - what was later referred to as the police power - was retained by the states, who assumed the primary responsibilities of government, including the definition and protection of civil rights. ${ }^{9}$

The assumption of a perfect dualism between the national and state governments derived in part from the popular view of the nature of the Constitution. During the Federalist era, the dominant analysis saw the people of the nation as a whole as the source of the Constitution's authority. This enabled the Federalists to urge an expansive role for the national government notwithstanding the fact that parts of their program trenched on the prerogatives of the states; since the state could not be considered sovereign, the question of the scope of national power could be resolved independently of the powers of the states. ${ }^{10}$

${ }^{6}$ See, e.g., W. Bennet, AMerican Theories of Federalism 9I-I59 (I964); E. Corwin, The Twilight of the Supreme Court 6 (I934); H. Hyman, A More Perfect Union 7-io (1973); R. Leach, American Federalism i2 (I970); I S. Morison \& H. Commager, The Growth of the American Republic 434 (5th ed. 1962); Nichols, Federalism versus Democracy, in FEderalism AS A Democratic Process 49-75 (I942).

${ }^{7}$ See, e.g., M. Grodzins, The American System i8-4I (i966); L. White, The Jacksonians 309-io (I954).

${ }^{8}$ See, e.g., W. Bennetr, supra note 6, at 9I-125; E. CoRwIN, supra note 6, at 6.

${ }^{9}$ See H. Hyman, supra note 6 , at 8 ; Note, Theories of Federalism and Civil Rights, 75 YALE L.J. 1007, ror8-20 (1966); Elazar, Federal-State Collaboration in the Nineteenth-Century United States, 79 PoL. Scr. Q. 248 (1964).

${ }^{10}$ See, e.g., The Federalist No. 46 (J. Madison); W. Bennetr, supra note 6, at $83-85$; G. Wood, The Creation of the American Republic, I776-i 787, at 524-47 (1969). 
With the accession of the Jeffersonian Republicans to power in I 800 , thinking about the nature of the Constitution underwent a profound shift. ${ }^{11}$ The Jeffersonians asserted that the Constitution rested not on the will of the people but on a compact among "sovereign and independent" states; the Union was not a consolidated nation but a "league of nations." 12 Under this view, each state could decide for itself whether it would be bound by the actions of the national government or, indeed, by the Constitution itself. ${ }^{13}$

The incorporation of ante bellum state-oriented political theory into legal doctrine was modified and postponed, and the foundation for a more expansive view of national power laid, by the Chief Justiceship of John Marshall. In McCulloch v. Maryland ${ }^{14}$ and Gibbons v. Ogden ${ }^{15}$ Chief Justice Marshall indicated the potentially broad scope of national legislative power, finding that the necessary and proper clause added to rather than limited national authority, ${ }^{16}$ and construing the commerce clause to create congressional power to regulate to the "utmost extent" 17 "every species of commercial intercourse." 18 In these and other cases, the Marshall Court also rebutted the notion that when an act of Congress came into conflict with an otherwise valid state law, the two acts confronted each other on a basis of exact equality. ${ }^{19}$ The Court vindicated the principle of the supremacy of national law: that "the government of the union, though limited in its powers, is supreme within its sphere of action." 20 And the fact that certain subjects might fall within the reserved powers of the states was held insufficient to put them beyond the reach of Congress' enumerated powers. ${ }^{21}$ Finally, the Marshall

${ }^{11}$ See, e.g., E. Corwin, The Commerce Power Versus States Rights 1 75-76, 216-I9 (I936); I S. Morison \& H. Commager, supra note 6, at 299-300, 322, 349-5I.

${ }^{12}$ See W. Bennetr, supra note 6, at II8-ig (quoting John Taylor of Caroline).

${ }^{13}$ See generally id. at I22-25; E. CoRwin, supra note 6 , at 6 . In subsequent decades, as the conflict between the sections over slavery and economic development emerged and intensified, proponents of the states' rights position, such as John Taylor of Caroline and John C. Calhoun, were to urge that the states could interpose their will and nullify within their borders actions of the national government which they believed to be unconstitutional; more extreme theorists and politicians were eventually to urge the right of secession. See generally W. Bennett, supra note 6, at 100-59; Note, supra note 9, at 1018-20.

${ }^{14}$ I 7 U.S. (4 Wheat.) 316 ( 1819 ).

1522 U.S. (9 Wheat.) I (1824).

${ }^{16}$ I 7 U.S. (4 Wheat.) at $42 \mathrm{I}$.

${ }^{17} 22$ U.S. (9 Wheat.) at 190.

18 Id. at 196.

19 See generally J. Schmidhauser, The Supreme Court as Final Arbiter in Federal-State Relations, I789-1957, at 26-49 (1958).

${ }^{20}$ I 7 U.S. (4 Wheat.) at 405.

21 See E. CoRwIN, supra note II, at I22-24. 
Court established the Supreme Court as the ultimate arbiter of federal-state conflicts and the federal courts as paramount in the resolution of constitutional questions. ${ }^{22}$ Marshall Court decisions upheld the power of the federal courts to invalidate state legislation and to reverse the decisions of state courts on matters of constitutional interpretation. ${ }^{23}$ In Fletcher v. Peck ${ }^{24}$ and the Dartmouth College Case ${ }^{25}$ the Court vigorously enforced the contracts clause, at that time one of the few provisions of the Constitution which protected individual rights against state, as opposed to federal, interference; while in United States $v$. Peters ${ }^{26}$ and Cohens v. Virginia ${ }^{27}$ the Court invalidated state legislative and judicial efforts to limit federal jurisdiction to enforce federal law against the states. ${ }^{28}$

With the death of Chief Justice Marshall, however, the popularly accepted states' rights philosophy began to take hold on the Supreme Court as well. The Taney Court generally construed the powers of the national government to avoid projecting it into the internal activities of the states. ${ }^{29}$ Moreover, it interpreted the tenth amendment as a reservation to the states of a field of power beyond the reach of federal legislation. Perhaps the most extreme application of this "dual federalism" analysis was in New York v. Miln. ${ }^{30}$ Writing for the Court, Justice Barbour upheld a state law setting certain requirements for ships entering New York harbor with aliens on board, ${ }^{31}$ fiinding that with respect to "all those powers which relate to municipal legislation, or what may perhaps more properly be called internal police ... the authority of a state is complete, unqualified, and exclusive." 32

${ }^{22}$ See W. BenNetT, supra note 6 , at ro6.

${ }^{23}$ See, e.g., Cohens v. Virginia, I9 U.S. (6 Wheat.) 264 (1821); Martin v. Hunter's Lessee, I4 U.S. (I Wheat.) 304 (I8I6).

${ }^{24}$ Io U.S. (6 Cranch) 87 (I8Io). See also J. SchmidhaUSER, supra note 19, at $45-46$.

${ }^{25}$ Trustees of Dartmouth College v. Woodward, I7 U.S. (4 Wheat.) 5 I8 (I8I9).

${ }^{26} 9$ U.S. (5 Cranch) II 5 (1809).

${ }^{27}$ I9 U.S. (6 Wheat.) 264 (I82I).

${ }^{28}$ Id. at $407-30$; 9 U.S. (5 Cranch) at 136-40. See also W. Bennetr, supra note 6 , at I04-05; J. SCHMIDHAUSER, supra note 19 , at 28-45.

${ }^{29}$ See, e.g., The Passenger Cases, 48 U.S. (7 How.) 283 (1849). See generally

E. CoRwin, supra note 6 , at II-I2.

${ }^{30} 36$ U.S. (I I Pet.) I02 (I837).

${ }^{31} \mathrm{Id}$. at $\mathrm{I} 3 \mathrm{O}-3 \mathrm{I}$.

${ }^{32} I d$. at $\mathrm{I} 39$ (emphasis in original).

In addition to suggesting that there are some areas subject to government regulation which are by their nature beyond the scope of federal power, the Taney Court's sensitivity to the prerogatives of the state governments on occasion led it to limit the effects of federal law in areas admittedly within the ambit of proper federal activity. Thus, in Dred Scott v. Sandford, 60 U.S. (I9 How.) 393 (1857), 
The Taney Court's version of the states' rights creed was limited by the preservation of the principle of national supremacy. ${ }^{33}$ Congressional authority was exclusive and state legislation invalid in those areas of national concern demanding uniform treatment. While state legislation in the absence of congressional action was permissible where the subject, although one of national concern, allowed for variations in treatment from state to state, affirmative federal action pursuant to the commerce power could displace such state legislation. ${ }^{34}$

The Taney Court, then, enunciated a moderate version of the states' rights creed, but one consonant with the state-oriented character of contemporary political reality. Although the supremacy of federal law was generally established in theory, the scope of federal activity was limited and the states were largely shielded from federal power. The secession crisis and the Civil War, however, were to alter profoundly the ante bellum status of federal-state relations.

\section{B. Section 1983: The Original Understanding}

I. The Reconstruction Amendments. - The victory of the Northern armies and the infamy of secession effectively terminated this era of state independence and discredited expansive prewar theories of states' rights. And the new spirit of nationalism which marked the Civil War era was most evident in the area of civil rights.

The thirteenth ${ }^{35}$ fourteenth, ${ }^{36}$ and fifteenth ${ }^{37}$ amendments

the Court invalidated the Missouri Compromise of 1820 which had prohibited the introduction of slavery into most of the western territories. The Court found that in regulating the territories Congress could not legislate in such a manner as to impair rights guaranteed by state laws, such as the right to hold slaves. The national government was characterized as little more than a trustee and agent of the states, which were regarded as coproprietors of the territories. See id. at 44754. Similarly, in Kentucky v. Dennison, 65 U.S. (24 How.) 66 (I86I), the Court limited the effect of article IV, $\S 2$, which required the rendition of fugitives from justice to the state having jurisdiction over the crimes committed. Reasoning that a "mandatory and compulsory" interpretation of the clause might overload state officers and thereby disable them from performing their obligations to their own states, the Court concluded that the "Federal Government under the Constitution has no power to impose on a state officer as such any duty whatever and compel him to perform it." Id. at 108, 109-110.

${ }^{33}$ It has been noted that the doctrine articulated by Justice Barbour in Miln was never used to limit federal power or to invalidate a congressional statute. See J. Schmidhauser, supra note 19 , at 62 .

${ }^{34}$ See, e.g., Cooley v. Board of Port Wardens, 53 U.S. (I2 How.) 299 (185I). See generally J. SchMidhaUSER, supra note 19 , at 63-64.

${ }^{35}$ U.S. Const. amend. XIII; see p. II43 infra.

${ }^{36}$ U.S. Const. amend. XIV; see pp. I144-46 infra.

${ }^{37}$ U.S. Const. amend. XV; see p. II47 infra. The post-Civil War amendments were the result of a special concern with racial discrimination, and the civil 
wrote into the Constitution broad new guarantees of liberty and equality by which the federal government committed itself to protecting citizens against states and private individuals. The five major civil rights acts ${ }^{38}$ undertook to elaborate these new liberties and to provide the means for their effective enforcement. Each act contained jurisdictional provisions conferring on the federal courts primary responsibility for the vindication of these liberties. $^{39}$ As a result of these and other acts the lower federal courts emerged from the Reconstruction period with significantly greater importance, supplanting the state courts as the principal forum for enforcing federal law. ${ }^{40}$

The overall shift in the balance of power between the federal and state governments, however, was moderate. ${ }^{41}$ The actions of state governments were limited by federal law, but the traditional police powers of the state remained largely undiminished. ${ }^{42}$ Indeed, the substantial increase in the activity of the federal government in response to the war and to the turbulent conditions in the South appears to have been aimed primarily at restoring the internal integrity of the states through ensuring the proper administration of justice and equal treatment of citizens rather than at replacing the states as the dominant actors in the federal system. ${ }^{43}$

rights powers they confer "are potentially the most far-reaching" of all the grants of power in the Constitution. See G. Gunther, Cases and Materials on Constitutional Law 899 (gth ed. 1975); cf. Fitzpatrick v. Bitzer, 427 U.S. 445 (I976) (enforcement powers under the fourteenth amendment limit the eleventh amendment and the principle of sovereign immunity); Jones v. Alfred H. Mayer Co., 392 U.S. 409 (1968) (Congress, acting under the thirteenth amendment, may reach private conduct).

${ }^{38}$ Act of April 9, 1866, ch. 31, 14 Stat. 27 (outlawing Southern Black Codes); Act of May 31, I870, ch. I4, I6 Stat. I40 (protecting voting rights); Act of Feb. 28, I87I, ch. 99, I6 Stat. 433 (protecting voting rights); Act of April 20, I87I, ch. 22, I7 Stat. I3 (suppressing the Ku Klux Klan); Act of March I, 1875, ch. II4, I8 Stat. 335 (prohibiting racial discrimination in public accommodations).

${ }^{39}$ See Wiecek, The Reconstruction of Federal Judicial Power, 1863-1875, I3 AM. J.L. Hist. 333 (I969).

${ }^{40}$ See, e.g., Schwartz, The Amendment in Operation: A Historical Overview, in The Fourteenth Amendment 29, 3i (B. Schwartz ed. I970).

${ }^{41} \mathrm{See} \mathrm{H}$. Hyman, supra note 6, at 531 (characterizing the resulting shift as a "moderate revolution"). See also Bickel, The Original Understanding and the Segregation Decision, 69 Harv. L. Rev. I, 59 (1955).

42 See, e.g., J. James, The Framing of the Fourteenth Amendment 201 - 02 (I956); P. Paludan, A Covenant with Death 5i-60 (i975); Graham, Our Declaratory Fourteenth Amendment, 7 Stan. L. Rev. 3, 3-39 (I954).

${ }^{43}$ See, e.g., Cong. Globe, 39th Cong., Ist Sess. 483 (1866) (remarks of Rep. Bingham) ("I have always believed that the protection in time of peace within the State of all the rights of person and citizen was one of the powers reserved to the States. And so I still believe."). See also Kelly, Comment, in New Frontiers of the American Reconstruction 55 (H. Hyman ed. ig66). 
The ratification of the thirteenth amendment in I 865 signaled the beginning of a period of constitutional upheaval designed to safeguard the rights of the recently emancipated slaves. This amendment, directed not only to the federal government, but also to states and to private individuals, abolished slavery and gave Congress the power to enforce its provisions through appropriate legislation. ${ }^{44}$ Most Congressmen assumed that the amendment would have far-reaching effects beyond the abolition of personal bondage and would provide the basis for guaranteeing the freedmen certain minimum rights. ${ }^{45}$ Indeed, the opponents of the amendment attacked it as an unconstitutional federal invasion of the rights of the states. ${ }^{46}$

It soon became apparent, however, that the thirteenth amendment alone could not achieve the Republican goal of equal treatment for the freedmen. Atrocities against emancipated blacks and Union sympathizers were widespread in the South, and the former Confederate states passed "Black Codes" which effectively reenslaved the freedmen. ${ }^{47}$ The Civil Rights Act of $1866^{48}$ and

${ }^{44}$ U.S. Const. amend. XIII provides:

Section I. Neither slavery nor involuntary servitude, except as a punishment for crime whereof the party shall have been duly convicted, shall exist within the United States or any place subject to their jurisdiction.

Section 2. Congress shall have power to enforce this article by appropriate legislation.

${ }^{45}$ See Howe, Federalism and Civil Rights, 77 Mass. Hist. Soc'y Proc. 15, 23-25 (1965).

${ }^{46}$ See, e.g., Cong. Globe, 38 th Cong., ist Sess. 1423 (1864) (remarks of Sen. Saulsbury).

${ }^{47}$ See P. Paludan, supra note 42 , at 215 ; J. Randall \& D. Donald, The Civil WAR AND ReCONSTRUCTION 57I-74 (I969).

${ }^{48}$ The 1866 Act secured to the freedmen the right to make and enforce contracts, to sue and be sued, to give evidence, and to own and transfer property. I4 Stat. 27 (codified at 42 U.S.C. $\$ \S$ I 98 I-I 982 (I970)). Although the draftsmen of the measure had asserted that it reflected their continuing concern for the preservation of states' rights, P. Paludan, supra note 42 , at $5 \mathrm{I}$, President Johnson vetoed the bill. He claimed that although the measure did not in fact exceed the constitutional prerogatives of the federal government, there was no principle sufficiently distinguishing the rights protected by the statute from interests beyond the competence of the federal government to prevent it from leading to an unconstitutional expansion of federal authority. See 8 J. Richardson, MesSages and Papers of the Presidents, I843-19i4, at 3596-6i i (I898). Although Rep. Bingham, author of the first section of the fourteenth amendment, also felt that the bill intruded on state prerogatives, see Cong. GLOBE, 39th Cong., Ist Sess. 438 (I866) (remarks of Rep. Bingham), the Act was passed over President Johnson's veto, with the assent of all but three Republicans in the Senate, J. Randall \& D. Donald, supra note 47 , at 579 . The assessment of the impact of the I 866 Act was varied. Sen. Saulsbury remarked that it was "one of the most dangerous bills that was ever introduced into the Senate of the United States," Cong. Globe, 39th Cong., Ist Sess. 476 (I866), whereas Sen. Trumbull, sponsor of the bill, belittled its scope, apparently believing that it was "not a tremendous constitutional broad jump, but only an a fortiori observation." Fairman, Does 
the Freedmen's Bureau Bill ${ }^{49}$ were enacted under the authority of the thirteenth amendment to do away with these practices. But the power of the Congress to pass the two acts was questioned, and two months later, in response to those challenges, the fourteenth amendment was adopted by Congress and submitted to the states for ratification. ${ }^{50}$

The fourteenth amendment was a product of radical idealism and political necessity. ${ }^{51}$ Although at the time it was heralded and denounced as working a fundamental change in the Constitution, ${ }^{52}$ the extent of that change was much debated both in I 868 and thereafter. ${ }^{53}$ A basic purpose of the amendment was to affirm the citizenship of the freedmen. ${ }^{54}$ In providing that all the Fourteenth Amendment Incorporate the Bill of Rights?, 2 Stan. L. REv. 5, I7 (1949). Compare Cong. Globe, 39th Cong., Ist Sess. 570 (I866) (remarks of Sen. Morril) ("I freely concede that it [the I866 Act] is revolutionary"), with id. at 504 (remarks of Sen. Howard) ("There is no invasion of the legitimate rights of the States.").

49 The Freedmen's Bureau was created pursuant to the Act of March 3, I865, ch. 90, I3 Stat. 507. With offices in every Southern state, the Bureau played an integral role in smoothing the transition from slavery to freedom for Southern blacks. The Bureau found employment for former slaves, established them on public lands under the homestead law, provided hospital services and schools, and, through its own system of special courts, sought to secure equal justice for the freedmen. See J. Randall \& D. Donald, supra note 47, at 576-77. In I866 moderate Republicans introduced a bill providing for the continued existence of the Bureau, extending its authority to refugees and freedmen throughout the country, and empowering it to provide military protection to victims of racial discrimination. Id. at 577. President Johnson vetoed the measure, id. at 577-78, thereby alienating many Republican moderates and pushing them towards support of a more radical program for Reconstruction.

${ }^{50}$ U.S. Const. amend. XIV. Section I provides:

All persons born or naturalized in the United States, and subject to the jurisdiction thereof, are citizens of the United States and of the State wherein they reside. No State shall make or enforce any law which shall abridge the privileges or immunities of citizens of the United States; nor shall any State deprive any person of life, liberty, or property without due process of law; nor deny to any person within its jurisdiction the equal protection of the laws.

${ }^{51}$ See, e.g., J. Randall \& D. Donald, supra note 47, at 580-8I, 633 .

52 See, e.g., Cong. Globe, 39th Cong., ist Sess. I27I (I866) (remarks of Rep. Kerr); $i d$. at I065 (remarks of Rep. Hale).

${ }^{53}$ Compare H. Hyman, supra note 6, at 465-70; Graham, supra note 42 , at I8-38; and Fairman, supra note 48, with J. JAMES, supra note 42 , at $\mathrm{I}_{5} \mathrm{I}-52$ and Gressman, The Unhappy History of Civil Rights Legislation, 50 MicH. L. Rev. I323, I328-33, I357-58 (I952).

54 The fourteenth amendment had at least the effect of overruling the holding in Dred Scott v. Sandford, 60 U.S. (I9 How.) 393 (1857), that blacks could not be citizens of the Untied States, id. at 404. See T. Cooley, A Treatise on ConStitutional Limitations 653-56 (ist ed. I868); Graham, supra note 42, at 23. Moreover, even commentators who have sought to deemphasize the amendment's intended impact on federal-state relations have acknowledged that adoption of the amendment was based in part on a desire to ensure the existence of a constitutional foundation for the rights of citizenship bestowed on freedmen by the Civil 
persons born or naturalized in the United States are "citizens of the United States and of the State wherein they reside," it created a national citizenship independent of that conferred by the states. $^{55}$ The amendment also created a federal guarantee for an ill-defined category of "privileges and immunities," possibly including the provisions of the Bill of Rights, which previously had been applied only to the federal government. ${ }^{56}$

This uncertainty as to the reach of the privileges and immunities clause heightens the difficulty of determining the intended impact of the amendment on federal-state relations in the civil rights area. Although it has been argued that the amendment represented a complete reversal of ante bellum attitudes and an affirmation of plenary federal power to safeguard individual rights, ${ }^{57}$ this interpretation may go too far. The Congress which adopted the amendment was essentially conservative, ${ }^{58}$. and more radical provisions, which authorized the federal government to secure equal treatment of blacks by private parties and specifically granted blacks the right to vote, were rejected. ${ }^{59}$

Rights Act of 1866 . See, e.g., Bickel, supra note 4I, at 6I; J. JAMEs, supra note 42, at 179; Royall, The Fourteenth Amendment: The Slaughterhouse Cases, 4 S.L. REv. 558, 574 (I878).

${ }^{55}$ See, e.g., Cong. GLobe, $42 \mathrm{~d}$ Cong., Ist Sess. app., at 67,69 (1871) (remarks of Rep. Shellabarger).

${ }^{56}$ Before the Civil War, the Supreme Court had held that the guarantees of the Bill of Rights served only to limit the actions of the federal government, not state governments. Barron v. Mayor of Baltimore, 32 U.S. (7 Pet.) 243 (I833). Although the fourteenth amendment clearly was designed to provide federal protection against state deprivation of certain rights, whether that protection was intended to be limited to "fundamental" matters - rights essential to "fundamental principles of liberty or justice" - or to "incorporate" or "absorb" all of the Bill of Rights guarantees and make them applicable to the states has been the subject of major debate among judges and commentators. Compare Duncan v. Louisiana, 391 U.S. I45, I73-78 (r968) (Harlan, J., dissenting); Adamson v. California, 332 U.S. 46, 59, 62-67 (I947) (Frankfurter, J., concurring); Palko v. Connecticut, 302 U.S. 319, 322-28 (I937) (Cardozo, J.); and Fairman, supra note 48, with Duncan v. Louisiana, 39I U.S. I45, I62-7I (I968) (Black \& Douglas, JJ., concurring); Adamson v. California, 332 U.S. 46, 69-123 (I947) (Black, J., dissenting); and I. Brant, The BILL of Rights 315-45 (I965). See generally Henkin, "Selective Incorporation" in the Fourteenth Amendment, 73 Yale L.J. 74 (1963); Kadish, Methodology and Criteria in Due Process Adjudication - $A$ Survey and Criticism, 66 YaLE L.J. 319 (1958).

${ }^{57}$ See, e.g., H. Meyer, The Amendment That Refused to Die at xi (1973); I. BRANT, supra note 56; Gressman, supra note 53 , at $1332-33$.

${ }^{58}$ See J. Randall \& D. Donald, supra note 47 , at $580-85$; J. JAmes, supra note 42 , at $15 \mathrm{I}-52$.

${ }^{59}$ The failure of Congress to provide explicitly for suffrage for blacks in the fourteenth amendment has been interpreted as evidence of the conservatism, or at least the cautiousness, of the Republicans who drafted the amendment. See, e.g., P. Paludan, supra note 42 , at 49-52; K. Stampp, The Era of Reconstruction, I865-I877, at $14 \mathrm{I}-42$ ( 1965$)$. 
Indeed, the amendment as adopted created no new substantive civil rights. Rather, in accord with traditional notions of federalism, the amendment simply required the states to grant equally to all citizens whatever rights they saw fit to establish. ${ }^{60}$ Thus, the states retained power to define their obligations to citizens and to determine the procedures and remedies available for the vindication of these rights.

Despite its relative moderation, the Southern states refused to ratify the amendment. ${ }^{61}$ In response, Congress in 1867 instituted Military Reconstruction. ${ }^{62}$ The freedmen were given the franchise, which was denied to the former secessionists. State conventions chosen by this new electorate framed constitutions amenable to Congress, ratified the fourteenth amendment, and

The so-called "Bingham Amendment," proposed to the Joint Committee on Reconstruction on February 3, I866, by Rep. John A. Bingham of Ohio, would have gone further than the amendment ultimately passed. Bingham's proposal would have given Congress the power to secure the civil rights of the freedmen. Bingham's amendment read:

The Congress shall have power to make all laws which shall be necessary and proper to secure to the citizens of each State all privileges and immunities of citizens in the several States [article IV, § 2], and to all persons in the several States equal protection in the rights of life, liberty, and property [fifth amendment].

Cong. Globe, 39th Cong., Ist Sess. I034 (I866); see J. James, supra note 42, at 82. The Bingham Amendment was criticized as "the embodiment of centralization and the disenfranchisement of the States of those sacred and immutable states' rights," Cong. GLOBE, 39th Cong., Ist Sess. app., at 133 (1866) (remarks of Rep. Rogers), and its rejection has been seen as evidence of the moderate goals of Congress. See, e.g., Cong. Globe, 42d Cong., Ist Sess. app., at 15I-52 (187I) (remarks of Rep. Garfield); J. James, supra note 42 , at 87 ; P. Paludan, supra note 42 , at $5 \mathrm{I}-52$

${ }^{60}$ See, e.g., H. Hyman, supra note 6 , at $467-68$; J. JAMEs, supra note 42 , at 179-80. But see Graham, supra note 42 , at 18-20, 37-39.

${ }^{61}$ See J. Randall \& D. Donald, supra note 47 , at 584-85.

${ }^{62}$ On the view that lawful government had ceased to exist in the seceded states and that those states could be governed by Congress, the Act of March 2, 1867 - supplemented by the Acts of March 23 and July 19, 1867, and March II, I868 - decreed temporary military rule and a drastic reorganization of Southern state governments. The states deemed unreconstructed - all the former members of the Confederacy except Tennessee - were divided into five military districts under federal commanders, empowered to arrest, conduct military trials, remove civilian officeholders, and use federal troops to preserve order. See J. Randall \& D. Donald, supra note 47 , at 565 . The district commanders were also given responsibility for implementing the program of political reconstruction, including the enrollment of black voters and the supervision of the drafting of new state constitutions.

By 1868 , six of the Southern states had completed the Reconstruction process and were readmitted. Four states - Virginia, Georgia, Mississippi, and Texas delayed until after the fourteenth amendment had been ratified and the fifteenth amendment adopted by a vote of Congress. They therefore were required to ratify the fifteenth amendment as well. See id. at 595-600,619; K. Stampp, supra note 59 , at $144-45$. 
thereby gained readmission to the Union. ${ }^{63}$ Continuing Southern resistance to military rule and black suffrage, however, necessitated further congressional action.

The fifteenth amendment, prohibiting denial of the right to vote on the basis of race or previous condition of servitude, was adopted in $1870 .{ }^{64}$ The amendment represented a significant departure from ante bellum federalism, which had given the states exclusive control over voting qualifications, ${ }^{65}$ but like the fourteenth amendment, it may best be seen as a compromise between civil liberties and states' rights. In enacting the fifteenth amendment, Congress considered three possible provisions. The most radical would have given the federal government complete control over the right to vote. A slightly more moderate proposal would have left control of the franchise in state hands while proscribing certain conditions, such as race or literacy requirements. The measure as passed was even more moderate, precluding only the explicit use of racial criteria as voting qualifications. ${ }^{66}$

2. The Expansion of Federal Jurisdiction. - The years following the outbreak of the Civil War witnessed the greatest expansion of federal court jurisdiction since $I 789 .{ }^{67}$ In a series of enactments ${ }^{68}$ Congress broadened the scope of federal judicial authority, largely at the expense of the states. Federal removal jurisdiction was expanded; the habeas corpus powers of the lower federal courts were significantly increased; and each of the major civil rights acts specifically guaranteed access to the federal

${ }^{63}$ See id. Congressional rejection of radical Republican efforts to subject the reconstructed states to "fundamental conditions" - requirements to be placed in the states' constitutions barring future constitutional amendments which would disenfranchise blacks or enfranchise former Confederate officials - has been seen as further evidence of the relatively moderate spirit of the Republican Congress at this time. See M. Benedict, A Compromise of Principle 315-25 (i974).

${ }^{64}$ U.S. Const. amend. XV provides:

Section I. The right of citizens of the United States to vote shall not be denied or abridged by the United States or by any State on account of race, color, or previous condition of servitude.

Section 2. The Congress shall have power to enforce this article by appropriate legislation.

${ }^{65}$ See H. Hyman, supra note 6, at 425.

${ }^{66}$ See P. Paludan, supra note 42 , at 52. See also M. Benedict, supra note 63, at $325-36$.

${ }^{67}$ See generally F. Frankfurter \& J. Landis, The Business of the Supreme Court 6i-65 (i927); S. Kutler, Judicial Power and Reconstruction Politics 143-60 (1968); Wiecek, supra note 39 , at 333 .

${ }^{68}$ Congress acted primarily out of concern for the war effort and the interests of the freedmen, but the legislative expansion of federal court jurisdiction also reflected an awareness of the need for national regulation of an increasingly national economy. See F. Frankfurter \& J. Landis, supra note 67, at 6I-64; Wiecek, supra note 39 , at $333-34,358$. 
courts. Finally, in the Act of 1875 the federal courts were granted jurisdiction over all federal question cases.

During the Reconstruction period the removal legislation was the most important source of new federal judicial power ${ }^{69}$ Prior to the war federal removal jurisdiction had been restricted to a limited class of diversity cases ${ }^{70}$ and to actions against federal customs officials. ${ }^{71}$ The Act of March 3, 1863, began the expansion of this jurisdiction by providing for the removal of all criminal and civil suits brought against federal officers for acts committed during the rebellion allegedly under the authority of Congress or the President. ${ }^{72}$ Congress subsequently amended the I 863 Act to void all proceedings in state courts brought after the removal of the original action, ${ }^{73}$ and enacted additional statutes permitting removal in cases brought against federal officers enforcing the wartime revenue and conscription acts. ${ }^{74}$ The right of federal removal was extended to private citizens by measures, adopted for the benefit of the freedmen, providing for removal of cases alleging state official interference with civil rights. ${ }^{75}$

The Habeas Corpus Act of $1867^{76}$ was the source of the second major expansion of federal judicial power. The statute

${ }^{69}$ See S. KUTLER, supra note 67, at I43; Wiecek, supra note 39 , at 336-42.

${ }^{70}$ Act of Sept. 24, I78a, ch. 20, § I2, I Stat. 79 (First Judiciary Act).

${ }^{71}$ See, e.g., Act of March 3, I8I5, ch. 94, $\S 6,3$ Stat. 233; Act of March 2, I833, ch. $57, \S 3,4$ Stat. 633 (current versions at 28 U.S.C. § I442 (1970)). As was the case with the subsequent Civil War removal legislation, these early enactments were designed to protect federal officers who were being subjected to suit in state courts because of their role in enforcing unpopular national policies. The I8I5 Act was designed to protect federal customs officers who were being harassed by New England shipowners protesting the War of I8I2. The I833 removal provision was part of the Force Act, designed to defeat South Carolina's resistance to the enforcement of the federal revenue laws. Section 3 of the Act permitted removal of suits involving "any right, authority, or title" under any federal revenue statute. See generally S. KUTLER, supra note 67, at 145-46; Amsterdam, Criminal Prosecutions Affecting Federally Guaranteed Civil Rights: Federal Removal and Habeas Corpus Jurisdiction to Abort State Court Trial, II 3 U. PA. L. REv. 793, 806-07 (I965). Although the statutes were infrequently used, the Removal Acts of $18 \mathrm{I}_{5}$ and $\mathrm{I} 833$ have been praised as a "milestone in the development of inferior federal courts" because they marked the first recognition that the lower federal courts had an important role to play in enforcing national policies. Hufstedler, Comity and the Constitution: The Changing Role of the Federal Judiciary, 47 N.Y.U. L. REv. 84I, 843-44 (1972).

${ }^{72}$ Act of March 3, r863, ch. 8I, § 5, I2 Stat. 756.

${ }^{73}$ Act of May II, I866, ch. 80, $\$ 3$, I4 Stat. 46.

${ }^{74}$ Act of July I3, I866, ch. I84, § 67, I4 Stat. I71.

${ }^{75}$ Act of April 9, 1866, ch. 3 I, § 3, I4 Stat. 27. The I866 civil rights removal provision is the progenitor of the current 28 U.S.C. $\S$ I443 (1970). See also Voting Rights Enforcement Act of I87 I, ch. 99, §§ I5, I6, I6 Stat. 438 (repealed I894).

${ }^{76}$ Act of Feb. 5, 1867, ch. $28, \S$ I, I4 Stat. 385 (current version at 28 U.S.C. $\S 224 \mathrm{I}(\mathrm{c})(3)(\mathrm{I} 970))$. 
not only broadened the power of the federal courts, but also essentially altered the nature of the habeas writ itself. Before 1867 habeas corpus served principally as a means of testing the legality of confinements imposed by the executive, and was unavailable to individuals confined by the judgments of jurisdictionally competent courts. ${ }^{77}$ After the 1867 Act the writ became a means of challenging judicial decisions of constitutional questions. The result was a shift of power to the lower federal courts, who for the first time were given authority to review the judgments of state courts, even after they had been affirmed by state supreme courts. ${ }^{78}$ Although subsequently reduced in scope by the Supreme Court's formulation of an exhaustion requirement ${ }^{79}$ the 1867 Act, which, like the postwar removal statute, had been prompted by Republican concern for the plight of Southern freedmen ${ }^{80}$ represented an effort in the habeas corpus context to extend federal court jurisdiction to its constitutional limit. ${ }^{81}$

The third new source of judicial power stemmed from the Reconstruction civil rights acts themselves. The Civil Rights Act of 1870 created federal jurisdiction over suits alleging racially inspired interference with the franchise; ${ }^{82}$ the Act of $187 \mathrm{I}-$ embodying the current 42 U.S.C. $\S$ I 983 - provided a broad civil rights jurisdiction for all claims of deprivations of federally secured rights "under color of" state law; ${ }^{83}$ and the Civil Rights Act of 1875 , assuring blacks equal access to places of public accommodations, granted jurisdiction to the federal trial courts to enforce its provisions. ${ }^{84}$ Finally, the Judiciary Act of $1875^{85}$ created general federal question jurisdiction in civil actions, thereby providing a federal trial forum for every litigant engaged in a substantial civil controversy based on a claim arising under the Federal Constitution and laws.

${ }^{77}$ See Wiecek, supra note 39 , at 344.

${ }^{78}$ The 1867 Act extended the federal habeas power to "all cases where any person may be restrained of his or her liberty in violation of the Constitution or of any treaty or law of the United States ....." See also H. Hyman, supra note 6, at 473-75; Developments in the Law-Federal Habeas Corpus, 83 Harv. L. REv. 1038, 1048 (1970).

${ }^{79}$ See Ex parte Royall, II7 U.S. 24I (1886). See generally Amsterdam, supra note $7 \mathrm{I}$, at $882-908$.

${ }^{80}$ See Wiecek, supra note 39 , at 344 .

${ }^{81}$ See Cong. Globe, 39th Cong., Ist Sess. 4I5I (1866) (remarks of Rep. Lawrence).

82 Act of May 31, I870, ch. II4, § 8, I6 Stat. I42.

${ }^{83}$ Act of April 20, I87I, ch. 22, § I, I7 Stat. I3. The portions of the Act creating the cause of action are currently codified as 42 U.S.C. $\S$ I983 (I970); the Act's jurisdictional grant was the forerunner of the present 28 U.S.C. $\$$ I343 (3) (1970).

${ }^{84}$ Act of March I, I875, ch. II4, § 3, I8 Stat. 335 .

${ }^{85}$ Act of March 3, I875, ch. I37, $\$$ I-2, I8 Stat. 470. 
This significant expansion of federal judicial power seems to reflect both the Republicans' belief that the judiciary was the most appropriate institution to effectuate their "moderate revolution" in civil rights ${ }^{86}$ and their increasing distrust of the willingness of state judges to enforce vigorously national laws or fulfill national policies. Rather than providing for a large-scale displacement of state police power by congressional regulation of intrastate affairs, the Republicans sought to create in the federal courts opportunities for litigants - primarily the freedmen and federal officers enforcing war-related and civil rights laws - to invoke the power of the national government to safeguard nationally secured liberties threatened by the action or inaction of the states.

The Republican antipathy to state courts is, at first glance, somewhat surprising. From the Judiciary Act of 1789 on, access to the lower federal courts had been largely restricted to citizens exposed to the possible prejudices of tribunals of foreign states. The prevailing assumption had been that the state courts were the appropriate forum for the enforcement of federal law. ${ }^{87}$ Moreover, in the two decades immediately preceding the outbreak of the war, the Republicans, in their efforts to undermine the fugitive slave laws, had championed the cause of the state courts and argued for the rights of the states to impair enforcement of the fugitive slave clause by state court action and the use of state judicial process, particularly the writ of habeas corpus. ${ }^{88}$ It had been the role of Chief Justice Taney and the slaveholders to affirm the supremacy of the national government within its legitimate sphere and to invalidate state efforts to circumvent or thwart the federal judiciary. ${ }^{89}$

During the course of the war, however, the Republicans became progressively alienated from the state courts. In many border states and in the occupied South, judges and prosecutors unsympathetic to the Republicans and the Union sought to impede the war effort. Civil and criminal suits were brought in state courts charging the national officials attempting to enforce the conscription, revenue, and antidisloyalty laws with violations of state laws against unlawful seizure, false arrest, kidnapping, assault and battery, libel and slander. ${ }^{90}$ State judges issued writs

\footnotetext{
${ }^{86}$ See pp. I I45-47 supra.

${ }^{87} \mathrm{See}$, e.g., F. Frankfurter \& J. LANdis, supra note 67 , at 65; P. Bator, P. Mishinin, D. Shapiro \& H. Wechsler, Hart \& Wechsler's The Federal Courts and the Federal System 33-35, 844-45 (2d ed. I973) [hereinafter cited as HART AND WechsLer].

${ }^{88}$ See Neuborne, The Myth of Parity, 90 HaRv. L. Rev. II05, IIII-I4 (I977).

${ }^{89} \mathrm{See}$ Ableman v. Booth, 62 U.S. (2I How.) 509 (1859); Neuborne, supra note 88 , at IIII-I4.

${ }^{90}$ See H. Hyman, supra note 6, at 249; Wiecek, supra note 39 , at 338.
} 
of habeas corpus to release individuals confined by national military and civilian officers, and, when national officers persisted in arrests and imprisonments in defiance of state writs, state court contempt citations were issued against them. Noncomplying national officials - ranging from Cabinet secretaries to army lieutenants - faced fines and prison terms in addition to civil penalties in private actions. ${ }^{91}$ The 1863 removal statute and later amendments appear to be a direct response to the plight of such national officers left "naked in the interstices of federalism." 92

Hostility toward state courts also appeared to be linked with racial attitudes. In the ante bellum period, Southern state courts had barred blacks from testifying, limited their right to sue, and excluded them from service on juries, while Democrats continued their efforts to keep blacks wholly subject to state laws and courts. ${ }^{93}$ The state courts as then constituted thus appeared unlikely to accomplish the Republican goal of equality before the law, and the reform required to avoid placing primary reliance on the national courts might well have seemed not simply unnecessary but unachievable. ${ }^{94}$

An additional factor reinforcing the Republican distrust of state courts may have been their generally poor performance in nonracial or war-related matters. In the north and west, state courts, reflecting the popular sentiments, upheld unorthodox fiscal behavior by local governments. ${ }^{95} \mathrm{~A}$ number of western states, under the influence of the Granger movement, adopted legislation regulating private enterprise which, to the horror of the eastern conservative Republicans who dominated the party, the state courts sustained against attack. ${ }^{96}$ Even in the northeast, the decreasing quality of urban politics, as manifested by the New York City election frauds of 1868 , was attributed to the inade-

${ }^{91}$ See H. Hyman, supra note 6, at 240-41.

92 Id.

${ }^{93}$ Id. at 273 .

${ }^{94}$ See Wiecek, supra note 39 , at 338 .

${ }^{95} \mathrm{See}$, e.g., H. Hyman, supra note 6, at 229-33. The most notorious contemporary instance of state court capitulation to local pressures was the Iowa litigation culminating in Gelpcke v. City of Dubuque, 68 U.S. (I Wall.) I75 (I864). The city of Dubuque, in an effort to attract a railroad to construct a line from Dubuque into the interior of the state, had the Iowa legislature adopt special legislation exempting it from the state constitutional limitation on municipal indebtedness, but then attempted to evade its obligation to pay its creditors by contending that the act authorizing the issuance of the bonds was unconstitutional. See id. at 202-05. The state supreme court bowed to public pressure and sustained the city's position. See State v. County of Wapello, I3 Iowa 388 (1862). The United States Supreme Court reversed, finding that the state court invalidation of the bondenabling legislation violated the contracts clause. 68 U.S. (I Wall.) at 206-07.

${ }^{86}$ See H. Hyman, supra note 6, at 359-6r. See also Wiecek, supra note 39 , at 358. 
quate monitoring of the political process by the state courts. ${ }^{97}$ Thus, throughout the Civil War and Reconstruction period state judiciaries often appeared unable or unwilling to withstand local popular pressures, and national policies, particularly equal treatment for blacks and economic conservatism, were seen as likely to suffer if primary reliance was placed on the state courts for their enforcement.

While the Republicans thus were unlikely to entrust the implementation of their Reconstruction program to the state courts, that program essentially involved judicial enforcement of federal equal rights laws. Apart from the temporary imposition of Military Reconstruction ${ }^{98}$ the Republicans generally eschewed efforts to alter the prewar allocation of substantive lawmaking between the nation and the states or to involve the national government in the administration of internal state affairs. This belief in no more than a moderate restructuring of the federal system was reinforced by a basic conservative nineteenth-century antipathy to government spending or the expansion of government bureaucracies. ${ }^{99}$ Thus, instead of adopting measures or requiring the states affirmatively to improve the social and economic status of blacks, ${ }^{100}$ the Republicans limited the federal interest to the provision of equality before the law and restricted the federal role to the correction of individual violations as they were raised in case-by-case litigation. The judiciary - inexpensive, nonbureaucratic, and traditionally conservative ${ }^{101}$ — was the most suitable agency for the enforcement of the Republicans' limited goals. And given the unreliable behavior of the state courts during the war and their evident susceptibility to local pressures,

${ }^{97}$ It has been suggested that conservative Republican concern about urban political corruption may have played a role in generating Northern support for the adoption of the fifteenth amendment. See H. Hyman, supra note 6, at 523-26.

${ }^{98}$ See pp. I1 $46-47$ \& notes 62-63 supra.

${ }^{99}$ See H. Hyman, supra note 6, at $227-29$.

100 The three basic elements of the abolitionist platform for securing true equality for the freedmen in the postwar South were the ballot, free public education, and land reform through the confiscation of the ante bellum plantations and estates and redistribution of the land by the federal government. Only the right to vote was even theoretically secured; the provision of education was half-heartedly pursued, while land reform proposals were repeatedly rejected. The Republican decision to provide only for equal political rights without attempting to give the former slaves the economic support necessary to make political equality meaningful and longlasting suggests the essentially conservative character of the party even during the so-called Radical Reconstruction and indicates the relatively diminished influence of the abolitionists and more radical egalitarians and nationalists. See generally J. McPherson, The Struggre for EQUALITy 386-4I7 (I964); K. STAMPP, supra note 59, at I26-3I.

${ }^{101}$ See generally S. Kutler, supra note 67, at 167-68; P. PALUdAN, supra note 42 , at 232-33; Wiecek, supra note 39 , at 357-59. 
the courts that the Republicans turned to were the federal trial courts.

3. The Act of 1871 . - Shortly after the ratification of the fifteenth amendment, Congress passed the Civil Rights Act of I $870^{102}$ - popularly known as the Force Act - which reenacted the Civil Rights Act of 1866 and provided for the use of federal troops to police the polls in the South. ${ }^{103}$ Nevertheless, Southern resistance to Reconstruction continued and by early $\mathrm{I} 87 \mathrm{I}$ there was overwhelming evidence that through tacit complicity and deliberate inactivity, state and local officials were fostering vigilante terrorism against politically active blacks and Union sympathizers. ${ }^{104}$ To remedy this situation required a further shift in the federal-state balance towards a greater, although still limited, national role in the internal operations of the states. Until I87I the Reconstruction measures had largely been concerned with affirmative state activities against blacks. Atrocities committed by the $\mathrm{Ku}$ Klux Klan, however, led Congress in the Act of $187 \mathrm{I}$ to provide civil rights protection against official inaction and the toleration of private lawlessness. ${ }^{105}$ On March 23, I 87I, President Grant requested emergency legislation in a special message, stating that a virtual state of anarchy existed in the South and affirming that the states were powerless to control the widespread violence. $^{106}$ In response, Congress enacted the Act of April 20, 187r. ${ }^{107}$

${ }^{102}$ Ch. II4, I6 Stat. I40 (1870).

${ }^{103} I d$. $\S 3$, I0.

${ }^{104}$ Organized terrorism in the Reconstruction South has popularly been associated with the Ku Klux Klan, founded in Tennessee in I866. See, e.g., Shapo, Constitutional Tort: Monroe v. Pape and the Frontiers Beyond, 60 Nw. U.L. Rev. 277, 279-80 (1965). The Klan was one of many such organizations, and drew its membership chiefly, although not solely, from the poor whites and yeoman farmers. See K. Stampp, supra note 59, at 199. Klansmen broke up Republican meetings, threatened radical leaders, whipped blacks, and drove black voters from the polls. "They were guilty of shootings, murders, and plundering, until their lawlessness caused Klan leaders themselves to try, unsuccessfully [in I869], to disband the organization." Id. at 200. See generally D. Chalmers, Hooded Americanism: The History of the Ku Klux Klan (1965).

${ }^{105}$ See, e.g., Cong. GLobe, $42 \mathrm{~d}$ Cong., Ist Sess. app., at 375 (1871) (remarks of Rep. Lowe) ("It is said that the states are not doing the objectionable acts. This argument is more specious than real .... What practical security would this provision give if it could do no more than to abrogate and nullify overt acts and legislation of a State?").

${ }^{106}$ President Grant's message requesting legislation to suppress the Klan read in pertinent part:

A condition of affairs now exists in some of the states of the Union rendering life and property insecure, and the carrying of the mails and collection of the revenue dangerous.... That the power to correct these evils is beyond the control of state authorities I do not doubt; that the power of the Executive of the United States, acting within the limits of the existing laws is sufficient for present emergencies is not clear.

Cong. Globe, 42d Cong., ist Sess. 299 (I87I).

${ }^{107}$ Ch. 22, I7 Stat. I3 (I87I). 
That the draftsmen of the measure were primarily concerned with suppressing the Klan is suggested by their repeated reference to its depredations. White vigilantes were described as having whipped, robbed, and murdered blacks. ${ }^{108}$ Representative Cobb of North Carolina, for example, spoke of the "social and political disability" imposed on blacks and white Republicans by "violence and lawlessness"; 109 Representative Coburn of Indiana emphasized that it was not the commission of "isolated outrages" which was the cause of national concern, but rather "crimes perpetrated by concert and agreement, by men in large numbers acting with a common purpose for the injury of a certain class of citizens entertaining certain political principles." 110 The legislators who proposed the bill saw themselves confronted not with common felonies but with a concerted plan of organized violence. ${ }^{111}$

Moreover, most Congressmen viewed the situation in the South as exacerbated by the inaction of the state and local governments. A full reading of the debates compels the conclusion that the Act was aimed at least as much at the abdication of law enforcement responsibilities by Southern officials as it was at the Klan's outrages. ${ }^{112}$ Thus, Representative, later President, Garfield of Ohio asserted that the problem in the South was not unequal laws, "but that even where the laws are just and equal on their face, yet, by a systematic maladministration of them, or a neglect or refusal to enforce their provisions, a portion of the people are denied equal protection ...." 113 Other legislators noted that members of the Klan were virtually immune from prosecution for

${ }^{108}$ See generally Cong. GLOBE, $42 \mathrm{~d}$ Cong., ist Sess. 153-57, 198-202, 236-40 (1871) (detailing the outrages perpetrated by the Klan). The Klan's misdeeds were the subject of a voluminous report to Congress. S. REP. No. I, $42 \mathrm{~d}$ Cong., ist Sess. (1871). See also Cong. Globe, $42 \mathrm{~d}$ Cong., ist Sess. 374 (1871) (remarks of Rep. Lowe) ("While murder is stalking abroad in disguise, while whippings and lynchings and banishments have been visited on unoffending American citizens, the local administrations have been found inadequate or unwilling to apply the proper corrective.").

${ }^{109}$ Cong. Globe, 42 d Cong., ist Sess. 439 (1871).

${ }^{110} I d$. at 457 .

${ }^{111}$ See, e.g., id. at 519 (remarks of Rep. Shellabarger).

${ }^{112} \mathrm{See}$, e.g., id. at 429 (remarks of Rep. Beatty) ("the remedy is needed because of prejudiced judges and juries"); id. at 394 (remarks of Rep. Rainey) ("the courts are in many instances under the control of those who are wholly inimical to the impartial administration of law and equity"); id. app., at I86 (remarks of Rep. Platt) (the judges exercised their "almost despotic powers . . . against Republicans without regard to law or justice.").

${ }^{113}$ Id. app., at $\mathrm{I} 53$. 
acts committed in pursuance of Klan orders, and that the state courts were largely subject to Klan domination. ${ }^{114}$

Although the proposed Ku Klux Klan Act was the subject of a heated debate, section I - which is today codified as $\mathbf{4 2}$ U.S.C. $\S 1983$ - was the least controversial portion of the bill. ${ }^{115}$ Far greater attention was focused on the provisions imposing criminal and civil penalties for conspiracies to deprive of constitutional rights, disqualifying former Confederates from serving as jurors, and empowering the President to suspend the writ of habeas corpus and use armed forces to suppress "insurrection." 116 Section I caused the least concern, as it only added civil remedies to the criminal penalties established by the 1866 Civil Rights Act. ${ }^{117}$

The constitutional debate on the I87 I Civil Rights Act focused on the scope of congressional authority to protect constitutional rights and to reach private conduct. In attempting to give meaning to the "privileges and immunities" which the federal government could secure, the legislators frequently adverted ${ }^{118}$ to Justice Washington's 1823 opinion in Corfield v. Coryell. ${ }^{119}$ Justice Washington had suggested that the privileges and immunities safeguarded by article IV comprehended "the enjoyment of life and liberty, with the right to acquire and possess property of every kind, and to pursue and obtain happiness and safety." ${ }^{120}$ The language of this opinion was broad, but its import was unclear. It did not directly confront the question whether article IV guaranteed substantive rights or only equality of enjoyment of such rights as the several states chose to extend to their citizens. ${ }^{121}$ Justice Washington's remarks were cited for both these interpretations, and the confidence with which Congressmen

${ }^{114}$ Id. app., at $\mathrm{I} 72$ (remarks on Sen. Pool) ("[No member of the Klan] has ever feared any punishment for a crime committed in pursuance of the orders of the Klan ... ."); id. at 653 (remarks of Sen. Osborn) ("The state courts, mainly under the influence of this [Klan] oath, are utterly powerless.").

${ }^{115} \mathrm{See}$, e.g., id. at 824 (remarks of Sen. Thurman); id. app., at 68 (remarks of Rep. Shellabarger). See also Gressman, supra note 53, at 1334; Shapo, supra note 104, at 279 \& n.II; Note, Limiting the Section 1983 Action in the Wake of Monroe v. Pape, 82 Harv. L. Rev. I486, 1488 \& n.I4 (I969).

${ }^{116}$ Ch. 22, \$§ 2-5, I7 Stat. I3 (187I); see Cong. Globe $42 \mathrm{~d}$ Cong., Ist Sess. app., at 220 (1871) (remarks of Sen. Thurman).

${ }^{117} \mathrm{See}$ Cong. Globe, $42 \mathrm{~d}$ Cong., Ist Sess. app., at 68 (remarks of Rep. Shellabarger).

${ }^{118}$ See Graham, supra note 42 , at $36-37$. See also P. Paludan, supra note $4^{2}$, at 268 n. 37 .

1196 F. Cas. 546 (C.C.E.D. Pa. I823) (No. 3,730). Justice Washington's interpretation of the scope of "privileges and immunities" was much cited by members of Congress throughout the Reconstruction period. See Fairman, supra note 48 , at $9-17$.

${ }^{120} 6 \mathrm{~F}$. Cas. at $55 \mathrm{I}-52$.

${ }^{121}$ See Fairman, supra note 48 , at 9-13. 
in $187 \mathrm{I}$ relied upon the case suggests that they did not appreciate the ambiguities involved. ${ }^{122}$

An expansive interpretation of the $187 \mathrm{I}$ Civil Rights Act seems improbable in the light of the political atmosphere in which the measure was passed. The Radicals controlled neither the Congress nor the country at large, and the framers of the Ku Klux Klan Act were quick, both by argument and amendment, to reconcile the statute with prevailing notions of states' rights. ${ }^{123}$ The more intrusive provisions of the Act were viewed as necessary responses to the outrages of the Klan, not foundations for establishing the strong central government advocated by the Radicals. Thus, while the Act was intended to remedy the deficiencies of the Southern states, there is little indication in the debates that Congress sought to impair their political independence. ${ }^{124}$

\section{The Era of "Dual Federalism"}

I. Civil Rights Enforcement. - The vagueness of the language of the Civil Rights Act left the courts - perhaps intentionally with broad latitude to construe these provisions. In the immediate post-Reconstruction years, this legislation was progressively eviscerated by restrictive interpretations of the interests the federal government was empowered to protect, and of the range of conduct it could prohibit consistent with the fourteenth amendment. In reaching such conclusions, the Court seemed to disregard the "original understanding" of Congress. ${ }^{125}$ But the nation at large, apprehensive over the expansion of the federal government and increasingly apathetic to the plight of the freedmen, appeared to support the Supreme Court's hostility to the Reconstruction legislation. ${ }^{126}$

${ }^{122}$ See id. at $12, \mathrm{I} 7$. Compare The Slaughterhouse Cases, 83 U.S. (I6 Wall.) 36, 75-76 (1873) (Miller, J.), with id. at 97-98 (Field, J., dissenting).

${ }^{123}$ See, e.g., Cong. Globe, 42d Cong., Ist Sess. 697-98 (I87I) (remarks of Sen. Edmunds).

${ }^{124}$ See H. Hyman, supra note 6 , at 530-31; P. Paludan, supra note 42 , at 239-42, 245-47.

${ }^{125}$ The report of The Slaughterhouse Cases, 83 U.S. (I6 Wall.) 36 (I873), printed in United States Reports, indicates that neither the counsel who argued the case nor most of the Justices who heard it consulted the proceedings and debates of the Congress which adopted the amendment. See Royall, supra note 54, at 563 (1878). See generally C. Coldins, The Fourteenth Amendment and the States (I9I3).

${ }^{126}$ See, e.g., M. Berger, EQuality By Statute 63 (rev. ed. 1967); Frank \& Munro, The Original Understanding of the Equal Protection of the Laws, 50 Colum. L. Rev. I3I, I50 (1950). One newspaper praised the Slaughterhouse decision as a necessary "check upon the centralizing tendencies of the Government, and upon the determination of the Administration to enforce its policy and to maintain its power even at the expense of the Constitutional prerogatives of the States." Chicago Daily Tribune, April I9, 1873, at 4, col. 3. 
Soon after the Civil War, the Supreme Court signaled its intention to return to the states the primary role in the area of civil liberties. ${ }^{127}$ In the Slaughterhouse Cases, ${ }^{128}$ one of the leading decisions vindicating traditional notions of dual federalism, the Court rejected the contention of Louisiana butchers that a state-created monopoly in slaughtering, which denied them their livelihood, violated the fourteenth amendment's privileges and immunities and due process clauses. ${ }^{129}$ Justice Miller limited the interests protected by the amendment to only those rights correlative to the existence of national government, ${ }^{130}$ effectively

${ }^{127}$ Two early post-Civil War decisions indicating that the Supreme Court was anxious to preserve a considerable degree of autonomy for the states are Texas v. White, 74 U.S. (7 Wall.) 700 (1869), and Collector v. Day, 78 U.S. (II Wall.) I13 (1871). In White, Texas filed a bill in equity in the Supreme Court against citizens of other states, seeking to enjoin payment of bonds originally issued by the United States to Texas as part of a border dispute settlement. Part of the issue had remained in the state treasury when the Civil War erupted, and the Confederate state legislature had authorized their disposition and sale to defray the costs of the war. In determining a crucial jurisdictional question whether or not Texas, which had not yet been readmitted to the Union by Congress, was a state - the Court essentially affirmed the basic premises of Republican Reconstruction policy that the seceded states and their people were out of their proper relation to the Union and that their reconstruction constituted a political question to be resolved by the legislative, not the judicial, branch of the national government, 74 U.S. (7 Wall.) at 719-21, 725-30. In so doing, however, the Court used rhetoric strongly affirming the significance of autonomous states: "[T]he preservation of the States and the maintenance of their governments, are as much within the design and care of the Constitution as the preservation of the Union and the maintenance of the National government. The Constitution, in all its provisions, looks to an indestructible Union composed of indestructible states." Id. at 725 ; see H. Hyman, supra note 6, at 517-18; S. KutLer, supra note 67 , at 108-10.

In Day, the Court construed the 1863 national income tax - the first in the nation's history - to exempt the salaries of state judges from its coverage. Speaking for the Court, Justice Nelson relied primarily on the tenth amendment and on the 30-year-old precedent of Dobbins v. Commissioners of Erie County, 4I U.S. (I6 Pet.) 435 ( 1842 ), in which the Supreme Court had granted federal officials immunity from state taxation. The Civil War and the Reconstruction amendments apparently changed little for Justice Nelson and the majority of the Court: "The general government, and the States, although both exist within the same territorial limits, are separate and distinct sovereignties, acting separately and independently of each other, within their respective spheres." 78 U.S. (II Wall.) at I24. Thus, if the instrumentalities of the federal government required tax immunity from the states for their self-preservation, then those of the states deserved similar exemption. The two governments, the Court concluded, "are upon an equality." Id. at I27. See generally H. Hyman, supra note 6, at 534-35. The holding of Day was not reversed until 1939, in Graves v. New York ex rel. O'Keefe, 306 U.S. 466, 486-87 (I939).

${ }^{128} 83$ U.S. (I6 Wall.) 36 (1873).

${ }^{129} \mathrm{Id}$. at $6 \mathrm{I}, 66-82$.

${ }^{130} I d$. at $78-80$. The Court, relying on Crandall v. Nevada, 73 U.S. (6 Wall.) 35 ( 1867$)$, enumerated the following "privileges and immunities" of national 
excluding almost all civil rights from its purview. ${ }^{131}$ Thus, the fourteenth amendment was interpreted to have no impact on the position of the states in safeguarding fundamental rights; ante bellum federalism's allocation of powers remained essentially unchanged. ${ }^{132}$

This narrow reading of the amendment was reaffirmed two years later in United States v. Cruikshank, ${ }^{133}$ where the Court held that the right to assemble to petition for a redress of grievances was not a component of the rights of national citizenship unless the petition was directed to the United States government. ${ }^{134}$ Cruikshank also contributed to the emerging doctrine that the fourteenth amendment could reach the conduct only of state governments or state officials, and not of private persons. Chief Justice Waite found that the amendment "adds nothing to the rights of one citizen against another." ${ }^{135}$ The state action

citizenship: the right to come to the seat of government to participate in or transact business with the government; free access to national seaports, subtreasuries, land offices, and courts; the care and protection of the national government when on the high seas or in a foreign jurisdiction; the right to assemble peaceably and petition the national government for redress of grievances; the writ of habeas corpus; the use of navigable waters; the benefit of any rights derived from a treaty with a foreign government; the right to become a citizen of another state; the right to due process and equal protection; and the rights secured by the thirteenth and fifteenth amendments. See 83 U.S. (I6 Wall.) at $79-80$.

${ }^{131}$ See R. Carr, Federal Protection of Civil Rights: Quest for a Sword 44 (I947).

${ }^{132}$ See generally Graham, supra note 42.

${ }^{133} 92$ U.S. $542(1876)$.

${ }^{134} I d$. at $55^{1-52}$. In Cruikshank, the Court applied the narrow interpretation of the privileges and immunities of citizens of the United States which it had given to the fourteenth amendment in the Slaughterhouse Cases to the civil rights legislation adopted under the amendment. Cruikshank involved the application of one of the key provisions of the post-Civil War civil rights legislation $-\S 6$ of the Act of May 3I, I870, ch. II4, I6 Stat. I40 (current version at I8 U.S.C. § $24 \mathrm{I}$ (I970)), which made it a federal crime for two or more persons to conspire to interfere with a citizen's exercise of any rights granted to him by the laws or Constitution of the United States. Three persons who had forcibly broken up a meeting of blacks in Louisiana, and participated in the lynching of two of the blacks, were indicted and convicted under the criminal conspiracy provision. 92 U.S. at $548,552-53$. In a decision setting aside the convictions, the Supreme Court refrained from voiding the provision but drastically limited its usefulness. The right to assemble peaceably was not seen as an attribute of national citizenship, unless it was directly related to the functioning of the federal government. Id. at 55I-52. In effect, Congress, in the exercise of its power to enforce the fourteenth amendment by appropriate legislation, see U.S. CoNsT. amend. XIV, \&5, was allowed to legislate only on the limited relationship between the citizen and the federal government. See generally $R$. CARR, supra note I3I, at 45 .

${ }^{135} 92$ U.S. at 554 . Unlike the cases which subsequently established the state action requirement, Cruikshank did not regard private misconduct as wholly out- 
prerequisite for invoking federal protection was reiterated in United States v. Harris ${ }^{136}$ and the Civil Rights Cases. ${ }^{137}$ Moreover, although executive and judicial conduct sanctioned by the

side congressional reach. Cruikshank recognized that there might be constitutional rights derived from sources not subject to the state action limitation, and that those might accordingly be protected against private as well as state interferences. Thus, the Court suggested that when the purpose of an assembly or petition had direct bearing upon the national government's powers or duties, the Constitution, by implication, protected these rights from private as well as governmental threats. See id. at 554. See also United States v. Guest, 383 U.S. 745, 762, 77I-72 (I966) (Harlan, J., concurring in part and dissenting in part) (interpreting Cruikshank as "announc[ing] in dicta a federal right to assemble to petition the Congress for a redress of grievances"); G. GuntheR, supra note 37, at 962-63.

${ }^{136} 106$ U.S. 629 (1882). Harris held unconstitutional part of $\S 2$ of the Act of April 20, 1871, ch. 22, I7 Stat. 13, providing criminal penalties for conspiracy to deprive any person of "the equal protection of the laws, or of equal privileges or immunities under the law." Harris, a private person, was charged with participating in a lynching - killing one person as well as beating three others while they were in the custody of a Tennessee sheriff. ro6 U.S. at 629-32. The Supreme Court sustained a demurrer, holding the legislation unconstitutional because in providing sanctions against private conduct, it went beyond Congress' authority to enforce the fourteenth amendment. Id. at 638 . The provision was repealed in 1909. Cf. Griffin v. Breckinridge, 403 U.S. 88 (197I) (upholding the constitutionality of 42 U.S.C. $\$$ I985(3) (I970), the civil counterpart to the civil rights conspiracy provision, which was found applicable to private conspiracies).

${ }^{137}$ 109 U.S. 3 ( 1883 ). These five cases involved proceedings against private persons under $\S \S \mathrm{I}$ and 2 of the Civil Rights Act of March I, I875, ch. II4, I8 Stat. 335, imposing criminal penalties for private discrimination on the basis of race in public accommodations such as hotels, theaters, and railway cars. The legislation was held unconstitutional as beyond the power of Congress to enforce the fourteenth amendment because it was directed against private discrimination. Iog U.S. at II. The Civil Rights Cases became the foundation for the requirement of state action in suits under the fourteenth amendment. See, e.g., G. Gunther, supra note 39, at 906, 9I4-15. See also Virginia v. Rives, 100 U.S. 313, 317-18 (1879) (dicta) (limiting the fourteenth amendment and legislation enacted pursuant to it to "State action exclusively").

The state action requirement became sufficiently entrenched in fourteenth amendment analysis that it was soon extended to the thirteenth and fifteenth amendments. See, e.g., James v. Bowman, I90 U.S. 127 (1903) ( $\$ 5$ of the Act of May 31, 1870, providing criminal penalties for interfering with the right to vote, held unconstitutional under the fifteenth amendment because it was directed against private persons as well as state officers); Hodges v. United States, 203 U.S. I (I906) (reversing convictions obtained under the civil rights criminal conspiracy statute (currently codified at I8 U.S.C. \$ $24 \mathrm{I}$ (1970)) for a conspiracy to prevent a group of blacks from exercising their right established in $\S \mathrm{I} 6$ of the Act of May 3I, 1870, I6 Stat. I40, to make contracts for employment; federal protection against private interferences with the right to make contracts was found to be beyond the scope of congressional power under the thirteenth amendment), overruled in Jones v. Alfred H. Mayer Co., 392 U.S. 409, $44 \mathrm{I}$ n.78 (1968). See also Howe, supra note 45 , at 25 (criticizing the extension of state action analysis to the thirteenth amendment as inconsistent with the purposes of the amendment's framers). 
state was deemed to be "state action," conduct by state officers in violation of their authority was not. ${ }^{138}$ Thus, that very lawless-

${ }^{138}$ See, e.g., Barney v. City of New York, I93 U.S. 430, 438-39 (1904); cf. Virginia v. Rives, I00 U.S. 313, 319-21 (1879) (removal provision of Civil Rights Act of I866 (current version at 28 U.S.C. $\$$ I 443 (I) (I970)) held to permit removal of state criminal proceeding to federal court only where a state statute denies, or interferes with the enforcement of, equal rights; assertion that state judge is likely to deny those rights during the trial through action illegal under state law insufficient to warrant removal). See also The Civil Rights Cases, rog U.S. 3, I7 ( 1883 ) (dictum) (state action defined as conduct pursuant to state authority in "the shape of laws, customs, or judicial or executive proceedings").

The Supreme Court never clearly and unequivocally held that the action of state officers in violation of state law could not constitute the state action requisite under the fourteenth amendment. In Barney, the Court determined that it was without jurisdiction to enjoin the city's construction of a rapid transit tunnel adjacent to plaintiff's premises, where plaintiff had claimed that the construction was in violation of the state statute authorizing the general plan of rapid transit construction. The Court, in finding that there had been no state deprivation of property without due process, used language suggesting that conduct in violation of state law could not be "state action":

[The complaint] proceeded on the theory that the construction ... was not only not authorized, but was forbidden by the legislation, and hence was not action by the State of New York within the intent and meaning of the I4th Amendment. . . . Complainant's grievance was that the law of the State had been broken, and not a grievance inflicted by action of the legislative or executive or judicial department of the State; and the principle is that it is for the state courts to remedy acts of state officers done without the authority of, or contrary to, state law.

I93 U.S. at 483. Barney, however, has been plausibly interpreted as simply the Supreme Court's rejection of a claim that the mere violation of state law by state officials is necessarily a violation of the fourteenth amendment due process clause. See HART \& WeChSLER, supra note 87 , at 942.

Despite the lack of a conclusive decision of the applicability of the fourteenth amendment to state officer action in the nineteenth century, it was widely assumed that action in violation of state law could not be state action, see, e.g., Monroe v. Pape 365 U.S. 167, 202, 212-17 (196I) (Frankfurter, J., dissenting in part) ; Shapo, supra note 104, at 284-85; Isseks, Jurisdiction of the Lower Federal Courts to Enjoin Unauthorized Action of State Officials, 40 Harv. L. REv. 969, 969 (I927), and a number of lower federal courts explicitly took that position, see, e.g., Huntington v. City of New York, I 18 F. 683 (C.C.S.D.N.Y. I902), aff'd, I93 U.S. 44I (1904); Kiernan v. Multnomah County, 95 F. 849 (C.C.D. Or. I899); Manhattan Ry. v. Mayor of City of New York, I8 F. I93 (C.C.S.D.N.Y. I883).

Moreover, the cases brought during the nineteenth century under the civil rights acts charging deprivations "under color" of state law almost uniformly involved action taken either in pursuance of some specific command of state law or within the scope of executive discretion in the administration of state laws. See, e.g., Giles v. Harris, I89 U.S. 475 (1903) ; Bowman v. Chicago \& N.W. Ry., II5 U.S. 6II (I885); Carter v Greenhow, II4 U.S. 317 (1885); Crystal Springs Land \& Water Co. v. City of Los Angeles, 76 F. I48 (C.C.S.D. Cal. I896), aff'd, 177 U.S. I69 (1897); Fraser v. McConway \& Torley Co., 82 F. 257 (C.C.D. Pa. 1897); Davenport v. Cloverport, 72 F. 689 (D. Ky. I896); Helmsley v. Myers, 45 F. 283 (C.C.D. Kan. 1891 ) ; Tuchman v. Welch, 42 F. 548 (C.C.D. Kan. I890). In two actions under the civil rights acts where the question of whether the official conduct involved might have been in violation of state law arose, the courts found 
ness of government agents the prevention of which had been the primary object of the Act of $187 \mathrm{I}$ was immunized from federal sanction.

The effect of such a narrow judicial construction of state action and "privileges and immunities" on section r 983 was devastating. Despite continuing infringement of the civil liberties of the freedmen and their descendants, virtually no actions were brought under the statute. ${ }^{139}$ By the turn of the century, federal protection of these rights had declined to the point that the Southern states were able to introduce Jim Crow laws, resembling the Black Codes, which imposed patently exclusionary "literacy" tests on blacks as a requirement of voting. ${ }^{140}$ The federal courts, notwithstanding the fact that it was a specific purpose of civil rights legislation to secure the vote for freedmen, were reluctant to intervene even in cases where state officials disenfranchised blacks with the obvious approval of the state government, and outrages grimly reminiscent of those perpetrated by the Klan were held to be beyond the scope of section $1983 .{ }^{141}$ Throughout the period between the end of Reconstruction and the Depression, the federal judiciary seemed disposed to allow a relatively wide latitude to state police power, and to place higher priority on the preservation of a tranquil federalism than on the safeguarding of individual civil rights.

2. Views of Federalism. - Even as the Supreme Court was subordinating the national interest in civil rights enforcement to its concern for the maintenance of traditional notions of federalism, the premises upon which those ante bellum views were based were being profoundly altered. The Civil War and the peaceful resolution of the Reconstruction in 1877 ushered in a period of

the civil rights laws inapplicable. See Brawner v. Irvin, I69 F. 964 (C.C.N.D. Ga. I909); United States v. Jackson, 26 F. Cas. 563, 563-64 (C.C.D. Cal. 1874) (No. 15,459$)$.

${ }^{139}$ Between I87I and I920, only 21 cases were brought under $\S$ I983. See Comment, The Civil Rights Act: Emergence of an Adequate Federal Civil Remedy?, 26 Ind. L.J. 36I, 363 (I95I). As late as I953, the statute was still relatively ineffective. See generally Note, The Proper Scope of the Civil Rights Acts, 66 HaRv. L. Rev. I 286 (1953).

${ }^{140}$ See, e.g., Ala. Const. of I90I, art. VIII, $\$ \S$ I80-I87 (I902); Ga. Const. of I877, art. 2 , § I ( I 908$)$; LA. Const. of 1898 , art. I97, $\$ \S 2-5$; Miss. Const. of 1890 , art. I2, §§ $24 \mathrm{I}-245$; N.C. Const. of 1876, art. 6, $\$$ I-4 (I900); S.C. Const. of 1895, art. 2, § 4. See generally Monnet, The Latest Phase of Negro Disenfranchisement, 26 Harv. L. Rev. 42 (I912); see also James v. Bowman, I90 U.S. 127 (1903); Giles v. Harris, I89 U.S. 475 (1903).

${ }^{141}$ See, e.g., Brawner v. Irvin, I69 F. 964 (C.C.N.D. Ga. 1909) (dismissing a \& I 983 action against a southern police officer who whipped and assaulted the female plaintiff in public, detained her, and eventually released her without charge; the court saw no deprivation of any constitutionally or federally secured privilege or immunity). 
intense nationalism. Gone, seemingly forever, was the ante bellum attitude that the states were the primary centers of political life. The doctrines of secession and nullification and the view of the nation as no more than a compact of states, which had characterized the early debates over the nature of the federal system, had been rendered untenable by the outcome of the war. The nation became the focus of popular loyalties, the supremacy of the national government over the states was everywhere acknowledged, at least in theory, and the United States was increasingly regarded as one organic entity rather than a collection of states. ${ }^{142}$

Equally significant for the development of a new view of federalism was the steady erosion of the prewar economic order. In the decades between the Civil War and the Depression the nation of small farms and industries serving and being served by primarily local areas steadily vanished; technological innovation and the emergence of new forms of industrial organization led to the development of a rapidly growing economy of national scope. $^{143}$ The disappearance of a small-scale economy meant the effective termination of the era in which states and communities could easily regulate business enterprises. ${ }^{144}$ Even in agriculture, where much production remained in the hands of small operators, expanded markets made these operators dependent upon conditions which they and the state governments were unable to control. ${ }^{145}$ As a result, as Professor Schlesinger has written, the people who sought to "curb the mighty forces remaking the economic order ... turned to Washington, not to their legislatures, for decisive action." 146

This combination of a psychology of nationalism and the emerging need for national governmental action to deal with the economy led to an unprecedented period of national peacetime regulation. The first administrative agencies were established to supervise the conduct of interstate carriers, businesses engaged in interstate commerce, and banks and financial institutions. The federal government became involved in the regulation of railroad rates, the dissolution of monopolies, and the establishment of health and safety regulations governing both the conditions of

${ }^{142}$ See generally W. Bennett, supra note 6, at I79-95; I J. BRyce, The American Commonwealth 533-34 (I888); 2 S. Morison \& H. Commager, supra note 6, at I03-06; A. Schlesinger, The Rise of Modern AMerica, I865I95I, at I62-66 ( I95I).

${ }^{143}$ See generally W. Bennetr, supra note 6 , at $198 ; 2$ S. MORIson \& H. CoMMAGer, supra note 6, at 165-223; A. SChlesINGer, supra note 142, at 27-50, 82-106.

${ }^{144}$ See, e.g., H. Hyman, supra note 6 , at 8.

${ }^{145}$ See W. BenNetT, supra note 6, at 198.

${ }^{146}$ A. SCHLESINGER, supra note $\mathrm{I}_{42}$, at $\mathrm{I} 64$. 
labor and the quality of consumer goods sold in interstate commerce. ${ }^{147}$

While the President and Congress in this era may be seen as moving steadily toward the creation of an affirmative federal role in the regulation of the national economy, the Supreme Court took a more ambiguous stance. A concern for the maintenance of a free flow of commerce throughout the nation and the need for uniformity in commercial matters implicating national concerns often led the Court to give an expansive reading to the negative implications of the commerce clause. ${ }^{148}$ State enactments purporting to exclude certain goods ${ }^{149}$ or keep the products of a state within that state ${ }^{150}$ were regularly struck down, as were state taxes which discriminated against goods which originated outside the state. ${ }^{151}$ Moreover, the metaphor of a "flow" of commerce enabled the Court to uphold federal regulation of the intrastate portions of certain types of interstate business activities. ${ }^{152}$ Yet for the most part, the Court in this era resisted the notion that in an economy of national scope all stages in the process of production, transportation, and distribution for a national market are part of a continuous flow in which local phases are submerged. For example, in United States v. E.C. Knight Co. ${ }^{153}$ the Court concluded that the Sherman Antitrust Act could not be applied to reach the activities of the sugar trust, which

${ }^{147}$ See generally 2 S. MORISON \& H. CoMmager, supra note 6, at 165-224, 476-503. Although the regulation of labor relations remained largely a matter of state concern, see W. BENNETT, supra note 6 , at 198 , when the harsh conditions of industrial life provoked labor unrest on a national scale the national government was not slow to act; thus President Cleveland defied Governor Altgeld of Illinois and the states' rights interpretation of the Constitution in 1894 and ordered federal troops into Illinois over the Governor's objection to quell the Pullman strike. See A. Schlesinger, supra note 142 , at I64. Cleveland's action was vindicated by the Supreme Court in In re Debs, I58 U.S. 564 (1895). See also J. SCHMIDHAUSER, supra note $\mathrm{r} 9$, at $13 \mathrm{I}-32$.

${ }^{148}$ See, e.g., Leisy v. Hardin, I35 U.S. I00 (I890); Bowman v. Chicago \& N.W. Ry., I25 U.S. 465 (I887) ; Wabash, St. L., \& P. Ry. v. Illinois, Ir 8 U.S. 557 (1886); Welton v. Missouri, I9 U.S. 275 ( 1875 ).

${ }^{149} \mathrm{See}$, e.g., Austin v. Tennessee, I79 U.S. 343 (I900); Schollenberger v. Pennsylvania, I7I U.S. I (I898); Minnesota v. Barber, I36 U.S. 3 I3 (1890); Leisy v. Hardin, I35 U.S. Ioo (1890). See generally E. ConwIN, supra note 6, at r8-r9.

${ }^{150}$ See, e.g., Foster-Fountain Packing Co. v. Haydel, 278 U.S. I (1928); Pennsylvania v. West Virginia, 262 U.S. 553 (I923) ; West v. Kansas Natural Gas Co., 22 I U.S. 229 (I9II).

${ }^{151}$ See, e.g., Baldwin v. G.A.F. Seelig, Inc., 294 U.S. 5 I I (1935); Welton v. Missouri, 9r U.S. 275 ( 1875 ).

${ }^{152}$ See, e.g., Stafford v. Wallace, 258 U.S. 495, 515-16 (1922); Swift \& Co. v. United States, r96 U.S. 375 (1905). See generally E. CoRwIN, supra note 6, at 40-43.

${ }^{153}$ I 56 U.S. I (I 895$)$. 
had acquired nearly complete control over the domestic manufacture of refined sugar, because manufacturing was a purely local concern. ${ }^{154}$ And in Hammer v. Dagenhart, ${ }^{155}$ the Court invalidated a congressional statute forbidding the shipment in interstate commerce of the products of child labor. ${ }^{156}$ In doing so, the Court emphasized the importance of the interest in state autonomy which the statute would infringe. "The Nation is made up of States to which are entrusted the powers of local government"; ${ }^{157}$ to uphold the child labor act and thereby allow Congress to regulate matters traditionally entrusted to local authority through the device of prohibiting transport in interstate commerce would mean that "the power of the States over local matters may be eliminated, and thus our system of government be practically destroyed." 158

${ }^{154}$ See id. at 17 .

155247 U.S. 25 I (1918).

${ }^{156} I d$. at $276-77$. Writing for the Court, Justice Day appeared to rest his decision on two grounds: that the Act was not a regulation of commerce among the states, see id. at $270-75$, and that, further, it was an invasion of the powers which the Constitution reserved to the states, see id. at 275-77. Much of the notoriety of Justice Day's opinion appears to derive from the second prong of his analysis. See, e.g., E. Corwin, supra note 6, at $26-37$; J. Schmidhauser, supra note 19 , at $150-15 \mathrm{r}$.

In demonstrating that the statute was in excess of the commerce power, Justice Day sought to distinguish it from other decisions upholding congressional legislation prohibiting the transportation through interstate commerce of lottery tickets, see Champion v. Ames, I88 U.S. 32 I (1903), adulterated products, see Hipolite Egg Co. v. United States, 220 U.S. 45 (I9II), or women for the purposes of prostitution, see Hoke v. United States, 227 U.S. 308 (I913). In the previous cases the goods regulated were harmful in themselves or "the use of interstate transportation was necessary to the accomplishment of harmful results," 247 U.S. at 27 I. However, in the case of child labor, said Justice Day, the act aimed "to standardize the ages at which children may be employed in mining and manufacturing within the states," an objective outside the scope of the federal commerce power. Id. at 274 .

${ }^{157}$ Id. at 275 .

${ }^{158} I d$. at 276 . Although the emphasis on the interest in state autonomy and the protection afforded the reserve powers of the states by the tenth amendment appear to suggest the existence of an independent constitutional barrier to the exercise of federal authority, Justice Day was careful to demonstrate the lack of federal authority as well. See note 156 supra.

The Dagenhart case underscored the basic paradox inherent in the use of dual federalism to preserve state autonomy. In the previous decades the Court had done much in protecting the development of a national economy which effectively weakened the state regulatory power championed in Dagenhart. Thus, an individual state seeking to take action against the abuses of child labor could not by itself proscribe the importation of goods made in other states which were the product of child labor. Moreover, the judicially enforced free competition among the states on a national scale tended to discourage social experimentation in this area because legislators feared that if they curtailed the use of child labor in their own states, competing states which had not adopted similar progressive legislation 
The Court's willingness to impose restrictions on federal legislative power in order to preserve areas of state autonomy was unmatched by any similar willingness to allow concern for state interests to limit judicial authority to restrain state regulatory activity. Finding corporations to be persons within the meaning of the fourteenth amendment, ${ }^{159}$ the Court infused the amendment's due process clause with substantive content reflecting laissez faire notions and designed to protect corporate interests from state economic legislation. Through the incorporation into the due process clause of the doctrine of liberty of contract ${ }^{160}$ and the requirement that administratively determined railroad and utility rates meet an ill-defined standard of reasonableness ${ }^{161}$ the Court effectively arrogated to itself the power to define the limits of state regulatory, and especially rate-fixing, competence. At the same time, the Court moved to guarantee broad access to the lower federal courts to corporate plaintiffs, ${ }^{162}$ thereby contributing to the further erosion of state autonomy and integrity.

The immunity of the states to suit in federal court, which had been first pierced in Chisholm v. Georgia ${ }^{163}$ and then restored by the eleventh amendment, ${ }^{164}$ was again set aside to assure federal judicial protection of economic rights threatened with unsympa-

could reap an economic advantage from their ability to sell their products at lower prices - given the relative cheapness of child labor - as well as through the migration of industries using child labor.

With both the states and the federal government after Dagenhart thus effectively precluded from regulating certain phases of economic activity, dual federalism, as Professor Corwin wrote, had created a "triple federalism" with a "political 'no-man's land'" between the states and the national government where no regulation was constitutionally permissible. See E. Corwin, supra note 6, at 34-35.

${ }^{159}$ See Santa Clara County v. Southern Pac. R.R., I18 U.S. 394 (1886). See also Richmond, F. \& P.R.R. v. Richmond, 96 U.S. 52I (1878); Chicago, B. \& Q.R.R. v. Iowa, 94 U.S. 155 (1877).

${ }^{160}$ See, e.g., Allgeyer v. Louisiana, I65 U.S. 578 (1897). See also Lochner v. New York, 198 U.S. 45, 74-76 (1905) (Holmes, J., dissenting).

${ }^{161}$ See, e.g., Smyth v. Ames, 169 U.S. 466 (1898); Reagan v. Farmers Loan \&

Trust Co., 154 U.S. 362 (1893).

${ }^{162}$ See Neuborne, supra note 88, at I107-08.

${ }^{163} 2$ U.S. (2 Dall.) 4 19 (1793).

${ }^{164}$ The eleventh amendment provides:

The Judicial power of the United States shall not be construed to extend to any suit in law or equity, commenced or prosecuted against any one of the United States by Citizens of another State, or by Citizens or Subjects of any Foreign State.

U.S. Const. amend. XI.

In deciding eleventh amendment cases, the Supreme Court has generally looked beyond the language of the amendment and focused on the principle of sovereign immunity. See, e.g., Hans v. Louisiana, I34 U.S. I (1890); Tribe, Intergovernmental Immunities in Litigation, Taxation, and Regulation: Separation of Powers Issues in Controversies About Federalism, 89 HARv. L. REv. 682, 683-86 (I976). 
thetic treatment by the states. In Ex parte Young, ${ }^{165}$ the Court sustained a federal circuit court contempt citation against the Attorney General of Minnesota for violating a federal court injunction prohibiting him from enforcing a railroad ratemaking statute alleged to violate the due process clause. Speaking for the Court, Justice Peckham found that where the action of the state officer against whom injunctive relief is sought is alleged to be unconstitutional, the suit "does not affect the State in its sovereign or governmental capacity," and, thus, the federal court could enjoin the state official from implementing the state law. ${ }^{166}$ Through a somewhat artificial if not illogical distinction between the state officer formally standing suit and the state policy actually at issue, $E x$ parte Young reaffirmed the significance of the fourteenth amendment as a subjection of state sovereignty and substantive lawmaking power to federal standards, while guaranteeing that federal courts would continue to be available as primary agencies for the enforcement of those federal requirements.

The decision in Home Telephone \& Telegraph Co. v. City of Los Angeles ${ }^{167}$ also sought to assure the practical availablity of federal judicial enforcement of the fourteenth amendment against the states. In so doing, the Court implicitly rejected a notion of a state as an integral unit, with any substantial interest attaching to correction and control by state - as opposed to federal courts. ${ }^{168}$ In Home Telephone, the city of Los Angeles argued that because the telephone rates it had fixed which were alleged to violate the due process clause also assertedly violated a similar provision of the state constitution, its acts could not be treated as state action under the fourteenth amendment nor reviewed by the lower federal courts until the state courts had passed on the case and determined the acts to be authorized under state law. ${ }^{169}$ The Court rejected that contention, finding that if it were accepted, then "at least in every case where there was a coincidence between a national safeguard or prohibition and a state one," the power of the federal court to vindicate constitutional rights against the states "would depend on the ultimate determination of the state courts." ${ }^{170}$ Such a result would be unacceptable since it would "cause the state courts to become the primary source" for defining and enforcing constitutional rights. ${ }^{171}$

Thus, the concerns for federalism and state autonomy which

\footnotetext{
165209 U.S. I23 (I908).

${ }^{166} I d$. at $159-60,163,166-68$.

167227 U.S. 278 (I9I3).

168 See pp. I270-7 I infra.

169227 U.S. at $282-83$.

${ }^{170} \mathrm{Id}$. at $284-85$.

${ }^{171}$ Id. at 285 .
} 
led the Court to restrict the scope of federal economic regulation did not preclude a vigorous role for the federal judiciary in enforcing constitutional rights. And in vindicating the corporate interests implicated in the constitutional litigation of this era, the Court developed some of the doctrinal tools which, when its attention turned to civil rights enforcement, would make section I 983 such a potent and controversial cause of action.

\section{The Emergence of Section 1983}

During the I920's, the use of section 1983 was for the most part confined to deprivations of voting rights. ${ }^{172}$ Unlike the situation around the turn of the century, ${ }^{173}$ however, section 1983 plaintiffs began to achieve a measure of success. In 1927 , the Supreme Court allowed an action for damages against election judges who in compliance with a Texas statute had prohibited blacks from voting in a Democratic primary. ${ }^{174}$ Writing for a unanimous Court in Nixon v. Herndon, ${ }^{175}$ Justice Holmes stated that "it seems to us hard to imagine a more direct and obvious infringement of the Fourteenth Amendment." ${ }^{176}$ And a dozen years later, the Court in Lane v. Wilson ${ }^{177}$ upheld the right of blacks to sue for damages sustained because they were effectively denied the franchise by a discriminatory state statute. ${ }^{178}$

In the same year, the statute received its first significant application in a case not involving race discrimination or the franchise. ${ }^{179}$ In Hague v. CIO, ${ }^{180}$ the Court affirmed a decision restraining various Jersey City officials, acting pursuant to a local ordinance, from harrassing the plaintiff labor organizers. ${ }^{181}$ Although the Justices divided ${ }^{182}$ over whether the right to as-

${ }^{172}$ See Shapo, supra note 104, at 282-84; Comment, supra note 139 , at 370.

${ }^{173}$ See pp. II 57-6I supra.

${ }^{174}$ Nixon v. Herndon, 273 U.S. 536, 540-4I (1927).

175273 U.S. 536 (1927).

${ }^{176}$ Id. at $54 \mathrm{I}$.

177307 U.S. 268 (1939).

${ }^{178}$ Id. at 274. See also Smith v. Allwright, 32 I U.S. 649 (I944); Nixon v. Condon, 286 U.S. 73 (1932).

${ }^{179}$ See Hague v. CIO, 307 U.S. 496 (1939); Note, supra note 139, at 1287.

${ }^{180} 307$ U.S. 496 (1939).

${ }^{181}$ Id. at 500 .

182 Justice Roberts, joined by Justice Black, wrote the principal opinion, declaring the ordinance void and enjoining its enforcement. This opinion saw the right to discuss federal legislation as a privilege of national citizenship, secured by the fourteenth amendment. Id. at 5I2-I4. Justices Stone and Reed concurred on the grounds that freedom of speech and assembly are secured by the due process clause; they refused to accept the privileges and immunities argument. Id. at $5 \mathrm{I} 8$, 519. Chief Justice Hughes concurred separately, agreeing with Justice Roberts that the right to discuss federal legislation was a national "privilege," but agreeing with Justice Stone in his view that the record did not adequately support jurisdic- 
semble and organize under the National Labor Relations Act was a privilege or immunity of national citizenship ${ }^{183}$ or was a component of first amendment protections incorporated into the fourteenth amendment due process clause, ${ }^{184}$ a majority of the Court agreed that the ordinance was unconstitutional and enjoined its enforcement. ${ }^{185}$

Nixon v. Herndon, Lane v. Wilson, and Hague v. CIO each involved official action taken pursuant to an unconstitutional state statute or local ordinance, and thus fit squarely within the traditional narrow definition of "under color" of law. In I94I, however, that requirement of suits under the civil rights acts received a major reinterpretation. In United States v. Classic, ${ }^{186}$ the Supreme Court reversed the dismissal of charges brought under the criminal provisions of these acts ${ }^{187}$ against election officials who had fraudulently counted ballots in a primary - a clear violation of state law. ${ }^{188}$ Commenting on the "under color" phrase, the Court implicitly rejected the premise that the term required that conduct be authorized by a state statute: "Misuse of power, possessed by virtue of state law and made possible only because the wrongdoer is clothed with the authority of state action is action taken 'under color of' state law." 189

Four years later this redefinition of the "under color" requirement was reaffirmed by a closely divided Court. In Screws v. United States, ${ }^{190}$ the Court held that a sheriff's fatal beating of a black prisoner constituted conduct "under color" of the law. ${ }^{191}$ Speaking for the four-member plurality, ${ }^{192}$ Justice Douglas adopted the construction of "under color" announced in Classic, defining the term as "under 'pretense' of law." 193

Classic and Screws thus established that at least in criminal

tion on that ground. Id. at 532. Justices McReynolds and Butler dissented; Justices Frankfurter and Douglas did not participate.

${ }^{183}$ Id. at 5 I 2 (Robert \& Black, JJ.); id. at 532 (Hughes, C.J., concurring).

${ }^{184}$ Id. at 5 I9 (Stone \& Reed, JJ.).

${ }^{185} \mathrm{Id}$. at 500 .

${ }^{186} 3$ I3 U.S. 299 (I94I).

${ }^{187}$ Sections 6 and 17 of the Act of May 3I, 1870, ch. II4, I6 Stat. I4I (current version at 18 U.S.C. $\$ \$ 24 \mathrm{I}, 242$ (I970)).

${ }^{188} 313$ U.S. at 328.

189 Id. at 326 .

${ }^{190} 325$ U.S. 91 (1945).

${ }^{191}$ Id. at 107. Although defendant's action was held to be "under color of" state law, the Court reversed the sheriff's conviction because the trial judge had not properly instructed the jury on the nature of the specific intent necessary to support a conviction. See id. at 106.

${ }^{192}$ Joining Justice Douglas' plurality opinion were Chief Justice Stone and Justices Black and Reed. Justice Rutledge concurred in the result in a separate opinion. Justices Roberts, Frankfurter, Jackson, and Murphy dissented.

${ }^{193}$ Id. at III. 
actions, conduct "under color" of law encompasses unauthorized and indeed unlawful conduct of a state officer, so long as the "pretense" of authority with which he acted furthered in any way the constitutional violation. ${ }^{194}$ These decisions made section I983 increasingly available for suits alleging police misconduct ${ }^{195}$ and deprivations of first amendment rights, ${ }^{196}$ which by their number and the nature of the issues framed provided significant impetus to the modern expansion of the scope and impact of the statute.

In the decade following Screws, the potential reach of section I 983 was considerably enlarged by the gradual incorporation of the guarantees of the Bill of Rights into the due process clause and the emergence of the modern equal protection and due process doctrines. Although section I $_{9} 83$ does not specifically encompass these provisions, the ambit of the statute is determined by that of the fourteenth amendment which it was enacted to enforce, and as the latter came to comprehend a wider variety of interests, the foundation for a broad interpretation of the civil rights acts was laid.

Monroe v. Pape ${ }^{197}$ resurrected section 1983 from ninety years of obscurity. The facts in Monroe were reminiscent of the "outrages" which had prompted the passage of the Act of $187 \mathrm{I} .{ }^{198}$ Plaintiff and his family sued thirteen Chicago policemen and the city of Chicago, alleging that the police had broken into their home without a warrant, forced them out of bed at gunpoint, made them stand naked while the officers ransacked the house, and subjected the family to verbal and physical abuse. ${ }^{199}$ The defendants then allegedly took Monroe to the police station where he was held incommunicado and interrogated for ten hours before he was released without being charged. ${ }^{200}$ Plaintiffs claimed that the defendants' action constituted a deprivation "under color" of law of their constitutional guarantee against unreasonable searches. The district court dismissed the complaint ${ }^{201}$ and the

${ }^{194}$ See United States v. Classic, 313 U.S. 299, 326 (194I). See also Hague

v. CIO, 307 U.S. 496, 507 (1939).

${ }^{195} \mathrm{See}$, e.g., Jackson v. Duke, 259 F.2d 3 (5th Cir. 1958); Coleman v. Johnston, 247 F.2d 273 (7th Cir. 1957); Geach v. Moynahan, 207 F.2d 714 (7th Cir. I953); Valle v. Stengel, I76 F.2d 697 (3d Cir. 1949); Picking v. Pennsylvania R.R., I5 I F.2d 240 (3d Cir. 1945), cert. denied, 332 U.S. 776 (1947).

${ }^{196}$ See, e.g., Sellers v. Johnson, I63 F.2d 877 (8th Cir. 1947); Hannan v. City of Havershill, I20 F.2d 87 (Ist Cir. I94I); Stapleton v. Mitchell, 60 F. Supp. 5 I

(D. Kan. 1945). See also Comment, supra note 139, at 374-76.

${ }^{197} 365$ U.S. 167 (i 1961 ).

${ }^{198}$ See pp. II53-54 supra.

${ }^{199} 365$ U.S. at 169.

${ }^{200} I d$.

${ }^{201}$ Record at 20 (unreported opinion of the United States District Court for the Northern District of Illinois, June 5, 1959). 
Seventh Circuit affirmed. ${ }^{202}$ The Supreme Court granted certiorari and reversed in part. ${ }^{203}$

Justice Douglas, writing for the Court, readily found that the defendants' conduct violated the plaintiffs' constitutional rights ${ }^{204}$ and held that the definition of "under color of" law for section I 983 purposes was the same as that established in the criminal context. As a result, the ultra vires nature of the officers' activity did not preclude relief. ${ }^{205}$ The Court also concluded that since section I 983 provides for a civil action and - unlike the criminal civil rights conspiracy statute - does not contain an explicit requirement that the defendants' conduct be willful, plaintiffs need not prove that the defendant acted with "a specific intent to deprive a person of a federal right." ${ }^{206}$ But despite the broad reach given section 1983 , Justice Douglas held that municipalities here the city of Chicago - were immune from liability under the statute. ${ }^{207}$

In reaching these conclusions, Justice Douglas relied heavily upon the legislative history of the statute. ${ }^{208} \mathrm{He}$ discerned three purposes underlying the original enactment of the measure in I $87 \mathrm{I}$ : to override discriminatory state laws; ${ }^{209}$ to provide a remedy where state law was inadequate; ${ }^{210}$ and to provide a federal remedy where the state remedy, although adequate in theory, was not available in practice. ${ }^{211}$ From these purposes Justice Douglas derived the expansive interpretation of "under color" and from this interpretation, a fourth, and the most significant modern, purpose: to provide a supplementary federal remedy.

\footnotetext{
202272 F.2d 365 (7th Cir. 1959).

${ }^{203} 365$ U.S. at 187 (complaint states cause of action against individuals); id. at 192 (municipality immune from suit).

${ }^{204}$ Id. at I7I (citing Elkins v. United States, 364 U.S. 206 (I960); Wolf v. Colorado 338 U.S. 25 (I949)).

${ }^{205} 365$ U.S. at 172 .

${ }^{206}$ Id. at 187 (quoting Screws v. United States, 325 U.S. 9I, I03 (I945)). The holding in Screws, see pp. I168-69 supra, that the criminal liability provisions of the Civil Rights Act, I8 U.S.C. $\$ 242$ (1970), required a showing that the defendant had acted with the specific intent of depriving another of his constitutional rights was necessary to save the statute from the argument that it is unconstitutionally vague. See 325 U.S. at I03. In Monroe, both the majority and Justice Frankfurter, in his dissent, concluded that in the context of a civil action, due process did not require such a rigorous showing and that the standards of tort liability would suffice. See 365 U.S. at 187, 207 n.6. For a further discussion of the difficulties posed by the tort liability standard for $\S 1983$ established in Monroe, see pp. 1204-17 infra.

${ }^{207}{ }_{3} 65$ U.S. at $187-92$.

${ }^{208} \mathrm{See}$ id. at $\mathrm{17} 1 \mathrm{1}, \mathrm{1} 73-83, \mathrm{185}, \mathrm{188-91.}$

${ }^{209} \mathrm{Id}$. at $\mathrm{I} 73$.

${ }^{210}$ Id. at $173-74$.

${ }^{211} \mathrm{Id}$. at 174 .
} 
"The federal remedy is supplementary to the state remedy, and the latter need not be first sought and refused before the federal one is invoked." 212

Justice Harlan concurred in a separate opinion discussing only the issue of the proper scope of the "under color of" requirement. ${ }^{213}$ Although he felt that the legislative history was unclear with regard to the meaning of this term, he saw no substantial evidence in the congressional debates that the Forty-Second Congress intended to distinguish between authorized and unauthorized conduct by state officials for the purposes of section $1983 .{ }^{214}$ Accordingly he felt that on such a legislative record the Court would not be justified in violating the principle of stare decisis by overruling the "under color" definition of Classic and Screws. ${ }^{215}$

Justice Frankfurter dissented, except as to the dismissal of the suit against the city of Chicago. ${ }^{216}$ In an exhaustive analysis of the congressional debates, he argued that while "under color" of state law should have the same meaning in both section I 983 and the criminal conspiracy provision, neither statute should encompass the broad interpretation of Classic and Screws. ${ }^{217} \mathrm{He}$ emphasized the contemporary need to preserve a proper balance in federal-state relations, and argued that Congress had not intended the civil rights acts to absorb ordinary state torts and crimes; accordingly, he contended that Classic and Screws should be overruled. ${ }^{218}$

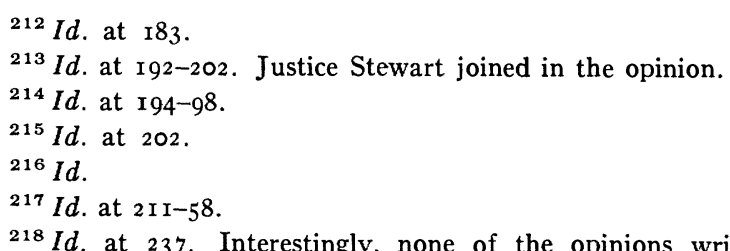

${ }^{218} \mathrm{Id}$. at 237 . Interestingly, none of the opinions written in Monroe dealt directly with the question of the significance of the existence of adequate state remedies for the availability of a $\S 1983$ action in federal court. In adopting the Classic-Screws interpretation of "under color of," with its necessary implication that the requirements for a $\$ 1983$ claim will often be met where the defendants' conduct is in clear violation of state as well as federal law, the question of whether a federal court ought to abstain, or require a $\S \mathrm{I} 983$ plaintiff to exhaust his state remedies before having recourse to a federal forum, assumed a new and critical significance. Justice Douglas, relying on the purposes of the Reconstruction Congress in adopting $\$ 1983$ which he had used to support his expansive reading of the "under color" requirement, found that the availability of adequate state remedies would not preclude a $\S \mathrm{I} 983$ suit from being brought in federal court, nor would it require the exhaustion of state remedies. Id. at 183. However, his conclusion does not necessarily follow from the purposes given, and no other reasons for adopting a "no-exhaustion" requirement were given. Although Justice Frankfurter was more attentive to the federalism implications of an expanded $\S$ I 983 , he too focused almost exclusively on the "under color" issue and failed to treat separately with the question of the sufficiency of available state remedies. 
Since the decision in Monroe v. Pape there has been an extraordinary increase in the volume of civil rights litigation brought in the lower federal courts under section I983. In 1960 only two hundred and eighty suits were filed in federal court under all the civil rights acts; ${ }^{219}$ in 1972 approximately eight thousand claims were filed under section 1983 alone. ${ }^{220}$ Although the Supreme Court has begun to contract the scope of section $1983,{ }^{221}$ the increase in litigation has continued unabated: by 1976 the civil rights case load of the federal courts had increased by more than one hundred percent from the 1972 figures. ${ }^{222}$

This striking increase in section 1983 litigation has prompted several assertions that the availability of the federal civil rights action should be limited. ${ }^{223}$ The need to reduce the pressures on the already crowded dockets of the federal courts has undoubtedly been an important factor in the calls to restrict the ambit of section $1983 .{ }^{224}$ However, as Judge Friendly has noted, "[i]t is hard to conceive a task more appropriate for federal courts than to protect civil rights guaranteed by the Constitution against invasion by the states." 225

More significantly, section 1983 has profoundly disturbed those analysts concerned about maintaining a "proper balance" between the national and state governments. ${ }^{226}$ The statute has increasingly been used as a device for bringing federal court suits which resemble state tort actions against state and local officials. ${ }^{27}$

The issues of abstention and exhaustion in the context of $\S$ r 983 actions will be examined in Parts IV \& V infra.

219 See Administrative Office of the United States Courts, ig6o Annual Report OF THE Director 232, table $\mathrm{C}_{2}$.

${ }^{220}$ See McCormack, Federalism and Section 1983, 60 VA. L. Rev. I, I n.2 ( 1974 )

221 See, e.g., Paul v. Davis, 424 U.S. 693 (1976) ; Rizzo v. Goode, 423 U.S. 362 (I976) ; City of Kenosha v. Bruno, 4I2 U.S. 507 (I973); Moor v. County of Alameda, 4II U.S. 693 (I973) ; Preiser v. Rodriguez, 4II U.S. 475 (I973); Younger v. Harris, 4 or U.S. 37 (I97 I).

${ }^{222}$ See p. II36, note 7 supra.

${ }^{223}$ See, e.g., H. Friendiy, Federal Jurisdiction: A General View 87-107 (1973); Aldisert, Judicial Expansion of Federal Jurisdiction: A Federal Judge's Thoughts on Section 1983, Comity, and the Federal Caseload, I973 LAw \& Soc. ORD. 557 ; Shapo, supra note ro4; Note, supra note Ir 5.

${ }^{224}$ See, e.g., Aldisert, supra note 223, at 558-59. See also H. FRIENdLy, supra note 223, at 87-88; Coffin, Justice and Workability: Un Essai, 5 Suffolk L. Rev. 567, 570 (I97I); Note, Section 1983 and Federalism: The Burger Court's New Direction, 28 U. FLA. L. REv. 904, 915 (1976).

${ }^{225} \mathrm{H}$. FriendLy, supra note 223 , at 90.

${ }^{226}$ See, e.g., Paul v. Davis, 424 U.S. 693, 697-70I (1976) (Rehnquist, J.); Rizzo v. Goode, 423 U.S. 362, 377-80 (1976) (Rehnquist, J.) ; Younger v. Harris, 401 U.S. 37, 44 (I97I) (Black, J.) ; H. FRIENDLY, supra note 223, at 90-92; Aldisert, supra note 223 , at $560-63$.

${ }^{227}$ See generally Aldisert, supra note 223, at 573-74; Note, supra note 224 , at 9 I 7-I8, 924-26. 
Under the rubric of the due process or cruel and unusual punishment clauses, almost any common law tort committed by a state officer can be converted into a constitutional violation and thereby made the basis of a section 1983 action. ${ }^{228}$ Although the use of state officer misconduct which resembles tortious behavior as a "shield" by state criminal defendants is relatively unexceptional today, the use of such behavior as a "sword" to obtain federal jurisdiction and money damages or equitable relief has led to charges that section 1983 is supplanting state tort law and that the federal courts are displacing the state courts from their rightful positions as the primary arbiters of basic standards of duty and conduct. ${ }^{29}$

Section 1983 actions dealing with systemic problems rather than individual conduct have also been subject to attack on federalism grounds. ${ }^{230}$ Here, it is argued that the relief sought is often too sweeping and, if granted, constitutes a substantial federal court derogation of the respect due state and local governments. Suits have been brought against state and local educational, law enforcement, and penal systems, seeking declaratory and injunctive relief which would give the federal courts power to decide major social policy questions and to effect the basic budgetary decisions of state and local governments in ways not necessarily responsive to local needs or popular with local majorities. ${ }^{231}$ This has led to outcries that section 1983 is being

${ }^{228}$ See, e.g., Russ v. Ratliff, 538 F.2d 799 (8th Cir. 1976), cert. denied, 97 S. Ct. 740 (1977); Curtis v. Everette, 489 F.2d $5 \mathrm{I} 6$ (3d Cir. 1973), cert. denied, $4 \mathrm{I} 6$ U.S. 995 (1974); Scott v. Vandiver, 476 F.2d 238 (4th Cir. 1973); Howell v. Cataldi, 464 F.2d 272 (3d Cir. I972); Jenkins v. Averett, 424 F.2d I228 (4th Cir. 1970). But cf. Ingraham v. Wright, 45 U.S.L.W. 4364 (U.S. April 19, 1977) (challenge to corporal punishment practiced by public schools not cognizable under due process and cruel and unusual punishment clauses); Paul v. Dav.s, 424 U.S. 693 (1976) (defamation by police officer not cognizable under due process clause).

${ }^{229}$ See, e.g., Greene v. New York, 38 I F. Supp. 579, 58I (S.D.N.Y. I 967); Aldisert, supra note 223, at 573-74.

${ }^{230}$ See, e.g., Rizzo v. Goode, 423 U.S. 362, 379-80 (1976) (Rehnquist, J.) ; O'Shea v. Littleton, 4I4 U.S. 488, 499-504 (I974) (White, J.). See also Note, Rethinking Federal Injunctive Relief Against Police Abuse: Picking Up the Pieces After Rizzo v. Goode, 7 Rut.-Cam. L.J. 530, 560-62 (1976); Case Comment, Wyatt v. Stickney and the Right of Civilly Committed Medical Patients to Adequate Treatment, 86 HARv. L. REv. I282, I299-1306 (I973); Note, The Federal Injunction as a Remedy for Unconstitutional Police Conduct, 78 YALE L.J. I43, I5I-55 (I 968 ).

${ }^{231}$ See, e.g., Rizzo v. Goode, 423 U.S. 362 (1976) ; O'Shea v. Littleton, $4 \mathrm{I} 4$ U.S. 488 (I974); San Antonio Indep. School Dist. v. Rodriguez, 4 II U.S. I (I973); Morgan v. Kerrigan, 509 F.2d 580 (Ist Cir. I974), aff'g 379 F. Supp. 410 (D. Mass.), enforced by $40 \mathrm{I}$ F. Supp. 216 (D. Mass.), af'd, 523 F.2d 9I7 (Ist Cir. I973); Inmates of Suffolk County Jail v. Eisenstadt, 494 F.2d II96 (Ist Cir. 1974); Rhem v. Malcolm, 37 I F. Supp. 594 (S.D.N.Y. I974), aff'd and remanded, 507 F.2d 333 (2d Cir. I974); Wyatt v. Stickney, 344 F. Supp. 373 (M.D. Ala. 1972), aff'd in part and remanded in part sub nom. Wyatt v. Alderholt, 503 F.2d I305 (5th Cir. 1974). 
used to undermine the proper, constitutionally mandated balance between the federal and state governments by giving federal courts affirmative authority over areas more properly the province of state and local governments. ${ }^{232}$

In recent years, the Supreme Court has begun to give voice to these federalism-based concerns. States and localities have largely been insulated from money damage awards in section I 983 actions by decisions giving new force to the eleventh amendment and the doctrine of sovereign immunity. ${ }^{233}$ In a series of decisions ranging from a section 1983 action brought to enjoin a pending state criminal proceeding ${ }^{234}$ to injunctive suits against local executive officials, ${ }^{235}$ the Court has added federalism to equity and comity as standards for determining the availability and scope of federal equitable relief. ${ }^{236}$ Finally, in two cases where state law protected the interests at stake in a federal civil rights action, the Court found that plaintiffs' claims failed to assert any federal right or interest cognizable in a section 1983 suit. ${ }^{237}$

The Court's new sensitivity to asserted state rights and interests seems to reflect a more generalized national mood of distrust of the federal government. The "New Federalism" of President Nixon, the anti-"Washington" rhetoric of the 1976 Presidential election campaign, and the blossoming of the "small is beautiful" philosophy all suggest a widespread public disenchantment with the growth of federal power and a fear that the values of diversity, liberty, and "grassroots democracy" traditionally associated with the federal system may be in jeopardy. ${ }^{238}$

Notwithstanding this apparent emergence of a popular political orientation favoring decentralization and enhanced local autonomy, the Supreme Court's restriction of the availability and scope of federal enforcement of civil rights in the name of federalism is troubling. The Court has repeatedly utilized notions of respect

\footnotetext{
${ }^{232}$ See generally Addresses Delivered at the National Conference on the Causes of Popular Dissatisfaction with the Administration of Justice, 70 F.R.D. 79 (1976).

${ }^{233}$ See, e.g., Edelman v. Jordan, 415 U.S. 65I (1974); City of Kenosha v. Bruno, 412 U.S. 507 (I973); Moor v. County of Alameda, 4II U.S. 693 (I973). See generally pp. II 1 I-97 infra.

${ }^{234}$ See Younger v. Harris, 40 I U.S. 37 (I97I). See generally Part VI, pp. 12841330 infra.

${ }^{235}$ See Rizzo v. Goode, 423 U.S. 362 (1976).

${ }^{236}$ See Younger v. Harris, 40I U.S. 37, 44 (1971). See also Doran v. Salem Inn, Inc., 422 U.S. 922 (1975); Hicks v. Miranda, 422 U.S. 32 (I975); Huffman v. Pursue, Ltd., 420 U.S. 922 (1975).

${ }^{237}$ See Ingraham v. Wright, 45 U.S.L.W. 4364, 4369, 4372 (U.S. April I9, I977); Paul v. Davis, 424 U.S. 693, 697-98, 712 (1976).

${ }^{238}$ See Tribe, Unraveling National League of Cities: The New Federalism and Affirmative Rights to Essential Government Services, 90 Harv. L. Rev. I065, 1068-69 (1977).
} 
for state functions, maintaining the balance between nation and state, and considerations of "Our Federalism," ${ }^{239}$ but has made little apparent effort to fill those open-ended phrases with meaning or demonstrate why such concerns justify a cutback in section 1983 actions. By its own terms, section 1983 is aimed at action taken "under color of state law," and therefore every suit under the statute is one which will necessarily have an impact on the state and compel a state or local government to take action that it would not otherwise have taken. To suggest simply that a renewed concern about federalism compels a jaundiced view of section 1983 could easily lead to another judicial evisceration of the action.

The next Section will isolate certain factors critical to an understanding of contemporary federal-state relations and identify some of the values implicit in the notion of "Our Federalism." After further examining the effect of federal judicial enforcement of civil rights on state autonomy, the Section will attempt to suggest the degree to which a concern for federalism justifies restrictions in the availability and scope of section 1983 .

\section{E. Federalism and Modern Constitutional Theory}

Monroe v. Pape was decided against a background of Supreme Court decisions which had virtually revolutionized the constitutional theory of federal-state relations. The dual federalism analysis which had for a century dominated constitutional thinking and had operated as an external check on federal lawmaking and law-enforcing authority was swiftly interred by a series of Supreme Court holdings validating congressional New Deal legislation. ${ }^{240}$ The theory that the "reserved powers" of the states are to be taken into account in determining the extent of the powers vested in the central government was rejected ${ }^{2+1}$ the tenth amendment pronounced a "truism," ${ }^{242}$ and the plenary authority of the federal government to enact economic and social measures regulating all phases of private conduct affirmed. ${ }^{243}$

${ }^{239}$ See, e.g., Rizzo v. Goode, 423 U.S. 362, 379-80 (1976) ; Mayor of Philadelphia v. Educational Equality League, 4I5 U.S. 605, 6r5 (1974); O'Shea v. Littleton, 4I4 U.S. 488, 499 (1974); Younger v. Harris, 40r U.S. 37, 44 (I97I).

${ }^{240}$ See, e.g., Wickard v. Filburn, 3 I 7 U.S. I I I (1942); United States v. Darby, 312 U.S. I00 (I94I); Steward Mach. Co. v. Davis, 30I U.S. 548 (I937); NLRB v. Jones \& Laughlin Steel Corp., 30I U.S. I (1937).

${ }^{241}$ See, e.g., Wickard v. Filburn, 317 U.S. III, I24-25 (1942); United States v. Darby, 3 I2 U.S. I00, II8-I9 (1942). See generally W. BenNetT, supra note 6, at $204-05$.

242 United States v. Darby, 3 I 2 U.S. I00, I24 (I942).

${ }^{243}$ See generally J. Schmidhauser, supra note 19 , at $184-86$. The main vehicle for the expansion of federal power to regulate private conduct has been the commerce clause. The Supreme Court has read the commerce clause broadly, up- 
The decisions of the post-New Deal era enlarging the authority of the federal government to regulate economic activity and provide directly for individual health and welfare did not for the most part address explicitly the problem of federal action directed at the states themselves. ${ }^{244}$ However, they suggest that the Court had adopted a relatively limited view of the concept of state sovereignty. ${ }^{245}$ Federal substantive lawmaking and administrative authority superseded the states in a wide variety of areas traditionally subject to state control. And taxes and sanctions imposed for the violation of federal regulations were held applicable to state instrumentalities so long as they were incidental to the full implementation of a general federal program. ${ }^{246}$

The Court's fourteenth amendment decisions further support this limited conception of state sovereignty. In the modern era, the amendment has become the vehicle for the creation of farreaching restrictions on the power of state and local governments to regulate the lives of individuals. Even in areas as traditionally associated with state and local control as elementary public education, ${ }^{247}$ domestic relations, ${ }^{248}$ law enforcement, ${ }^{249}$ and voting, ${ }^{250}$

holding federal legislation affecting private conduct so long as the conduct affected could be characterized as either affecting, see, e.g., United States v. Wrightwood Dairy Co., 3 I 5 U.S. I Io (I942); United States v. Darby, 3 I2 U.S. Ioo (I94I); NLRB v. Jones \& Laughlin Steel Corp., 30I U.S. I (I937), or moving through, see, e.g., United States v. Sullivan, 332 U.S. 689 (I948); Mulford v. Smith, 307 U.S. 38 (1939), interstate commerce. Even purely intrastate activity was held subject to congressional control if it fell within a class of conduct that had, in the aggregate, a substantial interstate impact. See, e.g., Perez v. United States, 402 U.S. I46 (I97I); Wickard v. Filburn, 3 I 7 U.S. I I I (I942).

${ }^{244}$ Of course, to the extent that the sovereignty of a state is in part composed of its power to regulate the primary conduct of its citizens, see pp. II79-83 inf:a , the expansion of federal authority during and after the New Deal markedly curtailed state sovereignty.

245 See, e.g., United States v. Appalachian Elec. Power Co., 3 I I U.S. 377, 428 (1940) ("So long as the things done within the state by the United States are valid under [the commerce] power, there can be no interference with the sovereignty of the states."); United States v. California, 297 U.S. I 75, I83-84 (1936) ("The sovereign power of the states is necessarily diminished to the extent of the grants of power to the federal government in the Constitution.").

${ }^{246}$ See, e.g., New York v. United States, 326 U.S. 572, 582 (I946) (plurality opinion); United States v. California, 297 U.S. I75 (I936).

${ }^{247}$ See, e.g., Goss v. Lopez, 4I9 U.S. 565 (I975) ; Swann v. Charlotte-Mecklenburg Bd. of Educ., 402 U.S. I (I97I); Tinker v. Des Moines School Dist., 393 U.S. 503 (1969); Brown v. Board of Educ., 347 U.S. 483 (1954). But see San Antonio Indep. School Dist. v. Rodriguez, 4 I I U.S. I (I973).

${ }^{248}$ See, e.g., Reed v. Reed, 404 U.S. 7 I (I97I); Boddie v. Connecticut, 40I U.S. 37 I (197I) ; Loving v. Virginia, 388 U.S. I (1967); Griswold v. Connecticut, 38r U.S. 479 (1965). But see Sosna v. Iowa, 4I9 U.S. 393 (1975).

249 See, e.g., Benton v. Maryland, 395 U.S. 784 ( I969); Duncan v. Louisiana, 39I U.S. I45 (I968); Gideon v. Wainwright, 372 U.S. 335 (1963). But see Rizzo v. Goode, 423 U.S. 362 (1976).

${ }^{250}$ See, e.g., Katzenbach v. Morgan, 384 U.S. 64I (I966) ; Harper v. Virginia 
the Supreme Court has utilized the fourteenth amendment to impose national standards of fair procedure and equal treatment on states and localities.

Notwithstanding the plenary character of national power in recent decades, the states continue to have constitutional significance. The Constitution presupposes the existence of states and obligates the national government to guarantee to each state a republican form of government, ${ }^{251}$ protection against invasion and domestic violence, ${ }^{252}$ the integrity of state boundaries, ${ }^{253}$ and equal representation in the Senate. ${ }^{25 t}$ Similarly, attributes of sovereignty central to the effective and independent fulfillment of government functions such as "the power [of a state] to locate its own seat of government and to determine when and how it shall be changed from one place to another" ${ }^{255}$ have long been recognized as beyond the power of Congress to restrict or impair. Moreover, the recent decisions in National League of Cities v. Usery ${ }^{256}$ and Oregon v. Mitchell ${ }^{257}$ indicate that the "separate and independent existence of states" ${ }^{258}$ imposes real limitations on the scope of federal power under the commerce clause and the fourteenth amendment.

The broader significance of the Mitchell and National League of Cities holdings is far from clear; in the former case, the opinion of the Court was really that of only one Justice, ${ }^{259}$ while the latter case is the focus of intense scholarly debate. ${ }^{260}$ However, when these cases are viewed in light of the federalism analysis developed over the previous forty years, three principles basic to an under-

Bd. of Elections, 383 U.S. 663 (I966) ; Reynolds v. Sims, 377 U.S. 533 (I964). But see Oregon v. Mitchell, 400 U.S. II2 (1970).

${ }^{251}$ U.S. Const. art. IV, \& 4.

${ }^{252} I d$.

${ }^{253} I d$. art. IV, § 3 .

${ }^{254}$ Id. art. V.

${ }^{255}$ Coyle v. Smith, 22 I U.S. 559, 565 (I9II).

${ }^{256} 426$ U.S. 833 (1976).

${ }^{257} 400$ U.S. II 2 (1970).

${ }^{258}$ Coyle v. Smith, 22 I U.S. 559, 580 (I9II).

${ }^{259}$ At issue in Oregon v. Mitchell were provisions of the Voting Act Amendments of 1970 lowering the voting age to eighteen. By a five-to-four vote, that provision was upheld as applied to federal elections, but by another five-to-four division, the eighteen-year-old vote was held unconstitutional as applied to state elections. Justices Douglas, Brennan, White, and Marshall found it valid as applied to any election; Chief Justice Burger and Justices Harlan, Stewart, and Blackmun thought it entirely invalid; Justice Black cast the deciding vote, holding it constitutional as applied to federal elections but unconstitional as to state elections.

${ }^{260}$ See, e.g., Tribe, supra note 238 ; Michelman, States' Rights and States' Roles:

The Permutations of State "Sovereignty" in National League of Cities v. Usery, forthcoming in the May 1977 issue of the Yale Law Journal; Note, Municipal Bankruptcy, the Tenth Amendment, and the New Federalism, 89 HaRv. L. Rev. I87I (I976). 
standing of the contemporary constitutional theory of federalstate relations and relevant in the context of section 1983 actions may perhaps be discerned:

( I) States are "independent" governments, not simply administrative subdivisions of the national government.

(2) Consequently they must be allowed to perform some of the functions of government and they must be allowed to perform those functions "effectively," free of undue federal impairment.

(3) But there are no specific governmental roles or areas of substantive lawmaking or administrative competence wholly reserved to the states or entirely immune from either federal preemption or the imposition of federal requirements and standards.

Despite the decision in National League of Cities and the resurgence of the Supreme Court's concern over federalism, the third principle, which, insofar as it justifies the imposition of federal constitutional norms of procedural fairness and equal treatment on the adoption and implementation of state policies, is at the core of section 1983 , has in no way been impaired. Although the Court in both National League of Cities and Fry v. United States ${ }^{261}$ sought to limit the hortatory effect of the language in United States v. Darby that the tenth amendment is a "truism," neither case overruled it. ${ }^{262}$ Moreover, National League of Cities, when coupled with the decision in Fitzpatrick v. Bitzer ${ }^{263}$ handed down shortly thereafter, suggests that greater deference will be given to congressional enactments pursuant to the fourteenth amendment which approach the state sovereignty limits to national power than to legislation under the commerce clause -

26142 I U.S. 542 (1975).

262 The tenth amendment has been interpreted as a general "declaration" of the fact that the nature of a federal system and the existence of autonomous states impose limitations on the scope of the power of the national government. See National League of Cities v. Usery, 426 U.S. 833, 842-43 (1976); Fry v. United States, 42 I U.S. 542, 547 n.7 (1975). The National League of Cities Court, however, did not rely on the tenth amendment to justify its conclusion that the r974 amendments to the Fair Labor Standards Act, extending federal minimum wage and maximum hour provisions to state and municipal employees, was unconstitutional. See Tribe, supra note 238 , at 1067 n.r7. In Fry, although the Court pointedly referred to the "significance" of the tenth amendment, it upheld the application of the Economic Stabilization Act of 1970 to state employees, finding that the wage freeze was an emergency measure adopted to counter severe inflation, that its effectiveness would depend on its being made applicable to state employees, and that the measure did not intrude appreciably on state sovereignty. See $42 \mathrm{I}$ U.S. at $547-58 \&$ n.7.

${ }^{263} 427$ U.S. 445 (1976). 
a conclusion which is supported by the purpose and history of the fourteenth amendment. ${ }^{264}$ As a result, the effect of National League of Cities and the "New Federalism" in the section I983 context must be to give greater emphasis to the first and second principles without in any way undermining the third; the current debate over federalism and section I 983 thus emerges as an attempt to reconcile the third principle with the first two. Stated otherwise, the question in the section 1983 context is one of what theoretical limits are imposed by the first principle and what practical ones by the second on the power of the federal government - and particularly the federal courts - to assume the role of the definer and enforcer of constitutional norms according to the third principle.

I. The First Principle: States as Governments. - The notion of states as "independent" governments implies certain limits on the power of the federal government both to preempt and to review the decisions of sovereign states. As a general matter, it should be noted that these constraints need not derive solely from the peculiar characteristics of states per se; rather, the imposition of limits - or the existence, in fact, of practical deference - may be at least partly due to the fact that the state process in question constitutes a separate system or entity performing certain important functions within the society as a whole, and that an adequate and efficient level of performance may require the minimization of outside intrusions. This respect, or comity, accorded the separate state system is without reference to whether the entity is a "state" or another corporate body, such as the Army. ${ }^{265}$ For the purposes of section 1983 , the critical inquiry necessarily revolves around the prerogatives of the states to define through their own legislatures and courts the rights of citizens and the duties and obligations of government. It is an inquiry which cannot be resolved by reference to precedent alone; while the decisions in Coyle v. Smith

${ }^{264}$ See pp. II $44-46$ supra. In Fitzpatrick, the Court considered the validity of the 1972 amendments to title VII of the Civil Rights Act of 1964, which authorized federal courts to order attorneys fees and money damage awards against state governments and in favor of private individuals in cases where unlawful employment discrimination had been proven. Finding that the legislation had been enacted pursuant to Congress' authority under $\S 5$ of the fourteenth amendment to enforce the limitations on state sovereignty embodied in that amendment, the Court rejected claims that the title VII awards violated the eleventh amendment or unconstitutionally infringed on state sovereignty. See 427 U.S. at $452-57$ \& n.9.

${ }^{265}$ See, e.g., Schlesinger v. Councilman, 420 U.S. 738, 754-57 (1975) (finding that "considerations of comity, the necessity of respect for coordinate judicial systems," require that federal district courts be barred from enjoining or otherwise interfering with military court-martial proceedings). See also Younger v. Harris, 40I U.S. 37 (I97I). 
and National League of Cities v. Usery indicate that the Supreme Court has placed within a protected core of state sovereignty decisions as to the location of the seat of government and the wages state employees are to be paid, these decisions - particularly the latter - are ambiguous as to the state interest deserving protection or the means by which one can determine whether a given decision is inside or outside of any core. Rather, this inquiry must be resolved in light of the values and traditions of our federalist system which are expressed in - but not confined to - prior decisions of the Supreme Court.

The power to govern at least some aspects of state-citizen relations, it could be argued, should be deemed an essential attribute of state sovereignty and one of the premises of a federal union. The strengths of federalism are said to be that in providing for the decentralization of decisionmaking and administration, it assures citizens increased access to government, provides an opportunity for the development of policies and programs responsive to local differences and needs, and secures benefits for the nation as a whole by enabling the states to serve as places of experimentation - "laboratories of ideas." ${ }^{266}$ This conception of political decentralization as the key to the preservation of diversity and of a government attuned to local values and problems has been considered particularly compelling in the United States, given the political and cultural heterogeneity of the American people and the traditional focus on the community as the center of political and social life.

Such a view of the positive role of states and localities has found increased expression in recent decisions of the Supreme Court. The Court has displayed a greater degree of deference to referendums and other forms of state and local government decisionmaking designed to distill and reflect the particular will of local majorities. ${ }^{267}$ Indeed, in Village of Belle Terre v. Boraas, ${ }^{268}$ the Court apparently gave dispositive weight to a community's right to define its own character and values in upholding an ordinance which effectively excluded from the community persons whose lifestyle it found not in keeping with its character. ${ }^{269}$ Sim-

${ }^{266}$ See generally R. LeAch, supra note 6 , at $57-82$; Benson, Values of Decentralized Government, in EsSAYS IN FEDERALISM I (Institute for Studies in Federalism 1961); Merriam, Federalism in Transition: The Dynamics of Change and Continuity, in The Uneasy Partnership 5 (R. Feld \& C. Grafton eds. 1973).

${ }^{267}$ See, e.g., City of Eastlake v. Forest City Enterprises, 426 U.S. 668 (I976); James v. Valtierra, 402 I37 (I97I).

${ }^{268} 4$ I 6 U.S. I (I974).

${ }^{269} I d$. at 9 (village ordinance restricting land use to one-family dwellings, where the word "family" is defined to exclude groups of more than two unrelated persons, held constitutional; police power may be exercised to create "zones where 
ilarly, the Court has turned to "community standards" in determining the scope of protection afforded by the first amendment to assertedly obscene forms of expression. ${ }^{270}$ Finally, in a related vein, the language of the recent Paul v. Davis ${ }^{271}$ and Ingraham v. Wright ${ }^{272}$ decisions emphasizing the availability of state causes of action to vindicate the personal liberty interests threatened by the challenged state action while denying the existence of any federal claim suggests an enhanced willingness to view the state as an integral unit and to defer to its judgment on individual deprivations at least until the state courts have had an opportunity to apply state law. ${ }^{273}$

Inevitably, decisions such as these involve value judgments as to where to draw lines between federal and state power. These judgments are necessarily based on assessments of the values attaching to state decisionmaking and the needs for federal intervention. But while this may render objective criticism more difficult, there is ample reason to suppose that any federalism-based benefits secured by the inclusion of the processes of articulating and enforcing constitutional norms within a core of state sovereignty are substantially outweighed by the dangers presented by such an approach.

The vision of the nation as a collection of small communities, each characterized by values and common interests shared within but distinct from those of other communities, has been of diminishing vitality almost since the birth of the Republic. The development of a national economy and modern means of transportation and communication have served to knit the various communities together and to contribute to the formation of a national community with shared national values. Moreover, the constitutional revolutions in the middle of the nineteenth and twentieth centuries established, particularly in the area of civil rights, the primacy of that national community and of those national constitutional norms. The Civil War may be seen as having affirmed the supremacy of the nation over the states, while the fourteenth amendment, although a "moderate" enactment, guaranteed a

family values, youth values, and the blessings of quiet seclusion and clean air" may be secured).

${ }^{270}$ See, e.g., Miller v. California, 4I3 U.S. I5 (I973).

271424 U.S. 693 (I976).

27245 U.S.L.W. 4364 (U.S. April I9, 1977).

${ }^{273}$ See id. at 4369 (cruel and unusual punishment clause of the eighth amendment does not apply to disciplinary corporal punishment in public schools, in part because of the existence of civil and criminal law constraints of teachers and administrators) ; Paul v. Davis, 424 U.S. 693, 697-70I (1976) (injury to reputation by police officer held not to state a claim for violation of the due process clause of the fourteenth amendment; language of the opinion points to the existence of state tort law of defamation remedies). 
federal presence to ensure that state standards complied with minimal national requirements of equal treatment and procedural fairness. ${ }^{274}$ In this century, the fourteenth amendment has become the vehicle for the virtual nationalization of the function of articulating and enforcing civil rights.

To be sure, some might view the nationalization of civil rights as fundamentally inconsistent with a concern for federalism. But while the allowance of local diversity and the shaping of government decisions in response to local interests and needs may be considered among the strengths of federalism, the dangers of emphasizing these values in the civil rights context are manifest. As political scientists from Madison on have noted, the ability of small but well-organized groups to gain control of the levers of government and use its power to oppress others is maximized in smaller units. ${ }^{275}$ One of the virtues that Madison saw in the Federal Constitution was that in creating a national government over a large territory, it reduced the danger of domination by "faction." ${ }^{276}$ Moreover, the value of states as laboratories for experimentation in the context of defining and protecting civil rights seems questionable. As the development of the incorporation doctrine illustrates, where certain principles of fundamental fairness are at stake, such as the right to counsel or the protection against unreasonable searches and seizures, there may be only one, necessarily national standard adequate to ensure full protection of the personal interest at stake. If experimentation is to be tolerated, it must take place above this threshold. ${ }^{277}$

Indeed, regardless of whether the ability to define the mutual rights and obligations of citizens and government is a necessary attribute of sovereignty, the fact remains that a national community adhering to national constitutional values has effectively stripped the states of much of their function in the definition of civil rights. ${ }^{278}$ This national assumption of the civil rights function may well suggest that, given the supremacy clause and the fourteenth amendment, the states are not truly "sovereign," as that term is used in describing independent nations, but only relatively autonomous governments subject to the actual sovereignty

${ }^{274}$ See pp. I144-46 supra.

${ }^{275}$ See The Federalist No. io (J. Madison); G. McConnell, Private Power ANd American Democracy IO7-I8 (Ig66); Note, supra note 9, at IO22-24, IO2933 .

${ }^{276}$ See The Federalist No. io (J. Madison); Diamond, The Federalist's View of Federalism, in EsSays IN FEDERALISM 2I, 52 (Institute for Studies in Federalism r $96 \mathrm{r}$ ).

${ }^{277}$ See, e.g., Brennan, State Constitutions and the Protection of Individual Rights, 90 HARV. L. REv. 489 (1977).

${ }^{278}$ See, e.g., W. Bennet, supra note 6, at 2I2-I4; M. Reagan, The New FedERALISM I2-I3 (I972). 
of the nation. ${ }^{279}$ This does not mean that the interests of states are irrelevant to the definition and enforcement of civil rights; even to offer such a suggestion would be to ignore recent trends in the Supreme Court. What it does suggest is that efforts to define at a theoretical level the limits of federal authority in the civil rights area on the basis of state sovereignty may be a task that is both virtually impossible and constitutionally unnecessary. Instead, attention might better be focused on a more practical effort to accommodate the federal interest in articulating and enforcing constitutional norms with the legitimate interests of the state in its continued effective functioning - that is, the accommodation of the second and third principles.

2. The Second Principle: Effectiveness. - The thrust of the second principle appears to be that federal agencies - the lower federal courts where section 1983 is concerned - must not exercise power in a fashion which undermines the ability of states and localities to perform the functions they have assumed or effectively displaces them from roles for which they remain formally responsible. At least in part, this principle may respond to deeply felt concerns for fair play and accountability. Surely, it is perceived as unfair, if not wasteful, to allow a state or municipality to shoulder certain financial burdens and pursue time-consuming policymaking procedures if in the end federal requirements and standards so hamstring state and local efforts that they cannot achieve their legitimate goals. More significantly, in a system in which one level of government is ostensibly responsible for certain functions and services but has been either effectively displaced or rendered unable adequately to perform its role, the goal of government accountability to the citizens it serves is frustrated.

To a considerable extent, however, the conception implicit in this principle of federal involvement in state activities as an "interference" or "intrusion" - a conception which finds expression in many of the Supreme Court's recent decisions restricting the availability and scope of section 1983 - is mistaken. The concerns underlying this notion were perhaps best articulated by Justice Black in Younger v. Harris, ${ }^{280}$ where he contended that restraints must be imposed on federal equitable relief to ensure that

${ }^{279}$ See, e.g., Fitzpatrick v. Bitzer, 427 U.S. 445, 455-66 (I 976) (Rehnquist, J.) (the Civil War amendments sanction federal intrusion "into the judicial, executive, and legislative spheres of autonomy previously reserved to the States [and] ... a corresponding diminution of state sovereignty"); Ex parte Virginia, Io U.S. 339, 345-48 (1880) ("The prohibitions of the Fourteenth Amendment are directed to the States, and they are to a degree restrictions of State power.... [Their] enforcement is no invasion of State sovereignty.").

${ }^{280} 40$ I U.S. 37 (I97I). 
"the States and their institutions are left to perform their separate functions in their separate ways." ${ }^{281}$ The model of federalism implicit in this statement is that of the "layer cake" - the traditional notion that the nation and the states constitute "two governments covering the same ground yet distinct and separate in their actions." ${ }^{282}$ Not only is this model inconsistent with constitutional doctrine which has developed since the erosion of "dual federalism" analysis, but it is also completely alien to contemporary political theory. The metaphor suggested by the late Professor Morton Grodzins and subsequently adopted by most contemporary students of American government is the "marble cake":"283 no important function of government is the exclusive province of one of the levels; rather federal, state, and local governments are actively involved in virtually all functions of government, and federal-state cooperation, not separation, is characteristic. ${ }^{284}$

The cutting edge of this new model of federal-state relations has been the federal grant-in-aid. ${ }^{285}$ The inability of state and local governments to finance all the services sought by their citizens has led to increasing reliance on Washington for financial support. ${ }^{286}$ The grant program, however, has significantly undermined state and local autonomy in a number of respects. First, a

${ }^{281} I d$. at 44 .

${ }^{282}$ See i J. Bryce, The American Commonwealth 432 (i888). See also Tarble's Case, 80 U.S. ( 13 Wall.) 397, 406 (I87I) ("There are within the territorial limits of each state two governments, restricted in their sphere of action, but independent of each other, and supreme within their respective spheres. Each has its separate departments, each has its distinct laws . . . Neither government can intrude within the jurisdiction of the other . . . .").

${ }^{283}$ See M. Grodzins, The American System 8 (D. Elazar ed. 1966). See also R. LEACH, supra note 6 , at I4; M. REAGAN, supra note 278 , at 6 .

${ }^{284}$ See generally M. GrodzIns, supra note 283 ; R. LEACH, supra note $6 ; \mathbf{M}$. ReAGAN, supra note 278; Sundquist \& Davis, The Problem of Coordination in a Changing Federalism, in The Uneasy Partnership 24 (R. Feld \& C. Grafton eds. I 973 ).

${ }^{285}$ See generally M. Grodzins, supra note 283 , at 60-70; M. REAGAN, supra note 278 , at $54-97$.

${ }^{286}$ See generally Advisory Comm'n on Intergovernmental Relations, Restoring Fiscal Balance in the Federal System, in The Uneasy PartNership 55 (R. Feld \& C. Grafton eds. I973) ; R. LEACH, supra note 6, at 194-220; M. REAGAN, supra note 278 , at $8,3 \mathrm{I}-53$. The fact of increasing popular reliance on the federal government for the supply of essential services has also been attributed to the structural weaknesses characteristic of most state governments, see Committee for Economic Development, Modernizing State Government, in The UNEASy PARTNershIP 9I (R. Feld \& C. Grafton eds. 1973); Citizens Conference on State Legislatures, State Legislatures in the Seventies, in id. at 99 ; R. LEACH, supra note 6, at II5-42; G. MCConnell, supra note 275 , at $166-95$, and on the slowness with which many state governments responded to demands for increases in services, see W. BENNETr, supra note 6 , at 2 18-19. 
cardinal rule governing the acceptance of federal grants-in-aid has been that federal regulatory authority follows federal money; ${ }^{287}$ as a precondition to federal grants, the government has mandated basic changes in state and local administrative structures and personnel policies, as well as minimum standards for the provision of services. ${ }^{288}$ Second, state policy and budgetary decisions have been substantially affected by the fact that most federal money has been disbursed in the form of categorical grants, restricting often quite narrowly the purposes to which the funds can be put. ${ }^{289}$ This effect is further exacerbated where federal money is given in the form of matching grants, which induce states and localities to adopt federal spending priorities. While the substitutions of general federal revenue sharing for more specific categorical grants reduces federal involvement in local policy and budgetary decisions, general federal regulatory control over local administrative and personnel procedures has continued. ${ }^{290}$

Of course, to deny that the states in fact perform any "separate functions" is not to suggest that they have been reduced to nonentities. States and localities continue to have an important role in designing and implementing government policies, with the federal government relying on state and local governments for the provision of many social services. The result has been characterized as "cooperative federalism" ${ }^{291}$ — a system of complex interaction among federal, state, and local governments which reflects their mutual dependencies. ${ }^{292}$

The heavy involvement of the federal government in the state provision of services in areas as traditionally local as education, law enforcement, and welfare suggests that any federalism-based concern that section 1983 actions impair the ability of states to carry out their "separate functions" must be misplaced. ${ }^{293}$ Given the extensive degree of federal-state interaction in all phases of government, a legitimate federal concern may be seen as in operation in all traditionally local areas. Moreover, section 1983 tracks the characteristic mode of federal involvement with local government, for, as in the programmatic and policy restrictions imposed as a consequence of the acceptance of federal grants-inaid, suits brought under section 1983 operate primarily to enforce

\footnotetext{
${ }^{287}$ See Oklahoma v. United States Civil Serv. Comm'n, 303 U.S. 127 (1947);

J. SCHMidhauser, supra note 19 , at 189-90.

${ }^{288}$ See, e.g., M. GrodzINs, supra note 283 , at 64 , 68-69; M. REAGAN, supra note 278 , at 57 .

${ }^{289}$ See M. ReAGan, supra note 278, at 59-66.

${ }^{290}$ See generally id. at 89-144.

${ }^{291}$ See R. LEACH, supra note 6, at 14.

${ }^{292}$ See generally id. at 57-82.

${ }^{293}$ See, e.g., M. GrodzINs, supra note 283 , at $89-\mathrm{I} 55$; R. LEACH, supra note 6 , at $83-\mathrm{II}_{4}$.
} 
national requirements and standards - in this case constitutional norms - on local legislative and administrative decisionmaking rather than as a full-scale displacement of local substantive authority.

An awareness of the already considerable federal role in the state and local provision of essential services and the regulation of primary conduct may thus mitigate concerns that federal civil rights actions, merely because they involve federal institutions in local affairs, constitute an impairment of the states' ability to function effectively. In the context of section r 983 actions, however, the federal involvement is judicial rather than executive or legislative, a distinction which necessarily adds another dimension to the analysis.

On the one hand, it has been the traditional view that judicial determinations have less impact in shaping the conduct of government than legislative or executive measures. ${ }^{294}$ The "least dangerous branch," as Alexander Hamilton characterized the federal courts, ${ }^{295}$ has no control over "either the sword or the purse." 296 Moreover, both the scope of judicial determinations and the opportunity for judicial influence on social policy are largely beyond the control of judges to expand. Courts can act only on those cases and issues presented to them by litigants, and they can bind only those litigants involved in the case before them. ${ }^{297}$ Indeed, as has already been suggested, ${ }^{298}$ this sense of the limited nature of judicial action may explain the decision of the Republicans during the Reconstruction era to entrust civil rights enforcement to the courts.

Nonetheless, section 1983 suits may pose a greater threat to state and local effectiveness than other forms of federal regulatory policy. ${ }^{299}$ Many of the factors Professor Wechsler identified as the "political safeguards of federalism" - including the role of the states in the composition and selection of the national government, which often leads members of Congress and, to a lesser extent, the President, to act with an awareness of state prerogatives and interests - seem attenuated if not absent in the context of

${ }^{294}$ See Chayes, The Role of the Judge in Public Law Litigation, 89 Harv. L. REV. I 28 I, I282-83 (I976).

295 The Federalist No. 78, at 465 (A. Hamilton) (C. Rossiter ed. I96I).

${ }^{296}$ Id. at 465-66. See generally A. Cox, The Role of the Supreme Court

in American Government ro3-04 (i976).

${ }^{297}$ See Chayes, supra note 294 , at $1282-83$.

${ }^{298}$ See pp. II $52-53$ supra.

${ }^{299} \mathrm{Cf}$. Tribe, supra note ${ }^{64}$ (Congress, because of its representative character, may override states' eleventh amendment immunity more legitimately than may the courts). 
federal judicial action. ${ }^{300}$ At best, federal judges are one step further removed from the states than the President and Senators who appoint and confirm them. Moreover, many of the indirect controls which maximize local input in the formulation and effectuation of federal policies may be absent in federal court adjudication. There would certainly appear to be less opportunity for the kind of intergovernmental lobbying leading to compromise and adjustment which characterizes the framing of most federal economic and social policies affecting states and municipalities. Indeed, that a judicial determination is "legal" rather than "political" not only seems to preclude a role for the affected state officials in determining whether the challenged law or conduct violates the Constitution but also renders illegitimate techniques of noncompliance or indirect resistance through which state and local officers may be able to shape the implementation of federal policy directives.

This traditional model of federal-state relations in the context of federal court adjudication, however analytically useful where damage suits are concerned, begins to break down when one considers those actions which are most often thought to threaten the functioning of the state - the modern injunctive suit. ${ }^{301}$ In a growing number of section 1983 injunction suits, plaintiffs have requested and federal courts have ordered systemic relief resulting in sweeping displacements of local decisionmaking and administration and substitution of federal judicial authority. ${ }^{302}$ Even in

${ }^{300}$ See H. Wechsler, The Political Safeguards of Federalism, in Principles, Politics and Fundamental Law 49, 54-56, 64-82 (i96i); The Federalist No. 45, at 29I (J. Madison) (C. Rossiter ed. I96I). The notion of the "political safeguards of federalism" may be open to question even in the context of the legislative and executive branches. State concerns with respect to a given issue may not be uniform throughout the country, so that federal legislation intruding deeply on the functions of one state may be passed despite that state's objections; a state's interests may not be accurately represented by its congressional delegation because representatives' actions with regard to any given issue may be dictated by diverse political pressures distorting their advocacy of the state's position; a state's interest may not be monolithic or easily discernable, and representatives may disagree as to their state's interest in a given issue; finally, the power of state legislatures to compel accountability from their congressional delegations has been eroded both by the seventeenth amendment, providing for popular election of Senators, and by Supreme Court reapportionment decisions, see, e.g., Kirkpatrick v. Preisler, 394 U.S. 526 (I969); Wesberry v. Sanders, 376 U.S. I (1964), rendering the districting process largely mechanical. See Note, supra note 260 , at $1885 \&$ n.II7.

${ }^{301}$ See pp. I227-50 infra. See generally Chayes, supra note 284 ; D. Horowitz, The Courts and Social Policy (r977); O. Fiss, Injunctions 3i5-8i (1972).

${ }^{302}$ See, e.g., Wyatt v. Stickney, 344 F. Supp. 373 (M.D. Ala. I972) (granting relief); 344 F. Supp. 387 (M.D. Ala. 1972) (modifying relief), enforcing 325 F. Supp. 78I (M.D. Ala. I97I), aff'd in part and remanded in part sub. nom. Wyatt 
areas like education ${ }^{303}$ and law enforcement, ${ }^{304}$ which have traditionally been viewed as the particular responsibilities of state and local governments, courts have eschewed the narrow role assigned to them by the traditional model and, on finding a constitutional violation, have assumed relatively extensive power to redress the resulting harms. ${ }^{305}$ And in ordering states or municipalities to take or refrain from certain actions, or to develop new programs, the federal courts have imposed costs which necessarily have the effect of limiting the range of government activity in areas not directly at issue in the section 1983 suit. $^{306}$

Yet the breadth of the remedy sought in the modern section I 983 injunction action, for all that it might seem to betoken a major disruption of the local delivery of services and the effective performance of local government functions, may in fact enhance the ability of state and local units to influence federal civil rights enforcements. Although lobbying or negotiation may still be inappropriate in the initial liability-determining stage, in injunctive suits - as opposed to damage actions - the issue of liability no longer so completely dominates the suit, ${ }^{307}$ and the award of a

v. Alderholt, 503 F.2d 1305 (5th Cir. 1974) (extensive court reform of state mental hospitals); Rhem v. Malcolm, 507 F.2d 333 (2d Cir. 1974) (affirming lower court finding of violation and remanding for adjustment of remedy); 527 F.2d 104 I (2d Cir. I975) (affirming modified relief) (reform of pretrial detention facilities); Morgan v. Kerrigan, 40I F. Supp. 216 (D. Mass.), aff'd, 530 F.2d 43 I (Ist Cir. I975), cert. denied, 426 U.S. 935 (I976) (wide-ranging plan for integration of Boston public schools), enforced, 409 F. Supp. II4I (D. Mass. 1975), aff'd sub nom. Morgan v. McDonough, 540 F.2d 527 (Ist Cir. I976) (receivership of Boston high school); Holt v. Sarver, 442 F.2d 304 (8th Cir. 197I); 505 F.2d I94 (8th Cir. 1974) (reform of state prison system).

${ }^{303}$ See, e.g., Swann v. Charlotte-Mecklenburg Bd. of Educ., 402 U.S. I (I97 I) (broad power of federal courts to fashion remedial decrees in school integration cases); Morgan v. Kerrigan, 530 F.2d 43 I (Ist Cir. 1975), cert. denied, 426 U.S. 935 (1976) (school integration), discussed at pp. 1236-39 infra.

${ }^{304}$ See, e.g., Lewis v. Kugler, 446 F.2d ${ }_{3} 43$ (3d Cir. 197I) (injunction against police practice of halting and searching long-haired highway travelers); Lankford v. Gelston, 364 F.2d I97 (4th Cir. 1966) (en banc) (injunction against widescale illegal searches of citizens' homes); Calvin v. Conlisk, 520 F.2d I (7th Cir. 1975 ), vacated and remanded, 424 U.S. 902 (1976).

${ }^{305}$ See pp. I227-3 I infra; cases cited notes 303 \& 304 supra.

${ }^{306}$ See, e.g., Rhem v. Malcolm, 507 F.3d 333, 340-4 I (2d Cir. 1974) (cost of compliance with affirmative injunction is burden to city in throes of fiscal crisis and facing hard policy choices with regard to cutbacks in other municipal services), discussed at pp. 123I-36 infra. See D. HorowItz, supra note $30 \mathrm{I}$, at 6-7. In Edelman v. Jordan, 415 U.S. 667 (1974), the Supreme Court, explicitly recognizing that while most affirmative injunctions run in name against state officials, they impose substantial costs on the government itself, id. at 667-69, carved out an exception to the states' eleventh amendment immunity for costs which are "the necessary result of compliance in the future with a substantive federal-question determination." Id. at 669 .

${ }^{307}$ See Chayes, supra note 294 , at I293-94, I302. The point is well illustrated 
specific remedy no longer follows so automatically from a decision of the merits. ${ }^{308}$ Rather, the question of liability has become in large measure a trigger for an exhaustive search for the appropriate remedy. ${ }^{309}$ Given the broad range of potentially available remedies, ${ }^{310}$ the selection of a particular remedy, although influenced by established principles of equity, becomes a discretionary decision; as a result, attempts by local government officials to influence the final decree no longer appear illegitimate. ${ }^{311}$ To the extent that such participation occurs - and the recent work of Professor Chayes indicates that local input is increasingly welcomed at the relief stage ${ }^{312}$ - fears about the "intrusiveness" of federal judicial action and of the danger it poses to the continued effectiveness of state and local institutions may be allayed.

In summary, the principle of assuring state and local effec-

by cases in the area of school integration, where the Supreme Court first articulated the principle that segregated school systems are unconstitutional, see Brown v. Board of Educ., 347 U.S. 483 (1964), and then, in a later opinion in the same case, see 349 U.S. 294 (1955), and in subsequent cases, see, e.g., Swann v. CharlotteMecklenburg Bd. of Educ., 402 U.S. I (197I), fashioned standards for implementation of the right to integrated schools, recognizing that the "scope of a [federal] ... court's equitable powers to remedy past wrongs is broad, for breadth and flexibility are inherent in equitable remedies," $i d$. at 15 .

${ }^{308}$ See, e.g., Swann v. Charlotte-Mecklenburg Bd. of Educ., 402 U.S. I (1971):

Once a right and a violation have been shown, the scope of a district court's equitable powers to remedy past wrongs is broad, for breadth and flexibility are inherent in equitable remedies.

"The essence of equity jurisdiction has been the power of the Chancellor to do equity and to mould each decree to the necessities of the particular case. Flexibility rather than rigidity has distinguished it. The qualities of mercy and practicality have made equity the instrument for nice adjustment and reconciliation between the public interest and private needs as well as between competing private claims."

Id. at ${ }_{5}$ (quoting Hecht Co. v. Bowles, 321 U.S. 32I, 329-30 (1944)). See also Chayes, supra note 294, at I298-1304; O. Fiss, supra note 301, at 92; K. PARKER, MOdern Judicial Remedies I83-252, 264-78 (1975); pp. I247-50 infra.

${ }^{309}$ Compare, e.g., Wyatt v. Stickney, 325 F. Supp. 78I (M.D. Ala. 197I) (holding that mental patients in state facility have constitutional right to treatment), with Wyatt v. Stickney, 344 F. Supp. 373 (M.D. Ala. 1972) (granting relief); 344 F. Supp. 387 (M.D. Ala. 1972) (modifying relief) (enforcing right identified in earlier opinion), aff'd in part and remanded in part sub nom. Wyatt v. Alderholt, 503 F.2d 1305 (5th Cir. 1974). See also Note, The Wyatt Case: Implementation of a Judicial Decree Ordering Institutional Change, 84 YALE L.J. I338 (1975); Chayes, supra note 294, at 1298-1304; pp. 1227-50 infra.

${ }^{310}$ See generally O. FISs, supra note 301 , at 4 I8-83; K. PARKER, supra note 308 , at I2-20, 185-206, 264-78; Chayes, supra note 284, at I298-1304; Note, Monitors: A New Equitable Remedy, 70 YALE L.J. I03 (1960).

${ }^{311}$ See Chayes, supra note 294, at I284, I298-1308. Indeed, federal court deference, initially, to local government officials in the shaping of relief has characterized the decree formulation process in most cases ordering affirmative injunctive relief. See pp. 1227-50 infra.

${ }^{312}$ See Chayes, supra note 294 , at 1284 , I298-1308. 
tiveness in performing the functions those units of government have assumed is not necessarily impaired by section 1983 suits. Even without section 1983 , virtually all state and local government services and functions are to a considerable degree intertwined with and regulated by federal legislation and federal agencies. $^{313}$ Moreover, at least in the damage action context, the federal intrusion into state affairs is a narrow one, limited to adjudicating the claim of the particular plaintiff and leaving plenary operational authority to the existing state and local agencies. ${ }^{314}$ Finally, in the more potentially disruptive systemic injunctive suit, mechanisms for securing the participation of affected local interests in the formulation and implementation of the decree may be developed and, in assuring the acceptability and workability of the remedy eventually ordered, may become a means for reconciling the respective federal civil rights and local administrative concerns implicated by section 1983 actions. Thus, as it emerges from this analysis, the cutting edge of the contemporary concern for federalism in the context of section I 983 actions assumes the form of an obligation placed on commentators and federal judges to develop principles that will facilitate the fashioning of forms of injunctive relief which will best accommodate the vindication of constitutional rights to the need for assuring the continued effectiveness of state and local government units. ${ }^{315}$

\section{Substantive Limits on Liability and Relief}

Although Congress, in enacting section 1983 , intended major changes in the structure of relationships among citizens, states, and the federal government, the legislative history and the political theory of the times indicate that neither section 1983 nor the fourteenth amendment was intended to abolish the states or

${ }^{313}$ See pp. II 75-80, II $83-86$ supra.

${ }^{314}$ Under the Supreme Court's holding in Monroe v. Pape, 365 U.S. I67 (r96r), local government units are not "persons" for purposes of $\S$ r983 and thus may not be held directly liable for damages for constitutional deprivations inflicted by their employees. See pp. I19r-97 infra. While an open-ended damage liability for public officials under $\S \mathrm{I} 983 \mathrm{might}$ operate to work an interference with governmental operations, either by unduly inhibiting the discretion of public official defendants or deterring prospective public officeholders from seeking government positions, the state of mind requirements and immunity rules adopted by the courts for $\$ 1983$ damage actions minimize such a danger. See pp. I204-1 7 infra.

${ }^{315}$ For discussion of possible techniques for achieving such accommodations, see pp. $1240-50$ infra. 
effect their total subordination to the federal government. ${ }^{1}$ Perhaps even in $187 \mathrm{I}$, it was assumed that the statute would not be given the enormous scope that its open-ended language suggests that it is capable of sustaining. In any event, the federal courts in the late nineteenth century through narrow intepretations of the constitutional rights protected by the statute and of the concept of "under color" of state law successfully restricted the scope of the statute. ${ }^{2}$ This judicial effort to develop limiting notions to cabin section 1983 has to a considerable extent been recapitulated in the aftermath of Monroe v. Pape. ${ }^{3}$ In the last two decades, however, the focus of judicial attention has shifted from the problems of the rights protected and state action - which have largely been assumed to be coterminous with the fourteenth amendment - to the other components of the section I 983 prima facie case. This Part will examine three means which modern federal courts have used to limit the scope of section 1983 : the restrictive definition of the type of "person" suable under the statute; the development of state of mind requirements requisite to finding of liability; and the creation of limits on the availability of effective relief once liability has been found.

\section{A. Defining a "Person" Under Section 1983}

I. Municipal and Governmental Immunities. - The Supreme Court's holding in Monroe v. Pape ${ }^{4}$ that municipalities are immune from suit under section 1983 was based solely on an examination of legislative history. Relying on the House of Representatives' rejection of the "Sherman Amendment," ${ }^{5}$ which would have held municipalities liable for damages to any citizen deprived of constitutional rights by acts of violence, ${ }^{6}$ congressional doubts as to the constitutionality of that amendment, ${ }^{7}$ and a reaction it characterized as "so antagonistic" that it strained credulity to believe Congress intended municipalities to be liable, the Court struck them from the definition of "person" for I 983 purposes. ${ }^{8}$ Although only months after passage of section I 983 ,

${ }^{1}$ See pp. II41-56 supra.

${ }^{2}$ See pp. II 56-61 supra.

${ }^{3} 365$ U.S. 167 (1961).

${ }^{4}$ Id. at $187-92$.

${ }^{5}$ See id. at 188; Cong. Globe, 42 d Cong., Ist Sess. 663 (1871).

${ }_{3}^{6} 65$ U.S. at $\mathrm{r} 88-89$ \& $\mathrm{nn} .38$ \& $4 \mathrm{I}$.

${ }^{7}$ Id. at I9o. See Cong. Globe, 42 d Cong., ist Sess. 804, 820-21 (I87I). The Senate apparently entertained no such doubts, for it passed the amendment, which was dropped in conference. See 365 U.S. at I88-90; Cong. GLOBE, 42 d Cong., Ist Sess. 704-05, 804 (1871).

${ }_{3} 6_{5}$ U.S. at r 9 r. 
Congress enacted a statute defining "person" to "extend and be applied to bodies politic and corporate," ${ }^{9}$ the Court noted that that definition was "merely an allowable, not a mandatory, one." 10

Monroe's review of the legislative history is highly questionable. First, the debates involved no explicit discussion of the definition of the word "person." ${ }^{11}$ Second, the penalties provided by the Sherman Amendment went well beyond those of section 1983: the amendment would have made each citizen of every municipality, as well as the municipality itself, strictly liable for violence perpetrated by other citizens regardless of whether or not they acted under color of state law. ${ }^{12}$ And while the second version of the amendment lessened liability somewhat by exempting citizens from liability and by providing for municipal compensation only where a judgment against a culpable private citizen went unsatisfied, ${ }^{13}$ there may well have been considerable congressional opposition to the notion that municipalities should be liable at all for acts of private citizens, ${ }^{14}$ especially given that in I 87 I law enforcement was largely a state, not a local, function; to hold municipalities liable for failure to perform acts not within their responsibility was undoubtedly viewed as unjust. ${ }^{15}$ At best, the legislative history is ambiguous with respect to the liability of municipalities for actions taken under color of law, and some analysis of the purposes and policies underlying section 1983 would seem to have been necessary to support the Monroe conclusion. ${ }^{16}$

${ }^{9}$ Act of Feb. $25, \mathrm{r} 87 \mathrm{I}$, ch. $7 \mathrm{I}, \S 2$, I6 Stat. $42 \mathrm{I}$. The present code provision does not apply as broadly. See I U.S.C. \& I (1970).

${ }^{10} 365$ U.S. at r $190-9 \mathrm{r}$.

${ }^{11}$ See id. at 187-92; Kates \& Kouba, Liability of Public Entities Under Section 1983 of the Civil Rights Act, 45 S. CAL. L. Rev. I31, I32-33 (1972).

${ }^{12}$ See Monroe v. Pape, 365 U.S. I67, I88 n.38 (1961) ; Cong. Globe, 42d Cong., Ist Sess. 663 (I87I).

${ }^{13} 365$ U.S. at 188 n.4I ; Cong. Globe, 42 d Cong., ist Sess. 749 (187r). It was this version that was the focus of most of the congressional debate. See Note, Damage Remedies Against Municipalities for Constitutional Violations, 89 HARv. L. REv. 922 , 947 n.I32 (1976).

${ }^{14}$ See Cong. Globe, $42 \mathrm{~d}$ Cong., ist Sess. 788-89, 794 (1871). As one commentator has noted, rejection of the Sherman Amendment can stand only for the proposition that Congress did not wish to impose strict liability on governmental units for acts by private citizens. See Note, Developing Governmental Liability Under 42 U.S.C. \$ I983, 55 MINN. L. REv. I20I, I205 (1971). See also Note, supra note I3, at $946-49$.

${ }^{15}$ See Cong. Globe, 42d Cong., ist Sess. 788, 792-93, 795 (I87i); President's Comm'n on Law Enforcement and the Administration of Justice, Task Force RePort: The Police 5-6 (1967) (as of I87I, only large cities had police forces).

${ }^{16}$ See generally Kates \& Kouba, supra note II; Note, supra note I4; Note, 
Following Monroe, section I 983 plaintiffs pursued a number of strategies in attempts to hold municipalities accountable. The most significant was an attempt to limit Monroe to suits for damages. While a number of lower courts accepted this reliefbased distinction and found Monroe inapplicable to prayers for injunctive relief ${ }^{17}$ the Supreme Court flatly rejected a bifurcated approach to municipal liability in City of Kenosha v. Bruno. ${ }^{18}$ Raising the issue sua sponte, Justice Rehnquist noted that Monroe itself had indicated that Supreme Court affirmances of equitable relief against municipalities should provide no inference that they were "persons" for 1983 purposes ${ }^{19}$ and, in one paragraph, ruled that "nothing in the legislative history ... or the language actually used by Congress . . . suggest[s] that the generic word 'person' ... . was intended to have a bifurcated application to municipal corporations depending on the nature of the relief sought . . . ." 20 Justice Douglas, who had authored the Court's interpretation of that legislative history in Monroe,${ }^{21}$ dissented, viewing Monroe as resting on a congressional fear that damage liability would paralyze local government. ${ }^{22}$

In another attempt to provide for municipal accountability, several courts held that if the municipality or government entity was subject to suit under state law, it should be so subject under section $1983 .{ }^{23}$ In doing so, the courts relied on 42 U.S.C. $\S$ I $988,{ }^{24}$ which provides for reference to state law where federal law is ineffective to carry out the purposes of the Civil Rights Acts. The lack of municipal liability, these courts suggested, rendered section 1983 largely ineffective. But in Moor v. County of Alamed $a,{ }^{25}$ the Supreme Court rejected this derivative use of section 1988. The Court found the provision not intended as an in-

supra note 13 . Indeed, the Court in Monroe specifically eschewed consideration of the policies underlying the 1983 action. See 365 U.S. at I 9 I.

${ }^{17}$ See, e.g., Schnell v. City of Chicago, 407 F.2d 1084 (7th Cir. 1969); Harkless v. Sweeny Indep. School Dist., 427 F.2d 319 (5th Cir. 1970), cert. denied, 400 U.S. 991 (197I) ; Dailey v. City of Lawton, 425 F.2d 1037 (roth Cir. 1970). This position drew support from Supreme Court decisions, before and after Monroe, sustaining award of equitable relief against governmental units. See Turner v. City of Memphis, 369 U.S. 350 ( 1962 ) (per curiam); Holmes v. City of Atlanta, 350 U.S. 879 (I 955 ) (per curiam).

${ }^{18} 4$ I 2 U.S. 507 (I973).

${ }^{19}$ Id. at 5 I3 (citing Monroe v. Pape, 365 U.S. I67, I9I \& n.50 (I96I)).

${ }^{20} 4 \mathrm{I} 2$ U.S. at $5 \mathrm{I} 3$.

21365 U.S. I67, 187-92 (1961).

${ }^{22} 4 \mathrm{I} 2$ U.S. at 516-I8 (Douglas, J., dissenting in part). See generally Kates \& Kouba, supra note II, at $147-50$.

${ }^{23}$ See, e.g., Carter v. Carlson, 447 F.2d 358 (D.C. Cir. 1970), rev'd on other grounds sub nom. District of Columbia v. Carter, 409 U.S. 4I8 (I973).

2442 U.S.C. \& 1988 (1970).

${ }^{25} 4$ II U.S. 693 (I972). 
dependent "Act of Congress providing for the protection of civil rights," 26 a prerequisite to jurisdiction under 28 U.S.C. $\S$ I 343 $(4) ;{ }^{27}$ rather, the section was designed to complement various other acts, such as section 1983 , which do create federal causes of action. ${ }^{28}$ Further, the Court held, section 1988 specifically provides for recourse to state law only where that law "is not inconsistent with the Constitution and laws of the United States." ${ }^{29}$ The effect of importing state law in this context, however, would be inconsistent with Monroe and its interpretation of the reach of section 1983 , for it would subject municipalities to liability. ${ }^{30}$

Monroe and City of Kenosha have had the effect of foreclosing, with few exceptions, an assertion of liability against entities resembling municipal corporations. Townships ${ }^{31}$ and counties, ${ }^{32}$ as well as cities, have been held exempt from liability. Further, most component municipal agencies have been excluded from section 1983 coverage, on the grounds that they are "but arms" of the municipality. ${ }^{33}$ Similarly, states and component state agencies have been sheltered by the Monroe immunity. Municipalities, it has been argued, are but political subdivisions of the state; if they are immune, so must be the states. ${ }^{34}$ And if the state agency is but an arm of the state, so that any potential liability will in fact be recovered from the state's fisc, that agency must also be immune. ${ }^{35}$ School districts and boards of education

${ }^{26}$ Id. at $702-06$.

${ }_{27} 28$ U.S.C. $\$ 1343(4)$ (1970) (granting jurisdiction to the federal district courts to hear any civil action "commenced by any person ... [ $t]$ o recover damages or to secure equitable or other relief under any Act of Congress providing for the protection of civil rights").

${ }^{28} 4$ I I U.S. at $703-06$.

${ }^{29} I d$. at 706 .

${ }^{30}$ Id. at 706-10.

${ }^{31}$ See, e.g., Pressman v. Chester Township, 307 F. Supp. I084 (E.D. Pa. 1969).

${ }^{32}$ See Moor v. County of Alameda, 4II U.S. 693, 706 (1973); Diamond v. Pitchess, 4 I I F.2d 565 (9th Cir. 1969).

33 See, e.g., Monell v. Department of Social Servs., 532 F.2d 259, 262-64 (2d Cir. 1976) (board of education), cert. granted, $97 \mathrm{~S} . \mathrm{Ct} .807$ (1977); United Farmworkers of Florida Housing Project, Inc. v. City of Delray Beach, 493 F.2d 799 (5th Cir. 1974) (county planning board); Garrett v. City of Hamtramck, 503 F.2d I236, I294 (6th Cir. 1974) (city planning commission).

${ }^{34}$ See, e.g., United States ex rel. Gittlemacker v. County of Philadelphia, 413 F.2d 84, 86 n.2 (3d Cir. 1969), cert. denied, 396 U.S. 1046 (I970); Cheramie v. Tucker, 493 F.2d 586 (5th Cir.), cert. denied, 4 I9 U.S. 868 (I974).

${ }^{35}$ See, e.g., Cheramie v. Tucker, 493 F.2d 586, 589 (5th Cir.) (department of highways), cert. denied, 4 I 9 U.S. 868 (1974); Sykes v. California, 497 F.2d I97, 201 (9th Cir. 1974) (department of motor vehicles); Curtis v. Everette, 489 F.2d 5 I6 (3d Cir. 1973) (bureau of corrections), cert. denied, 4I6 U.S. 995 (1974). Socalled "independent agencies" of state and local government have caused greater confusion. Compare Forman v. Community Servs., Inc., 500 F.2d I246, I255 (2d 
have caused the most confusion in this area, although the vast majority of cases hold them analogous to state agencies, political subdivisions or municipal corporations, and thus not subject to suit. $^{36}$

Quite apart from the Supreme Court's decisions in Monroe and City of Kenosha, the eleventh amendment ${ }^{37}$ has been interpreted to operate as an independent bar to suit for either damages or equitable relief directly against states and their component agencies ${ }^{38}$ - but not their political subdivisions ${ }^{39}$ - under section I 983 . Eleventh amendment jurisprudence has been marked by a consistent tension between the policies of sovereign immunity which the amendment reflects ${ }^{40}$ and the command of the federal

Cir. 1974), rev'd on other grounds sub nom. United Housing Foundation, Inc. v. Forman, 42 I U.S. 837 (1975), and Muzquiz v. City of San Antonio, 520 F.2d 993, 996-I001 (5th Cir. I975) (panel opinion) (agencies "persons" for § I983 purposes), with Muzquiz v. City of San Antonio, 528 F.2d 499 (5th Cir. 1976) (en banc) (adopting dissent to panel opinion), petition for cert. filed, 44 U.S.L.W. (U.S. May 27, 1976) (No. 75-1723), and Monell v. Department of Social Servs., 532 F.2d 259, 262-64 (2d Cir. 1976) (agencies not "persons" for § I983 purposes), cert. granted, $97 \mathrm{~S}$. Ct. 807 (1977). In general, the courts tend to look to such factors as whether the agency performs a governmental function, the degree to which it exercises powers and operates free from state or local control, its source of funding, its status under state or local law, and whether any ultimate judgment will be paid from the funds of the governmental entity.

${ }^{36}$ See, e.g., Monell v. Department of Social Servs., 532 F.2d 259, 262-64 (2d Cir. I976), cert. granted, 97 S. Ct. 807 (I977); Adkins v. Duval County School Bd., 5 I I F.2d 690, 69.2-93 (5th Cir. 1975); Singleton v. Vance County Bd. of Educ., 50I F.2d 429, 430 (4th Cir. 1974). But see Aurora Educ. Ass'n East v. Board of Educ. 490 F.2d 43I, 435 (7th Cir. I973), cert. denied, 4I6 U.S. 985 (1974); Scher v. Board of Educ., 424 F.2d 74I, 743-44 (3d Cir. 1970) (semble) ; Keckeisen v. Indiana School Dist., 509 F.2d 1062, I065 (8th Cir.), cert. denied, 423 U.S. 833 (1975). See also Note, Suing the School Board Under Section 1983, 2 I S.D.L. REv. 452 (1976). The determination of whether such entities are persons would properly seem to turn on the same factors considered with regard to "independent" state and local agencies. See note 35 supra. The Supreme Court has left the question open. See Mt. Healthy City School Dist. Bd. of Educ. v. Doyle, 97 S. Ct. 568, 57I-72 (I977).

37 The eleventh amendment provides:

The Judicial power of the United States shall not be construed to extend to any suit in law or equity, commenced or prosecuted against any one of the

United States by Citizens of another State, or by Citizens or Subjects of any

Foreign State.

38 The eleventh amendment has been read to apply where the entity sued is characterizable as the "alter ego" of the state so that any recovery will be paid from state funds. See Mt. Healthy City School Dist. Bd. of Educ. v. Doyle, $97 \mathrm{~S}$. Ct. 568, 572-73 (1977); Edelman v. Jordan, 415 U.S. 651, 662-64 (1974); Jagnandian v. Giles, 538 F.2d I 166 (5th Cir. 1976).

${ }^{39}$ See Edelman v. Jordan, 4I5 U.S. 65I, 667 n.I2 (1974); Lincoln County v. Luning, I33 U.S. 529 (I890).

${ }^{40}$ See generally Hans v. Louisiana, I34 U.S. I (I890); Tribe, Intergovernmental Immunities in Litigation, Taxation and Regulation: Separation of Powers Issues in Controversies About Federalism, 89 HARv. L. REv. 682, 683-88 (1976). 
system that the states conform their conduct to the mandates of the Constitution. ${ }^{41}$ In order to protect individual rights against unconstitutional state action, the Court has permitted aggrieved citizens to circumvent the eleventh amendment bar by permitting suits against state officials for equitable relief to restrain unconstitutional conduct, ${ }^{42}$ although such relief may often have a substantial, direct impact on the state treasury. ${ }^{43}$ However, relief which resembles a damage recovery by providing retroactive compensation for an aggrieved citizen from state funds may not be ordered. ${ }^{44}$ The citizen subject to a constitutional deprivation may proceed against the state official personally for damages under the section 1983 cause of action only so long as the judgment will not operate on its face to force a recovery directly from the state treasury. ${ }^{45}$

Even this eleventh amendment barrier to damage-like recoveries from the state treasury may apparently be overriden. The fourteenth amendment, which by its own terms imposes direct limits on the permissible scope of state action, ${ }^{46}$ sanctions "in-

${ }^{41}$ See U.S. Const. art. VI. See also Tribe, supra note 40, at 686-88; Note, Attorneys' Fees and the Eleventh Amendment, 88 HARv. L. Rev. 1875, 1878-82 (1975).

${ }^{42}$ See Ex parte Young, 209 U.S. I23 (1908) (state official acting unconstitutionally is stripped of official character and is subject to suit in equity); Home Tel. \& Tel. Co. v. City of Los Angeles, 227 U.S. 278 (1913) (unconstitutional action by state official removing eleventh amendment bar is nonetheless "state action" for fourteenth amendment purposes).

${ }^{43}$ See Edelman v. Jordan, 4I5 U.S. 65I, 667-69 (1974). See also Goldberg v. Kelly, 397 U.S 254 (1970).

${ }^{44}$ See Edelman v. Jordan, 415 U.S. 65I, 664-7I (1974); Jagnandian v. Giles, 538 F.2d II66, II76 (5th Cir. I976); Note, supra note 4I, at 1879-82.

${ }^{45} \mathrm{See}$ Scheuer v. Rhodes, $4 \mathrm{I} 6$ U.S. 232, 237-38 (1974). The eleventh amendment might well bar an action for damages against a state official in his representative capacity, since such a judgment would be paid from state funds, see Edelman v. Jordan, 4I5 U.S. 65I, 664-7I (1974), and could not be characterized as imposing "ird dual and personal" liability against such officials. See Scheuer v. Rhodes, $4 \mathrm{I} 6$ U.S. at 238 . While one court has suggested that damage awards against state officials might violate the eleventh amendment if the state has agreed to indemnify the officials, see Hallmark Clinic v. North Carolina Dep't of Human Resources, 380 F. Supp. II53, II59-60 \& n.I2 (E.D.N.C. I974) (three-judge court), aff'd per curiam on other grounds, $5 \mathrm{I}_{9} \mathrm{~F} .2 \mathrm{~d} \mathrm{I}_{3} \mathrm{I}_{5}$ (4th Cir. 1975), such a voluntary assumption of responsibility should not be sufficient to create eleventh amendment immunity, since it would enable the state to shield all of its officials from the $\S 1983$ damage action through an indemnification agreement. Such action might well be construed as a voluntary waiver of eleventh amendment immunity. See Tribe, supra note 40 , at 687 n.25; cf. Gates v. Collier, 48.9 F.2d 298 (5th Cir. 1973) (award of equitable monetary relief upheld despite indemnification agreement), vacated and remanded en banc on other grounds, 522 F.2d 8I (5th Cir. 1975); Harkless v. Sweeny Indep. School Dist., 427 F.2d 319 (5th Cir. 1970) (same), cert. denied, 400 U.S. 991 (197 I).

${ }^{46}$ See Fitzpatrick v. Bitzer, 427 U.S. 445, 453-55 (1976); pp. I144-46, I181-82, supra. 
trusions by Congress . . . into the judicial, executive, and legislative spheres of autonomy previously reserved to the States" 47 by granting Congress the power to enforce its commands "by appropriate legislation." ${ }^{48}$ Under this power, Congress may provide for private suits against states or state officials which would otherwise be impermissible under the eleventh amendment. $^{49}$

2. Personal Immunities. - The immunities afforded governmental entities by Monroe and City of Kenosha ${ }^{50}$ and by the eleventh amendment ${ }^{51}$ require individuals who seek damages or equitable relief under section 1983 to style their claims as suits against individual state officers. Monroe and City of Kenosha, however, may also afford a measure of immunity to individual defendants. It is generally recognized that Monroe bars damage actions against officials in their representative capacity since such suits are, in essence, actions for damages against the governmental unit. ${ }^{52}$

The broadest reading of City of Kenosha would afford government officials a total immunity from 1983 suits for injunctive relief, since even naked prohibitory injunctions, and surely wideranging affirmative injunctive decrees, have the effect of imposing costs on the governmental unit and are, in that sense, directed against that unit. ${ }^{53}$ But such a reading would not only afford governmental units significantly greater immunity than they enjoy

${ }^{47}$ Fitzpatrick v. Bitzer, 427 U.S. 445, 455 (1976).

${ }^{48}$ U.S. Const. amend. XIV, § 5 .

${ }^{49}$ See Fitzpatrick v. Bitzer, 427 U.S. 445,45 I-56 (1976). Fitzpatrick provides clear authority for the proposition that Congress may overrule the governmentalexclusion-from-liability holding of Monroe v. Pape, 365 U.S. I67, I87-91 (I96I), a question left open in Moor v. County of Alameda, 4I I U.S. 693, 709 (I973). See S. 35, 95th Cong. Ist Sess, I 23 Cong. Rec. S20I-05 (daily ed. Jan. Io, I977) (proposed Civil Rights Improvement Act of 1977 would establish a species of governmental liability under $\$ 1983$ ); pp. 1360-6r infra.

${ }^{50}$ See pp. II93, II $94-95$ supra.

${ }^{51}$ See pp. I1 $95-96$ supra.

52 See, e.g., Monell v. Department of Social Servs., 532 F.2d 259, 264-67 (2d Cir. 1976), cert. granted, 97 S. Ct. 807 (1977); Hayes v. Cape Henelopen School Dist., 34I F. Supp. 823, 829 (D. Del. 1972); Bennett v. Gravelle 323 F. Supp. 203, 2 I I (D. Md.), aff'd on other grounds, 45 I F.2d Ior I (4th Cir. I97I), cert. denied, 407 U.S. 917 (1972); Westberry v. Fisher, 309 F. Supp. I2, 18 (D. Me. 1970). See also Scheuer v. Rhodes, 416 U.S. 232, 237-38 (1974). As in the eleventh amendment context, the fact that a governmental entity not a "person" for $\$ 1983$ purposes elects to indemnify its officials should not bar damage recoveries. See note 45 supra.

${ }^{53}$ See Edelman v. Jordan, 415 U.S. 651, 667-68 (1974); The Supreme Court, 1972 Term, 87 HARv. L. Rev. 55, 252, 258-60 (1973). Injunctions imposing affirmative obligations on state and local government officials to correct systemic deprivations may impose considerable costs on governmental units, but have been permitted nonetheless. See pp. 1227-50 infra. 
under the eleventh amendment, ${ }^{54}$ it would also run counter to the express language of section 1983 , which specifically authorizes equitable actions against government officers.

Some courts, drawing an analogy to the eleventh amendment jurisprudence of Edelman v. Jordan ${ }^{55}$ have viewed Monroe and City of Kenosha as implicitly barring suits for equitable relief, nominally brought against government officials, in which the relief will have the effect of imposing retroactive damage-like recoveries payable from government funds. They have, however, allowed relief which imposes costs ancillary to prospective compliance with the mandates of the Constitution..$^{58}$

While such an analogy is facially appealing, it is inappropriate; in Edelman, the basis for the Court's limitation on permissible equitable relief was not a general application of the "partyin-fact" doctrine, but rather the constitutional command of the eleventh amendment, which Justice Rehnquist indicated provides strong protections for states, but not for lesser governmental entities. ${ }^{57}$ When the official sued in the section 1983 action is not a state official - and thus where no eleventh amendment concerns are implicated - the question of the permissible scope of relief is a matter of statutory interpretation, not requiring a construction as strict as that command by the Constitution. The reading of City of Kenosha most consistent with the purpose and language of section 1983 would not be to impose artificial limits

${ }^{54}$ See pp. I I $95-96$ supra.

${ }^{55} 4 \mathrm{I} 5$ U.S. $65 \mathrm{I}, 667-68$ (1974).

${ }^{56}$ See, e.g., Muzquiz v. City of San Antonio, 528 F.2d 499, 500-01 (5th Cir. 1976) (en banc) (adopting dissent to panel opinion), petition for cert. filed, 44 U.S.L.W. 3703 (U.S. May 27, 1976) (No. 75-1723); Singleton v. Vance County Bd. of Educ., 501 F.2d 429 (4th Cir. 1974) (per curiam); Campbell v. Gadsden County School Bd., 534 F.2d 650, 655 n.ro (5th Cir. 1976) (dictum) (while $\S$ I983 action against officials in representative capacity will support award of equitable reinstatement, it will not support award of back pay) ; $c f$. McGill v. Parsons, 532 F.2d 484, 485 n.I (5th Cir. 1976) (distinguishing Muzquiz and permitting prospective injunctive relief). Indeed, $M u z q u i z$ is unique in that it appears to adopt the broadest possible reading of City of Kenosha - that local government officials are not amenable to suit under $\S 1983$ for any kind of declaratory or injunctive relief whatsoever. Plaintiffs had challenged the constitutionality of a state statute prohibiting refunds of money deducted from their pay and placed in a pension fund. In addition to prohibiting relief which would have ordered a refund to the plaintiffs of past contributions to the pension fund, the court of appeals reasoned that either declaratory or prospective injunctive relief was barred, because "a declaration that [the statute] is unconstitutional, or an injunction against its enforcement, is in substance a determination of plaintiffs' entitlement to restitution." 528 F.2d at 501. But see Thurston v. Dekle, 53 I F.2d 1264, I269 (5th Cir. 1976) (Muzquiz interpreted as general bar only to Edelman-like restitutionary and damage recoveries). See also 55 TEx. L. REv. 501, 504, 505-09 (1977).

${ }^{57}$ See Edelman v. Jordan, 4I5 U.S. 65I, 667-68 \& n.I 2 (I974) 
on equitable relief simply because some of its forms more obviously affect the local governmental unit than others ${ }^{58}$ indeed, to engage in such analysis would appear to ignore City of Kenosha's strong condemnation of efforts to define the scope of section I 983 according to the nature of the relief sought. ${ }^{59}$

Even when suits are directed at officials in their individual capacities, immunity may be extended. It is well established that state judges, legislators, and prosecutors enjoy an absolute immunity from section 1983 liability for damages. In Tenney $v$. Brandhove, ${ }^{60}$ addressing the question of legislative immunity from section 1983 damage actions, the Court held that immunity was so firmly established at common law that Congress would have specifically provided for its abolition under section 1983 had it so intended. ${ }^{61}$ Lower courts quickly applied this rationale to create a judicial immunity in section 1983 actions, ${ }^{62}$ and sixteen years later, in Pierson v. Ray ${ }^{63}$ the Supreme Court approved this extension. The trio of absolute immunities was completed by the Court last Term in Imbler v. Pachtman ${ }^{64}$ which established an absolute immunity for prosecutors. Building on these decisions, some lower courts have extended absolute immunities to justices of the peace, ${ }^{65}$ municipal referees, ${ }^{66}$ parole board members, ${ }^{67}$ and judicial clerks, ${ }^{68}$ as well as to those acting pursuant to presumptively valid court orders. ${ }^{69}$

${ }^{58}$ See The Supreme Court, 1972 Term, supra note 53, at 259-60; accord, Burt v. Board of Trustees of Edgefield City School Bd., 52I F.2d I20I (4th Cir. 1975); Thomas v. Wood, 529 F.2d 916 (4th Cir. 1975) (permitting award of back pay under $\S \mathrm{I} 983$ against officials in representative capacity); Harkless v. Sweeny Indep. School Dist., 427 F.2d 319 (5th Cir. 1970) (award of back pay is integral part of remedy of equitable reinstatement), cert. denied, 400 U.S. 99I (I97 I). See also 55 Tex. L. Rev. 501, 505-09; Muzquiz v. City of San Antonio, 523 F.2d 499, 50I-03 (5th Cir. I976) (en banc) (Tuttle, J., dissenting), petition for cert. filed, 44 U.S.L.W. 3703 (U S. May 27, I976) (No. 75-1723).

${ }^{59} 4 \mathrm{I} 2$ U.S. 507, 513 (1973); see The Supreme Court, I972 Term, supra note 53 , at 260 .

${ }^{60} 34$ I U.S. 367 (I95I).

${ }^{61}$ Id . at 376 .

${ }^{62}$ See, e.g., Bauers v. Heisl, 36I F.2d 58I (3d Cir. 1965) (en banc).

${ }^{63} 386$ U.S. 547 (1967).

${ }^{64} 424$ U.S. 409 (1976).

${ }^{65}$ See Pennebaker v. Chamber, 437 F.2d 66 (3d Cir. 1971).

${ }^{66}$ See Lucarell v. McNair, 453 F.2d 836 (6th Cir. 1972) (dictum).

${ }^{67}$ See Allison v. California Adult Auth., 4I9 F.2d 822 (9th Cir. 1969).

${ }^{68}$ See Denman v. Leedy, 479 F.2d 1097 (6th Cir. 1973) (clerk with discretionary duty of fixing bail in misdemeanor cases immune); Smith v. Rosenbaum, 460 F.2d rorg (3d Cir. 1972) (clerk with ministerial duty part of the judicial process and hence immune). Many courts refuse to extend absolute immunity to purely ministerial acts performed by judicial clerks. See, e.g., Barnes v. Dorsey, 480 F.2d 1057 (8th Cir. 1973); McCray v. Maryland, 456 F.2d I (4th Cir. I972).

${ }^{69}$ See, e.g., Mississippi ex rel. Giles v. Thomas, 464 F.2d 156 (5th Cir. 1972); 
Though nominally absolute, these immunities are not without exceptions. To be completely protected, the defendant's challenged conduct must have occurred in the performance of his official functions. But the exceptions do not undermine the immunities in any significant way, with the result that individuals suffering a constitutional violation at the hands of legislators, judges, and prosecutors are generally foreclosed from any recovery, no matter how malicious the underlying conduct. While this result may be justifiable in the context of suits against legislators, it is clearly unwarranted as applied to judges and prosecutors. The legislative immunity, conceived amid the constitutional struggle in seventeenth-century England and enshrined in the speech and debate clause of the Constitution, ${ }^{70}$ enjoys a unique historical position. Its constitutional basis and the consistency with which it has been maintained at common law bespeak a concern for protecting the heart of the democratic process from judicial scrutiny that ought not to be lightly overruled. Moreover, the practical obstacles to permitting suits against legislators are immense: even to decide who would be an appropriate party defendant when a legislature enacted a constitutionally offensive statute would pose a massive problem. Only in the area of legislative investigations might this rule be relaxed; ${ }^{71}$ even then, the difficulty of separating the investigative from the deliberative function might well be conclusive against damage liability.

No similarly compelling justifications exist for granting judges and prosecutors absolute immunity. Even beyond the language of section 1983 , which facially creates a liability admitting of no exceptions, there is evidence of a congressional intent to hold at least judges liable. The model for section 1983 was 18

Burkes v. Callion, 433 F.2d 318 (gth Cir. 1970) (court-appointed psychiatrists); Robichaud v. Ronan, 35I F.2d 533 (9th Cir. 1955); Note, The Doctrine of Official Immunity Under the Civil Rights Acts, 68 HARv. L. REv. I229, I230, I232 (I955) [hereinafter cited as Doctrine of Official Immunity]; cf. O'Connor v. Donaldson, 422 U.S. 563,577 (1975) (state psychiatrist not acting pursuant to court order entitled to only qualified immunity). The justification for absolute immunity here is twofold: ( $\mathrm{I}$ ) it would disrupt the judicial process to have those responsible for carrying out its directives entertain doubts as to the propriety of so acting; and (2) it is unjust to subject those who act pursuant to judicial orders to liability while shielding those who issue the orders.

${ }^{70}$ U.S. Const. art. I, § 6; see Scheuer v. Rhodes, 4 I6 U.S. 232, 239 n.4 (1974); Tenney v. Brandhove, 34I U.S. 367, 372-75 (I95I).

${ }^{71}$ Conceivably, a legislator should not be shielded by absolute immunity where he uses the investigatory authority for his own improper motives, rather than as an adjunct to the process of enactment of legislation. But cf. Tenney v. Brandhove, 34I U.S. 367, 377 (195I) (claim of improper motive does not abrogate legislative immunity). 
U.S.C. $\S 242,{ }^{72}$ providing criminal liability for civil rights violations, under which judges ${ }^{73}$ legislators ${ }^{74}$ and prosecutors ${ }^{75}$ enjoy no immunity. In addition, debate on section 1983 itself indicated no great respect for members of state judiciaries; county judges were characterized as "despots" who acted "without regard to law or justice," ${ }^{76}$ and the specific statements of several Congressmen that section 1983 would cover judicial acts were never contradicted. ${ }^{77}$ Moreover, judicial immunity at common law was not as "solidly established" in I87 I as the Supreme Court concluded in Pierson. ${ }^{78}$ The states were sharply divided on the issue, ${ }^{79}$ and even the Supreme Court had left open the question whether malicious or corrupt judicial acts "in excess of jurisdiction" might be outside the shield. ${ }^{80}$ Thus, in light of the

${ }^{72}$ See Cong. Globe, $42 \mathrm{~d}$ Cong., Ist Sess. app., at 68 (1871) (Rep. Shellabarger).

See also Monroe v. Pape, 365 U.S. 167, 184-85 (1961).

I8 U.S.C. $\$ 242$ (1970) provides:

Whoever, under color of any law . . . willfully subjects any inhabitant of any State ... to the deprivation of any rights, privileges, or immunities secured or protected by the Constitution or laws of the United States . . . on account of such inhabitant being an alien, or by reason of his color, or race, ... shall be fined not more than $\$ 1,000$ or imprisoned not more than one year, or both; and if death results shall be subject to imprisonment for any term of years or for life.

${ }^{73}$ The legislative history of $\S 242$ indicates an intention to hold judges liable. See Cong. GLobe, 39th Cong., Ist Sess. 475-76, II $154-55,1680,1758,1778,1837$ (1865-1866); Kates, Immunity of State Judges Under the Federal Civil Rights Acts: Pierson v. Ray Reconsidered, 65 Nw. L. Rev. 615, 62I-23 (197I) [hereinafter cited as Immunity of State Judges]. Recent Supreme Court decisions have assumed, without deciding, that judges are not immune from $\S 242$ liability. See Imbler v. Pachtman, 424 U.S. 409, 429 (1976); O'Shea v. Littleton, 4 I4 U.S. 488, 503 (1973).

${ }^{74}$ Dicta in recent Supreme Court cases indicate that legislators may be held criminally liable under $\S 242$. See O'Shea v. Littleton, 4I4 U.S. 488, 503 (I973) (citing Gravel v. United States, 408 U.S. 606, 627 (1972) (the judicially fashioned doctrine of immunity does not reach "so far as to immunize criminal conduct proscribed by an Act of Congress")).

${ }^{75}$ See Imbler v. Pachtman, 424 U.S. 409, 429 (1976) (dictum). See also CaL. Penal Code $\$ 2$ I 7 (criminal liability for prosecutors).

${ }^{76}$ Cong. Globe, $42 \mathrm{~d}$ Cong., ist Sess. 186, 277, 394, 505, 654 (1871); see Immunity of State Judges, supra note 73 , at $62 \mathrm{I}-23$; Note, Liability of Judicial Officers Under Section 1983, 79 YALE L.J. 322, 328 (I969) [hereinafter cited as Liability of Judicial Officers].

${ }^{77}$ See Cong. Globe, $42 \mathrm{~d}$ Cong., Ist Sess. 394 (1871) (Rep. Rainer); id. at 315, 429, 505, 654; id. app., at 186 (Rep. Platt); id. app., at 153, 277, 179. Specific statements of judicial liability were issued by Senator Thurman, id. app., at 2 I 7 , Rep. Lewis, id. at 385, and Rep. Arthur, id. at 365-66. See also Liability of Judicial Officers, supra note 76 , at $328 \& \mathrm{nn} .37-39$.

${ }^{78} 386$ U.S. $547,553-54$ (1967).

${ }^{79}$ See Liability of Judicial Officers, supra note 76, at 326-27 \& nn.29-32.

${ }^{80}$ Randall v. Brigham, 74 U.S. ( 7 Wall.) 523,536 ( 1868 ), the leading Supreme Court case on judicial immunity, contained dictum to the effect that judicial acts "in excess of jurisdiction," if done maliciously or corruptly, would not be immune 
murky picture presented by both federal and state law, a Congress intending to subject judges to liability might well not have felt compelled to state that explicitly.

Exempting classes of potential defendants from the operation of section 1983 has been justified on several grounds apart from legislative history and the "background of tort law." Chief among these has been the fear that vexatious litigation will cause discretionary decisionmakers to set avoidance of liability above independence and integrity as goals in choosing among alternative courses of action. But this rationale would logically support an absolute immunity for all governmental decisionmakers vested with discretion - a result which would wholly and impermissibly undermine the section 1983 damage action. As a result, if absolute immunities for judges and prosecutors are to be justified, there must be some ground that sets these officials apart from other governmental decisionmakers.

Not until Imbler v. Pachtman did the Court set forth the factors that putatively differentiate the judicial from other governmental processes. ${ }^{81}$ Of greatest weight ${ }^{82}$ was the importance of

from liability. Bradley v. Fisher, 80 U.S. ( 13 Wall.) 335 ( 1872 ), had yet to be decided.

81424 U.S. 409 (1976). Among the factors listed by the Court are a number that do not appear to apply peculiarly to the judicial process, or that do not withstand close analysis. First, the opinion articulates the "intimidation" analysis, by which the court suggested that prosecutors (and presumably judges) would be subject, absent absolute immunity, to the burden of many vexatious suits. Id. at $4^{24-25}$. While the judicial process, focusing as it does on individuals, may prove a more fertile spawning ground for 1983 plaintiffs than the legislative process, other state governmental processes, such as the routine conduct of police business, impinge as directly on as many individuals, and officers involved in these processes enjoy only a qualified immunity, see pp. 1209-I 7 infra.

The Court further reasoned that permitting $\S 1983$ actions questioning discretion relative to the judicial process would "require a virtual retrial of the criminal offense in a new forum, and the resolution of some technical issues by the lay jury." 424 U.S. at 425 . In part, these concerns are not unique to $\$ 1983$ actions based on judicial or prosecutorial decisions: actions against state executive officials often require detailed inquiry into their decisionmaking processes, see Scheuer v. Rhodes, 416 U.S. 232, 246-48 (1974), and will often involve the jury in the determination of complex questions of law and fact. Suits against judges and prosecutors, however, may raise difficulties not found in actions against other officials since principles of collateral estoppel may bar relitigation, and a successful $\S$ I 983 damage action may undermine the validity of a criminal conviction. See pp. ${ }^{1350-51}$ infra.

${ }^{82} \mathrm{~A}$ second part of the Court's argument concerning the uniqueness of the judicial process was based on the existence of post trial procedures to correct alleged constitutional deprivations occurring at trial. See Imbler v. Pachtman, 424 U.S. 409, 427 (1976). Absent absolute immunity, the focus of such corrective mechanisms might "be blurred by even the subconscious knowledge that a posttrial decision in favor of the accused might result in the prosecutor [or judge] 
permitting the factfinder to have access to all relevant evidence. This rationale, however, does not support absolute immunity for judicial and quasi-judicial officers under all circumstances. For example, the factfinding process does not generally involve consideration of questions of law; thus, a concern for the integrity of the process affords no justification for shielding a judge who knowingly falsifies the law. Indeed, preserving access to all relevant evidence militates against an immunity for a prosecutor who knowingly withholds such information. ${ }^{83}$ Nor, finally, does this argument point to an immunity for prosecutors exercising

being called upon to respond in damages for his error or mistaken judgment." Id. But as Justice White persuasively responds, such reasoning would apply equally to policemen, who enjoy only a qualified immunity. See id. at 436 n.3 (opinion concurring in the judgment).

Furthermore, the Court suggested that the $\S 1983$ action was not necessary to correct any abuses that might occur in the judicial process, since alternative remedial mechanisms are available: judges and prosecutors could be punished criminally under 18 U.S.C. $\$ 242$ (1970); the prosecutor (and presumably judge) is susceptible to professional discipline; and errors may be corrected on appeal. 424 U.S. at $428-29$.

While $\S 242$ applies to judges and prosecutors, see p. I20I supra, its operation as a deterrent to unconstitutional behavior is highly dubious, since the government itself must initiate prosecution, and there are no modern cases reported of judges or prosecutors acutally being subject to its liability. The possibility of professional discipline is also slim: the American Bar Association is not known for its efforts at self-policing. See generally Morgan, The Evolving Concept of Professional Responsibility, 90 Harv. L. REv. 702 (1977). While judicial and prosecutorial errors may be corrected on appeal, such correction may offer little in the way of compensation to a genuinely wronged $\S 1983$ plaintiff, particularly one who has been confined pending review, see, e.g., Hilliard v. Williams, 465 F.2d I2 I2 (6th Cir. 1972), decision on remand rev'd, 5 I6 F.2d I344 (6th Cir. 1975), vacated and remanded, 424 U.S. 961 (1976) (for consideration in light of Imbler v. Pachtman), remanded with directions to dismiss, 540 F.2d 220 (6th Cir. 1976), or who has suffered serious stigmatization as a result of subjection to the judicial process. In addition, whether or not the appeal technically vindicates the injured party, the inconvenience and expense of litigation remains. See generally Douglas v. California, 372 U.S. 353 (1963); Griffin v. Illinois, 35 I U.S. I2 (1956). The appeal remedy may also not even be available to citizens wronged by actions of prosecutors and quasi-judicial officials, and the Supreme Court has recognized that citizens' constitutional rights may be seriously violated although a conviction, predicate to appellate review in a criminal case, is never obtained. See Dombrowski v. Pfister, 380 U.S. 479 ( 1965 ). Indeed, one of the evils specifically referred to in the $\S 1983$ congressional debates, see Cong. Globe, $42 \mathrm{~d}$ Cong., Ist Sess. app., I85 ( 1871 ), was harassing litigation, which although certain to lose, could put the citizen to considerable expense and annoyance.

${ }^{83}$ See Imbler v. Pachtman, 424 U.S. 409, 442-45 (1976) (White, J., concurring in the judgment). See also S. 35, 95th Cong., ist Sess., \& 2 (d) (1976) (proposed legislation amending $\S 1983$ to abolish prosecutorial immunity for withholding evidence); I23 Cong. Rec. S203 (daily ed. Jan. 10, 1977) (remarks of Sen. Mathias). 
their investigative functions. ${ }^{84}$ Although one might well be concerned with suits which cast doubt on the integrity of those charged with enforcement of the law, respect for the legal system in the long run may be hampered rather than enhanced by a scheme which seems to place at least some individuals beyond the reach of the Constitution.

The only persuasive reason for protecting the occasional dishonest or malicious decisionmaker is, of course, that it is necessary to protect the majority of honest ones, and to protect the process. ${ }^{85}$ But the absolute immunities established by the Court in its zeal to safeguard the honest official and the process he embodies are clearly overbroad. While no form of negligence liability may be appropriate for judges and prosecutors - since such liability could well chill the independence and integrity of the adjudicative process - it must be recognized that judges and prosecutors are in a position to engage in conduct so reprehensible and so potentially harmful to both the parties before them and to the judicial process that a chilling effect on that conduct is precisely what is desirable. ${ }^{86}$ A scheme of qualified immunities, analogous to those afforded most executive officers, ${ }^{87}$ would adequately preserve the integrity of the processes involved while at the same time protecting the constitutional rights secured to individuals through section $1983 .{ }^{88}$

\section{B. State of Mind Requirements}

Monroe v. Pape held that a section 1983 plaintiff need not prove that the defendant acted with a specific intent to deprive

${ }^{84}$ See 424 U.S. at 43 I \& n.33.

${ }^{85}$ See Gregoire v. Biddle, I77 F.2d 579, 58I (2d Cir. 1949) (L. Hand, J.). See also Imbler v. Pachtman, 424 U.S. 409, 426 (1976); id. at 436-37 (White, J., concurring in the judgment).

${ }^{86}$ See Imbler v. Pachtman, 424 U.S. 409, 444-45 (I976) (White, J., concurring in the judgment); Hilliard v. Williams, 465 F.2d I 2 I 2 (6th Cir. 1972), decision on remand rev'd, $5 \mathrm{I} 6$ F.2d $\mathrm{I} 344$ (6th Cir. I975), vacated and remanded, 424 U.S. 96I (1976) (for consideration in light of Imbler $v$. Pachtman), remanded with directions to dismiss, 540 F.2d 220 (6th Cir. 1976); Haaf v. Grams, 355 F. Supp. 542 (D. Minn. I973); Liability of Judicial Officers, supra note 76, at 33 I-32.

${ }^{87}$ See pp. I 209-I 7 infra.

${ }^{88}$ Should there be fear that the qualified immunity standard as applied to judges and prosecutors might, because of ambiguity in instructions to the jury, not adequately reflect the nature of their positions and the need to protect the integrity and operation of the judicial process, although Scheuer v. Rhodes, 4I6 U.S. 232, 238-49 (1974), see pp. I2II-I 7 infra, would certainly contemplate an immunity considerate of such factors, liability for judges and prosecutors could be limited to those cases in which either actual malice or violation of clearly established constitutional rights could be demonstrated. See Liability of Judicial Officers, supra note 76, at 334-35; Immunity of State Judges, supra note 73, at 623-27. 
the plaintiff of his constitutional rights in order to establish a cause of action under the statute. ${ }^{89}$ Indeed, the broad language of the Civil Rights Act - which provides for liability for any person "causing" a constitutional deprivation ${ }^{90}$ - when read in the context of Monroe's open-ended declaration that section I 983 liability is to be determined by reference to "the background of tort liability that makes a man responsible for the natural consequences of his actions," ${ }^{91}$ and of Monroe's characterization of section 1983 as providing a federal cause of action "because, by reason of prejudice, passion, neglect, intolerance or otherwise, state laws might not be enforced," 92 could be seen to establish a right to relief based solely on the fact of tortious injury to the citizen, so long as the fact of that injury constituted a constitutional deprivation. The courts, however, have developed doctrines relating primarily to the state of mind of the defendant which, although not uniformly applied, have effectively reduced the scope of section r 983 . First, in some cases, courts have defined the category of actions giving rise to a section 1983 claim so as to exclude at least instances of isolated negligent misconduct from the reach of the statute. ${ }^{93}$ Second, even where the defendant has acted intentionally so as to deprive the plaintiff of a constitutional right, the courts have nonetheless barred the recovery of damages when the defendant is able to establish that he acted in good faith. ${ }^{94}$

I. Negligence Liability. - The lower courts have generally agreed that isolated acts of negligence by state officials do not give rise to a constitutional violation..$^{95}$ This view was apparently endorsed by the Supreme Court this Term, at least in the context of actions claiming denial of rights secured by the eighth amendment. In Estelle v. Gamble, ${ }^{96}$ the Court held that "[i]n order to state a cognizable claim, a prisoner must allege acts or omissions sufficiently harmful to evidence deliberate indifference to serious medical needs. It is only such indifference that can offend 'evolving

${ }^{89}{ }_{365}$ U.S. I67, I87 (196.1); see pp. I169-7 I supra.

${ }^{90}$ The language of $\S 1983$ has been interpreted to create liability for inaction. See The Supreme Court, 1975 Term, 90 HARv. L. REv. 56, 242 \& n.25 (I976).

91365 U.S. at 187 .

${ }^{92}$ Id. at 180 .

${ }^{93}$ See, e.g., Walton v. Salter, 536 F.2d 1023 (5th Cir. 1976); Williams v. Vincent, 508 F.2d 54I (2d Cir. 1974); Johnson v. Glick, 48I F.2d 1028, 1033 (2d Cir. 1973); United States ex rel. Miller v. Twomey, 479 F.2d 701 (9th Cir. I973); Puckett v. Cox, 456 F.2d 233 (6th Cir. 1972); Martinez v. Mancusi, 443 F.2d 921 (2d Cir. 1970).

${ }^{94}$ See pp. 1 209-17 infra.

${ }^{95} \mathrm{See}$ cases cited note 93 supra.

${ }^{96} 97$ S. Ct. 285 ( 1976 ). 
standards of decency' in violation of the Eighth Amendment." 97 When it applied this standard to the prisoner's claim that the prison medical director's failure to perform an X-ray or to use additional diagnostic techniques constituted cruel and unusual punishment ${ }^{98}$ the Court found no constitutional deprivation, reasoning that "[a]t most, it [the doctor's failure] is medical malpractice, and as such the proper forum is state court under the Texas Tort Claims Act." 99

The standard of "deliberate indifference" enunciated by the Court for determining eighth amendment violations is consistent with the judgment of many lower courts that actions of state officials must be characterizable as "wanton," "reckless," or "grossly negligent" in order to state a claim under section $1983,{ }^{100}$ particularly where an isolated incident of abuse occurred. But the standard does not appear to bar establishment of section 1983 liability where a series of negligent acts or a pattern of negligent conduct is established, for such a pattern may properly lead to a finding that the official responsible evinced "deliberate indifference" or, in fact, had acted wantonly or with gross negligence. ${ }^{101}$

For many section 1983 plaintiffs, the ability to establish a claim against the lower level state official alleged to have committed the abuse in question is less significant than securing a determination of the liability of the officer's supervisor. In many cases where constitutional deprivations have been clearly established liability on the part of a supervisory official may be necessary if the plaintiff is to have any hope of a damage recovery. Supervisors may be better able to bear the costs of a damage judgment. Moreover, in some cases the plaintiff may not be able to identify the lower level officials who actually inflicted the injury. ${ }^{102}$ Further, assessment of damages against a supervisory official may offer a more meaningful possibility of deterring future unconstitu-

${ }^{97}$ Id. at 292 (emphasis added). In dissent, Justice Stevens criticized the Court for "improperly attach [ing] to the subjective motivation of the defendant as a criterion for determining whether cruel and unusual punishment has been inflicted. Subjective motivation may well determine what, if any, remedy is appropriate against a particular defendant. However, whether the constitutional standard has been violated should turn on the character of the punishment rather than the motivation of the individual who inflicted it." Id. at 297 (dissenting opinion).

${ }^{88}$ Id. at $292-93$.

${ }^{99}$ Id. at 293. See also Johnson v. Glick, 48 I F.2d 1028, 1033 (2d Cir.), cert. denied, 4 I4 U.S. 1033 (1973).

${ }^{100}$ See, e.g., Russ v. Ratliff, 538 F.2d 799 (8th Cir. 1976), cert. denied, 97 S. Ct. 740 (1977); Parker v. McKeithen, 488 F.2d 553 (5th Cir.), cert. denied, 419 U.S. 838 (1974); Jenkins v. Averett, 424 F.2d 1228 (4th Cir. 1970).

${ }^{101}$ See Estelle v. Gamble, 97 S. Ct. 285, 291 (1976) ("Regardless of how evidenced, deliberate indifference to a prisoner's serious illness or injury states a cause of action under $\S 1983 . ")$.

${ }^{102}$ See, e.g., Byrd v. Brishke, 466 F.2d 6, II (7th Cir. 1972). 
tional conduct by lower officials, since the supervisor will be in a better position to institute corrective measures in the government operations he controls.

Although the decisions have not been uniform, plaintiffs who bring damage actions against supervisory officials, attempting to establish their liability for the acts of their subordinates, have generally encountered greater difficulty than in suits against subordinate officers. The doctrine of respondeat superior has been held generally inapplicable to the section 1983 action; ${ }^{103}$ and most courts have been unsympathetic to the claim that higher level officers have a general duty to the public to supervise, correct, and control the actions of their subordinates. ${ }^{104}$ Plaintiffs have thus been required to demonstrate that the supervisory defendant actually participated in, encouraged, or directed the illegal conduct of lower level officials. ${ }^{105}$ In effect, this has limited the instances where plaintiffs can recover primarily to situations where there has been a history of widespread abuse in the conduct of the governmental operation under the defendant supervisor's control. Where plaintiffs have been able to demonstrate a pattern or practice of improper behavior, knowledge of it has been imputed to the responsible supervisory official so that the injury to the individual no longer appears to be the result of purely negligent conduct - for which the supervisor would not normally be liable - but of the "deliberate indifference" of the supervisor who might have, but did not, take action to prevent continued injuries. ${ }^{106}$

${ }^{103}$ See, e.g., Navarette v. Enomoto, 536 F.2d 277, 282 (9th Cir. 1976), cert. granted, 97 S. Ct. 783 (1977); Jennings v. Davis, 476 F.2d 127I, I274-75 (8th Cir. 1973); Johnson v. Glick, 48I F.2d 1028, 1034 (2d Cir.), cert. denied, 414 U.S. ro33 (1973). But see Carter v. Carlson, 447 F.2d 358 (D.C. Cir. I97I), rev'd on other grounds sub nom. District of Columbia v. Carter, 409 U.S. 4 I 8 (1973) ; Hesselgesser v. Reilly, 440 F.2d 901 (9th Cir. 1971) (respondeat superior applicable in $\S 1983$ action if provided for by state law); Lewis v. Brautigam, 227 F.2d 124 (5th Cir. 1955) (same).

${ }^{104}$ See, e.g., Ford v. Byrd, 544 F.2d I94 (5th Cir. 1976); Parker v. McKeithen, 488 F.2d 553 (5th Cir. 1974), cert. denied, 4I9 U.S. 838 (1974); Johnson v. Glick, 48I F.2d 1028, 1034 (2d Cir.), cert. denied, 414 U.S. ro33 (I973); Delaney v. Dias, 4I5 F. Supp. 135I (D. Mass. 1976); Ammlung v. City of Chester, 355 F. Supp. 1300 (E.D. Pa. 1973), aff'd, 494 F.2d 8I I (3d Cir. 1974). But see Sims v. Adams, 537 F.2d 829, 832 (5th Cir. 1976) (supervisory liability available for personal participation, breach of state law duty; notice of past culpable conduct and failure to prevent recurrence); Carter v. Carlson, 447 F.2d 358 (D.C. Cir. I97I) (supervisors liable for negligent failure to train subordinates), rev'd on other grounds sub nom. District of Columbia v. Carter, 409 U.S. 4 I8 (I973).

${ }^{105}$ See, e.g., Ford v. Byrd, 544 F.2d 194 (5th Cir. 1976); Jennings v. Davis, 476 F.2d I27I (8th Cir. I973); Via v. Cliff, 470 F.2d 27I (3d Cir. 1972); Adams v. Pate, 445 F.2d 105 (7th Cir. 197I); Martinez v. Mancusi, 443 F.2d 92I (2d Cir. 1970), cert. denied, $40 \mathrm{I}$ U.S. 983 (197I).

${ }^{100}$ See, e.g., Sims v. Adams, 537 F.2d 829 (5th Cir. 1976) (dictum) (notice of 
Supervisory liability is especially necessary where the plaintiff seeks equitable relief, since it may be only the higher level official who is in a position to implement any affirmative corrective measures that may be ordered by the court. While lower courts, responsive to concerns that damage judgments are unfairly imposed absent a significant degree of blameworthiness in the defendant's conduct, have restricted the instances in which such liability would be assessed against supervisory officials, they have generally been more willing to grant equitable relief under section 1983, particularly where the plaintiff can demonstrate a pattern of unconstitutional conduct and the likelihood of its recurrence. ${ }^{107}$ But last Term, in Rizzo v. Goode ${ }^{108}$ the Supreme Court may have approved an even stricter standard for the issuance of equitable relief than for an award of damages against supervisory officials. Rizzo originated as a pair of section 1983 class actions brought to compel the Philadelphia Police Department to improve its fashion of handling citizen complaints as well as to cease violating the constitutional rights of Philadelphia citizens. ${ }^{109}$ The trial court, after finding a "pattern of frequent police violations" 110 of the rights of minority group members and those who could be classified as dissenters or protestors, ordered the defendant officials to implement a program for dealing with complaints that satisfied minimum constitutional standards. ${ }^{111}$ The order was affirmed by the Third Circuit. ${ }^{112}$ But the Supreme Court reversed, resting its holding on a number of

prior abusive actions and failure to take remedial measures); Williams v. Vincent, 508 F.2d 54I, 546 (2d Cir. 1974); Bishop v. Stoneman, 508 F.2d I224 (2d Cir. 1974) (deliberate indifference indicated by proof of six closely related incidents of negligent medical treatment).

In addition, lower courts have found supervisory liability where the responsible official either had a constitutional duty to take remedial action, or breached a duty to the plaintiff imposed on him by state law. See, e.g., Sims v. Adams, 537 F.2d 829, 831 (5th Cir. 1976); Landman v. Royster, 354 F. Supp. I302 (E.D. Va. 1973); Huey v. Barloga, 277 F. Supp. 864, 872-73 (N.D. Ill. 1967) (dictum).

${ }^{107}$ See, e.g., Lewis v. Kugler, 446 F.2d I343, I350 (3d Cir. I97I); Schnell v. City of Chicago, 407 F.2d 1084 (7th Cir. 1969) ; Lankford v. Gelston, 364 F.2d 97 (4th Cir. 1966) (en banc); Cottonreader v. Johnson, 252 F. Supp. 492 (M.D. Ala. 1966). See also Adams v. Pate, 445 F.2d 105, 107 n.2 (7th Cir. 197I) (dictum) (respondeat superior may be appropriate in actions for equitable relief).

${ }^{108} 423$ U.S. 362 (1976).

${ }^{109}$ Id. at 364-65 \& n.I.

${ }^{110}$ See Council of Organizations on Philadelphia Police Accountability \& Responsibility (COPPAR) v. Rizzo, 357 F. Supp. I280, 1318 (E.D. Pa. I973), aff'd in part, vacated and remanded in part sub nom. Goode v. Rizzo, 506 F.2d 542 (3d Cir. 1974), rev'd, 423 U.S. 362 (1976).

${ }^{111} \mathrm{See} 357$ F. Supp. at $1320-2 \mathrm{I}$.

${ }^{112}$ Goode v. Rizzo, 506 F.2d 542 (3d Cir. 1974). 
grounds, ${ }^{113}$ including the lack of any evidence that the supervisory officials had affirmatively implemented an unconstitutional policy, or ordered the lower officials' unconstitutional acts. ${ }^{114}$ If the Court's holding is transplanted into a rule that supervisors may be held liable for purposes of granting equitable relief only where they have affirmatively acted to further alleged abuses by their subordinates, then both the occasions in which negligent patterns of conduct will amount to constitutional deprivations, and those in which injunctive relief, based on patterns of negligent or intentional conduct by subordinates, will issue against supervisory officials to attempt to cure conceded systemic violations, will be severely limited..$^{115}$

2. Qualified Immunities: The Good Faith Defense. - The unqualified language of section 1983 could be read to impose strict liability on state and local governmental officials once a constitutional deprivation has been established. ${ }^{116}$ Following the holding in Monroe v. Pape ${ }^{117}$ that a requirement of specific intent to violate constitutional rights was not consistent with section I983's imposition of civil as opposed to criminal liability, ${ }^{118}$ the lower courts differed widely on the scope of the immunity or nature of defense ${ }^{119}$ - available to executive and adminis-

${ }^{113}$ Rizzo v. Goode, 423 U.S. 362 (1976).

${ }^{114}$ See id. at $373-77$. The Court also suggested the controversy in question might be too hypothetical to be justiciable, $i d$. at $37 \mathrm{I}-73$, and noted that there were serious federalism objections to federal courts ordering systemic equitable relief against the executive branches of state or local governments. See id. at 380 . See also The Supreme Court, 1975 Term, supra note 90, at 238-47.

115 See The Supreme Court, 1975 Term, supra note 90, at 243-47.

${ }^{116}$ See, e.g., Picking v. Pennsylvania R.R. Co., I5I F.2d 240 (3d Cir. 1945) (no immunity even for state judges), cert. denied, 332 U.S. 776 (I947), overruled by Bauers v. Heisl, 36r F.2d 58I (3d Cir. I966) (en banc); McShane v. Moldovon, I72 F.2d Ior6 (6th Cir. I949) ; Pierson v. Ray, 386 U.S. 547, 560 (I967) (Douglas, J., dissenting) ; Tenney v. Brandhove, 34I U.S. 367, 38I-83 (I95I) (Douglas, J., dissenting).

117365 U.S. I67 (I96I).

118 Id. at $\mathrm{I} 87$.

119 The term "qualified immunity," often used to describe the protection afforded state and local executive and administrative officials in the $\S$ r 983 damage action, is misleading. While an absolute immunity, now afforded judges, legislators, and prosecutors, see pp. II97-1204 supra, serves to defeat the $\S 1983$ action at the outset, so long as the protected official acts within the scope of her duties, the qualified immunity is, in fact, dependent upon the circumstances and motivations of the defendant's actions as established at trial, see Imbler v. Pachtman, 424 U.S. 409, 4I9 n.I3 (I976); Scheuer v. Rhodes, 4I6 U.S. 232, 242-49 (1974), is generally a matter of defense, see Pierson v. Ray, 386 U.S. 547, 555-58 ( I967); Glasson v. City of Louisville, 518 F.2d 899 (6th Cir. 1975); Knell v. Bensinger, 522 F.2d 720, 724 (7th Cir. 1975), and is ordinarily not determinable on a motion to dismiss under FED. R. Crv. P. I2(b) (6) but must await the further factual development attendant to a motion for summary judgment or trial. See Scheuer 
trative officials in the 1983 action. Responding to concerns, similar to those underlying the grant of absolute immunities, as to the possible impact of open-ended liability, ${ }^{120}$ most courts afforded such officials a form of qualified immunity, or "good faith defense," to actions for monetary damages. ${ }^{121}$ While such an immunity precludes damage liability for certain official acts concededly violative of individuals' constitutional rights, its scope, as defined by the Supreme Court, offers significantly less protection for most governmental officials than is provided at common law. ${ }^{122}$

The Supreme Court was first faced with the question of the appropriate scope of this qualified immunity in Pierson v. Ray. ${ }^{123}$ In that case, Chief Justice Warren indicated that the "background of tort liability" referred to in Monroe v. Pape ${ }^{124}$ included a

v. Rhodes, 416 U.S. 232, 249-50 (I974); Safeguard Mutual Ins. Co. v. Miller, 472 F.2d 732, 733-34 (3d Cir. 1973) ; Greenlaw v. California Dep't of Benefit Payments, 413 F. Supp. 420, 425-27 (E.D. Cal. 1976).

${ }^{120}$ See pp. I197-I 204 supra; pp. I217-27 infra. See generally Note, The Doctrine of Official Immunity Under the Civil Rights Acts, 68 Harv. L. Rev. I229 (1955); Jennings, Tort Liability of Administrative Officers, 2I MINN. L. Rev. 263 (1937).

${ }^{121}$ See, e.g., Fidtler v. Rundle, 497 F.2d 794 (3d Cir. 1974) (apparent absolute immunity for executive official engaging in discretionary action); Krause v. Rhodes, 47I F.2d 430, 437-40 (6th Cir. 1972) (absolute immunity for state governor and university president), rev'd and remanded sub nom. Scheuer v. Rhodes, 416 U.S. 232 (1974); McLaughlin v. Tilendis, 398 F.2d 287 (7th Cir. I968) (immunity for school officials if they show their actions were justifiable); Smith v. Losee, 485 F.2d 334, 344 (Ioth Cir. 1973) (en banc) (immunity for good faith action taken in absence of malice), cert. denied, 4I7 U.S. 908 (1974); Strickland v. Inlow, 348 F. Supp. 244 (W.D. Ark. 1972) (school officials immune for all but malicious acts), rev'd, 485 F.2d 186 (8th Cir. 1973) (immunity for acts, judged objectively, taken in good faith), vacated and remanded sub nom. Wood v. Strickland, 420 U.S. 308 (1975) (good faith defense incorporating both objective and subjective elements). See generally Note, supra note I20.

${ }^{122}$ At common law, judges, legislators, high executive officials, and, in most cases, prosecutors enjoyed an absolute immunity for actions taken in the course of their official duties. Lower administrative officials were granted immunity for so-called "discretionary acts" requiring personal deliberation, decision, and judgment, so long as such acts were done honestly and in good faith, i.e., without malice or improper purpose. For "ministerial acts" involving little personal judgment, the official acted improperly at her peril. See generally W. Prosser, HANDBOOK OF THE LAW OF TORTS $\$ 132$ (4th ed. I971); Jennings, supra note I20; see also Scheuer v. Rhodes, 416 U.S. 232 (1974); Wood v. Strickland, 420 U.S. 308 (1975); p. I212 infra (immunity even for high executive officials and for discretionary acts not absolute in $\S 1983$ context).

${ }^{123} 386$ U.S. 547 (1967).

${ }^{124} I d$. at 556-57 (citing Monroe v. Pape, 365 U.S. I67, I87 (I96I)). Monroe, like Pierson, involved alleged unconstitutional acts of police officers; the Court in Pierson concluded that the opinion in Monroe had decided no question of immunity, since in Monroe the

police officers did not choose to ... defend the case on the hope that they could convince a jury that they believed in good faith that it was their duty 
defense to a common law action for false arrest which would acquit a police officer who acted with good faith and probable cause in making an arrest even though the suspect was later acquitted or the statute permitting the arrect was subsequently ruled unconstitutional. ${ }^{125}$ This defense was also available to police officers in section 1983 actions. ${ }^{126}$

The class of state executive officers to whom the Supreme Court was willing to extend this qualified immunity was broadened in the cases of Scheuer v. Rhodes ${ }^{127}$ and Wood v. Strickland,${ }^{128}$ opinions which also served to define in some measure the nature of the good faith defense. In Scheuer, personal representatives of students killed during the disorders at Kent State University brought suit under section 1983 against the Governor of Ohio, officials of the national guard, and the president of Kent State. The district court dismissed the suit as barred by the eleventh amendment and on the ground that "executive immunity" shielded the defendants; the court of appeals agreed, finding that the defendants occupied positions requiring wide discretion, ${ }^{129}$ and that "since the courts have granted to themselves absolute immunity, it would seem incongruous for them not to extend the same privilege to the Executive." ${ }^{130}$

Recognizing the difficulties necessarily entailed by any at-

to assault Monroe and his family .... [T]hey sought dismissal . . . contending ... that their activities were so plainly illegal under state law that they did not act [under color of state law] . . . as required by $\S 1983$.

386 U.S. at 556 .

${ }^{125} 386$ U.S. at $556-57$.

${ }^{126}$ Id. at 557 . The mere assertion of the good faith defense by police officer defendants will not suffice, however, since the question is one for the jury, which must determine that "the officers reasonably believed in good faith" that their actions were constitutional. Id.

By referring to the "background of tort liability," the Court clearly did not contemplate reference to the common law of any given state, but rather, as in Tenny v. Brandhove, 34I U.S. 367 (I95I), see p. II99 supra, to the "prevailing view [of the common law] in this country." 386 U.S. at 555. Further, while Pierson is ambiguous on this point, the prevailing common law view is no longer decisive as to the availability of a $\S$ I 983 defense: that view must be considered in light of the policies and purposes of the $\S$ r 983 action to determine whether importation of the defense, or allowance of a defense where the common law provides none, is appropriate. See, e.g., Imbler v. Pachtman, 424 U.S. 409, 424-29 (I976); Wood v. Strickland, 420 U.S. 308, 318-22 (1975); Scheuer v. Rhodes, 4I6 U.S. 232, 238-49 (1974). Compare Whirl v. Kern, 407 F.2d 781, 790-92 (5th Cir.), cert. denied, 396 U.S. 901 ( 1969 ) (good faith no defense to false imprisonment at common law, so no defense under $\S$ I983), with Bryan v. Jones, 530 F.2d I 2 Io (5th Cir. 1976) (en banc) (overruling Whirl and holding good faith defense generally available in $\$ 1983$ damage actions).

${ }^{127} 4$ I 6 U.S. 232 (1974).

128420 U.S. 308 (I975).

${ }^{129}$ Krause v. Rhodes, 47I F.2d 430, 433, 437 (6th Cir. 1972), rev'd sub nom. Scheuer v. Rhodes, 416 U.S. 232 (1974).

${ }^{130}$ Id. at 437. 
tempt to hold the highest executive officer of a state liable for his discretionary decisions, the Supreme Court nonetheless declined to find the governor absolutely immune. ${ }^{131}$ The section 1983 action was designed to "enforce provisions of the Fourteenth Amendment against those who carry a badge of authority of a State"; indeed, the danger from which it shields the citizen is the "misuse of power . . . made possible only because the wrongdoer is clothed with the authority of state law . . ."."132 Hence, the acts of a governor could not be treated as a "supreme and unchangeable edict, overriding all conflicting rights"; $; 3$ rather, the imperatives of the section 1983 action in combination with the necessities of discretionary executive conduct

suggest that, in varying scope, a qualified immunity is available to officers of the executive branch of government, the variation being dependent upon the scope of discretion and responsibilities of the office and all the circumstances as they reasonably appeared at the time of the action on which liability is . . . based. It is the existence of reasonable grounds for the belief formed at the time and in light of all the circumstances coupled with good-faith belief, that affords a basis for qualified immunity. ${ }^{134}$

Scheuer left open a number of questions about the scope of the good faith defense. In particular, the term "good faith" itself assumed a more objective or subjective meaning, depending on which court was interpreting it. ${ }^{135}$ This problem reached the Supreme Court in Wood v. Strickland, ${ }^{136}$ a suit in which the trial court had applied a subjective meaning of "good faith" and

${ }^{131} 416$ U.S. $232,238-49$ (1974).

132 Id. at 243 (quoting Monroe v. Pape, 365 U.S. 167, I72, 184 (I96I)). Thus, "government officials, as a class, could not be totally exempt, by virtue of some absolute immunity, from liability under [ $\S$ I 983 's] terms." Id. The Court was thus forced to balance the policies underlying the executive immunity at common law, which it identified as

the injustice, particularly in the absence of bad faith, of subjecting to liability an officer who is required .... to exercise discretion ... . [and] the danger that the threat of such liability would deter his willingness to execute his office with the decisiveness and the judgment required by the public good, with the purposes of $\S 1983$.

id. at 240 .

${ }^{133}$ Id. at 248 (quoting Sterling v. Constantin, 287 U.S. 378,397 (1932)).

${ }^{134} 4 \mathrm{r} 6$ U.S. at $247-48$. Under such a standard, the scope of the immunity enjoyed by high level officials would be wider than that enjoyed by police officers, "since the options which a chief executive . . . must consider are far broader and far more subtle than those made by officials with less responsibility . . ." Id. at 247.

${ }^{135}$ See, e.g., Wood v. Strickland, 420 U.S. $308,315-18 \&$ n.7 (1975), and cases cited therein.

${ }^{136} 420$ U.S. 308 (1975). 
the court of appeals an objective one. ${ }^{137}$ Not surprisingly, the Supreme Court held that the good faith standard encompasses both a subjective and an objective element. Clearly, the defendant official must not have acted out of malice; moreover, "an act violating . . . constitutional rights can be no more justified by ignorance or disregard of settled, indisputable law . . . than by the presence of actual malice." ${ }^{138}$

Wood and Scheuer taken together make it clear that the "immunity" extended to state executive officials is in fact a defense - a defense on the merits, involving proof of both state of mind and reasonableness of conduct. ${ }^{139}$ The first part of the defense has not caused many problems for courts; when there are conflicting allegations as to whether or not the defendant acted out of malice, the issue can readily be decided by the jury. What has proved more difficult has been to define the independent content of the reasonableness standard.

The contours of this standard are defined most broadly in Scheuer, which held that the showing required to satisfy it depends "upon the scope of discretion and responsibilities of the office and all the circumstances as they reasonably appeared ...."140 In part, this approximates the "reasonable man" test of negligence law; but it includes the additional element of the defendant official's range of discretion and the need to prevent undue inhibition of its exercise. ${ }^{141}$

${ }^{137}$ Id. at $33^{1-14}$. The subjective standard would allow liability only where it could be determined that the defendants acted with malice; the objective test utilized by the court of appeals would have imposed liability where it is "established that the defendants did not, in the light of all the circumstances, act in good faith." Id. at 3 I 4 .

${ }^{138} I d$. at $32 \mathrm{I}-22$. The Court specifically held that no immunity would attach if the school official

knew or reasonably should have known that the action he took ... would violate the constitutional rights of the student affected, or if he took the action with the malicious intention to cause a deprivation of constitutional rights or other injury to the student. That is not to say that school board members are "charged with predicting the future course of constitutional law."

Id. at 322 (citation omitted).

139 See note I I 9 supra.

${ }^{140} 4$ I 6 U.S. 232,247 (1974).

141 See generally W. Prosser, Handbook of the Law of Torts $\$ 32$ (4th ed. I97 I); The Supreme Court, 1974 Term, 89 Harv. L. Rev. 47, 2 19, 222 (1975). Of course, to the extent that traditional negligence law contemplates a judgment of the defendant's action as measured against that of a reasonable person in similar circumstances, see W. Prosser, supra, at $\mathrm{I}_{5} \mathrm{I}$, the duties and discretion of the defendant would constitute a part of the standard. But Scheuer would seem to compel a judgment that such factors be given special emphasis, since the qualified immunity it provides is designed to be responsive to fears of unduly inhibiting discretion on the part of high-ranking government officials, and to avoid unduly "second 
The Supreme Court's opinion in Wood can best be read as broadening the potential section 1983 damage liability of state executive officials ${ }^{142}$ by adding to the reasonableness test of Scheuer a provision for imputing malice where the official acts so as to violate clearly settled constitutional rights. ${ }^{143}$ But paradoxically, the opinion is also subject to an interpretation which would significantly reduce the possibility of damage liability: the only test actually articulated is whether the official acted maliciously, or in violation of rights he knew or reasonably should have known existed, with the category of rights encompassed under the latter test seemingly limited to those clearly established ${ }^{144}$ since the official cannot be "charged with predicting the future course of constitutional law." 145 Under the narrowing interpretation, the Scheuer reasonableness test would have no independent content, since in the absence of malice, unless rights of the clearly settled category were violated, no liability could be found. ${ }^{146}$

guessing" official decisionmaking. See Scheuer v. Rhodes, 4 I6 U.S. $232,238-49$ (1974).

${ }^{142}$ While the Court in Wood indicated that the immunity it articulated in its opinion was applicable "in the specific context of school discipline," 420 U.S. at 322, the test has been applied by the Court to officials at a state mental hospital, see O'Connor v. Donaldson, 422 U.S. 563, 576-77 (1975), and by lower courts to a wide variety of executive and administrative personnel. See cases cited note 150 , infra.

${ }^{143}$ As the Court stated, "an act violating ... constitutional rights can be no more justified by ignorance or disregard of settled, indisputable law . . . than by the presence of actual malice." 420 U.S. at 32 I. Mr. Justice Powell's dissent, joined by three other members of the Court, see 420 U.S. at 327-3I, criticized the majority opinion on just this ground: by equating ignorance of settled constitutional rights with malice, the dissent argued, the majority had departed from the more appropriate general reasonableness standard of Scheuer to impose a "more severe . . . standard significantly enhancing the possibility of personal liability," id. at 33I, by permitting a damage award where the court finds "that a good-faith belief as to the applicable law was mistaken ....." Id. at 329.

144 The question who is to make the "clearly settled" determination has been answered in two different ways, neither of which appears unreasonable. One commentator has noted that resolution of this issue "would appear to require a decision by a judge," see The Supreme Court, 1974 Term, supra note I4I, at 222; on the other hand, at least one court of appeals has apparently approved a different procedure: expert witnesses, such as law professors, are called to present testimony on the question, which is then left to the jury. See Laverne v. Corning, 522 F.2d I144 (2d Cir. 1975). A court adopting the latter procedure should be careful to instruct the jury that it must make separate determinations on the issues of whether clearly established rights were violated, whether the defendant's conduct was malicious, and whether the defendant's conduct, if violative of constitutional rights, was reasonable under all the circumstances.

145420 U.S. at 322.

${ }^{146}$ Indeed, one commentator has interpreted Wood to require that the judge determine that there has been a violation of "clearly settled" constitutional rights 
But given the Court's citation of Scheuer and its apparent readiness to impute malice - leading to the possibility of an award of punitive damages ${ }^{147}$ - where the official ignores clearly settled constitutional rights, it is arguable that the Court intended to retain the Scheuer reasonableness test for damage liability. ${ }^{148}$ Indeed, many lower courts have taken this view, considering a wide variety of factors to determine whether the official action was reasonable. ${ }^{149}$ Under this view, the "clearly settled rights" prong of the liability test should be utilized sparingly, as it has in fact been used by lower courts since $\operatorname{Wood}^{150}$ to find liability,

before any question of liability can reach the jury, see Supreme Court, 1974 Term, supra note $14 \mathrm{I}$, at 223 , with the question of reasonableness then submitted to the jury. But this view overlooks both the language of the Wood opinion equating ignorance of clearly settled rights with malice, see 420 U.S. at $32 \mathrm{I}-22$, and the provision for a finding of liability based solely on malice, see id.

${ }^{147}$ See, e.g., Palmer v. Hall, 517 F.2d 705 (5th Cir. 1975) ; Batista v. Weir, 340 F.2d 74 (3d Cir. I965) (punitive damages available in $\S$ I 983 action where defendent acts maliciously).

${ }^{148}$ See 420 U.S. at $313^{-22}$. Offering further support for the continued validity of the reasonableness test, the Court stated:

The immunity must be such that ... officials understand that action taken in the good-faith fulfillment of their responsibilities and within the bounds of reason under all the circumstances will not be punished and that they need not exercise their discretion with undue timidity.

Id. at 32 I. See also Imbler v. Pachtman, 424 U.S. 409, 4I9 n.I3 (I976) ("fate of an official with qualified immunity depends upon the circumstances and motivations of his actions, as established by the evidence at trial").

${ }^{149}$ For cases applying a Scheuer-like test of reasonableness, see Boscarino v. Nelson, 5 I8 F.2d 879 (7th Cir. 1975); Clark v. Ziedonis, 513 F.2d 79 (7th Cir. 1975) (law permits use of force to apprehend fleeing felon; question of reasonableness is for finder of fact); Jones v. Marshall, 528 F.2d I32 (2d Cir. I975); Stephenson v. Gaskins, 53 I F.2d 765 (5th Cir. 1976) (qualified immunity depends upon circumstances and motivations of defendant's actions as established at trial); Bell v. Wolff, 496 F.2d I252 (8th Cir. 1974) (fact that warden had sought to be progressive and remedy prison situation, that there was no specific legal guidance on the issue in question, and that no malice appeared relevant to defense); Bryan v. Jones, 530 F.2d I210 (5th Cir.) (en banc), cert denied, $97 \mathrm{~S}$. Ct. I74 (1976); Laverne v. Corning, 522 F.2d II44 (2d Cir. I975) (defendants' belief in lawfulness of conduct must be reasonable; speed with which they must act is one factor for jury consideration); Handverger v. Harvill, 479 F.2d $5^{\mathrm{I}} 3$ (9th Cir.), cert. denied, 4I4 U.S. 1072 (1973) (reliance on advice of attorney general, action by state court, and fear of violence support reasonableness of actions).

${ }^{150}$ For cases finding the constitutional right in question "unsettled," see Knell v. Bensinger, 522 F.2d 720 (7th Cir. 1975) (while right of access by prisoners to courts settled, right of access during period of disciplinary isolation not settled); Mims v. Board of Educ., 523 F.2d 7II (7th Cir. 1975) (defense that right to due process prior to employment termination not settled at time of defendant's unconstitutional conduct); Hutchison v. Lake Oswego School Dist., 5ig F.2d 96I (9th Cir. 1975), cert. denied, 97 S. Ct. 73I (1977) (fact that courts split on issue and that defendant relied on attorney's advice enables official to escape liability) ; Sullivan v. Meade Indep. School Dist., 530 F.2d 799 (8th Cir. 1976) (right to privacy ambiguous, firing of school employee for living unmarried with another not 
apart from other factors indicative of reasonableness of official action, where the character of the right violated is so clearly settled that ignorance of it simply cannot be excused..$^{151}$

Absent violation of such a right - as when the right is newly articulated in the course of the damage action, involved in controversy in the lower courts, or extended to a new and different factual context - the jury should be permitted to inquire into the reasonableness of the official conduct under the Scheuer standard. ${ }^{152}$ Otherwise, the 1983 damage action will be deprived of much of its remaining vitality; officials will be able to escape liability for unreasonable acts, violative of constitutional rights, by showing that they did not act maliciously and by resort to formalistic arguments that the right violated was not of suffi-

violation of settled rights); Sapp v. Renfroe, 51 I F.2d I72 (5th Cir. 1975) (right unsettled since only one case from another circuit recognized it and that case included cogent dissent); Poindexter v. Woodson, 5 Io F.2d 464 (Ioth Cir.) (use of strip cells authorized by statute; no court with jurisdiction over defendant had previously declared practice improper; long-standing custom in state; eighth amendment guarantee ambiguous; right not settled), cert. denied, 423 U.S. 846 (I975); Collins v. Bensinger, 374 F. Supp. 273 (N.D. Ill.) (no Supreme Court opinion on issue; division of circuits; this decision settles right for future), aff'd, 514 F.2d 442 (7th Cir. 1974), cert. denied, 422 U.S. 1058 (1975). But see Glasson v. City of Louisville, 5 I8 F.2d 899 (6th Cir.) (while urgency of situation is factor to be considered, subjective good faith test would foster ignorance, or feigned ignorance, of law; order to destroy anti-Nixon picket signs clearly unconstitutional), cert. denied, 423 U.S. 930 (1975); Schiff v. Williams, 519 F.2d 257 (5th Cir. 1975) (case decided on point two months prior to action of firing student newspaper editors put defendant on notice; should have consulted attorney; first amendment right clearly settled); Janetta v. Cole, 493 F.2d I334 (4th Cir. 1974) (right to circulate letter of complaint among fellow employees clearly settled); State v. McFetridge, 484 F.2d II69 (7th Cir. I973) (while precise process rights with regard to demonstration permit applications not settled, right to quick determination settled).

${ }^{151}$ Such a view would serve the additional symbolic function of assuring citizens that government officials cannot claim ignorance of clearly established law, particularly where the law in question is controlled by the mandates of the Constitution. See generally The Supreme Court, 1974 Term, supra note I4I, at 222 (1975). It would also have the desirable consequence of not imputing malice to government officials absent violation of a narrowly defined area of rights and of permitting courts to avoid formalistic and often contorted determinations of which rights are "clearly settled." See note I50 supra.

${ }^{152}$ The question for the jury in such a case, see Wood v. Strickland, 420 U.S. 308, 322 (I975); O'Connor v. Donaldson, 422 U.S. 563, 576-77 (1975), would be whether, under all the circumstances, in light of the fact that officials cannot be expected to be predictors of the course of constitutional law, see Wood v. Strickland, 420 U.S. at 322 , the official knew or reasonably should have known his action would violate the $\$ 1983$ plaintiff's constitutional rights. See also O'Connor v. Donaldson, 422 U.S. at $578-79$ (Burger, C.J., concurring) (such factors as apparent prior state court approval of defendant's actions relevant to consideration of $\S 1983$ liability); cases cited note 149 supra. 
ciently settled legal status to warrant an imputation of malice. ${ }^{153}$ They may do so regardless of the circumstances surrounding the actions in question, the alternative courses of action open, or even the presence of an opportunity, upon reasonable inquiry, to have discovered that the questioned action would more likely than not be declared violative of the Constitution.

\section{The Section 1983 Damage Action}

The immunity rules and the requirements of proof discussed in the preceding Section combine to limit severely both the occasions on which individual injury at the hands of the state will be considered a constitutional deprivation and those on which any damage recovery will result. This Section will seek to isolate and to evaluate the underlying concerns whose compromise has resulted in the present shape of the section 1983 damage action. The next Section will then deal with the evolving scope of the 1983 injunctive action - the "public law" action.

Any analysis of the doctrines governing damage recovery in I983 actions must begin with municipal and governmental immunities. The Court's decision in Monroe v. Pape ${ }^{154}$ that a municipality is not a "person" for purposes of section $1983^{155}$ has, more than any other single ruling, limited the utility of 1983 damage actions as a means of vindicating individual claims against state-inflicted injury. ${ }^{156}$ Compensation to an individual injured by state action, if paid by the government, may be justified as a means of spreading the cost of official wrongdoing among all citizens rather than allowing the cost to fall on the unlucky few. ${ }^{157}$ Indeed, even the individual injured by an unintentional

${ }^{153}$ See cases cited note 150 supra; The Supreme Court, 1974 Term, supra note I4I, at 223-25 (1975). Should the narrow view of the Wood holding ultimately prevail, however, it might be expected that a jury confronted with baldly unreasonable action on the part of a government official, and a sympathetic plaintiff, will be moved to find malice in order to impose liability. Cf. Harper v. Cserr, 544 F.2d I I2 I, II25 (Ist Cir. I976) (dictum) (right not settled, but perhaps trier of fact may infer malice from wanton neglect).

${ }^{154} 365$ U.S. I67 (I96r).

${ }^{155} \mathrm{Id}$. at $187-9 \mathrm{I}$.

${ }^{156}$ See generally Kates \& Kouba, Liability of Public Entities Under Section r983 of the Civil Rights Act, 45 S. CAL. L. Rev. I3 I (1972); Comment, Toward State and Municipal Liability in Damages for Denial of Racial Equal Protection, 57 Calif. L. Rev. II42 (I969); Note, Damage Remedies Against Municipalities for Constitutional Violations, 89 HARv. L. REv. 922 (1976).

${ }^{157}$ See generally Michelman, Property, Utility, and Fairness: Some Thoughts on the Ethical Foundations of "Just Compensation" Law, 80 HaRv. L. Rev. II65 (1967). Cf. Bivens v. Six Unknown Named Agents of Federal Bureau of Narcotics, 403 U.S. 388, 39I-92 ( I97 I):

Respondents seek to treat the relationship between a citizen and a federal 
or unavoidable act of a public official which might be considered a background cost of citizenship may have some claim against the government that compensation should be paid and the costs of his injury spread. ${ }^{158}$ It is more difficult to justify a damage award, however, where the issue is not whether costs should be spread among all citizens but rather whether they should be shifted from the injured individual to the individual official who may be considered responsible. In this context, it is hardly surprising that notions of fault or blameworthiness have emerged to define a deprivation and that good faith has been accepted as a defense to individual damage liability. ${ }^{159}$ Unless we are willing to treat state and local officials as if they were the government (on the grounds that they may well be indemnified for their loss) and at the same time adhere to the rule that governmental entities themselves are immune, ${ }^{160}$ there appears to be little justification in terms of fairness for requiring compensation when the official actor is not to blame for the injury. ${ }^{161}$ While this reasoning does not itself mandate refusal to recognize negligent conduct as a violation of section $\mathrm{I} 983$, it does support the introduction of some miminal standards of fault.

A similar conclusion is reached if section 1983 damage actions are viewed as a means of deterring injurious conduct. Damage remedies imposed on governmental entities could serve to prevent injuries to individuals by the system as a whole. ${ }^{162}$

agent unconstitutionally exercising his authority as no different from the relationship between two private citizens. In so doing, they ignore the fact that power, once granted, does not disappear like a magic gift when it is wrongfully used. An agent acting .... in the name of the United States possesses a far greater capacity for harm than an individual trespasser exercising no authority other than his own.

${ }^{158}$ See Note, supra note 156 , at 957.

${ }^{159}$ This is true because the question in such cases is not whether it is unfair to concentrate the costs of social action on any single individual, see Michelman, supra note 157 , at $1216-18$, but rather upon which of two individuals those costs will be concentrated.

160 See pp. I191-97 supra.

${ }^{161} \mathrm{Cf}$. Michelman, supra note $\mathrm{I57}$, at $\mathrm{I} 2 \mathrm{16}$. ("Society has not yet placed itself under any systematic discipline designed to assure people of compensation for all economic losses inflicted by forces regarded as beyond social control, such as earthquake or plague.").

${ }^{162}$ The threat of damage judgments against the government unit might well induce supervisory officials to design procedures, internal rules, and training programs so as to minimize misconduct. See, e.g., Williams v. Brown, 398 F. Supp. I55, I59 (N.D. Ill. I975) ; Kates \& Kouba, supra note 156, at 140-4I ; Note, supra note 156 , at 927. See also Amsterdam, Perspectives on the Fourth Amendment, 58 Mins. L. Rev. 349, 409-39 (I974). In addition, a damage remedy might well be considered less intrusive on the operations of local government units than injunctive relief: not only are the local units free of the continuing supervision which seems to have troubled the Court in recent cases, see Rizzo v. Goode, 423 U.S. 362 (I976) ; O'Shea v. Littleton, $4 \mathrm{I} 4$ U.S. 488 , 502 (1974), but they are also left with full dis- 
Whether imposed only where the injury could efficiently have been avoided or on the basis of strict liability to achieve full cost internalization, such remedies should, assuming decisionmakers are rational, lead municipalities to take steps to reduce injuries whenever the steps appear less costly than the injuries they prevent. ${ }^{183}$ While the problems of valuation and prediction ${ }^{164}$ make it unrealistic to expect perfectly rational deterrence, it is clear that the immunities of government entities substantially undermine the effectiveness of section I983 damage actions as deterrents. To be sure, damages may deter individuals. But many injuries inflicted by the state may be traceable not to the decision of any single official, but rather to the actions of one or more individuals in a context of procedures, rules, and resources which themselves contribute to the injury. ${ }^{165}$ While the state system as a whole may be responsible for the costs which result, it is difficult to isolate any single individual upon whom a damage award would serve as an effective deterrent. ${ }^{166}$ As a result, if damages are considered a deterrent, and if liability must be individualized, recovery should be limited at least to cases in which the injury was one the defendant could have and should have prevented. This would leave undeterred those injuries which, while properly charged to the state, cannot be considered the fault of any single individual.

Thus, with respect to both compensation and deterrence, no-

cretion to make the basic choices as to policy and implementation of any remedial scheme, see pp. I227-50 infra.

${ }^{163}$ See generally G. Calabresi, The Costs of Accidents (1970).

${ }^{164}$ See Lewis v. Kugler, 446 F.2d 1343, 1350 (3d Cir. 197I); Lankford v. Gelston, 364 F.2d 197, 202 (4th Cir. 1966) (en banc); p. I226 infra (problems of measuring damages).

${ }^{165}$ See Note, Rethinking Federal Injunctive Relief Against Police Abuse: Picking Up the Pieces After Rizzo v. Goode, 7 Rur.-CAM. L.J. 530, 532 (1976) (suggesting that police misconduct should be viewed "as a function of institutional rather than individual flaws"); Note, supra note 156 , at 957 (in many cases "responsibility for the wrong is diffused throughout various parts of the government rather than attributable to the particular individual who operates most directly upon the victim").

${ }^{166}$ In Burton v. Waller, 502 F.2d $126 \mathrm{I}$ (5th Cir. 1974), cert. denied, 420 U.S. 964 (1975), suit was brought against 69 individual state and city police officers, their superiors, and the city and state for damages arising out of the shootings at Jackson State University. Although the court found that "[ $t]$ he barrage of gunfire far exceeded the response that was appropriate," $i d$. at $127 \mathrm{I}$, it upheld a jury verdict for all defendants. The state was found immune under the eleventh amendment and state law, the city under Monroe. Id. at 1273 . The court held that the conduct of some of the individuals was not outside their privilege of self-defense under state and common law tort doctrine, id. at $1275-80$, while verdicts for the others were upheld because it was impossible to determine who had fired the shots which killed and wounded the students, id. at $\mathrm{I} 28 \mathrm{I}-86$. 
tions of fault or blameworthiness emerge as the inevitable product of a scheme of individualized liability. They reflect the fact that it would be both unfair and ineffective to require an individual who was not at fault to bear the costs of injuries resulting from his action. And the consequence is that some injuries for which compensation might fairly be demanded from the government and some costs whose incursion might be prevented by requiring the government to pay damages are left uncompensated and undeterred. ${ }^{167}$

Keying 1983 damage liability to individual fault, however, does not itself explain why negligence is not sufficient to trigger recovery or why qualified immunities should be available to foreclose recovery where a violation is proved to be the result of the defendant's intentional conduct. Indeed, it is in these respects that the section 1983 damage action differs from the traditional model of biparty civil litigation with which it is otherwise consistent. ${ }^{168}$ These differences respond not to the mere fact that liability, as in the traditional private model, is individualized; rather, they reflect concerns about the undesirability of "federalizing" tort law and the possible adverse impact of broad damage liability both on governmental officials personally and on the proper functioning of the state governmental machinery itself.

The specter of "general federal tort law" ${ }^{169}$ resulting from a recognition of liability for negligence is more often invoked than explained. Conceivably, a number of factors may be supporting the reluctance of courts to create through section 1983 a remedy encompassing the broad range of action which, if done privately, would give rise to a state tort claim. For example, there may be a notion that harms of a less than egregious nature should not give rise to federal interference; requiring such claims to be dealt with as state torts reduces the frequency of federal intrusions into state affairs and allows the states themselves to correct the ex-

${ }^{167}$ Cf. Carter v. Carlson, 447 F.2d 358, $367 \&$ n.27 (D.C. Cir. 1971), rev'd on other grounds sub nom. District of Columbia v. Carter, 409 U.S. 418 (1973) ("With respect to some government functions, the threat of individual liability would have a devastating effect, while the threat of government liability would not significantly impair performance.").

The trend in recent state court decisions has been towards expanding municipal tort liability. See, e.g., Ayala v. Philadelphia Bd. of Pub. Educ., 453 Pa. 584, 305 A.2d 877 (1973) (abolishing immunity of local government units). See generally W. PRosser, supra note I4I, at 985 .

168 The Court's logic in Bivens v. Six Unknown Named Agents of Federal Bureau of Narcotics, 403 U.S. 388, 391-92 (I97I), see note ' 57 supra, would suggest that the standard of liability in suits against government officials ought to be stricter, not more relaxed.

${ }^{169}$ See Paul v. Davis, 424 U.S. 693, 70r (1976); Shapo, Constitutional Tort: Monroe v. Pape, and the Frontiers Beyond, 60 Nw. U.L. Rev. 277 (1965). 
cesses of their officials. ${ }^{170}$ The problem with this argument is twofold. First, it is not at all clear that claims of official negligence, though they may arise with some frequency, lead to interference that is qualitatively substantial in any real sense. The actions are directed at individuals, and the court's role, at least initially, appears to be a limited one in terms of both the likely significance of the issues raised in any particular case and the likely impact of relief orders. ${ }^{171}$ Second, the fact is that a failure to recognize a federal cause of action does not generally lead to self-correction by state courts in any traditional sense; in many states, tort claims against officials will be dismissed under broader standards of immunity than those governing 1983 claims. ${ }^{172}$

Alternatively, the view that state tort law should not be federalized may respond not to a reluctance to have federal courts adopt the standards of tortious conduct established by state law but rather to a concern that broader federal enforcement of section 1983 would deprive each state of the freedom to decide, for example, that no recovery is appropriate for negligent acts committed by state officials. The federalization of state tort law, in this sense, would not only impose new constraints on individual officials; it would also limit the power of the states in their role of lawmakers and in their attempts to enforce substantive policy decisions. ${ }^{173}$ But if this analysis is correct, it does not mean that negligence ought never to serve as a basis for recovery in federal court; rather, it suggests that the federal courts, analogizing to the due process cases grounded in state-created entitlements, ${ }^{174}$ might justifiably look to state law in order to determine whether the state officials in question owe a duty of care to individuals in the plaintiff's position. ${ }^{175}$

${ }^{170}$ See Monroe v. Pape, 365 U.S. 167, 243 (196r) (Frankfurter, J., dissenting); Note, Limiting the Section 1983 Action in the Wake of Monroe v. Pape, 82 Harv. L. REV. 1486 ( 1969 ).

${ }^{171}$ See infra pp. 1271-72 infra.

${ }^{172}$ See note 167 . A similar argument might be premised on the need to reduce the federal caseload, but it seems no more persuasive. See p. I 72 supra.

${ }^{173}$ Such an argument would derive support from a broad reading of the values proterted by the Younger doctrine. See pp. I282-87 infra.

${ }^{174}$ See, e.g., Arnett v. Kennedy, 4I6 U.S. I34 (1974); Perry v. Sindermann, 408 U.S. 593 (1972) ; Board of Regents v. Roth, 408 U.S. 564 (1972); Goldberg v. Kelly, 397 U.S. 254 ( 1970 ).

${ }^{175}$ At some point, of course, the fourteenth amendment places a limit on the states' ability to make choices of this nature. See pp. II8I-82 supra. One might argue, relying on those cases holding supervisors liable under $\$$ I 983 where a pattern of negligent conduct by their subordinates is established, see p. 1 207 note 106 supra, that the state should not be free under the fourteenth amendment to choose effectively to condone negligent conduct by state officers by failing to impose any duty of care. 
The policies underlying good faith defenses, on the other hand, are relevant not to determining whether a constitutional violation has occurred but rather to the question whether damages will be granted for an established deprivation. ${ }^{176}$ From the plaintiff's perspective, of course, the distinction may be irrelevant to ultimate disposition: in either case, he may be unable to recover damages. But whether the issue goes to the existence of a deprivation or to the question of immunity directly affects the evidentiary burden he bears: in the former case, the burden of production and persuasion rests with him; in the latter, it rests with the defendant official. ${ }^{177}$

Good faith defenses are said to rest on deeply felt concerns that

[o]fficials of government should be free to exercise their duties unembarrassed by the fear of damage suits in respect of acts done in the course of those duties - suits which would consume time and energies which would otherwise be devoted to governmental service and the threat of which might appreciably inhibit the fearless, vigorous, and effective administration of policies of government. ${ }^{178}$

Certainly, there can be little doubt that as a general matter, government officials must inevitably make numerous discretionary decisions, and that the process of doing so may well not be enhanced by the frequent presence of the decisionmakers as defendants to 1983 actions. But this does not distinguish public officials from the run of private decisionmakers, who must face the threat of tort claims unaided by good faith defenses. In the case of private parties, the availability of such mechanisms as dismissal on the pleadings for failure to state a claim ${ }^{179}$ and summary judgment, ${ }^{180}$ and the costs to plaintiffs of initiating suits and pursuing their claims, are generally considered sufficient on balance to alleviate any burden of defending frivolous actions. ${ }^{181}$

${ }^{176}$ See pp. I 209-1 7 supra.

${ }^{177}$ See Pierson v. Ray, 386 U.S. 547, 555 (I967); p. I 209 \& n.I I9, p. I 2 I3 supra (qualified immunity in fact a defense based on good faith).

${ }^{178}$ Barr v. Matteo, 360 U.S. 564, 571 (1950) (plurality opinion) (Harlan, J.) ; see Gregoire v. Biddle, I77 F.2d 579, 58I (2d Cir. 1949) (L. Hand, J.), cert. denied, 339 U.S. 949 (I950); Jennings, Tort Liability of Administrative Officers, supra note 120 , at $27 \mathrm{I}$; Note, supra note 120.

${ }^{179}$ Fed. R. Civ. P. 12 (b) (6).

${ }^{180}$ FED. R. Crv. P. 56.

${ }^{181}$ The Code of Professional Responsibility also serves as a means of discouraging frivolous actions. The Code provides:

In his representation of a client, a lawyer shall not:

( I) File a suit, assert a position, conduct a defense, delay a trial, or take other action on behalf of his client when he knows or when it is obvious that such action would serve merely to harass or maliciously injure another. 
Indeed, in the private sector, positive value is attached to the fact that the threat of suits will encourage decisionmakers to exercise their discretion in ways which are likely to cause the least injury to other individuals. If good faith defenses are justifiable as applied to government officials, therefore, the reason must be differences in the nature of the decisions or decisionmakers which render the possibility of suits more harmful and the effect on behavior less desirable than is true with respect to private individuals.

First, the availability of good faith defenses has been supported as a means of furthering the public interest in encouraging the most qualified and able people to serve as officials of state and local governments. The potential damage liability for decisions made in good faith, it has been argued, could deter at least some such individuals from seeking positions of public responsibility. ${ }^{182}$ One response to this argument, of course, would be to suggest that there is no reason to expect that employment by government will generally subject a person to greater risks of lawsuits and recoveries than would similar employment in the private sector. To the extent that this is true, however, the good faith defense remains justifiable because it makes public employment that much more attractive than other opportunities and thus can serve as a means of furthering the public interest in an optimal force of government officials. A more basic problem with this argument is that it necessarily rests on the premise that the willingness of any individual to accept a particular position is affected by an evaluation of possible litigation and damage recoveries. Certainly, this might seem likely if the individual felt powerless to avoid frequent suits or recurring awards. But given that current standards require not simply fault, as defined by tort law, but proof of some form of intent in order to recover damages against individuals, ${ }^{183}$ the likelihood that possible liability will influence the individual employment decision seems substantially reduced.

The second principal argument favoring good faith defenses

(2) Knowingly advance a claim or defense that is unwarranted under existing law, except that he may advance such claim or defense if it can be supported by good faith argument for an extension, modification, or reversal of existing law.

ABA Code of Professional Responsibility, DR 7-ro2 (A) (r)-(2) (I975).

${ }^{182}$ See Wood v. Strickland, 420 U.S. 308, 320 (1975) ("The most capable candidates for school board positions might be deterred from seeking office if heavy burdens upon their private resources from monetary liability were a likely prospect during their tenure."); id. at 33 I (Powell, J., concurring and dissenting) ("In view of today's decision significantly enhancing the possibility of personal liability, one must wonder whether qualified persons will continue in the desired numbers to volunteer for service in public education.").

${ }^{183}$ See pp. I205־9 supra. 
takes for granted that the individual does have some control of his possible liability for damages. Absent qualified immunity, according to this view, the public official may well exercise his discretion so as to avoid potential liability, thus directing his judgment away from the concerns which should govern his decisions. ${ }^{184}$ Stated in this stark fashion, the argument is a difficult one to justify. Whatever other concerns should shape a particular official's actions, certainly one of them should be the constitutional rights of individuals who will be affected by his actions. To criticize section 1983 liability because it leads decisionmakers to avoid the infringement of constitutional rights is to criticize one of the statute's raisons d'être. ${ }^{185}$ At a subtler level, though, there may be some merit to this argument, although only in a limited set of circumstances. Where it was not apparent that action would infringe any constitutional rights and where the action was clearly a necessary - or at least a reasonable - means of securing certain social goals within the purview of the official, the imposition of damage liability on the individual may in fact be inappropriate. Part of the reason is the fairness of the cost shifting involved; it is difficult to find the official truly "at fault," for while his intentional actions resulted in the constitutional deprivation, the fact that the right involved was unclear and that the action was taken to further goals for which he is publicly responsible undercuts any sense of "blameworthiness." ${ }^{186}$ Moreover, there is a danger that were liability to be imposed in this case, the decisionmaker would in the future be reluctant to take action which is necessary to accomplish public goals and which would ultimately not infringe individual constitutional rights. ${ }^{187}$ Such a result would hamper the ability of public officials adequately to serve state and local needs without any justification in terms of federal constitutional rights.

${ }^{184}$ The Court in Scheuer v. Rhodes, 416 U.S. 232 (1974), noted two "mutually dependent rationales" for official immunity:

(I) the injustice, particularly in the absence of bad faith, of subjecting to liability an officer who is required, by the legal obligations of his position, to exercise discretion; (2) the danger that the threat of such liability would deter willingness to execute his office with the decisiveness and the judgment required by the public good.

Id. at 240 (citing Jaffe, Suits Against Governments and Officers: Damage Actions,

77 Harv. L. Rev. 209, 223 (1963)).

${ }^{185}$ See pp. I1 $54-55$ supra.

${ }^{186}$ See Gregoire v. Biddle, I77 F.2d 579, 581 (2d Cir. 1949) (L. Hand, J.) ("There must indeed be means of punishing public officials who have been truant to their duties; but that is quite another matter from exposing such as have been honestly mistaken to suit by anyone who has suffered from their errors."), cert. denied, 339 U.S. 949 (r950).

${ }^{187}$ See Scheuer v. Rhodes, 4 I6 U.S. 232, 242 (1974); Barr v. Matteo, 360 U.S. $564,572-73$ (1959). 
But if this is the rationale for good faith defenses, it is necessarily a limited one. Where constitutional rights are established with any clarity or where the individual official conduct in question is not reasonably designed to secure the goals of the defendant's office, this rationale cannot be invoked. In such cases, not only does the official appear "blameworthy," but the federal interest in the vindication of constitutional rights renders any rule which would encourage officials to err consciously and unnecessarily on the side of constitutional violations untenable. Nonetheless, it may well be the trend in the courts to expand, rather than to contract, the scope of the good faith defense by narrowly defining the category of clearly settled rights and by eliminating the objective test of the reasonableness of official conduct. ${ }^{188}$ To the extent that this is true, it will represent a substantial obstacle to the attempts of an individual to vindicate through a damage claim a deprivation of his constitutional rights - another obstacle which, like the others, is derived at least in part from the requirement that suits be brought against individuals. ${ }^{189}$

Indeed, the practical effect of the 1983 damage scheme is to render recovery unlikely even where the individual does not initially seem barred by one of the established doctrines. ${ }^{190}$ In what might be called the typical 1983 action, the plaintiff is likely to be a person who has been either charged with or convicted of a crime, or who displays other stigmas that tend to cast him in an unfavorable light in the eyes of a citizen who has never been drawn into confrontation with the established order - the most likely member of the jury. ${ }^{191}$ Moreover, the individual defendant in such an action is typically a low-level government official, such as a police officer, both because those officials are readily identi-

\footnotetext{
${ }^{188}$ See pp. I212-14 supra.

${ }^{189}$ See Note, supra note ${ }_{5} 6$, at 957 :
}

[T] he risk that imposing liability unqualified by an immunity or good faith defense upon municipalities would deter their officials from conscientiously executing their public duties seems much more attenuated than the risk attendant to imposing such liability upon the officials themselves. While it is possible that damage awards against municipalities might lead to administrative sanctions against the responsible officials, it seems likely that municipal administrators would refrain from imposing sanctions upon officials who appear to have been acting reasonably or in good faith.

${ }^{190}$ See Dellinger, Of Rights and Remedies: The Constitution As a Sword, 85 HARv. L. Rev. I532, I553-56 (I972) ; Kates \& Kouba, supra note 156, at 136-38; Note, supra note 156 , at $924 ; c f$. Bivens v. Six Unknown Named Agents of Federal Bureau of Narcotics, 456 F.2d r339 (2d Cir. 1972) (on remand) (holding good faith and a reasonable belief in the validity of warrantless search to be a defense in action for damages).

${ }^{191}$ Cf. Foote, Tort Remedies for Police Violations of Individual Rights, 39 Minn. L. REv. 493 (1955) (pointing out difficulties of recovering damages when claims brought as state torts). 
fiable as the immediate instruments of constitutional wrongs, and because court rulings on vicarious liability and immunities under section 1983 have made government entities and many higher ranking government officials unavailable as defendants in damage actions. ${ }^{192}$ These rank-and-file functionaries may well be sympathetic defendants in a jury's eyes for they are likely to be perceived as hard-working employees doing the best they can, who could ill afford to satisfy a hefty damage judgment. ${ }^{193}$ In those cases where upper-level state officials can be sued under section 1983, another set of circumstances conspires to make recovery improbable. Courts and juries share a measure of deference to governmental authority; the framework of good faith defenses applicable to high-level defendants permits courts to bend over backwards in instructing juries on the respect to be accorded an official's scope of discretion, ${ }^{104}$ and permits juries to do likewise in obeying those instructions. Finally, many 1983 plaintiffs are likely to face great difficulty in securing adequate recoveries because of problems of damage measurement. For example, it is difficult to place a monetary value on a given plaintiff's exercise of first amendment rights or his right to vote or to attend an integrated public school, or on his dignitary and symbolic interest in not being subjected to false imprisonment, invasion of privacy, or stigmatization as a result of unwarranted interferences by government law enforcement officials. ${ }^{195}$ While this difficulty of calculation has been ameliorated by the increasing recognition in both tort and section 1983 law that plaintiffs may recover for injury to so-called "dignitary interests," often in the guise of emotional stress, ${ }^{196}$ the law has not evolved to the point where it acknowledges an independent monetary value for constitutional rights per se. In addition, although punitive damages are generally available in the 1983 action, and indeed, have often been used to compensate plaintiffs where valuation of the right infringed would have been difficult, such damages are most often awarded only upon a showing that the defendant acted with malice. ${ }^{197}$

With avenues of relief closed off on all sides, or at least narrowed to mere alleys, 1983 damage actions have not been able to serve as an effective vehicle for securing either compensation or

${ }^{192}$ See pp. 1207-09 supra.

${ }^{193}$ See Foote, supra note 191 ; Note, supra note 156 , at 924.

${ }^{194}$ See Scheuer v. Rhodes, 416 U.S. 232 (1974); pp. 1209-17 supra.

${ }^{195}$ See Lewis v. Kugler, 446 F.2d r343 (3d Cir. r971); Lankford v. Gelston, 364 F.2d 197, 202 (4th Cir. I966) (en banc).

${ }^{196}$ See W. Prosser, supra note 141 , at $49-63$.

${ }^{197}$ See Palmer v. Hall, 517 F.2d 705 (5th Cir. 1975); Basista v. Weir, 340 F.2d 74 (3d Cir. 1965). 
deterrence. Since compensation is itself a valid end to be sought under the statute, this situation ought be rectified. ${ }^{198}$ But even an ideally functioning scheme of 1983 damage actions would, for a number of reasons, be insufficient to meet the needs of citizens whose constitutional rights are infringed or threatened by systemic violations committed by state or local governmental authority. ${ }^{199}$ First, if the plaintiffs are threatened with but have not yet been subjected to constitutional deprivations, an immediate award of damages would be inappropriate. Second, the damage recovery might well result in a double cost to the government: not only will damages for past violations be required, but if the damage judgment is to serve its desired purpose, it will result in the local government's also bearing the costs of remedial action to prevent future recurrences. If the particular government is unable simultaneously to bear both costs, constitutional rights may remain in jeopardy. Finally, a damage approach may be subject to the objection that it creates a situation in which the government is free, if it places a high value on certain types of unconstitutional conduct, to "purchase" the right to continue to inflict constitutional deprivations on its citizens. To meet violations of this order, then, a new kind of litigation seems critical.

\section{The Section 1983 Injunction Action: "Public Law" Adjudication}

The failure of the private damage action adequately to deal with systemic violations of constitutional rights has contributed to an increase in the frequency with which a new kind of 1983 suits is brought - suits fitting the description provided by Professor Abram Chayes for "public law" adjudication:

The party structure is sprawling and amorphous, subject to change over the course of the litigation. The traditional adversary relationship is suffused and intermixed with negotiating and mediating processes at every point. The judge is the dominant figure in organizing and guiding the case, and he draws for support not only on the parties and their counsel, but on a wide range of outsiders - masters, experts, and oversight personnel. Most important, the trial judge has increasingly become the creator and manager of complex forms of ongoing relief which have widespread effects on persons not before the court and require the judge's continuing involvement in administration and implementation. ${ }^{200}$

198 See pp. 1360-6r infra.

${ }^{199}$ See Lankford v. Gelston, 364 F.2d 197 (4th Cir. I966) (en banc).

${ }^{200}$ Chayes, The Role of the Judge in Public Law Litigation, 89 Harv. L. REv. I28I, I284 (1976). 
The shift embodied in such 1983 actions away from the individualized focus of the damage action to the broader pattern of systemic problems may be attributed to a number of factors. First, the decisions on supervisory liability establishing a distinction between individual acts of negligence and patterns of negligent conduct ${ }^{201}$ suggest not an individual constitutional right never to be injured at the hands of state officials but rather a right to live in a system which seeks to minimize such injuries. Under this logic, some injuries to citizens emerge as background costs of living in our society. We recognize, for example, that governments should not be required to install the most advanced computers in every police precinct in order to eliminate the possibility of innocent human error which may lead to false arrest. The significance of a pattern of injuries, as recognized at least in part by the courts, is to take the case out of the category of background costs: citizens may not have a constitutional right to be wholly free of injury at the hands of the state, but their claim is a different one when the responsible official fails to take any action in the face of a pattern of abuses which could efficiently be reduced. ${ }^{202}$

A second factor contributing to this shift is the development of modern procedures for multiparty litigation. ${ }^{203}$ In particular, the availability of class actions may lead people to begin looking at government action not as it affects the individual alone, but rather as it affects definable groups in the population. ${ }^{204} \mathrm{~A}$ third force may be the availability of systemic relief itself. Although it is difficult to isolate cause and effect, the willingness of courts to grant systemic relief is critical to the recognition of real systemic rights. ${ }^{205}$

${ }^{201}$ See pp. I $207-09$ supra.

${ }^{202}$ Under this logic, even a broad pattern of nonnegligent injuries might be sufficient to support liability because it would suggest a need for some action by responsible individuals to reduce the harms to citizens. Of course, to the extent that reasonable measures to accomplish this goal are available and the responsible officials have failed to take them, they might well be considered negligent. The point of this approach, however, is not so much to single out any particular official as "blameworthy" but rather to suggest those instances in which individuals have a legitimate claim against the government on account of the system which it perpetuates.

${ }^{203}$ See Chayes, supra note 200, at I289-90; Kaplan, Continuing Work of the Civil Committee: 1966 Amendments of the Federal Rules of Civil Procedure (pts. I \& 2), 8I HARv. L. REv. 356, 59I (1967, 1968); Shapiro, Some Thoughts on Intervention Before Courts, Agencies, and Arbitrators, 8I HaRv. L. REv. $72 \mathrm{I}$ (I968) ; Note, Intervention in Government Enforcement Actions, 89 HaRv. L. Rev. II 74 (1976).

${ }^{204}$ See generally Developments in the Law-Class Actions, 89 Harv. L. Rev. I318, 1353-73 (1976).

205 See id. at 1327 . 
While the issuance of broad structural relief in 1983 actions is a relatively modern phenomenon, the concern for breakdowns in state governmental systems is one that traces back to the Civil Rights Act of $187 \mathrm{I}$. It was not simply affirmative state action in support of the activity and conduct of the $\mathrm{Ku}$ Klux Klan that motivated the enactment of section 1983 in its original form but also the specter of state systems unwilling or unable to act in the face of massive violations of constitutional rights. ${ }^{206}$ The Court's suggestion in Rizzo v. Goode ${ }^{207}$ that a finding of liability is inappropriate when supervisory officials do not affirmatively implement an unconstitutional policy, ${ }^{208}$ however, has the potential to undermine section r 983 's effectiveness as a means of dealing with systemic breakdowns. ${ }^{209}$ Given the governmental immunity established by Monroe and City of Kenosha, ${ }^{210}$ system-wide injunctive relief, to be effective, must gnerally be directed at individuals at a high level of the governmental organization. A requirement of proof of deliberate and calculated infringement on the part of these officials may well be difficult to meet. But it is hard to see why this should matter. In the context of damage actions, proof of the individual's blameworthiness is relevant because of a concern for the effectiveness and fairness of imposing on him an obligation to pay damages to the plaintiff. ${ }^{211}$ Where the remedy sought is injunctive relief to prevent future deprivations or to undo the effects of past ones, however, the individual defendant is essentially a representative of the system. The real issue in such cases is the functioning of the system as a whole, not the actions of any particular official. ${ }^{212}$ Moreover, if personal fault were considered determinative, the legislative history of section I 983 as well as the "deliberate indifference" standard established in Estelle v. Gamble, ${ }^{213}$ which was decided after Rizzo, would seem to support a finding that a responsible official who ignores a pattern of injuries - even if only negligently inflicted and certainly if done intentionally - is himself fairly deemed "at fault."

Rizzo casts a further cloud on public law adjudication by its

${ }^{206}$ See pp. Ir $53-56$ supra.

${ }^{207} 423$ U.S. 362 (1976), noted in The Supreme Court, 1975 Term, 90 HaRv.

L. REv. 56, 238 (1976).

${ }^{208} 423$ U.S. at $375-77$.

${ }^{209}$ See Note, supra note 165 , at 532.

${ }^{210}$ See pp. I I $91-97$ supra.

${ }^{211}$ See pp. I $218-20$ supra.

212 According to this view, Rizzo should be read not to suggest an unwillingness to treat violations on a systematic basis but rather as resting "on the perceived absence of a showing that the district court's order was directed at practices that had caused violations in the first instance." Note, supra note 165 , at 532 .

21397 S. Ct. 285, 291 (1976). 
suggestion that the decree reversed in that case was an unwarranted interference by a federal court in the internal affairs of a local government. ${ }^{214}$ In reaching this conclusion, the Court invoked the language of comity and federalism of the Younger line of cases. ${ }^{215}$ Younger itself, however, barred only the enjoining by a federal court of an ongoing state criminal prosecution. ${ }^{216}$ In O'Shea v. Littleton, ${ }^{217}$ and several lower court cases, this bar has been held to extend to any relief that would impose "an ongoing federal audit" ${ }^{218}$ of state judicial proceedings. Thus, federal courts have declined to undertake a thorough reorganization of a state court system ${ }^{219}$ or state prosecutorial decisions $;{ }^{220}$ to order the assignment of particular counsel to indigent defendants; ${ }^{221}$ or to restructure the state system of imposing fines ${ }^{222}$ or setting bail. ${ }^{223}$ Never before Rizzo, however, was the Younger line invoked to bar relief that would have little or no impact on the state's judicial processes, but only on its executive functions. $^{224}$

It is one thing to recognize, as the Court in Rizzo did, that any time a court seeks to intervene in the affairs of a coordinate branch of government, problems of judicial competence are raised; it is quite a different matter to hold that whenever the other branch is a branch of the state government, the federal court must utterly stay its hand. Rizzo did not go this far, but to the extent that it set off down this road, it looms large as a threat to the viability of major 1983 injunction actions.

While it is still too early to assess the actual impact of Rizzo v. Goode on the public law model of section 1983 , it is clear that the validity of this new style of litigation under the statute must be reevaluated. The questions raised by this examination are concerned with the competence of the federal courts - as courts

\footnotetext{
${ }^{214} \mathrm{See}_{423}$ U.S. at $379-80$.

${ }^{215}$ Id. See generally Part VI, pp. $1274-1330$ infra.

${ }^{216}$ See Younger v. Harris, 40I U.S. 37 (1971).

${ }^{217} 4$ I4 U.S. 488 (1974).

$218 I d$. at 500 .

219 See Ad Hoc Comm. on Judicial Administration v. Massachusetts, 488 F.2d I24I (Ist Cir. I973).

${ }^{220}$ See Inmates of Attica Correctional Facility v. Rockefeller, 477 F.2d 375 (2d Cir. I975).

${ }^{221}$ See Bedrosian v. Mintz, 5 I 8 F.2d 396 (2d Cir. 1975).

${ }^{222}$ Karr v. Blay, $4{ }_{13}$ F. Supp. 579 (N.D. Ohio 1976).

${ }^{223}$ See Wallace v. Kern, 520 F.2d 400 (2d Cir. 1975).

${ }^{224}$ In the only case cited by Justice Rehnquist for this application, Mayor of Philadelphia v. Educational Equality League, 415 U.S. 605 (1974), the Court did not reach the issue; it recognized that there were "delicate issues of federal-state relationships," id. at $6 \mathrm{r}_{5}$, but also noted the "special regard of the Fourteenth Amendment for federal protection of federal rights," id.
} 
and as instrumentalities of the federal government - to deal with complex issues of organization, planning, and funding of functions ordinarily performed by state governments, usually through their executive branches. To give substance to this analysis, it is useful to consider the questions involved in light of two examples of major public law litigation brought under section 1983 .

I. Paradigm Cases. - (a) Reforming the Prisons: Rhem v. Malcolm. - In this case, ${ }^{225}$ in $197 \mathrm{I}$, inmates at the Manhattan House of Detention for Men ("the Tombs"), a New York City detention facility primarily housing pretrial detainees, brought a section 1983 class action challenging the conditions under which they were confined. ${ }^{226}$ Just before and just after the inception of the lawsuit there were disturbances at the facility, during which prisoners protested both conditions at the Tombs and the lengthy delays incurred before obtaining trial dates in the New York City criminal courts. Considerable property damage resulted, giving rise to tightened security measures. ${ }^{227}$ Following the disturbances, the Rhem plaintiffs sought a preliminary injunction to restrain prison authorities from continuing to permit the existence of allegedly unconstitutional conditions at the Tombs. ${ }^{228}$

The district court denied a motion to dismiss the action, and, without a hearing, granted in part plaintiffs' request for a preliminary injunction. ${ }^{229}$ The court found that while overcrowding and trial delay had "led to severe discomfort and distress among the inmates" even prior to the disturbances, the disturbances themselves had led to both tightened security and, through extensive property damage, the inability of the city to provide the services which the inmates lacked. ${ }^{230}$ Because the conditions were not "imposed, or ... permitted to continue as standing

${ }^{225}$ Rhem v. McGrath, 326 F. Supp. 68I (S.D.N.Y. 1971) (preliminary injunction); Rhem v. Malcolm, 37I F. Supp. 594 (S.D.N.Y. 1974) (opinion after trial); 377 F. Supp. 995 (S.D.N.Y.) (memorandum and order), aff'd and remanded, 507 F.2d 333 (2d Cir. 1974); 389 F. Supp. 964 (S.D.N.Y. 1975) (opinion on remand); 356 F. Supp. Ir95 (S.D.N.Y.) (opinion on plaintiffs' motion for amended relief), aff'd per curiam, 527 F.2d 104I (2d Cir. 1975).

${ }^{226}$ Rhem v. McGrath, 326 F. Supp. 68I, 682 (S.D.N.Y. I97I).

${ }^{227}$ Id. at $683-88$.

${ }^{228}$ Id. Plaintiffs' complaint raised a general due process claim which rested on the assertion that, as pretrial detainees, their confinement was permissible only under the "least restrictive" conditions. Rhem v. Malcolm, 37I F. Supp. 594, 600 (S.D.N.Y. 1974). Their equal protection claim asserted that as a class, they were confined under conditions of greater security and oppression than convicted felons elsewhere in the state. Id.

${ }^{229}$ Rhem v. McGrath, 326 F. Supp. 68I (S.D.N.Y. I97I) (Mansfield, J.).

${ }^{230} I d$. at $683-88$. 
policy, by an indifferent, neglectful, or vengeful prison administration," and because prison officials were "making good faith efforts" to improve them, the court could not find that conditions, however unsatisfactory, had descended "to a level proscribed by the Eighth Amendment." ${ }^{231}$ A preliminary injunction was issued against interference with private consultation between inmates and their attorneys, ${ }^{232}$ and defendants were ordered to promulgate a complete set of prison rules to be made available to all inmates after input from plaintiffs and court approval. ${ }^{233}$

The parties next conducted extensive negotiations, culminating in a consent decree concerning overcrowding, unsanitary conditions, and medical care ${ }^{234}$ a trial was held on several remaining issues, including lock-ins, visiting conditions, noise, ventilation and heat problems, recreational activities, and correspondence. $^{235}$ During the trial, the court heard testimony from inmates and expert witnesses in penology and prison administration, and toured the Tombs. ${ }^{236}$ In a lengthy opinion detailing numerous factual findings and drawing extensively on the expert testimony, Judge Lasker found that conditions at the Tombs violated the prisoners' due process rights; ${ }^{237}$ as a result, the defendants would be obligated to: ( I) eliminate all vestiges of maximum security not necessary for the safety of the prison or for assuring inmate presence at trial; ${ }^{238}$ (2) introduce a program of contact visitation; (3) provide for reasonable physical recreation; (4) provide a tolerable living environment at the prison; (5) provide adequate staffing; (6) grant additional procedural rights to prisoners in disciplinary proceedings; and (7) greatly reduce in-

231 Id. at 689.

${ }^{232}$ Id. at $690-9 \mathrm{I}$. The court noted that neither mail censorship nor summary discipline was claimed by defendants as "necessitated by the inmate disruptions"; it nonetheless upheld incoming mail inspection as a justified means to search for contraband except in the case of letters from attorneys, which could not be opened unless defendants provided another means for attorney-client consultation. Id.

${ }^{233} I d$. at $69 \mathrm{I}-92$.

${ }^{234}$ Rhem v. Malcolm, 37 I F. Supp. 594, 597 (S.D.N.Y. 1974). The city was apparently motivated to settle by the fact that a liberal judge had been assigned to the case and by the widespread publicity the case was receiving. See M. Hermann, Rhem v. Malcolm - A Case Study of Public Interest Litigation: Pretrial Detention I7-I9 (May 1977) (unpublished manuscript on file at the Harvard Law School library).

235 Rhem v. Malcolm, 37 I F. Supp. 594, 600-20 (S.D.N.Y. 1974).

${ }^{236}$ Id. at $597-98$.

237 Id. at 622 .

${ }^{238} I d$. at 624 . In this regard, Judge Lasker noted that it was well within the expertise of the defendants to develop a classification system separating those detainees needing maximum security from those who could be confined under less restrictive conditions. Id. 
spection of incoming prisoner mail. ${ }^{239}$ The court concluded by instructing the parties to prepare for a conference to determine the contents of a final order. ${ }^{240}$

Even prior to this opinion, there had been indications of less than enthusiastic compliance by the city with the earlier consent decree. The court had held several hearings on compliance, visited the Tombs, and ordered the city to submit a compliance status report, which was finally filed two months late. ${ }^{241}$ As conferences on the final order commenced, the city proved no more cooperative. Plaintiffs proposed a judgment requiring the defendants to "submit [within thirty days] a comprehensive and detailed plan for elimination of the [unconstitutional] conditions," and requested immediate final judgment on the issues which required little or no physical rearrangement at the Tombs, or expenditure of funds. ${ }^{242} \mathrm{~A}$ month later, the city proposed a counterorder which "failed to deal with the critical issues which required money and planning." ${ }^{243}$ The court then ordered the city to respond to plaintiffs' proposals, including any reasons why it was unable to conform to the court's opinion and any suggestions for alternatives. ${ }^{244}$ The city responded with a memorandum which failed to include a comprehensive plan, and requested additional time to prepare one. ${ }^{245}$

Finally, the court entered an order setting forth specific provisions with regard to prison discipline and inmate correspondence, scheduled further hearings, and ordered the city to present a comprehensive plan for eliminating all unconstitutional conditions at the Tombs. ${ }^{246}$ The city's much belated plan, when filed, was deficient in several respects; moreover, the city for the first time informed the court that it was "exploring the possibility of closing" the Tombs, though no date was specified. ${ }^{247}$ The city responded to further demands for specific plans with a "shopping list" it had submitted to the City Bureau of the Budget, indicating that funding had been approved for some improvements required by the consent decree, but not for several of those covered in the court's opinion. ${ }^{248}$ Though it decided to continue operating the Tombs, the city declined to report on

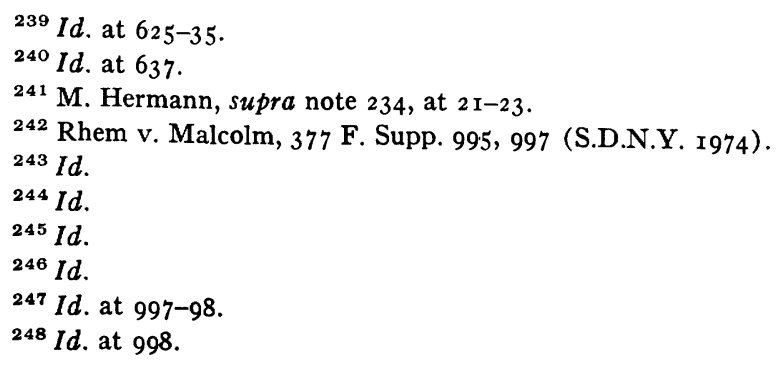


compliance, informing the court that the cost of improving physical facilities was "far in excess of what is available under the City's present budget . . . ."249

The court responded by ordering the Tombs closed within thirty days, its order subject to reconsideration should the city submit a "comprehensive, detailed and specific plan" for the prompt elimination of unconstitutional conditions. ${ }^{250}$ While the court sympathized with the city's budgetary problems, it noted that "the law does not permit any government to deprive its citizens of constitutional rights on a plea of poverty . . . . [E]xpenditures not required by the Constitution may not be given priority over those needed to remedy a deprivation of constitutional rights." 251 The Second Circuit affirmed Judge Lasker's findings on the merits, ${ }^{252}$ and ruled that on remand a decree

should be framed to close the prison to detainees or to limit its use for detainees to certain narrow functions by a fixed date, unless specified standards are met ... . Once the appropriate standards or permissible limited uses are established, the court can . . . determine whether there has been compliance by the .. . deadline. ${ }^{253}$

One week after the Second Circuit decision, the city decided to close the Tombs and transfer the Rhem plaintiffs to the House of Detention for Men on Riker's Island (Rikers). While the city argued that this action rendered the lawsuit moot, the plaintiffs claimed to be entitled to the same relief granted earlier, except on issues specifically related to the Tombs' physical plant. ${ }^{254}$

Judge Lasker, after visiting Rikers and holding extensive hearings, ruled that the plaintiffs were entitled to continue their action, but modified in some respects the specific relief granted in the Tombs context to reflect different conditions unique to Rikers. ${ }^{255}$ Plaintiffs' motion for additional relief was denied; the court

${ }^{249}$ Id. at 998, 1003.

${ }^{250}$ Id. at $999-1000$.

251 Id. at 999.

${ }^{252}$ Rhem v. Malcolm, 507 F.2d 333, 336-39 (2d Cir. 1974).

${ }^{253}$ Id. at 340 . The court noted that in a situation, unlike this one, where a "closing" alternative was not viable, a district court "might have no choice but to order an expensive, burdensome or administratively inconvenient remedy." Id. at 34 I n.I9 (citing Swann v. Charlotte-Mecklenburg Bd. of Educ., 402 U.S. I, 28-30 (I97I) ; Goss v. Board of Educ., 482 F.2d 1044, 1046 (6th Cir. 1973) (en banc), cert. denied, 4 I4 U.S. II I ( I974)).

${ }^{254}$ Rhem v. Malcolm, 389 F. Supp. 964,966 (S.D.N.Y. I 975 ).

${ }^{255} I d$. at $966-72$. The court also declined to grant plaintiffs daily telephone access, the right to meet counsel and receive personal visits in New York County, and the right to be housed overnight in order to consult with counsel or appear 
ruled that the issues at Rikers raised questions more suitable to a new plenary action than to a case on remand after a final judgment. ${ }^{256}$ The city then commenced an appeal from the relief that the court had ordered in its most recent Rhem decisions. ${ }^{257}$ And when Judge Lasker granted the plaintiffs' motion in their new action, Benjamin v. Malcolm, ${ }^{258}$ for a preliminary injunction extending Rhem's relief to all inmates at Rikers, that order was also appealed. Both orders were affirmed by the Second Circuit. ${ }^{259}$ The panel rejected the city's assertion that the district court action represented an unwarranted interference with prison administration:

We are not unaware of the financial difficulties presently confronting the city defendants. But the need to bear this particular financial burden hardly comes as a surprise to the penal authorities, who have been fighting losing battles in this litigation for almost five years. More importantly, an individual's constitutional rights may not be sacrificed on the ground that the city has other and more pressing priorities. ${ }^{260}$

By the time of the Second Circuit's final decision in Rhem v. Malcolm, ${ }^{261}$ conditions in the New York City prison system were again in a state of crisis. Other litigation had resulted in orders aimed at unconstitutional conditions at the Brooklyn and Queens detention facilities, with the practice of "double celling" detainees ruled impermissible; ${ }^{262}$ at the same time, the city's fiscal crisis had forced reduction in prison staff and the closing of several other detention facilities. ${ }^{263}$ Finally, the city moved in

in court, all of which would have placed the transferred inmates in a position close to the status quo they enjoyed at the Tombs. Id. at 970. The court sympathized with the plaintiffs, but as this requested relief had never formed a part of the original Tombs litigation, it felt itself barred from granting it. Id. at 969-70; see Rhem v. Malcolm, 396 F. Supp. II95, II $196-1203$ (S.D.N.Y. 1975) (amended relief).

${ }^{256}$ Rhem v. Malcolm, 396 F. Supp. I 195, I203-04 (S.D.N.Y. I975).

${ }^{257}$ Rhem v. Malcolm, 389. F. Supp. 964 (S.D.N.Y. I975) ; 396 F. Supp. II 95 (S.D.N.Y. I975).

${ }^{258}$ Benjamin v. Malcolm, No. 75 Civ. 3073 (S.D.N.Y. July I4, I975).

${ }^{259}$ Rhem v. Malcolm, 527 F.2d I04I (2d Cir. I975) (per curiam).

${ }^{260}$ Id. at 1043-44 (citations omitted).

${ }^{261}$ See id.

${ }^{262}$ Detainees of the Brooklyn House of Detention v. Malcolm, 520 F.2d 392 (2d Cir. 1975) (Brooklyn and Queens detention facilities). When Judge Lasker inco-porated Judge Judd's order prohibiting double celling into the Benjamin litigation, see Benjamin v. Malcolm, No. 75 Civ. 3073 (S.D.N.Y. Nov. 18, 1975), the city was unable to play "musical jails" by transferring detainees to facilities not covered by court injunctions, since all its facilities were now under court orders. See M. Hermann, supra note 234 , at 34-40.

${ }^{263} \mathrm{M}$. Hermann, supra note 234 , at $34-40$. 
Rhem for leave to reopen the Tombs, without being required to comply with the consent decree of 1973 or Judge Lasker's orders. ${ }^{264}$ Thus, at the close of six years of litigation in Rhem, detention facilities remain largely in an unconstitutional condition.

(b) Desegregating the Schools: Morgan v. Kerrigan. ${ }^{265}$ - In r974, black students and parents filed a section I 983 class action seeking desegregation of the Boston school system. ${ }^{266}$ Judge $W$. Arthur Garrity, after a lengthy trial, issued a detailed opinion finding that Boston school officials had perpetuated a segregated school system by their decisions in such matters as use of existing school facilities and new construction, districting, school feeder patterns, and assignment of faculty. ${ }^{267}$ While the district court made the formulation of a comprehensive remedial plan the responsibility of school authorities, subject to court approval, it set forth general guidelines concerning the appropriate remedy ${ }^{268}$

${ }^{264}$ See id. at 39.

${ }^{265}$ Morgan v. Hennigan, 379 F. Supp. 4 Io (D. Mass.), aff'd sub nom. Morgan v. Kerrigan, 509 F.2d 580 (Ist Cir. I974), cert. denied, 42 I U.S. 963 (I975), enforced by 40I F. Supp. 216 (D. Mass.), aff'd, 523 F.2d 9I7; 530 F.2d 40I; 530 F.2d 43 I (Ist Cir. I975), cert. denied, 426 U.S. 935 (1976), enforced by 409 F. Supp. II4I (D. Mass. I975), aff'd sub nom. Morgan v. McDonough, 540 F.2d 527 (Ist Cir. I976) (appointment of receiver).

${ }^{266}$ Morgan v. Hennigan, 379 F. Supp. 410 (D. Mass. 1974). Prior to the instigation of the federal lawsuit, the Boston school system had been the target of desegregation efforts on the part of both Massachusetts educational authorities and the federal government. Under the Massachusetts Racial Imbalance Act, Mass. Gen. Laws ANN. ch. 7I, §§ 37C-37D (West I969); id. ch. I5, §§ II-I K, commanding affirmative action to achieve racial balance in public schools whether the cause of imbalance was de jure or de facto, but limiting busing as a remedy to situations where there is parental consent, the Massachusetts State Board of Education had consistently attempted, with the use of the state courts, to force the Boston School Committee to eliminate segregation in the city schools. See Morgan v. Hennigan, 379 F. Supp. at 4I 7-20; School Comm. v. Board of Educ., 363 Mass. 20, 292 N.E.2d 338; 363 Mass. I25, 292 N.E.2d 870; 364 Mass. I99, 302 N.E.2d 9I6 (I973). The state action, which was accompanied by persistent intransigence by Boston school officials, 379 F. Supp. at $418-20$, resulted in the promulgation of a desegregation plan which became "Phase I" of the eventual federal court desegregation effort, see Morgan v. Kerrigan, 40I F. Supp. 216,225 (D. Mass. I975), but which did not moot the federal action because the obligations incurred by the Boston School Committee under state law were not coterminous with those required under the Federal Constitution. See 379 F. Supp. at $420 ; 401$ F. Supp. at 224 .

In addition, under the Civil Rights Act of $1964, \S 602,42$ U.S.C. $\S 2000 d-I$ (1970), the federal government secured a cutoff of substantial funding to the Boston school system, which was found to have been marked by de jure segregation. See 379 F. Supp. at $420-21$.

${ }^{267}$ Morgan v. Hennigan, 379 F. Supp. 410, 425-77 (D. Mass. I974).

${ }^{268} \mathrm{Id}$. at $482-84$. The guidelines included the observation that the defendants had an affirmative obligation to remedy the constitutional violations; that while primary responsibility for remedy rested with the defendants, their actions were 
and ordered immediate compliance with a partial integration plan ordered by the Massachusetts courts in an earlier suit (Phase I) ${ }^{269}$ The court of appeals affirmed, noting that while implementation of the required remedy would doubtless cause trauma, a constructive solution ultimately "depends . . . upon 'the fruitful exercise of the responsibilities of those charged with political official power.' " 270

Following the affirmance, the city defendants requested time to promulgate an alternative plan to the one imposed by the state courts, but were unable to submit one. ${ }^{271}$ The district court's attention turned to implementation of Phase I of the desegregation order, which was marred by violence and severe community opposition at several schools. ${ }^{272}$ In response, the court, with the participation of the parties, established "racial-ethnic councils" of students and parents to aid in calming the atmosphere; at one particularly troublesome school, state and local police were utilized to maintain order, and a monitoring program developed by the United States Department of Justice placed volunteers in the building to assist the effort. ${ }^{273}$ In the meantime, the court held numerous hearings and issued additional guidelines for the formulation of Phase II of the desegregation program, strongly hinting that some busing might be required to achieve desegregation. ${ }^{274}$ When the school committee voted $3^{-2}$ not to submit a plan that its legal staff had already prepared, the staff filed the plan on its own, and then resigned. ${ }^{275}$ Plaintiffs moved to have the majority on the committee held in contempt; in response to court questioning, the officials indicated that they would obey court orders but would take no other action except to ensure the safety of students and to implement the state plan. ${ }^{276}$ The court held the officials in civil contempt; they purged themselves by submitting a new plan which provided for no forced busing. ${ }^{277}$ All parties were given an opportunity to comment on and suggest alternatives to the proposals of the school officials and the plaintiffs. ${ }^{278}$ The court also received extensive input from local

to be judged by their effectiveness, and that even techniques, such as busing, personally offensive to defendants might well be required. Id. at 482 .

${ }^{269}$ Id. at 483 .

${ }^{270}$ Morgan v. Kerrigan, 509 F.2d 580, 598 (Ist Cir. 1974), cert. denied, $42 \mathrm{I}$ U.S. 963 (r975).

${ }^{271} 4$ OI F. Supp. at 224 .

272 Id. at 224-25.

${ }^{273} I d$.

${ }^{274}$ Id . at 225.

${ }^{275}$ Id. at 226.

${ }^{276} I d$.

${ }^{277} I d$.

${ }^{278} I d$. at 226-27. 
and state government officials, the teachers' union, and several community groups, and groups representing Hispanic students and white Boston homeowners were permitted to intervene. ${ }^{279}$

Because of what it termed "the complexity and multiplicity of the .. . plans and proposals filed," the court appointed a panel of masters, along with several experts to assist them, to hold evidentiary hearings and advise the court. ${ }^{280}$ The masters' desegregation plan, which was the subject of additional hearings and comment, was finally adopted by the court, which rejected the defendants' plan as "not promis[ing] realistically to desegregate the public schools." 281 The Phase II plan was a comprehensive one, providing for, among other things, redistricting, reassignment of students, busing, contracting with local colleges, special educational programs, and hiring of additional supervisory personnel. ${ }^{282}$ Integral to the plan was the court's realization that any effective remedy required not only numerical redistribution of students, but the guarantee of an equal educational opportunity for all students, particularly those harmed by the effects of past discrimination. ${ }^{283}$ While primary reliance for the remedy and a successful transition was placed on school personnel, the court, with the support of most of the parties, established a Citywide Coordinating Council to monitor compliance and advise the school committee and court on continuing progress. ${ }^{284}$ In addition, all parties consented to the establishment of District Advisory Councils to provide for citizen participation and input. $^{285}$ Over school committee objections that the plan represented an encroachment on the educational authority of local officials, ${ }^{286}$ the First Circuit affirmed, holding that while "[i]deally . . . the school committee would be the favored source for a plan," 287 "[the] overriding fact of the matter is that the district court . . . has had to deal with an intransigent and obstructionist School Committee . . . engaged in a pattern of resistance, defiance and delay. . . . [T]his crucial fact justifies . . . a number of extraordinary measures which might otherwise be open to question." 288 The plan went into operation beginning with the r975-r976 school year.

\footnotetext{
279 Id.

$280 I d$. at 227.

${ }^{281}$ Id. at $228-29$.

282 Id. at $250-70$.

${ }^{283} \mathrm{Id}$. at $23 \mathrm{I}-35$.

${ }^{284}$ Id. at $234-35,248-49$.

${ }^{285} I d$. at $248-49$.

${ }^{286}$ Morgan v. Kerrigan, 530 F.2d 40I, 427 (Ist Cir. 1976).

${ }^{287}$ Morgan v. Kerrigan, 523 F.2d 917, 922 (Ist Cir. 1975).

${ }^{288}$ Morgan v. Kerrigan, 530 F.2d 401, 427 (Ist Cir. I976).
} 
In November 1975, plaintiffs petitioned the district court to close South Boston High School, a scene of much trouble during Phase $I,{ }^{289}$ on the grounds that black students there were being denied their right to peaceful, integrated, nondiscriminatory education..$^{290}$ After hearing extensive testimony and visiting the high school, ${ }^{291}$ Judge Garrity ordered that the high school be placed under a federal court receivership and appointed the local district superintendent as receiver ${ }^{292}$ so that the "interventions would least interfere with the normal operations of the school." ${ }^{293}$

Restating the now traditional "public law" wisdom that once a constitutional violation is found, the federal court's equitable powers are broad, the First Circuit, with words of caution, approved Judge Garrity's most intrusive step into local school operation. ${ }^{294}$ The court reasoned that if the school committee had evinced a willingness to cooperate, either a voluntary approach or resort to contempt proceedings or additional injunctive relief might well have been viable alternatives, but because of the committee's "resistance and subterfuge," the district court had no real choice. ${ }^{295}$

This litigation is clearly not over. Though conditions in South Boston are better now than they have been since suit was brought, Judge Garrity is still actively involved in the Boston school system, and the likelihood of further confrontations is far from remote. ${ }^{296}$

\footnotetext{
${ }^{289}$ Morgan v. McDonough, 540 F.2d 527, 529 (Ist Cir. 1976), aff'g Morgan v.

Kerrigan, 409 F. Supp. I14I (D. Mass. 1975). See p. I 237 supra.

${ }^{290}$ Morgan v. McDonough, 540 F.2d 527, 529 (Ist Cir. 1976).

291409 F. Supp. at $1142-47$.

${ }^{292}$ Morgan v. Kerrigan, 409 F. Supp. II4I (D. Mass. I975), aff'd sub nom. Morgan v. McDonough, 540 F.2d 527, 530-33 (Ist Cir. 1976). The receiver was later changed. $540 \mathrm{~F} .2 \mathrm{~d}$ at 529 .

${ }^{293} 409$ F. Supp. at II5I. Some teaching staff and the headmaster of the school were ordered transferred. Id. at II50-5I. The court found that all administrative personnel at the school were white; that student handbooks - mailed to all parents and students - praised the most prominent Boston antibusing organization and ignored the presence of black students altogether; that black students had been intimidated, subjected to racial epithets, and then disciplined for acting in self-defense; that the white students consistently chanted, " $2,4,6,8$, assassinate the nigger apes," requested that music be played continually over the school's public address system to "soothe the savage beasts," and were not subject to any form of discipline. See id. at Ir 43-48; Morgan v. McDonough, 540 F.2d 527 , 530-32 (Ist Cir. I976).

${ }^{294}$ Morgan v. McDonough, 540 F.2d 527, 533-35 (Ist Cir. 1976). See generally Roberts, The Extent of Federal Judicial Equitable Power: Receivership of South Boston High School, in New England L. Rev. 55 (I976).

${ }^{295}$ Morgan v. McDonough, 540 F.2d 527, 533-34 (Ist Cir. 1976).

${ }^{296}$ More recently, Judge Garrity issued several orders concerning Phase III of the desegregation effort which included provisions for the busing of some kindergarten students; some additional busing of other students; and a blueprint
} 
2. The Legitimacy of Systemic Relief. - The preceding cases suggest the substantial problems involved in judicial attempts to reform and reorder major governmental programs and institutions. The existence of such difficulties gives rise to the need for careful evaluation of the competency of the judiciary to undertake these tasks. Before doing so, however, it is important to distinguish the problems which legitimately implicate concerns for the competency and legitimacy of judicial action from those with which they are easily confused but which do not call into question the role of the courts.

First, there is the question of the constitutional norm itself the question of when the state has violated an individual's right. The Bill of Rights is an antimajoritarian creed, imposing limits on what the majority, through its elected representatives, leaders, and officials, may do to any individual. ${ }^{297}$ That certain judicially imposed limits on the popular will provoke popular outbursts of indignation should not be surprising; indeed, it is the recognition of this attitude that supports entrusting to a body largely isolated from majoritarian pressures - the judiciary - the role of interpreting the mandates of the Constitution. ${ }^{298}$ One might agree or disagree with judicial pronouncements as to the scope of constitutional rights, but our tradition leaves no room for the argument that the articulation of constitutional norms is not the appropriate province of the judiciary. ${ }^{299}$

Second, there is the related question of change. Attempts to reform major institutions or programs - whether inspired by judicial order or otherwise ${ }^{300}$ - may create controversies and

for ending federal court involvement in the Boston schools, under which a "Permanent Department of Implementation" would "assume responsibility for all aspects of the court's desegregation plan . . . and the authority to carry it out." Boston Globe, May 9, I977, at I, col. 5. In issuing the orders, Judge Garrity noted that "the court must be mindful . . . that the present School Committee, ... like its predecessor committees . . . refuses to assume its constitutional obligation to act affirmatively to implement and sustain desegregated education in the city of Boston." Id. at I, col. 3. The court also recently denied a request to lift the federal receivership of South Boston High School, but specified several conditions which, if met by the Boston School Committee, could lead to the end of federal court control of the school. Boston Globe, May 10, 1977, at 7, col. I. The School Committee has indicated that it will appeal at least that part of the Phase III order establishing the implementation department. Id.

${ }^{297}$ See generally A. Cox, The Role of the Supreme Court in American GovernMent 31-56 (1976).

${ }^{298}$ See, e.g., Neuborne, The Myth of Parity, 90 HaRv. L. Rev. I105, II27-28 (1977).

${ }^{299}$ See, e.g., United States v. Nixon, 418 U.S. 683, 704-05 (1974); Marbury v. Madison, 5 U.S. (I Cranch) I37 (I803).

${ }^{300}$ Indeed, any efforts to reform existing institutions or to introduce new social programs, whether by the executive, legislative, or judicial branch of gov- 
tensions as those attached to the status quo are forced to readjust to a new order. And the fact that change is judicially ordered suggests that at least to some extent, it is in opposition to the popular or governing will, which in turn may enhance opposition. ${ }^{301}$ The finding of a constitutional violation, however, renders inapposite any argument that change should not be favored and that a positive normative value should attach to the status quo. The real issue, then, is not whether desegregation of the Boston schools or improvement of the Tombs in New York is a proper goal; rather, it is whether the judiciary can and should direct school desegregation or prison improvement. If the answer is yes, then standards and procedures must be developed which can guide their efforts; if it is no, then we face the untenable prospect of rights for which there are no remedies.

The question whether courts can shape relief in public law cases involves, initially, a question of expertise. ${ }^{302}$ While constitutional adjudication in public law litigation never mandates the establishment of ideal prison or school systems, it does require - if the case is to be considered justiciable ${ }^{303}$ - that the courts set minimal standards for government action in these and other areas with which judges may well be unfamiliar. ${ }^{304}$ The lack of personal expertise, however, need not prove an insuperable obstacle. In many areas, minimal standards passing constitutional muster will have already been set by the state legislature ${ }^{305}$ thus

ernment, is bound to be attended by serious implementation problems, with the goal achieved likely to fall short of the aspirations and expectations of those programs instituting the change. See generally J. Pressman \& A. Wildavsky, ImPLEMENTATION 73-74, 87-9I, 107-09 (1973). Thus criticism of public law litigation solely on grounds that the ultimate goals reflected in the decrees are not fully realized is overdrawn.

${ }^{301}$ See generally Neuborne, supra note 298 , at I I 28.

302 See D. Horowitz, The Courts and Social Policy i 7-ig. (1977).

${ }^{303}$ See Baker v. Carr, 369 U.S. I86 (1962).

${ }^{304}$ For example, in Wyatt v. Stickney, 344 F. Supp. $373 ; 344$ F. Supp. 387 (M.D. Ala. 1972), enforcing 334 F. Supp. I34I (M.D. Ala. 1971), aff'd in part, remanded in part, decision reserved in part sub nom. Wyatt v. Aderholt, 503 F.2d I305 (5th Cir. 1974), the district court was required to formulate minimum "medical and Constitutional" standards of treatments for civilly committed mental patients. 334 F. Supp. at 376; see Case Comment, Wyatt v. Stickney and the Right of Civilly Committed Mental Patients to Adequate Treatment, 86 Harv. L. REv. I282 (1973).

${ }^{305}$ In Estelle v. Gamble, 97 S. Ct. 285 (1976), for example, the Supreme Court, in holding that prisoners have a right to treatment for serious medical needs, relied on legislation in several states recognizing the states' obligation to provide medical care. See id. at 290-9I \& n.8. Moreover, even absent explicit and detailed legislative standards, legislation may reflect implicit policy choices from which courts can receive guidance in formulating manageable standards. See, e.g., Rodway v. U.S. Dep't of Agriculture, 5 I4 F.2d 809 (D.C. Cir. 1975). 
providing the courts with the requisite manageable standards for relief. Even where they have not, numerous competencyenhancing techniques exist which can provide the judge with enough information to arrive at adequate standards upon which to base a decree. ${ }^{306}$ For example, Judge Lasker in Rhem visited the Tombs personally ${ }^{307}$ and relied heavily on the testimony of experts in penology; ${ }^{308}$ Judge Garrity in Morgan sought input not only from educational experts but also from interested groups in the community as well as the parties themselves. ${ }^{309}$ Expanded discovery procedures facilitate the education of judges, and masters may be employed, as they were in Morgan, to work out details of complex remedial orders. ${ }^{310}$ Indeed, it is difficult to conceive of an area in which an inventive judge would be unable to draw on some existing reservoir of knowledge and experience in order to develop meaningful parameters for relief. ${ }^{311}$

A far more troublesome aspect of the justiciability question is whether, even given the existence of manageable standards, a court should act - whether a particular societal problem can be attacked only through legislative or executive processes. The question has on occasion been answered in a relatively simplistic fashion by a finding that a specific function is explicitly com-

${ }^{306}$ See Chayes, supra note 200 , at I299-1301; Note, The Wyatt Case: Implementation of Judicial Decree Ordering Institutional Change, 84 YALE L.J. I338 (1975); pp. I23I-39 supra.

${ }^{307} \mathrm{See}$ Rhem v. Malcolm, 37I F. Supp. 594, 597-98 (S.D.N.Y. 1974); p. 1232 supra

308 371 F. Supp. at 622.

${ }^{309}$ See Morgan v. Kerrigan, 40I F. Supp. 216, 226-27 (D. Mass. 1975); pp. I 237-38 supra.

${ }^{310}$ See Draft Report of the Masters, Morgan v. Kerrigan, Civ. No. 72-91 I-G (D. Mass. March 21, 1975); Chayes, supra note 200, at 1300-0I \& n.87.

${ }^{311}$ See Case Comment, supra note 304, at 1296-97. Even absent legislative standards to guide judicial formulation of relief, generalized minimum standards can often be derived sufficient to provide some relief for aggrieved citizens without requiring the courts to make complex technique judgments. For example, in Hawkins v. Town of Shaw, 303 F. Supp. 1162 (N.D. Miss. 1969), rev'd, 437 F.2d I286 (5th Cir. 1971), aff'd en banc, 46I F.2d II7I (5th Cir. 1972) black citizens of a small Mississippi town brought a $\$ 1983$ action alleging unconstitutional racial discrimination in the provision of municipal services as manifested in the substantial disparity between services provided in predominantly white and black areas of town. The district court had dismissed the action, largely on grounds that formulating relief would require judicial determination of standards for municipal services and financing - questions more properly left to local government decisionmakers. See 303 F. Supp. at $1167-69$. Reversing, the Fifth Circuit noted that while no statutory standards or regulations existed that defined what level of services a town like Shaw should provide, "the quality and quantity of ... services provided in the white areas of town" presented "a most reliable yardstick" for the court to use in establishing standards for relief. 437 F.2d at 1292. 
mitted to the legislature or executive. In prisoners' rights cases, for example, federal courts for many years refused to intervene at all in state prison operation, finding that the state legislature had delegated complete authority in that area to the discretion of the executive, and fearing that any intervention would impair the objectives of prison administration. ${ }^{312}$ And in Gilligan $v$. Morgan, the Supreme Court overturned a lower court's attempt to issue guidelines to the state of Ohio for the training and discipline of its National Guard, holding that "[t]he relief sought ... would ... embrace critical areas of responsibility vested by the Constitution in the Legislative and Executive Branches of Government." 313

Yet as the Court itself recognized in Gilligan, recent holdings in voting rights and prisoners' rights cases have demonstrated that a reflex application of "explicit commitment" doctrine may not be justified. ${ }^{314}$ To be sure, there are a number of factors which may render courts less desirable than other forums for the resolution of certain social problems. ${ }^{315}$ The most readily identifiable of such factors is that, unlike the courts, legislators and some executive officials are directly politically accountable to the electorate; they are therefore the institutions our democratic system of government grants the responsibility to determine the content and nature of government programs to address societal problems. ${ }^{316}$ A second set of factors stems from the fact that the proper remedy for systemic flaws is often bound up with social science issues that courts can grasp only with some difficulty. ${ }^{317}$ Legal facts - the facts with which courts are most accustomed to dealing - are immutable; they concern events that have already transpired. Social facts, on the other hand, represent patterns of behavior and render fluid the situations out

${ }^{312}$ See, e.g., McCloskey v. Maryland, 337 F.2d 72 (4th Cir. 1964); Hatfield v. Bailleux, 290 F.2d 632 (9th Cir.), cert. denied, 368 U.S. 862 (I96I). See generally Note, Constitutional Limitations on the Conditions of Pretrial Detention, 79 YALE L.J. 94I, 94I \& n.3 (1970); Note, Beyond the Ken of the Courts: A Critique of Judicial Refusal to Review the Complaints of Convicts, 72 YALE L.J. 506 (1963). More recently, of course, changing attitude towards the rights of prisoners has resulted in substantial judicial scrutiny of prison conditions and procedures. See, e.g., Estelle v. Gamble, 97 S. Ct. 285 (1976) ; Meachum v. Fano, 427 U.S. 215 (1976); Baxter v. Palmigiano, 425 U.S. 308 (1976); Wolff v. McDonald, 418 U.S. 539 (1974).

${ }^{313} 4$ I3 U.S. I, 7 (I973).

${ }^{314}$ Id. at II; see Haines v. Kerner, 404 U.S. 5 I9 (I972); Baker v. Carr, 369 U.S. I86 (1962). See generally Henkin, Is There a Political Question Doctrine?, 85 YALE L.J. 597 ( I976).

${ }^{315}$ See generally A. Cox, supra note 297 , at $99-118$.

${ }^{316}$ See D. HorowITz, supra note 302 , at $274-84$.

${ }^{317}$ Id. at 276 . 
of which they arise. The extent to which courts should take cognizance of social science evidence is far from clear; often, even when a court wishes to use such evidence in structuring detailed relief, it is not available in sufficiently reliable form. "These general problems indicate that the fit between law and social science is not a comfortable one, and will not be for some time. . . . Rarely does there seem to be a good mesh." ${ }^{318}$ Finally, the ability of a court even to attempt to reform a major societal system is dependent on what cases are brought before it; courts find it difficult to judge how representative an individual case may be, and it may often be the most egregious case that is deliberately made the subject of litigation:

No doubt there is something to be said, in terms of building public support, for making law from egregious cases. Controversial, innovative decisions are more easily justified when they spring from extreme circumstances. On the other hand, general law made from exceptional cases is not likely to be accorded much legitimacy by the knowledgeable bureaucrats and specialists who sense that the court was misled by unrepresentative cases. ${ }^{319}$

These arguments are all bottomed on the principle of separation of powers. But the doctrine of separation of powers has a reverse side as well, and that is the doctrine of checks and balances. It is certainly preferable to have the jails of New York run by New York City and its Department of Corrections and to have the schools of Boston controlled by the city of Boston and its school committee. But it remains the role of the courts to ensure that constitutional rights are not violated in the process. Where they are, the deference normally accorded the operations of the legislative and executive branch no longer is justified, and the court's function in a system of separated powers may require it to act affirmatively as a check on the responsible branches. To quote Judge Tuttle in Hawkins v. Town of Shaw, the principle of separation of powers "assumes that we have a system of checks and balances.... Utilizing the power vested in this court to check an abuse of state . . . power is, in effect, consistent with the principle." 320

Of course, the judiciary should not ignore the politically responsible parties or lose sight of its own limitations. Efforts should be made, through class certification procedures ${ }^{321}$ and

\footnotetext{
${ }^{318} I d$. at 267 .

${ }^{319}$ Hawkins v. Town of Shaw, 437 F.2d I 286, I292 (5th Cir. 1971). ${ }^{320} I d$.

${ }^{321}$ See Developments in the Law-Class Actions, supra note 204, at 147 I-94.
} 
sample notice, ${ }^{322}$ as well as through liberal grants of intervention, ${ }^{323}$ amici briefs, open hearings, citizen committees, and the like, to counteract any inherent tendency in the judicial process to yield a limited picture of a broad social problem. Similarly, the participation of the responsible political officials, no matter how culpable in the past, is critical both to the formulation of a reasonable and workable plan and to its implementation. The role of the judge in such cases, as Professor Chayes has pointed out, will often be to mediate between the parties as well as to direct their negotiations. ${ }^{324}$

To the extent that the determination of relief results from negotiations not only among the court, the defendant, and representative plaintiffs and their lawyers, but also among other interested and expert parties in the community, the process begins more and more to resemble the mutual interest accommodation which characterizes decisionmaking in the political arena. ${ }^{325}$ There is one crucial difference, however: the fact of a finding of a constitutional violation, bringing with it judicially determined minimal standards and the threat of a judicially imposed decree, greatly enhances the bargaining position of precisely those interests which were unsuccessful in influencing legislative or executive action in the first instance. That this difference is a product of the involvement of the judiciary may be seen as a novel yet wholly consistent application of Justice Stone's suggestion in the famous Carolene Products footnote that the judiciary should play a special role in protecting "discrete and insular minorities" who because of prejudice may be left unprotected by the political process. $^{326}$

Nonetheless, the need to transplant the political process into the judicial forum may be seen as evidence that the task of effecting change in societal institutions is one that should not be entrusted to the judiciary. Certainly, the formulation of relief will often take the court out of the role of the objective and neutral arbiter, and will involve choices which are neither specifically compelled by the finding of a violation nor controlled by any abstract logic. But this does not distinguish decisions on relief from other conclusions readily seen as "judicial" - conclusions as to the constitutionality of statutes and actions which necessarily involve the courts in value choices as to what is good or bad or right or

\footnotetext{
${ }^{322}$ See M. Hermann, supra note 234 , at $75-77$.

${ }^{323}$ See Note, supra note 203.

${ }^{324}$ See Chayes, supra note 200, at 1298-1301.

325 See C. Lindblom, The Intelligence of Democracy 3-17 (I965).

${ }^{326}$ United States v. Carolene Products Co., 304 U.S. I44, I52 n.4 (1938).
} 
wrong. ${ }^{327}$ While the process of reaching those decisions in public law adjudication may look different - as it should - this difference in form should not obscure the fact that the court is engaging in one of its most traditional functions: the enforcement of constitutional rights. And that the enforcement may include as one component judicially imposed negotiations between the adversary parties can hardly be considered truly extraordinary in a system which places as much value and as much confidence in process itself as ours does. ${ }^{328}$

A final question of the legitimacy of systemic relief deals with its pure federalism aspects: the fact that public law adjudication frequently gives rise to reforms of state and local governmental institutions at the direction and under the supervision of an arm of the federal government - the federal courts. To speak of the concept of "federalism" as an absolute limit on the permissible scope of the section 1983 action, as perhaps intimated by the Supreme Court in Rizzo v. Goode, ${ }^{329}$ is to ignore the critical impact of the passage of the fourteenth amendment, which section r 983 seeks to implement. ${ }^{330}$ While concerns of federalism may dictate some deference by federal institutions to state decisions and processes, states and localities are limited in the exercise of their powers by the dictates of the fourteenth amendment. Indeed, the Supreme Court itself emphasized last Term in Fitzpatrick v. Bitzer: ${ }^{331}$

The substantive provisions [of the fourteenth amendment] are by express terms directed at the states. Impressed upon them by those provisions are duties with respect to their treatment of private individuals. Standing behind the imperative is Congress' power to "enforce" them "by appropriate legislation." ... [I] n exercising her rights, a State cannot disregard the limitation which the Federal Constitution has applied to her power. Her rights do not reach to that extent. ${ }^{332}$

And it was to the federal courts that the Reconstruction Congress entrusted the responsibility to enforce the guarantee of the fourteenth amendment. ${ }^{333}$ Thus, once a constitutional right is identified, the federal system as adjusted by the fourteenth amendment recognizes a legitimate restriction on state and local authority

\footnotetext{
${ }^{327}$ See, e.g., Roe v. Wade, 410 U.S. II3 (I973); A. Cox, supra note 297, at $50-55$, I I I-I 5 .

${ }^{328}$ See also Tribe, Structural Due Process, ro HaRv. C.R.-C.L. L. REv. 269 ( 1975 ).

${ }^{329} 423$ U.S. $362,377-80$ (1976). See The Supreme Court, 1975 Term, supra note 90 , at $238-47$.

${ }^{330}$ See p. I 155 supra.

${ }^{331} 427$ U.S. 445 (r976).

${ }^{332} I d$. at 2670-7 I (quoting Ex parte Virginia, I00 U.S. 339,346 (I880)).

${ }^{333}$ See pp. I I47-53 supra.
} 
and the federal courts are empowered to enforce that restriction under traditional equity powers.

This is not to say that federalism concerns have no place in section 1983 adjudication. The expansion of the scope of rights protected by the fourteenth amendment and the shift in the 1983 action from an individualized dispute between the citizen and public officials to an action often designed to reform wide-ranging governmental institutions creates a potential for federal judicial involvement in state and local affairs to an extent unknown in $187 \mathrm{I}$. But this potential should not be considered as a bar to any relief; rather, it is an element which must be considered by the courts in exercising equitable powers to determine the most appropriate form of relief.

"The essence of the equity jurisdiction has been the power of the Chancellor to do equity and to mould each decree to the necessities of the particular case. Flexibility rather than rigidity has distinguished it. The qualities of mercy and practicality have made equity the instrument for nice adjustments and reconciliation between the public interest and private needs as well as between competing private claims. ..." The task [of the courts] is to correct, by a balancing of the individual and collective interests, the condition that offends the Constitution. ${ }^{334}$

Properly understood, then, considerations of federalism - which include both respect for the autonomy of state and local governmental units and a recognition that the Constitution places affirmative limits on the manner in which such units implement policy choices - should analytically be subsumed in the principles of equity which must underlie the grant of systemic relief in section I983 actions.

3. An Incremental Approach to Systemic Relief. - If the courts can and should act in the face of systemic violations of constitutional rights, the question remains what standards or procedures should guide their remedial action. While "the controlling principle consistently expounded .... is that the scope of the remedy is determined by the nature and extent of the constitutional violation," ${ }^{335}$ equity leaves the courts with broad flexibility to shape appropriate relief. It is, of course, impossible to lay down with any degree of specificity a set of general rules to govern every section 1983 public law action; as the Supreme Court has recognized, principles of equity require that each case of a constitutional violation be remedied only after a particular-

\footnotetext{
${ }^{334}$ Swann v. Charlotte-Mecklenburg Bd. of Educ., 402 U.S. I, I5-I6 (I97I); see Chayes, supra note 200 , at $1292-96$.

${ }^{335}$ Milliken v. Bradley, 4I8 U.S. 717, 744 (1974); Swann v. CharlotteMecklenburg Bd. of Educ., 402 U.S. I, I6 (I971).
} 
istic examination of all the factors relevant to that case. But it may be possible to lay down a set of generally accepted procedures to structure affirmative relief, and to identify the concerns that each court must bear in mind in framing such relief.

Concerns of judicial competency and federalism suggest that the procedures employed in framing relief ought to allow for the maximum input and control by responsible government officials. From the point of view of competency, these are the individuals most likely to enjoy expertise in precisely those areas where the court is lacking: knowledge of detailed local circumstances, financial constraints, and the political realities of the locality. As a result, their participation may be critical to the development of a workable remedy - and one they are willing to implement. Their input and control are equally significant in federalism terms: to the extent that local officials assume the predominant role in shaping relief (which must, of course, be approved by the courts), the primary responsibility for the direction of governmental operations is maintained in the individuals to whom it was entrusted by the political process.

These advantages have not been lost on the courts; in each of the cases described earlier, the court sought a proposed plan from the defendant officials before being forced to consider shaping one of it own over their objections. Absent clear proof of an intention of noncompliance by the defendants, it would seem that initial restraint is always the appropriate course for the federal court, with the judge adopting a more activist role which may expose him to charges based on competency and interference - only incrementally, in the face of default by government officials.

The court's first step should be to issue a form of declaratory judgment, placing the defendants on notice of the constitutional violation and retaining jurisdiction to determine whether the defendants have remedied the violations on their own initiative. In cases where a declaration of rights would not serve adequately to protect the plaintiffs, the court should issue a simple, prohibitory decree to prevent continuing injury while still relying on the defendants to initiate corrective measures.

In the face of recalcitrance by governmental officials to such first-level declaratory or injunctive action, the proper next step is for the court to frame a decree requiring the government defendant to submit to the court, for approval and review, a plan for remedial action which will either demonstrate that continuing jurisdiction is not required or permit it to embody the proposal in an affirmative mandatory injunction. While the local officials are now under external judicial compulsion to exercise their 
policy formulation and implementation powers, they retain, within constitutional limits, their discretion in doing so. The compulsion involved, it would seem, is the minimum required by the fourteenth amendment.

In passing on the acceptability of such a plan (or in seeking to draw up a plan of its own following the submission of an unsatisfactory one), the court may properly seek to secure additional input both from representatives of the plaintiff class and from others who will either be affected by a decree or who possess special expertise which may be valuable to the court. Courts should, however, still give credence to the policy judgments of local officials; it is not necessary that a remedial effort secure the ideal operation of the governmental institution or program in question; all that is required is compliance with minimum constitutional standards.

Should the remedial plan proffered by the defendants fail even after reasonable opportunities to amend - to provide a realistic chance of remedying the violations identified by the court, the obligation will fall upon the judge to develop a decree. His first step in this effort should be to call together the parties to the litigation for decree negotiation. As Professor Chayes has noted, the judge may participate actively in such negotiations, channeling the discussions of the parties in order to ensure that any decree that emerges will both meet constitutional minimal standards and respect, to the greatest extent possible, the judgments and autonomy of the local government unit. ${ }^{336}$ If these negotiations prove fruitless, or if the defendants demonstrate continued unwillingness to participate reasonably in the process, the judge will be required to formulate a decree on his own initiative. Depending upon the amount of evidence already available and the complexity of the case, the court may choose to design the relief itself or to employ special masters to conduct further hearings and recommend a remedy. In any hearings conducted, evidence may be taken not only from the parties, but also from other concerned governmental agencies, affected citizens, and experts in the field. ${ }^{337}$ But again, proper respect for the local governmental unit and, perhaps more important at this point, the recognition that implementation will ultimately lie in its hands, suggests that the court take account of the suggestions and objections of the defendants with respect to any proposed plan.

The imposition of affirmative injunctive relief inevitably involves an intrusion upon the operations of local government units - an intrusion that is required by the fourteenth amend-

${ }^{336}$ See Chayes, supra note 200 , at 1307-16.

${ }^{337}$ See pp. 1236-39 supra. 
ment. The incremental steps outlined above seek to minimize this intrusion, not by reducing the standards for a constitutionally acceptable system but rather by placing greatest reliance on the defendant officials to bring their own system into compliance. Even a judge who scrupulously follows these steps, however, may find himself, like Judge Garrity or Judge Lasker, in a position where he must fight the defendants at each stage and where his legitimacy and effectiveness may appear to be in some jeopardy. But that should not be taken to mean that systemic relief is inappropriate in such cases. To be sure, the opposition of political leaders and of the community may in reality place limits on how far the courts can go and how much they can accomplish; this is true, however, not only in the imposition of relief but also in the initial interpretation and declaration of constitutional rights. Ultimately, though, the resistance of the local government unit must be taken as evidence not of a case in which federal court intervention is inappropriate, but rather as one in which enforcement by the federal courts of the dictates of the fourteenth amendment against government units is most essential. Such cases provide not the exception to federal jurisdiction, but the most basic reason for it.

\section{Pullman Abstention}

Pullman abstention takes its name from the 194I Supreme Court decision in Railroad Commission v. Pullman Co., ${ }^{1}$ where Justice Frankfurter first clearly articulated the equitable doctrine that federal courts should decline to exercise their jurisdiction in cases containing unsettled issues of state law that could moot or alter the federal constitutional claim. Pullman itself involved an attack on an order of the Texas Railroad Commission requiring Pullman conductors to be continuously present in all sleeping cars. ${ }^{2}$ As was "well known," all Pullman conductors at that time were white while all Pullman porters were black; prior to the regulation, the black porters supervised sleeping cars where local passenger traffic was slight. ${ }^{3}$ The order was challenged as unauthorized by state law and as violative of the constitutional guarantees of equal protection and due process, as well as of the commerce clause. Justice Frankfurter, writing for a unanimous Court, acknowledged that the three-judge court convened to decide the case included "an able and experienced circuit judge of the circuit which includes Texas" and "two capable district

\footnotetext{
1312 U.S. 496 (r94I).

2 Id. at $497-98$.

${ }^{3} I d$. at 497 .
} 
judges trained in Texas law." 4 Nonetheless, he rejected their conclusion that the order was beyond the authority of the Commission under state law, holding instead that the court should retain jurisdiction until the parties had had an opportunity to obtain a decision on this question of state law from the state court. ${ }^{5}$ According to the Court, "[t]he resources of equity are equal to an adjustment that will avoid the waste of a tentative decision as well as the friction of a premature constitutional adjudication." 6

In the years following Pullman, the Supreme Court has repeatedly - if inconsistently - invoked the abstention doctrine to foreclose federal court jurisdiction to decide unsettled issues of state law properly before them. In the process, the costs of abstention have emerged fairly clearly; the contours of the doctrine, however, generally have not.

Ostensibly, abstention in constitutional cases results only in the postponement of the federal court's decision until after state resolution of the uncertain issues of its own law. ${ }^{7}$ Under the procedure announced in England v. Louisiana State Board of Medical Examiners, ${ }^{8}$ plaintiffs, by filing a formal reservation, may preserve their federal forum for any federal question not voluntarily litigated in state court. ${ }^{9}$ State court adjudication of the state law issues, however, may itself be a time-consuming and costly process. As a result, litigants temporarily foreclosed from federal court by the abstention doctrine may well waive their right to return by submitting all questions to the state court in order to avoid a subsequent round of litigation. ${ }^{10}$ Where they do not, the delay in the final resolution of the suit and the costs of piecemeal litigation represent a substantial burden both for the parties and for the judicial system. ${ }^{11}$ In either case,

${ }^{4}$ Id. at 499 .

${ }^{5} I d$. at $50 \mathrm{I}-02$.

${ }^{6} I d$. at 500 .

${ }^{7}$ Of course, abstention may result in avoiding a federal decision altogether if the state court invalidates the challenged action on state law grounds.

8375 U.S. 4II (1964).

${ }^{9} I d$. at $42 \mathrm{I}-22$. The federal court ordinarily should prefer retention of jurisdiction after abstaining to dismissal, see American Trial Lawyers Ass'n v. New Jersey Supreme Court, 409 U.S. 467 (1973), although dismissal may be proper if the state court would otherwise refuse to issue a declaratory judgment, see Harris County Comm'rs Court v. Moore, 420 U.S. 77, 88 \& n. I4 (1975).

${ }^{10}$ This was the course followed after abstention in Harrison v. NAACP, 360 U.S. 167 (1959). The NAACP subsequently obtained direct review of the constitutionality of the state statutes in question. NAACP v. Button, 37I U.S. 415 (1963). See also Fisher v. Civil Serv. Comm'n, 484 F.2d Iog9 (Ioth Cir. I973).

${ }^{11}$ It is not uncommon for abstention to entail delays of several years before the case is finally decided on the merits, see, e.g., Spector Motor Service, Inc. v. O'Connor, 340 U.S. 602 (I95I) (seven years); England v. Louisiana State Bd. 
though, abstention serves at least to burden, if not to eliminate, the plaintiff's legitimate choice of a federal forum to adjudicate his claims. And it does so without any guarantee that the highest court of the state will ever hear the suit and rule authoritatively on the disputed state law issues. ${ }^{12}$

Traditionally, two policies have been relied on to justify abstention in constitutional cases: that of avoiding federal constitutional questions where other grounds of decision may be available, ${ }^{13}$ and that of avoiding the intrusiveness and disruption of erroneous constructions of state law. ${ }^{14}$ The former policy requires a federal court to resolve all state law claims raised by a litigant which might dispose of or alter his federal constitutional claim prior to addressing that claim..$^{15}$ Abstention becomes an issue where the state law question is unclear, and there is a danger that the federal court will reach a conclusion different from that which the highest state court would reach. To do so, according to traditional thinking, would involve wasted judicial resources, unnecessary intrusion upon state activities, and the possibility of an unnecessary holding on the merits of the federal constitutional claim. ${ }^{16}$

Whatever the wisdom of these policies, it is at least clear that they have not served to confine the doctrine within any welldefined limits. The desire to avoid both constitutional questions and erroneous constructions of state law raises the abstention issue in a broad range of cases, while the criterion of clarity of state law - which then serves as the primary basis for determining the appropriateness of abstention - is itself sufficiently ambiguous to be open to substantial manipulation. ${ }^{17}$ Although

of Medical Examiners, 384 U.S. 885 (1966) (six years), or is disposed of inconclusively, see United States v. Leiter Minerals, Inc., 38I U.S. 413 (1965) (dismissed as moot eight years after abstention ordered).

${ }^{12}$ See Field, The Abstention Doctrine Today, 125 U. PA. L. Rev. 590, 604-05 (1977).

${ }^{13}$ See Railroad Comm'n v. Pullman Co., 312 U.S. 496, 498 (194I); Lake Carriers' Ass'n v. MacMullan, 406 U.S. 498, 5 10-II (1972); Field, Abstention in Constitutional Cases: The Scope of the Pullman Abstention Doctrine, 122 U. PA. L. REv. I071, IO96-IIOI (1974).

${ }^{14}$ See Railroad Comm'n of Texas v. Pullman Co., 312 U.S. 496, 500 (194I); Field, supra note 13, at 1093-96; Note, Federal-Question Abstention: Justice Frankfurter's Doctrine in an Activist Era, 80 HARv. L. Rev. 604, 617-19 (1967).

${ }^{15} \mathrm{See}$ Siler v. Louisville \& N. R.R., 213 U.S. 175,193 (1909). It is, of course, firmly settled that federal courts have jurisdiction to decide such state law matters. See id. at I9I; United Mine Workers v. Gibbs, 383 U.S. 715, 725 (I966).

${ }^{16} \mathrm{See}$ notes $\mathrm{I}_{3} \& \mathrm{I} 4$ supra.

${ }^{17}$ Compare Fornaris v. Ridge Tool Co., 400 U.S. 4I, 44 (I970) (abstention proper because "conceivable" that the statute "might be judicially confined to a more narrow ambit") (emphasis added), and Harrison v. NAACP, 360 U.S. 167, 
the Supreme Court has repeatedly stated that abstention is only justified in "narrowly limited special circumstances" ${ }^{18}$ where the need to avoid constitutional decisions on erroneous constructions of state law is most pressing, its practice has often belied such rhetoric: its decisions, as well as the positions taken by individual Justices, often seem to be explainable only in terms wholly unrelated to the traditional policies of the doctrine. ${ }^{19}$ Indeed, the costs of even a "legitimate" abstention, coupled with the doctrine's realized potential as an illegitimate device to foreclose and delay, have led many commentators to argue that Pullman abstention should be abandoned altogether ${ }^{20}$ or confined to instances where the state has made procedures available for certifying such unsettled questions to its highest court. ${ }^{21}$ But the doctrine continues

I77 (I959) (abstention ordered where Court could not "agree that the terms of these three statutes leave no reasonable room for a construction ... which might avoid" or alter the constitutional question) (emphasis added), with Harman v. Forssenius, 380 U.S. 528, 534-35 (1965) (abstention inappropriate "[i]f the state statute in question, although never interpreted by a state tribunal, is not fairly subject to an interpretation" avoiding or modifying a federal constitutional question) (emphasis added).

${ }^{18}$ See, e.g., Lake Carriers' Ass'n v. MacMullan, 406 U.S. 498, 509 (1972); Zwickler v. Koota, 389 U.S. 24I, 248 (1967).

${ }^{19}$ See Field, supra note $\mathrm{I} 2$, at $602 \& \mathrm{n} .52$ (suggesting that delay is "sometimes the aim of the abstention procedure, and the desirability of obtaining a clarifying state decision simply the excuse for the delay," and depicting the shifts in positions of individual Justices according to the underlying issues at stake).

${ }^{20}$ See England v. Louisiana State Bd. of Medical Examiners, 375 U.S. 4II, 426 (I964) (Douglas, J., concurring); Currie, The Federal Courts and the American Law Institute (pt. 2), 36 U. CHI. L. Rev. 268, 3I7 (1969). It has sometimes been suggested that some or all civil rights cases be exempted from the abstention doctrine, see Wechsler, Federal Jurisdiction and the Revision of the Judicial Code, I3 Law \& Contemp. Prob. 216, 230 (1948) (abstention inadvisable in suits brought under a civil rights act); ALI, STUdy of THE Division of JURIsdiction Between State and Federal Courts 297-98 (1968) (abstention improper in cases alleging denial of voting rights or of equal protection of the laws where denial is on "basis of race, creed, color, or national origin"), despite the frequently observed fact that Pullman itself was a civil rights case, see P. BATOR, P. MIsHKIN, D. Shapiro \& H. Wechsler, Hart and Wechsler's The Federal Courts and the Federal System 99i (2d ed. I973) [hereinafter cited as Hart \& Wechsler].

${ }^{21}$ See Field, supra note 12 , at 605-09. Numerous states have adopted legislation permitting the highest court to receive and answer questions certified to it by federal appellate courts, see, e.g., Colo. APP. R. 21.1 ; Fla. Stat. § 25,03I (I946); Haw. Rev. Stat. \$\$ 602-636 (1965), and it has been suggested that Congress could require states to entertain certified questions, see Kurland, Mr. Justice Frankfurter, The Supreme Court and the Erie Doctrine in Diversity Cases, 67 YalE L.J. I87, 214 (1957), or that federal courts might compel certification, even without congressional authorization, see Note, Consequences of Abstention by a Federal Court, 73 HaRv. L. REv. 1358, 1359-60 (1960). Because certification reduces the time and expense accompanying abstention, it has generally been well received by commentators. See, e.g., Kurland, Toward a Co-operative Judicial Federalism: The Federal Court Abstention Doctrine, 24 F.R.D. 48I, 489-90 (I960); ALI, 
to survive despite such arguments, and closer examination of its underlying theoretical bases becomes necessary both as a guide to where its invocation may be supportable - if expensive and as a source of insight into the underlying concerns for federalstate relations which must serve as the ultimate justification for its continued vitality.

\section{A. The Threshold for Considering Abstention:}

The Need to Decide an Unclear Question of State Law

The issue of the appropriateness of Pullman abstention arises in two paradigmatic types of cases: those in which the federal and state claims are interdependent, in the sense that resolution of the state law issue is integrally related to the constitutional claim itself, and those in which the two claims are wholly independent and separable. The first paradigm includes both cases challenging the application of a statute itself ${ }^{22}$ and those challenging actions by executive or administrative bodies purportedly taken under statutory authorization. ${ }^{23}$ In the case of the former, the state law issue which may be unclear is the meaning of the statute, and the constitutional question of its validity may be avoided or altered by its construction; in the case of the latter, the issue of state law relates to whether the statute authorizes the challenged action, and a holding that it does not will moot the constitutional claim. In both these instances, the policy against unnecessary or premature constitutional decisions dictates that the state law issue first be settled; indeed, in the former, it is not even necessary to invoke this policy, since some resolution of the statute's meaning is necessary to any decision on its constitutionality. The policy of avoiding constitutional decisions, however, does more than establish the proper order of adjudication; if one accepts the wisdom of the rule at all, it also mandates that the initial decision construing the meaning or authority of the state statute be made in light of the potential constitutional problems to be raised by adopting one or more of the possible constructions. Thus, the Supreme Court has held that where the federal court abstains, the state court must be made aware of the nature of the constitutional challenge which might then inform the construction adopted. ${ }^{24}$ Certainly, it would make little sense to abstain on an issue of state law in order to avoid an

supra note 20, at 292-96 (proposed 28 U.S.C. \& $137 \mathrm{I}(\mathrm{e})$ ). But see Mattis, Certification of Questions of State Law: An Impractical Tool in the Hands of the Federal Courts, 23 U. Miami L. Rev. 7 I7 (1969).

${ }^{22}$ See, e.g., Harrison v. NAACP, 360 U.S. 167 (1959).

${ }^{23}$ See, e.g., Railroad Comm'n v. Pullman Co., 3 I2 U.S. 496 (I94I).

${ }^{24}$ Government \& Civic Employees Organizing Comm. v. Windsor, 353 U.S. 364,366 (1957). 
unnecessary constitutional question and then to require the state court, in reaching its authoritative conclusion, to ignore the presence of an underlying constitutional problem with the result that a statute that might have been construed so as to remain valid ultimately must be struck down on constitutional grounds.

The justification and logic of the rule of statutory construction that courts ought to construe statutes to avoid constitutional problems ${ }^{25}$ — and not ascribe to the legislature, in the absence of some clear statement, an intent to enact an arguably unconstitutional law or delegate powers to act in an arguably unconstitutional manner ${ }^{26}$ - call into question the premise of separability which underlies abstention procedure. To the extent that federal constitutional law becomes relevant in the state court determination, the argument that abstention, apart from its costs, serves as an ideal means of allocating decisionmaking responsibility by entrusting to state courts the questions of purely state law and to federal courts those of purely federal law necessarily becomes attenuated. ${ }^{27}$

In any event, though, it is evident that the threshold for abstention in such cases should be that the statute appears capable not simply of one constitutional construction, but of a number, with the correct constitutional interpretation posing the question of unclear state law. If a statute is incapable of a constitutional construction, it is largely irrelevant that it is susceptible of a number of impermissible ones. Thus, the Supreme Court has refused to require abstention in suits seeking anticipatory relief from allegedly overbroad or vague laws where it was not evident that the statute could be cured in a single proceeding. ${ }^{28}$

${ }^{25}$ See Ashwander v. Tennessee Valley Auth., 297 U.S. 288, 348 (1936) (Brandeis, J., concurring) ; Crowell v. Benson, 285 U.S. 22, 62 (I932).

${ }^{26}$ The practice of narrowly construing a statutory delegation of power to an administrative agency so as to avoid serious constitutional questions is quite common. See, e.g., Gutknecht v. United States, 396 U.S. 295 (1970); Greene v. McElroy, 360 U.S. 474 (1959); Kent v. Dulles, 357 U.S. II6 (1958). Thus, in Kent, the Court held that because Congress had "made no such provision in explicit terms," id. at I30, it would not "impute to Congress" the intention to give the Secretary of State authority to withhold passports from citizens because they were Communists, id. at $\mathrm{r} 28$. The Court noted that had there not been the possibility of the narrowed construction, it would have been "faced with important constitutional questions." Id. Of course, it is just that sort of "clear statement" which would make abstention inappropriate in any case.

${ }^{27}$ See Field, supra note 13 , at 1084-85; Kurland, supra note $2 \mathrm{I}$, at 487-90.

${ }^{28}$ See, e.g., Dombrowski v. Pfister, 380 U.S. 479, 49I (1965) ; Baggett v. Bullitt, 377 U.S. 360,378 ( 1964$)$. Of course if no limiting construction at all were possible, see, e.g., Zwickler v. Koota, 389 U.S. 24I, 249-50, 254 (I967), abstention would be inappropriate in any event. In such a case the availability of federal anticipatory relief would depend on whether the plaintiff had standing to challenge the overbroad law. 
Abstention in favor of a series of state court "as applied" adjudications would not dissipate the uncertainty regarding the reach of the statute which is itself the substantive defect addressed by the overbreadth doctrine. ${ }^{29}$ Moreover, where only one arguably constitutional interpretation is conceivable, there is again no need to abstain, because the federal and state courts would presumably both adopt this same construction. ${ }^{30}$ Only where there are a number of permissible constructions is the requisite possibility of erroneous decisionmaking by the federal courts even introduced.

The threshold for considering abstention in cases within the second paradigm is reached somewhat differently. In such cases the question of state law is independent of the federal claim, as where the unclear state law is itself remedial ${ }^{31}$ or is only incidentally related to the federal question. ${ }^{32}$ The fact that the construction of state law will not be colored by considerations of federal law may make abstention seem more desirable, at least in theory. The independence of the state and federal claims, however, also calls into question the need in every case to decide the state claim, which poses the abstention question, first. While the Supreme Court has required abstention where the case may turn on the interpretation of a specialized state constitutional provision, ${ }^{33}$ it has held abstention improper in cases involving state and federal constitutional provisions which are identical or substantially similar, ${ }^{34}$ notwithstanding the possibility of avoid-

${ }^{29}$ See Note, The First Amendment Overbreadth Doctrine, 83 HARv. L. REv. $844,901-07$ (1970).

${ }^{30}$ A reluctance on the part of federal courts to "rewrite" state statutes, however, may on occasion lead them to abstain in such cases. This seems to be the theory pursued by Justice Black in his dissent in Wisconsin v. Constantineau, 400 U.S. $433,443-45$ ( $197 \mathrm{I}$ ), where despite the clarity of the statute in question, he thought the state courts might find the saving provision of notice and hearing in "the body of other state law." See also Boehning v. Indiana State Employees Ass'n, 423 U.S. 6, 7 (1975); Field, supra note 13, at III7-18.

${ }^{31}$ This will often be the case when the remedial law in question is a provision of the state constitution. See, e.g., Askew v. Hargrave, 40 I U.S. 476, 478 (I97I); Reetz v. Bozanich, 397 U.S. 82, 87 (1970).

${ }^{32}$ See Harris County Comm'rs Court v. Moore, 420 U.S. 77, 88 (1975); cf. Bishop v. Wood, 426 U.S. 34I (1976) (due process claim dependent on construction of statutory entitlement).

${ }^{33}$ See Reetz v. Bozanich, 397 U.S. 82, 87 (1970); Harris County Comm'rs Court v. Moore, 420 U.S. 77, 84 n.8 (I975) (abstention appropriate "where the challenged statute is part of an integrated scheme of related constitutional provisions, statutes, and regulations, and where the scheme as a whole calls for clarifying interpretation by the state courts").

${ }^{34}$ See Examining Bd. of Eng'rs, Architects \& Surveyors v. Flores de Otero, ${ }_{426} 6$ U.S. 572, 597-98 (1976). Otero involved a challenge to a Puerto Rican statute excluding aliens from private practice as civil engineers. Rejecting the argument that the federal court should abstain because the statute might be held to violate the provision of the Puerto Rican constitution guaranteeing equal protection, the 
ing the federal constitutional claim. Certainly, where the challenged conduct or statute is clearly in violation of the Federal Constitution, whether or not valid under the independent state law claim, it is difficult to see any real purpose other than delay or some preference for state adjudication which is served by initially requiring a ruling, authoritative or otherwise, on state law grounds. $^{35}$ Moreover, in challenges to statutes on overbreadth or vagueness grounds, the delay resulting from abstention merely prolongs the chilling effect which serves as the basis of the substantive constitutional claim. Only where the federal constitutional claim is as unclear as the state claim - or where the federal claim is likely to be decided against the plaintiff - can one justifiably invoke the policy of avoiding constitutional questions to render decision of the unclear state law claim critical, and to raise the abstention issue. Only here, in other words, is the danger of "erroneous" decisions of state law present.

\section{B. The Likelihood and Impact of Error in Federal Decisions of Unclear Questions of State Law}

Mere recognition of the possibility of an erroneous federal determination of an issue of state law is hardly a mandate for broad use of abstention, in either the first or second paradigm. To speak in terms of error is itself somewhat deceptive, suggesting as it does that in some objective sense a federal court will reach the wrong result where a state court would reach the right one. Rather, the point is that because the highest court of the state $i s$ the ultimate arbiter of the law of that state, ${ }^{36}$ a prior inconsistent decision of the same point by a federal court is by definition incorrect. The task of the federal court, then, becomes one of prediction, with the tools available for its use - precedents on point or in analogous areas, legislative history, and the like inversely determining the initial weight of the argument for abstention. Even in cases posing substantial problems of prediction under these standards, though, it is critical, given the costs

Supreme Court said that to abstain because of the "broad and sweeping" constitutional provisions in question "would convert abstention from an exception into a general rule." .Id. at 598 . See P. Bator, P. Mishkin, D. Shapiro \& H. Wechsler, Hart \& Wechsler's The Federal Courts and the Federal System i6o (2d ed. Supp. 1977).

${ }^{35}$ See Field, supra note ${ }^{3} 3$, at $1117-18$; Field, supra note 12 , at 602-04. Thus, if the entitlement to a federal remedy is sufficiently clear, it should be irrelevant that there may be a remedy under state law, whether clear or ambiguous. See Davis v. Mann, 377 U.S. 678, 689-91 (1964); McNeese v. Board of Educ., 373 U.S. 668,674 (1963); Turner v. City of Memphis, 369 U.S. 350,353 (I962).

${ }^{36}$ See Scripto, Inc. v. Carson, 362 U.S. 207 (1960); Murdock v. Memphis, 87 U.S. (20 Wall.) 590 (1875); C. Wright, LaW of the Federal Courts 488 (1970). 
of abstention and the federal interests also at stake, to examine realistically both the likelihood and the impact of inconsistent decisions by federal and state courts.

In one sense, abstention may be a response to the strictures placed on federal courts deciding state law questions by cases following in the wake of Erie. ${ }^{37}$ To the extent that federal courts feel themselves bound by clearly outdated precedents and clearly erroneous reasoning, then the chances of "error" in their construction of state law are substantial. ${ }^{38}$ But abstention need not be the only response to such problems; a better one - and one more consistent with Erie - is to allow federal judges to deal with discredited precedents as their state court counterparts would, freeing them in fact to engage in the practice of deciding state law issues as they would reasonably expect the highest state court to do. ${ }^{39}$ Thus freed, concern that they will err in this process is substantially reduced.

Certainly, federal judges are not generally inept at examining state legislative history or at understanding prior rulings of state courts; they perform these tasks regularly in the exercise of their diversity jurisdiction. While state judges may bring greater experience with the law of their state to bear on the construction of state law, to the extent that this experience is the product of their prior decisions, these decisions are available for their federal counterparts to examine. Indeed, as a general matter, it would seem that where the state courts have the greatest claim to special expertise and sensitivity in construing statutory schemes, the case for abstention is in fact likely to be least compelling because of the availability of clarifying legal materials which comprise the body of state law. Moreover, the process of federal decisionmaking does not exclude representatives of the state; even apart from the fact that federal district court judges must be residents of the states in which they sit, ${ }^{40}$ adjudication in the federal court will be informed by the views of the interested state representatives, either through their direct participation as original parties

${ }^{37}$ Erie R.R. v. Tompkins, 304 U.S. 64 (1938).

${ }^{38}$ The rule that a federal court in a diversity action must follow the decision of an intermediate appellate state court in the absence of clear evidence that the highest court of the state would decide differently produced some extraordinary results. See Gustin v. Sun Life Assurance Co., 154 F.2d 96I (6th Cir.), cert. denied, 328 U.S. 866 (1946); Fidelity Union Trust Co. v. Field, 3 II U.S. I69 (I940) ; C. WRIGHT, supra note 36 , at 236-37.

${ }^{39}$ See Commissioner v. Estate of Bosch, 387 U.S. 456, 465 (1967). This is in fact the prevailing practice under Erie today. See, e.g., Bernhardt v. Polygraphic Co. of America, 350 U.S. 198 (1956) ; King v. Order of United Commercial Travelers of America, 333 U.S. 153 (I948) ; C. WRIGHT, supra note 36, at 237-40.

${ }^{40} 28$ U.S.C. $\S \mathrm{I} 34$ (b) (1970). 
or through their intervention ${ }^{41}$ or amicus argument. ${ }^{42}$ To be sure, there may be slight differences in sensitivity at the margins, with the state courts more responsive to arguments based on state concerns and the federal courts tending to be more attuned to federal constitutional concerns. But the weight of these factors is limited by the contexts to which the abstention question has already been confined in the first paradigm, to a choice among possible constitutional constructions of a statute or grant of authority; in the second, to an issue of purely state law. Moreover, even if a state court were ultimately to adopt a different construction than one earlier embraced by a federal court, the waste involved and the dangers presented by the erroneous federal determination are easily overstated: justice has ordinarily been done between the parties before the court, ${ }^{43}$ and established procedures allow the subsequent state determination to override any continuing injunction based on the federal adjudication. ${ }^{44}$

These considerations suggest that, in view of the costs involved and, in section 1983 cases, the strong federal interest in providing an effective forum to enforce civil rights, a decision to abstain can be justified on only two grounds: the particular and peculiar dangers of contrary federal and state court decisions in a certain area or some broader notions of the symbolic role or position of state courts. The former criterion is fairly straightforward: in areas of continuing state responsibility governed by complex statutory and regulatory schemes, the costs of inconsistent decisions may be striking, and even the possibility of such inconsistency should be avoided. What seems critical in such cases is not so much the fact that the area is in any definable

${ }^{41}$ See FED. R. Civ. P. 24 (b)

42 See Fed. R. Civ. P. 29.

${ }^{43}$ At one level, litigants have no claim of injustice so long as the federal court adjudication provided them a full and fair opportunity to present their claims, whether or not the result turns out to be inconsistent with a subsequent ruling of the highest court of the state. But even if one defines "injustice" by reference to later authoritative state rulings, "justice" will be done in the run of cases. The exceptions would be those rare cases where the court erroneously denies relief via its construction of state law and then also refuses constitutional relief, see Note, supra note 14 , at $6 \mathrm{I}_{4}$, and those in which a federal court erroneously grants relief on state law grounds when it would have rejected the constitutional claims. But cases in which the only strong claim is grounded in state law are infrequently litigated within the federal question jurisdiction. See id. at 6ra n.75.

${ }^{44}$ Federal courts frequently will subject equitable decrees to reopening if state courts later reach an inconsistent construction of an underlying question of state law, see, e.g., Lee v. Bickell, 292 U.S. 415, 425-26 (1934); Glenn v. Field Packing Co., 290 U.S. I 77 (I933), thus making the determination of the state law question tentative even between the parties to the federal suit. 
sense "local" in nature, ${ }^{45}$ but rather that it is one in which the disruption owing to a mistaken construction by the federal court would be of greatest significance. ${ }^{46}$ But even here, the federal interest cannot be ignored; to the extent that abstention might delay or jeopardize the vindication of rights secured by the Federal Constitution - resulting in harms of a truly irreparable nature - abstention remains difficult to justify. And even in the limited category of cases which may fit within this justification, less drastic means may be available to the federal court to limit the potential disruption of a subsequent inconsistent decision without resorting to the burdensome process of absention. For example, not only can the federal court generally restrict itself to declaratory as opposed to injunctive relief, but it can also refuse to adjudicate any claim of facial invalidity, thus limiting itself to a holding applied only to the particular plaintiffs before the court. ${ }^{47}$ If the state finds such a holding unacceptable - or if it would prefer an authoritative decision by the state courts - in most situations it will be able to seek such a ruling, at its own expense and without jeopardizing the constitutional rights of the federal plaintiffs, by seeking a declaratory judgment or initiating an enforcement action in state court. Given such alternatives, and in view of the costs inherent in abstention, resort to that doctrine even within this limited category of cases becomes highly questionable.

Moreover, this justification is wholly inapplicable to some of the cases in which the Supreme Court has in fact ordered abstention. ${ }^{48}$ If these decisions are capable of justification, it must be on the basis of some judgment that the state courts are the most appropriate body to decide certain issues which will often require them to act in a quasi-legislative capacity - not because they will reach decisions which are indeed different from those

${ }^{45}$ Compare Louisiana Power \& Light Co. v. City of Thibodaux, 360 U.S. 25 (1959), with County of Allegheny v. Frank Mashuda Co., 360 U.S. 185 (1959).

${ }^{46}$ It was partly the susceptibility of the state oil and gas regulatory scheme to disruption by federal court injunctions that led the Court to order dismissal in Burford v. Sun Oil Co., 319 U.S. 315 (1943). See pp. 126r-63 infra.

${ }^{47}$ The flexibility of a declaratory judgment ordinarily ought to permit the court to afford some relief from uncertainty to the federal plaintiff. An "as applied" adjudication would permit the court to immunize protected conduct from state interference, without reaching the more difficult task of choosing among various arguable constructions of the state law. Thus abstention may have been unnecessary in Harrison v. NAACP, 360 U.S. 167, 177 (1959). In some cases, an "as applied" adjudication could hold that it is procedurally impermissible for the state to behave in a certain manner, but refrain from specifying the procedures which would cure the statute. See Wisconsin v. Constantineau, 400 U.S. 433 (197x).

${ }^{48}$ See pp. $126 \mathrm{x}-63$ infra. 
a federal court would reach, but rather because they are state courts. This preference for state courts may rest on a number of grounds: the greater perceived legitimacy or accountability of state as opposed to federal judges, the notion that the state court is an integral part of the state government as a whole, with positive values attaching to self-correction within that unit, and even the view formally rejected in Home Telephone \& Telegraph Co. v. City of Los Angeles, ${ }^{49}$ that one should have no cause to complain of a constitutional deprivation until after the state machinery has had an opportunity to correct any prior errors.

The concern to which these factors are addressed - that there may be certain areas of decision where state adjudication is to be preferred for its own sake - does not neatly correspond to the cases in which the argument for abstention according to traditional policies is strongest. This lack of correspondance may in part explain the apparent confusion in the case law and the difficulty which one faces in attempting to analyze the pattern of Supreme Court decisions according to the articulated policies of abstention. But it seems clear not only that resort to abstention to avoid constitutional questions and errors of state law cannot be justified on the basis of what is at most a minimal risk of harm from unnecessary or inconsistent decisions, but also that the introduction of new considerations supporting a preference for state forums should not serve as a basis for revitalization of this doctrine. Whatever the merits of such a preference - and it should be noted that the considerations supporting it call into question certain orthodox teaching about ripeness and state action ${ }^{50}$ - the issue raised is not one of abstention in any traditional sense, but rather one of whether and when plaintiffs should be required to exhaust their remedies under state law before they will, if ever, be heard to complain in federal court. Thus formulated, abstention emerges as an issue of exhaustion requirements and res judicata rules.

In fact, this has long been the case, at least in part. In Burford v. Sun Oil Co., ${ }^{51}$ an order of the Railroad Commission of Texas granting a permit to drill oil wells was attacked on state law and constitutional grounds. In a 5-4 decision, the Supreme Court held that the federal district court should have declined to exercise jurisdiction and dismissed the case "as a matter of sound equitable discretion." 52 Justice Black, writing for the Court, noted:

\footnotetext{
49227 U.S. 278 (1913); see pp. 1270-71 infra.

${ }^{50}$ See pp. 1270-7I infra.

51319 U.S. 315 (1943).

${ }^{52}$ Id. at 318, 334.
} 
In describing the relation of the Texas court to the Commission, no useful purpose will be served by attempting to label the court's position as legislative ... or judicial ...- suffice it to say that the Texas courts are working partners with the Railroad Commission in the business of creating a regulatory system for the oil industry. . . .

The State provides a unified method for the formation of policy and determination of cases by the Commission and by the state courts. The judicial review of the Commission's decisions in the state courts is expeditious and adequate. Conflicts in the interpretation of state law, dangerous to the success of state policies, are almost certain to result from the intervention of the lower federal courts. On the other hand, if the state procedure is followed from the Commission to the State Supreme Court, ultimate review of the federal questions is fully preserved here. ${ }^{53}$

Notably, Justice Frankfurter, the author of Pullman itself, dissented vigorously, arguing that the case depended upon "narrowly defined standards of law established by Texas for review of the orders of its Railroad Commission" which federal judges "are certainly not incompetent to apply." 54 Eight years later, in Alabama Public Service Commission v. Southern Railway, ${ }^{55}$ the Court relied on Burford in holding that the federal district court should have dismissed an action challenging the Commission's refusal to permit discontinuance of two intrastate train lines on the grounds that the refusal constituted a taking of property in violation of the fourteenth amendment. ${ }^{56}$ Justice Frankfurter, while concurring in the result on the grounds that the complaint failed to state a meritorious claim, strongly challenged the Court's abstention rationale:

The only reason for declining to entertain the suit is that it may well be more desirable as a matter of. State-Federal relations for the order of a State agency to be reviewed originally in the State lower court and not to be challenged in the first instance in a federal court. It is not for me to quarrel with the wisdom of such a policy. But Congress, in the constitutional exercise of its power to define the jurisdiction of the inferior federal courts, has decided otherwise. . . .

I regret my inability to make clear to the majority of this Court that its opinion is in flagrant contradiction with the unbroken course of decisions in this Court for seventy-five years. ${ }^{57}$

${ }^{53}$ Id. at $325^{-26}, 333^{-34}$.

${ }^{54} \mathrm{Id}$. at 342 .

5534 I U.S. 34 I ( 195 I).

${ }^{56} \mathrm{Id}$. at $349-50$.

${ }^{57} I d$. at $36 \mathrm{I}-62$ (Frankfurter, J., concurring) (emphasis added). 
Justice Frankfurter's frustration notwithstanding, Burford and Southern Railway are at least notable for making explicit the grounds for the foreclosure of federal jurisdiction. The Court's decision in these cases to enforce deference to state administrative and review procedures translates, as Justice Frankfurter suggested, into a policy decision that state courts are more appropriate forums for deciding such cases for their own sake and not because of any unclarity in the law or any lack of competence in the federal courts.

While Burford and Southern Railway are unusual cases in a number of respects, ${ }^{58}$ their theme of deference to states and their implicit conception of state courts as a component of an integral state unit has been echoed in more traditional abstention decisions. In Harrison v. NAACP, ${ }^{59}$ for example, the Supreme Court, in ordering abstention as to the constitutionality of Virginia statutes regulating and proscribing activities of organizations involved in litigation, emphasized:

All we hold is that these enactments should be exposed to state construction or limiting interpretation before the federal courts are asked to decide upon their constitutionality, so that federal judgment will be based on something that is a complete product of the State, the enactment as phrased by its legislature and as construed by its highest court..$^{60}$

The clearest statement of this "exhaustion" vision of federal question abstention was Chief Justice Burger's dissent in Wiscon$\sin$ v. Constantineau, ${ }^{61}$ where a state "posting" statute was attacked under the due process clause of the Federal Constitution. The Chief Justice suggested that the federal court should have abstained to permit the state courts to dispose of the claim under either the Wisconsin Constitution ${ }^{62}$ or the United States Constitution - a proposal which he properly characterized as requiring exhaustion of state judicial remedies. ${ }^{63}$ Although the

${ }^{58}$ Both Burford and Southern Railway were based on diversity as well as federal question jurisdiction and involved regulatory schemes in which state judicial review was concentrated in a single court. See HART \& WechsLer, supra note 20, at $994-96$.

${ }^{59} 360$ U.S. 167 (1959).

${ }^{60} I d$. at 178 (emphasis added).

${ }^{61} 400$ U.S. 433,439 (I97I) (Burger, C.J., dissenting).

${ }^{62} I d$. at 440 . The state constitutional provision was substantially equivalent to the federal one. Id. at 440 n.I. The majority opinion did not refer to Chief Justice Burger's argument concerning the state constitution. The majority applied ordinary Pullman principles, and not finding such ambiguity in the state statute as would permit a saving construction providing for notice and hearing, declined to require abstention. Id. at 439 .

${ }^{63} I d$. at 440 (Burger, C.J., dissenting). 
court has not explicitly adopted such a practice in the 1983 context, ${ }^{64}$ the implicit deference in a number of abstention cases, coupled with a trend in recent Supreme Court decisions to restrict the availability of federal court protection against state-inflicted injuries, ${ }^{65}$ suggests that the Chief Justice's vision requires closer scrutiny on its own terms. This is the task of the next Part.

\section{Exhaustion}

It has been considered well-settled law that a plaintiff may maintain a section 1983 action in federal court without regard to the availability of adequate state remedies. ${ }^{1}$ The decision in Monroe v. Pape ${ }^{2}$ clearly established this principle with respect to state judicial remedies. In finding that persons seeking damages for an unconstitutional search need not exhaust state tort remedies as a prerequisite to obtaining access to federal court, ${ }^{3}$ the Supreme Court explained that a purpose of section I983 was to make available a federal remedy "supplementary" to any that the state might provide, and, therefore, that "the latter need not be first sought and refused before the federal one is invoked." 4 In subsequent cases, the Court extended the Monroe "no-exhaustion" principle to section I 983 claims where the only available state remedy was an administrative one. ${ }^{5}$ In so doing,

${ }^{64}$ See Monroe v. Pape, 365 U.S. 167 (196r). See also Damico v. California, 389 U.S. 4 I6 (I967); McNeese v. Board of Educ., 373 U.S. 668 (1963).

${ }^{65}$ See Ingraham v. Wright, 45 U.S.L.W. 4364 (U.S. April I9, I977); Paul v. Davis, 424 U.S. 693 (1976).

${ }^{1}$ See, e.g., Chevigny, Section 1983 Jurisdiction: A Reply, 83 Harv. L. Rev. 1352 (1970); Note, Exhaustion of State Remedies Under the Civil Rights Act, 68 Colum. L. Rev. I201 (1968); Note, The Federal Injunction as a Remedy for Unconstitutional Police Conduct, 78 YALE L.J. I43 (1969). Each of the Supreme Court's major administrative exhaustion cases, however, dealt with a situation in which traditional principles would not have required exhaustion in any event. See Comment, Exhaustion of State Administrative Remedies in Section 1983 Cases, 4I U. ChI. L. Rev. 537, 544-47 (1974).

${ }^{2} 365$ U.S. 167 (196r).

${ }^{3} I d$. at 183 .

${ }^{4} I d$. Prior to Monroe, the Supreme Court had held that one seeking damages for denial of his right to vote by state officials did not have to exhaust his state judicial remedies before seeking redress in federal court, but it distinguished the possibility of requiring exhaustion of available administrative remedies. Lane $v$. Wilson, 307 U.S. 268, 274 (1939). The implication was that actions brought under \$ 1983 were governed by the general doctrine requiring administrative, but not judicial, exhaustion. See, e.g., Dove v. Parham, 282 F.2d 256 (8th Cir. 1960); Baron v. O'Sullivan, 258 F.2d 336 (3d Cir. 1958); Carson v. Warlick, 238 F.2d 724 (4th Cir. I956), cert. denied, 353 U.S. 910 (1957). But see Carter v. School Bd., I82 F.2d 53I (4th Cir. 1950).

${ }^{5}$ See Houghton v. Shafer, 392 U.S. 639 (1968); King v. Smith, 392 U.S. 309 
the Court appeared to act as if there were no significant differences between judicial and administrative remedies and paid no attention to the possible existence of reasons supporting administrative exhaustion not present in the judicial context; rather, the "supplementary" remedy doctrine was almost perfunctorily applied. ${ }^{6}$

The continued viability of the no-exhaustion rule, however, may be in some doubt. Judges and commentators have been extremely critical of the rule, particularly in the administrative context. ${ }^{7}$ Judge Friendly, for example, has strongly urged that section I 983 plaintiffs be required to exhaust adequate state administrative remedies as a precondition to access to the federal courts. ${ }^{8}$ Administrative exhaustion, which is the norm outside the context of section $1983,{ }^{9}$ is said to promote judicial economy and

(I968) ; Damico v. California, 389 U.S. 416 (1967) ; McNeese v. Board of Educ., 373 U.S. 668 (1963).

${ }^{6}$ In McNeese v. Board of Educ., 373 U.S. 668 ( 1963 ), the complaint of black plaintiffs for injunctive relief from alleged segregation in a public school system was dismissed by the district court because of their failure to exhaust administrative remedies. After detailing the remedies available to the plaintiffs under Illinois law, id. at 670-7I, Justice Douglas, writing for the Court, referred to the no-exhaustion language in Monroe and held that the dismissal had been improper, id. at $674-75$. The opinion left unclear whether the Court was relying on its finding that the state administrative remedy was inadequate or on an interpretation of Monroe making the adequacy of the state remedy irrelevant. Four years later, in Damico v. California, 389 U.S. $4 \mathrm{I} 6$ (I967), a challenge to a paternal absence requirement of a state welfare program, the Supreme Court in a per curiam opinion cited Monroe and McNeese without discussion for the proposition that state administrative remedies need not be exhausted prior to seeking relief under $\$ 1983$ :

In McNeese v. Board of Educ., ... noting that one of the purposes underlying the Civil Rights Act was "to provide a remedy in the federal courts supplementary to any remedy any State might have," ... we held that "relief under the Civil Rights Act may not be defeated because relief was not first sought under state law which provided [an administrative] remedy." .. . See Monroe v. Pape . . . .

Id. at 4I7 (brackets in original). See generally Note, Exhaustion of State Remedies Under the Civil Rights Act, 68 Colum. L. REv. I201 (1968) (criticizing the Damico decision for its treatment of the administrative exhaustion issue as if it were governed by settled law).

${ }^{7}$ Indeed, the Second Circuit has consistently resisted the conclusion that the Supreme Court decisions have in fact excluded all 1983 cases from an administrative exhaustion requirement. See Plano v. Baker, 504 F.2d 595 (2d Cir. 1974); Blanton v. State Univ., 489 F.2d 377, 384 (2d Cir. 1973); Goetz v. Ansell, 477 F.2d 636 (2d Cir. I973). In Eisen v. Eastman, 42I F.2d 560, 567-69 (2d Cir. 1969), cert. denied, 400 U.S. $84 \mathrm{I}$ (1970), Judge Friendly, pointing to the inadequacy of state remedies in each case, argued that McNeese, Damico, King, and Houghton established only the proposition that the exhaustion requirement is not to be applied woodenly.

${ }^{8}$ See H. Friendiy, Federal Jurisdiction: A General View ioo-oi (i973).

${ }^{9}$ See Myers v. Bethlehem Shipbuilding Corp., 303 U.S. 4I, 50-53 (1938); 
accurate dispute resolution by diverting litigation, at least initially, from the federal courts to specialized agencies; even if the plaintiff still seeks judicial relief after exhaustion, the federal court can benefit from the agency's expertise, its experience in construing its own statutes and regulations, and its ability to generate a detailed factual record. ${ }^{10}$ Moreover, in a federal system, there is an additional salient interest in permitting the states to design a set of institutions to carry out state functions, and in affording them a measure of independence consistent with the supremacy of federal law. ${ }^{11}$

Of course, to the extent that the calls for administrative exhaustion are predicated on concerns for federalism and the workload of the federal courts, the arguments ineluctably shade into arguments for judicial exhaustion as well. Although the forcefulness of the assertion of the no-judicial-exhaustion rule in Monroe may have led many commentators to focus their attention on administrative remedies, several commentators have suggested that in some cases plaintiffs should be compelled to bring their claims in state rather than federal court. ${ }^{12}$ Thus, Judge Aldisert has argued for the statutory imposition of a partial judicial exhaustion requirement. ${ }^{13}$ Other commentators, perhaps also seeking to avoid a head-on confrontation with Monroe, have suggested that the scope of the interests cognizable under section r 983 be redefined to exclude those interests adequately protected by existing state remedies. ${ }^{14}$ Such proposals would have the more ex-

Prentis v. Atlantic Coast Line, 2 I I U.S. 2 Io (I908); H. FrIENDLy, supra note 8, at roo. The application of the no-exhaustion rule to claims of violations of federal statutory rights which might be brought within the "Constitution and laws" language of $\S 1983$ is less clear. See P. Bator, P. Mishikin, D. Shapiro \& H. Wechsler, Hart \& Wechsler's The Federal Courts and the Federal System I249-50 (2d ed. I973).

${ }^{10}$ See Parisi v. Davidson, 405 U.S. 34, 37 (1972) ("the basic purpose of the exhaustion doctrine is to allow an administrative agency to perform functions within its special competence - to make a factual record, to apply its expertise, and to correct its own errors so as to moot judicial controversies"); McKart v. United States, 395 U.S. I85, I95 (I969); K. Davis, Administrative Law Treatise 382 (3d ed. I973); J. Landis, The Administrative Process I53 (i938).

${ }^{11}$ See pp. II 79-83 supra.

12 See, e.g., Monroe v. Pape, 365 U.S. I67, 202 (I96r) (Frankfurter, J., dissenting); Wisconsin v. Constantineau, 400 U.S. 433, 440 (I97I) (Burger, C.J., dissenting); Note, Limiting the Section 1983 Action in the Wake of Monroe v. Pape, 82 HaRv. L. Rev. I486 ( 1969 ).

${ }^{13}$ See Aldisert, Judicial Expansion of Federal Jurisdiction: A Federal Judge's Thoughts on Section 1983, Comity and the Federal Caseload, I973 LAw \& Soc. ORD. 557, 575-78.

${ }^{14}$ See, e.g., Shapo, Constitutional Tort: Monroe v. Pape and the Frontiers Beyond, 60 Nw. U.L. REv. 277 (I965). 
treme result not simply of postponing federal jurisdiction, but of denying a federal constitutional claim altogether.

Although formally continuing to adhere to the no-exhaustion rule, recent Supreme Court decisions have displayed some concern with its effects. In Preiser v. Rodriguez, ${ }^{15}$ the Court refused to allow prisoners challenging the fact or duration of their confinement to style their claims as 1983 actions and thus avoid the exhaustion requirement imposed by federal habeas corpus. ${ }^{16}$ In Gibson v. Berryhill, ${ }^{17}$ decided the same day, the Court, citing Younger $v$. Harris, ${ }^{18}$ suggested in dictum that administrative exhaustion might be appropriate where the state processes were adequate to protect the federal plaintiff's rights. ${ }^{19}$ More recently, the Supreme Court in the cases of Paul v. Davis ${ }^{20}$ and Ingraham v. Wright ${ }^{21}$ has demonstrated a significant attentiveness to the presence of adequate state judicial remedies in the adjudication of federal section 1983 claims. In Paul, plaintiff had brought a section r 983 damages action, contending that the defendant police chief had unjustifiably included the plaintiff's picture in a flyer which identified "active shoplifters" and which was distributed to approximately eight hundred local merchants. ${ }^{22}$ Although the Court's conclusion that the plaintiff had failed to state a claim cognizable under section 1983 formally turned on its finding that damage to reputation did not constitute the deprivation of any interests protected by the fourteenth amendment, ${ }^{23}$ the rhetoric of Justice Rehnquist's majority opinion emphasized the availability of a state tort action which duplicated the plaintiff's section 1983 allegations. ${ }^{24}$ The plaintiff, noted Justice Rehnquist, had stated "a classical claim for defamation" actionable in state court. ${ }^{25}$ To find that the police chief's alleged defamation constituted the invasion of a protected liberty interest would "almost necessarily" convert any tortious activity of a state officer acting under color of state law into a violation of the fourteenth

15 rr U.S. 475 (1973).

${ }^{16}$ Id . at 488-89. Exhaustion of state administrative and judicial remedies prior to a grant of federal habeas corpus is required by 28 U.S.C. $\$ 2254$ (b) (r970). See p. 1352 infra.

${ }^{17} 4$ I I U.S. 564 (1973).

18 40r U.S. 37 (r $97 \mathrm{r}$ ).

$194 \mathrm{II}$ U.S. at $573-75$.

${ }^{20}{ }_{424}$ U.S. 693 (1976).

${ }^{21} 45$ U.S.L.W. 4364 (U.S. April r9, r977).

22424 U.S. at 695.

${ }^{23}$ Id. at 699-710. See generally The Supreme Court, 1975 Term, 90 Harv. L. REv. 56, 86 (1976).

${ }^{24}$ See generally Shapiro, Mr. Justice Rehnquist: A Preliminary View, 90 Harv.

L. REv. 293, 324-28 (r976).

${ }^{25} 424$ U.S. at 697 . 
amendment. ${ }^{26}$ Rather, the Court leaned in the opposite direction, implying that state officer harms for which the state had provided tort remedies were not cognizable as federal section 1983 actions. Where a plaintiff's interest, wrote Justice Rehnquist, is "simply one of a number which the State may protect against injury by virtue of its tort law," state courts provide "a forum for the vindication of those interests by means of damage actions." 27

This nexus between the existence of adequate state judicial remedies and the availability of a section 1983 claim was more directly suggested in the decision this Term in Ingraham $v$. Wright. ${ }^{28}$ In Ingraham, the Court rejected individual damages actions and a class action for declaratory and injunctive relief filed on behalf of a group of Florida school children challenging the constitutionality of a state statute authorizing disciplinary corporal punishment. Plaintiffs had contended that the paddling of students as a means of maintaining school discipline constitutes cruel and unusual punishment in violation of the eighth amendment, and that even if paddling is constitutionally permissible the due process clause of the fourteenth amendment requires prior notice and an opportunity to be heard. ${ }^{29}$

Justice Powell prefaced his majority opinion ${ }^{30}$ with a separate section which discussed the role played by " $[\mathrm{t}]$ raditional common law concepts" in illuminating the cruel and unusual punishment and due process clauses. ${ }^{31}$ In a refrain that echoed throughout the opinion, Justice Powell found a common law background of historical and contemporary approval of reasonable corporal punishment. Where excessive or unreasonable force is used, "the educator in virtually all States is subject to possible civil and criminal liability." 32 Proceeding to plaintiffs' allegations, the Court denied the eighth amendment claim, finding that the proscription against cruel and unusual punishment was designed to protect only those persons convicted of crime. ${ }^{33}$ In declining to extend it to the paddling of children in the public schools, Justice Powell invoked the existence of the "legal constraints of the common law" to determine that since schoolchildren enjoy

\footnotetext{
${ }^{26} I d$. at 699.

${ }^{27} I d$. at $7 \mathrm{I} 2$.

${ }^{28} 45$ U.S.L.W. 4364 (U.S. April 19, 1977).

${ }^{29}$ Id. at $4365-66$.

${ }^{30}$ Justice Powell's opinion was joined by the Chief Justice and Justices Stewart, Blackmun, and Rehnquist.

${ }^{31} 45$ U.S.L.W. at 4366-67 (citing Powell v. Texas, 392 U.S. 5r4, 535 (Ig68)).

${ }^{32} 45$ U.S.L.W. at 4367 .

${ }^{33}$ Id.
} 
"significant safeguards" against official abuses which are unavailable to prisoners, they have "little need" for the protection afforded by the eighth amendment. ${ }^{34}$ Justice Powell relied even more explicitly on the existence of adequate common law remedies in disposing of the plaintiffs' procedural due process claim. Although the Court found that the "liberty" safeguarded by the fourteenth amendment was implicated by disciplinary corporal punishment, it held that traditional common law remedies are adequate to afford due process. ${ }^{35}$ At common law, Justice Powell noted, a teacher's privilege to discipline a student was limited to the administration of "moderate correction"; as long as the disciplinary punishment authorized by the state was within the scope of the common law privilege, he concluded, there was no deprivation of any of the "substantive rights" of the child. ${ }^{36}$ Moreover, there was no need for federal safeguards to protect the child from excessive punishments not privileged at common law since "[i]n those cases where severe punishment is contemplated, the available civil and criminal sanctions for abuse" adequately vindicate the rights of the child. ${ }^{37}$

Like Paul v. Davis, Ingraham may plausibly be interpreted as an attempt to define or limit the substantive rights protected by relatively open-ended constitutional provisions. Yet the re-

${ }^{34}$ Id. at 4369 .

The openness of the public school and its supervision by the community afford significant safeguards against the kinds of abuses from which the Eighth Amendment protects the prisoner. In virtually every community where corporal punishment is permitted in the schools, these safeguards are reinforced by the legal constraints of the common law. Id.

${ }^{35}$ Id.

${ }^{36}$ Id. at 437 I.

${ }^{37}$ Id. Justice White, in a dissenting opinion joined by Justices Brennan, Marshall, and Stevens, took issue with the Supreme Court's refusal to extend the protections of the eighth amendment beyond the claims of prisoners. Id. at 4373 . He argued that the proper inquiry should be "whether the purpose of the deprivation is among those ordinarily associated with punishment, such as retribution, rehabilitation, or deterrence," $i d$., and that the availability of state remedies should be considered irrelevant to a determination of the coverage of the eighth amendment, id. at 4374 .

The fact that a person may have a state-law cause of action against a public official who tortures him with a thumb screw for the commission of an antisocial act has nothing to do with the fact that such official conduct

is cruel and unusual punishment prohibited by the Eighth Amendment.

Id. Justice White also took issue with the majority's finding that common law remedies were adequate to protect the plaintiffs' recognized liberty interest, noting that not only was a student under Florida law barred from recovery when the teacher had acted in good faith, id. at 4375 , but also that the lawsuit occurs after the punishment has been imposed, id. at 4376. "The infliction of physical pain is final and irreparable; it cannot be undone in a subsequent proceeding." Id. 
peated emphasis and reliance in those cases on the existence of adequate state remedies may foreshadow the rise of an exhaustion of state remedies doctrine in the context of section 1983 actions. ${ }^{38}$

Any decision as to the appropriateness of state exhaustion must ultimately turn on one's view of the state itself and of its operations. Given a conception of government as a cluster of closely connected officers and institutions making the basic policy and budgetary decisions affecting the lives of the governed, the notion of state autonomy suggests that there is some inner core of government which must be shielded from outside review and correction. $^{39}$ To pierce that inner core is to threaten the autonomy and integrity of the state. With respect to section r 983 actions, the inquiry becomes whether state courts and other remedial agencies are so intimately related to the other branches of state government that failure to test assertedly unconstitutional conduct of state officers first in state forums according to state laws invades the inner workings of state government. Another way of approaching the same problem is to treat the state action issue as a matter of ripeness. Viewed from this perspective, the problem becomes one of determining when, giving the mechanisms established by a state for promulgating, applying, and testing a law or rule, the conduct of a state officer or institution may be considered sufficiently complete to support a constitutional claim of state action.

The prevailing view since Home Telephone \& Telegraph Co. v. City of Los Angeles, ${ }^{40}$ decided in I9I3, has been that a state

${ }^{38}$ See Tribe, Unraveling National League of Cities v. Usery: Affirmative Rights to Essential Government Services, 90 HARv. L. REv. I065, I100 n.135 (1977). See also Bonner v. Coughlin, 5I 7 F.2d I3II, I3I8-20 (7th Cir. I975), modified en banc, 545 F.2d 656 ( 7 th Cir. I976).

Only Justice Stevens took note of the connection between Paul and Ingraham. In his separate dissent in Ingraham, 45 U.S.L.W. at 4377 , he pointed out:

When only an invasion of a property interest is involved, there is a greater likelihood that a damage award will make a person completely whole than when an invasion of the individual's interest in freedom from bodily restraint and punishment has occurred. In the property context, therefore, frequently a postdeprivation state remedy may be all the process that the Fourteenth Amendment requires. It may also be true - although I do not express an opinion on the point - that an adequate state remedy for a defamation may satisfy the due process requirement when a State has impaired an individual's interest in his reputation. On that hypothesis, the Court's analysis today gives rise to the thought that Paul v. Davis ... may have been correctly decided on an incorrect rationale. Perhaps the Court will one day agree with Mr. Justice Brennan's appraisal of the importance of the constitutional interest at stake in Paul ... and nevertheless conclude that an adequate state remedy may prevent every state inflicted injury to a person's reputation from violating 42 U.S.C. $\S$ I 983.

${ }^{39}$ See National League of Cities v. Usery, 426 U.S. 833 (1976); Tribe, supra note 38 , at 1070-72; pp. II 79-83 supra.

${ }^{40} 227$ U.S. 278 ( 1913 ). 
court decision as to the legality of challenged conduct under state law is not a necessary predicate to its challenge as "state action" in violation of the Constitution. ${ }^{41}$ The Home Telephone interpretation of state action draws support from the legislative history of the fourteenth amendment and from an examination of the general concerns of the Reconstruction Congress. ${ }^{42}$ As Chief Justice White's opinion for the unanimous Court in Home Telephone suggested, "the Amendment contemplates the possibility of state officers abusing the powers lawfully conferred upon them," and was intended to apply to such actions. ${ }^{43}$ Moreover, once the dispute has moved to a stage where a judicial remedy is required, the notion that the constitutional deprivation is in some sense "incomplete" becomes somewhat attenuated; while it may be that state courts, acting under state law, will provide an adequate remedy, the fact is that the particular defendants' role has ended and resort to a wholly separate unit of the state government is necessary to undo the harm that has been caused.

The effect of creating a state judicial exhaustion requirement would be at least to duplicate the burdens and costs involved in abstention in cases where there is no unclear state law claim. ${ }^{44}$ In every case in which the state court might provide an adequate remedy, the plaintiff would be forced to resort to that forum initially. At best, he might later resort to the federal courts to raise his constitutional claim if an adequate remedy under state law were not forthcoming; ${ }^{45}$ at worst - and considerations of respect for state courts as well as of judicial economy might support this result - he could be barred from federal relitigation under the doctrines of res judicata. ${ }^{46}$ In either case, the forum choice secured for 1983 claims would be substantially undermined without a clear statement of any intent to do so by Congress and with little justification in policy terms.

This is not to say that the state's interest in conducting its affairs and correcting its officers, free from federal interference, is not a significant one. But the cases where the displacements of state authority occasioned by the federal courts are most substantial - the "public law" actions discussed in Part III ${ }^{47}$ -

${ }^{41}$ See pp. I $66-67$ supra.

42 See pp. I I 4 I-56 supra.

43227 U.S. at 288.

${ }^{44}$ See pp. I254-57 supra.

${ }^{45} C f$. England v. Louisana State Bd. of Medical Examiners, 375 U.S. 4II (1964) (procedure for reserving federal claims for federal court determination in absention cases).

${ }^{46}$ See Bacon v. Rutland R.R., 232 U.S. I34, I38 (I9I4). See generally Part VII, pp. I330-60 infra.

${ }^{47}$ See pp. 1227-50 supra. 
are precisely the cases where exhaustion would be least appropriate. However adequate a state remedy may appear in theory, these are the cases where the federal judiciary's distance from local government operations and its insulation from majoritarian pressures emerge as most critical advantages, rendering any assumption of parity less persuasive. ${ }^{48}$ Were frequency of federal interventions the sole factor in determining intrusiveness, one might well argue that claims which appear cognizable as state law torts ought be left, at least initially, to the state courts. ${ }^{49}$ But because "intrusiveness" seems more likely to respond to the type of case than to any numerical calculus, concerns with minimizing intrusion provide weak support for the imposition of a judicial exhaustion requirement in cases which do not themselves give rise to serious interferences. And even if they did, the basic point remains that the fourteenth amendment was intended as a limit on the autonomy of states, with jurisdiction granted to the federal courts to give effect to this limit. ${ }^{50}$

Administrative exhaustion in the section I983 context presents a more difficult case. First, many of the traditional justifications for administrative exhaustion - agency expertise, judicial economy, consistency in the application of a regulatory scheme apply as well in the section 1983 context. ${ }^{51}$ Second, administrative exhaustion poses no threat that resort to a federal court will be foreclosed, since principles of res judicata do not attach to the agency's determinations. ${ }^{52}$ Third, the notion of ripeness or state action as a bar to initial assertion of a section r983 claim in federal court has greater appeal where the alternative is an administrative determination. Agencies may often be created to "fine tune" the application of statutory mandates or general standards to particular cases. To perform this function, procedures are established within the agency to govern individual complaints of unfair treatment. Where this is true, the view that the action of any single official should not give rise to a constitutional claim until other officials within that agency have had the opportunity to review the claim - thus allowing the particular agency to perform fully one of the functions for which it was established - begins to make a good deal of sense.

\footnotetext{
${ }^{48}$ See generally Neuborne, The Myth of Parity, go Harv. L. Rev. I I05 (1977).

${ }^{49}$ See Note, supra note 12 , at $1487,1494-98,1501-04$ (arguing that cases of individual deprivations should be brought in state court).

${ }^{50}$ See pp. I1 44-46 supra.

${ }^{51}$ See pp. 1265-66 \& note Io supra; H. FRIENDLY, supra note 8 , at 100-0I; Comment, supra note $\mathrm{I}$, at $540-42$.

${ }^{52}$ See Prentis v. Atlantic Coast Line, 2 I I U.S. 2 10, 230 (1908); Comment, supra note I, at $555 \& \mathrm{n} .68$.
} 
If administrative exhaustion seems to make some sense in abstract terms, the next step is to suggest criteria which will allow courts to isolate those cases in which exhaustion would in fact be appropriate. While it is difficult to develop meaningful concrete criteria solely by reference to concerns for completeness or ripeness, developed principles of administrative law for determining when exhaustion should be considered inappropriate seem to track, as well as any criteria could, those cases where the individual's dispute with the state should be considered ripe for judicial determination..$^{53}$ Thus, exhaustion should not be required where further recourse to the administrative process would create the likelihood of irreparable harm, ${ }^{54}$ where the litigant would be unable to obtain a remedy from the agency that would vindicate the asserted right, ${ }^{55}$ or where his objection goes to the constitutionality of the process of decisionmaking in the agency. ${ }^{56}$ In none of these cases would exhaustion serve interests in judicial economy or promote the utilization of agency expertise; in none of them would the agency be called upon to perform a function of "fine tuning" the application of standards and procedures to ensure fair and constitutional treatment of the individual.

Properly structured, an administrative exhaustion requirement in the context of 1983 actions would have limited application. ${ }^{57}$

${ }^{53}$ See generally L. Jaffe, Judicial Control of Admintstrative Action 42640 ( 1965 ).

${ }^{54}$ According to Professor Jaffe, "the question is ... whether an immediate appeal is necessary to give realistic protection to the claimed right." Id. at 429 ; see, e.g., Smith v. Illinois Bell Tel. Co., 270 U.S. 587, 591-92 (1926).

${ }^{55}$ See Ray v. Fritz, 468 F.2d 586 (2d Cir. I972); Jaffe, supra note 53, at 42627. McNeese v. Board of Educ., 373 U.S. 668 (1963), fits within this category. Under Illinois law, the Superintendant of Public Education was empowered to grant only two sorts of relief - upon a finding of discrimination, he could withhold state aid and request that the state attorney general seek an injunction. Id. at 675. The Court found that withholding aid was "at best an indirect sanction," id. at 676 , and that it would be anomalous if a federal suit were delayed by a state remedy that would at most result in a state court action, id. at 675 .

${ }^{56}$ This exception would cover most due process objections to the composition, objectivity, and procedures of the state agency. Gibson v. Berryhill, 4 II U.S. 564 (1973), is a clear example of such a case. In Gibson, a group of optometrists alleged that the state board of optometry was disqualified from holding proceedings to revoke their licenses both because its members had a pecuniary interest in the outcome and because it had prejudged the issues in the license revocation proceedings by bringing a state court action against the optometrists on the same grounds. Id. at $57 \mathrm{I}$. The Supreme Court, noting that the federal courts were divided on the permissibility of combining prosecutorial and adjudicative functions, left the question open, id. at 578-79 \& n.I $;$; see Withrow v. Larkin, 4 I 7 U.S. 35 (1975) (upholding constitutionality of combination of functions against due process challenge), and held that the bias resulting from a pecuniary interest made the hearing before the state board an inadequate remedy, 4 II U.S. at 579.

${ }^{57}$ In cases where it would apply, the question arises whether judicial review 
Indeed, in all the cases in which the Supreme Court has articulated its no-exhaustion rule, the state administrative remedies were sufficiently inadequate that exhaustion would not have been appropriate in any event. ${ }^{58}$ But even a limited exhaustion rule would not only serve the state's interest in controlling its affairs and correcting its officials but could also increase state sensitivity to federal rights and encourage implementation of adequate procedural responses to constitutional objections.

\section{The Younger Doctrine}

In $197 \mathrm{I}$, in Younger v. Harris ${ }^{1}$ and its companion cases, ${ }^{2}$ the Supreme Court enunciated a doctrine of federal judicial restraint with profound procedural and substantive implications. Younger held that, in the absence of extraordinary circumstances, a federal court is precluded from enjoining a pending state criminal prosecution. ${ }^{3}$ To justify making an exception to the guarantee of a federal forum provided in section 1983 and enshrined in

by the state courts of the agency determination should be required. See Burford v. Sun Oil Co., 319 U.S. 315 (1943); Alabama Pub. Serv. Comm'n v. Southern Ry., 34I U.S. 34I (I95I); pp. I26I-63 supra. But even if one accepts the view that the state courts are the "working partners" of the agencies in such cases, Burford v. Sun Oil Co., 319 U.S. at 326 , the fact that res judicata effect would attach to the determinations of the state court, in contrast to the state agency, compare Bacon v. Rutland R.R., 232 U.S. I34, I38 (1914), with Prentis v. Atlantic Coast Line, 2 II U.S. 2 I0, 230 (1908), militates against a requirement of judicial review.

${ }^{58}$ See Eisen v. Eastman, 42 I F.2d 560, 569 (2d Cir. 1969) (Friendly, J.), cert. denied, 400 U.S. 84I (1970); Comment, supra note I, at 544-47.

${ }^{1} 401$ U.S. 37 (1971).

${ }^{2}$ Samuels v. Mackell, $40 \mathrm{I}$ U.S. 66 (I97I); Boyle v. Landry, $40 \mathrm{I}$ U.S. 77 (1971); Perez v. Ledesma, 40 I U.S. 82 (I97I) ; Dyson v. Stein, 40 I U.S. 200 (I97I); Byrne v. Karalexis, 40I U.S. 216 (I97I). In addition, 21 cases were summarily disposed of in light of Younger. See $40 \mathrm{I}$ U.S. at $948-90$. The Younger cases have been the subject of voluminous commentary. See, e.g., Wechsler, Federal Courts, State Criminal Law and the First Amendment, 49 N.Y.U. L. Rev. 740 (1974); Whitten, Federal Declaratory and Injunctive Interference with State Court Proceedings: The Supreme Court and the Limits of Judicial Discretion, 53 N.C.L. REv. 59I (1975); Zeigler, An Accommodation of the Younger Doctrine and the Duty of the Federal Courts to Enforce Constitutional Safeguards in the State Criminal Process, 125 U. PA. L. Rev. 266 (1976); Comment, Post-Younger Excesses in the Doctrine of Equitable Restraint: A Critical Analysis, 1976 Duke L.J. 523; The Supreme Court, 1970 Term, 85 HaRv. L. REv. 38, 30I-15 (197I); The Supreme Court, 1974 Term, 89 HaRv. L. Rev. 47, 151-69 (1975); Note, Federal Relief Against Threatened State Prosecutions: The Implications of Younger, Lake Carriers and Roe, 48 N.Y.U. L. Rev. 965 (1973). For a pre-Younger discussion of some of the problems addressed in the text, see Maraist, Federal Injunctive Relief Against State Court Proceedings: The Significance of Dombrowski, 48 TEx. L. Rev. 535 (1970).

${ }^{3} 4$ OI U.S. at $53-54$. 
Monroe v. Pape, ${ }^{4}$ the Court relied on traditional principles of equity jurisprudence, the notion of federal-state comity, and the values underlying what Justice Black called "Our Federalism." 5 In subsequent decisions, those values have provided a fulcrum for extending the Younger holding and altering its emphasis. The result has been a powerful and perplexing tool for channelling constitutional litigation into state forums and curtailing the equitable authority of the federal courts. This Part will explore and evaluate that tool, the circumstances in which it is applied, and the balance it strikes between federalism values and the concerns implicit in section I 983 's provision of a federal cause of action and a federal forum for constitutional cases.

\section{A. The February Decisions}

I. The Key Cases. - Harris, the plaintiff in Younger, had been indicted for violating the California Criminal Syndicalism Act. ${ }^{6}$ He sought a federal injunction to halt the pending prosecution on grounds that the statute was unconstitutional on its face. ${ }^{7}$ The claims of three coplaintiffs - none of them targets of state proceedings - were dismissed as too "imaginary" or "speculative." 8

In his opinion for the Court, Justice Black asserted that Congress had always manifested "a desire to permit state courts to try state cases free from interference by federal courts." ${ }^{9} \mathrm{He}$ discussed three concerns underlying "this longstanding public policy." 10 First was "the basic doctrine ... that courts of equity should not act, and particularly should not act to restrain a criminal prosecution, when the moving party has an adequate remedy at law and will not suffer irreparable injury if denied equitable relief." 11 Second was "the notion of 'comity,' that is, a proper respect for state functions . . . and a continuance of the

${ }^{4} 365$ U.S. I67 (I96I).

${ }^{5} 401$ U.S. at $43-44$.

${ }^{6} I d$. at 38 . The statute had been upheld in Whitney v. California, 274 U.S. 357 (1927) - a case that was overruled in Brandenburg v. Ohio, 395 U.S. 444, 449 (1969).

${ }^{7} 40$ I U.S. at $38-39$.

${ }^{8} I d$. at $4 \mathrm{I}^{-42}$. Two of the coplaintiffs were members of the Progressive Labor Party who claimed the prosecution of Harris inhibited their advocacy of political change. The third was a college professor who alleged that he feared prosecution under the challenged statute for teaching the theories of Karl Marx. Justice Black observed that a federal suit to stop a pending state prosecution "is a serious matter" and that the three were not "appropriate plaintiffs" in such a case. Id. at $4 I-42$.

${ }^{9} I d$. at 43 .

${ }^{10} I d$.

${ }^{11} I d$. at $43-44$. 
belief that the National Government will fare best if the States and their institutions are left free to perform their separate functions in their separate ways." " 12 This shades into Justice Black's third concern, the concept of "Our Federalism," which, he wrote, requires sensitivity to both state and national governments and a system in which "the National Government, anxious though it may be to vindicate and protect federal rights and federal interests, always endeavors to do so in ways that will not unduly interfere with the legitimate activities of the States." ${ }^{13}$ Accordingly, Justice Black continued, "the normal thing to do when federal courts are asked to enjoin pending proceedings in state courts is not to issue such injunctions." 14

The lower court that awarded relief to Harris had relied heavily on the Warren Court decision in Dombrowski v. Pfister, ${ }^{15}$ which had authorized a federal injunction to block threatened state prosecutions against civil rights activists in Louisiana. ${ }^{16}$ Dombrowski had appeared to rest on alternative grounds. First, the plaintiffs had alleged a pattern of prosecutorial bad faith and harassment that distinguished their situations from that of a defendant in a normal criminal prosecution brought in the hope of securing a valid conviction. ${ }^{17}$ Second, the Court suggested that the facial overbreadth of the statutes involved in Dombrow$s k i$ - their chilling effect on the exercise of first amendment rights - justified special federal vigilance. ${ }^{18}$

In Younger, Justice Black said that Dombrowski had been misunderstood by the lower court and argued that that decision had turned only upon the allegations of prosecutorial bad faith. ${ }^{19}$ $\mathrm{He}$ asserted that the existence of a chilling effect on first amendment freedoms, alone, is insufficient to justify federal intervention with state criminal processes,${ }^{20}$ and that facial adjudication followed by broad injunctions is "fundamentally at odds with the function of the federal courts." ${ }^{21}$

While a mere showing of facial invalidity would be insufficient

12 Id. at 44 .

${ }^{13}$ Id.

${ }^{14} I d$. at 45 .

${ }^{15} 380$ U.S. 479 (1965). The lower court opinion in Younger considered the Dombrowski case. 28I F. Supp. 507, 510-I I (C.D. Cal. I968) (three-judge court).

${ }^{16}$ See 380 U.S. $479,497-98$ (1965).

${ }^{17}$ Id. at 482,490 .

${ }^{18} I d$. at 486 , 490-91. On first amendment overbreadth, see generally Note, The First Amendment Overbreadth Doctrine, 83 HaRv. L. REv. 844 (I970).

${ }^{19} 40 \mathrm{I}$ U.S. at 50 . Justice Black conceded that there were "some statements in the Dombrowski opinion that would seem to support" a contrary reading, but argued that such statements were "unnecessary to the decision." Id.

${ }^{20}$ Id. at $5 \mathrm{I}-52$.

${ }^{21}$ Id. at 52 . 
to support an injunction, Justice Black conceded that there might be "extraordinary circumstances in which the necessary irreparable injury can be shown even in the absence of the usual prerequisites of bad faith and harassment." ${ }^{22}$ Among them, he said, would be statutes "flagrantly and patently violative of express constitutional prohibitions in every clause, sentence and paragraph ...." ${ }^{23}$

Among the companion cases, Samuels v. Mackell ${ }^{24}$ held that the propriety of federal declaratory relief when the federal court plaintiff is the target of a pending state prosecution should be measured by the standards set forth in Younger for deciding the availability of injunctive relief. ${ }^{25}$ Writing again for the Court, Justice Black reasoned that "ordinarily a declaratory judgment will result in precisely the same interference with and disruption of state proceedings that the long-standing policy limiting injunctions was designed to avoid." 26 He noted that in some circumstances a declaratory judgment could serve as the predicate for a later injunction, and that, even if it did not, it would have the effect of removing the constitutional question from the state court system. ${ }^{27}$

Boyle v. Landry ${ }^{28}$ was a challenge by black residents of Chicago to a number of statutes and ordinances which they claimed were being used to harass and intimidate blacks in the exercise of their first amendment rights. ${ }^{29}$ The question on appeal to the Supreme Court was limited to the propriety of the district court order declaring invalid one subsection of an "intimidation" statute and enjoining state officials from enforcing it. ${ }^{30}$ No

${ }^{22} I d$. at 53 .

${ }^{23} I d$. (quoting Watson v. Buck, 313 U.S. 387,402 (I94I)).

24 40r U.S. 66 (I97I).

${ }^{25}$ Id. at 73 .

${ }^{26} I d$. at 72 .

${ }^{27}$ Id. The Court relied heavily on Great Lakes Dredge \& Dock Co. v. Huffman, 3 I 9 U.S. 293 ( I943), which had denied declaratory relief against a state unemployment compensation law in somewhat analogous fashion. The Great Lakes opinion observed that a federal injunction against enforcement of the statute would have been barred under the Tax Injunction Act, 28 U.S.C. $\$$ I34I (1970), in the absence of a showing that the state provided no adequate remedy. Accordingly, the Great Lakes Court asserted, declaratory relief should likewise be withheld because it would "in every practical sense operate to suspend collection of the state taxes." 319 U.S. at 299.

28 40I U.S. 77 (1971).

${ }^{29} I d$. at 78 .

${ }^{30} I d$. at 79-80. The district court held the provision void for overbreadth. Landry v. Daley, 280 F. Supp. 938, 96r-67 (N.D. Ill. I 968 ) (three-judge court), rev'd sub nom. Boyle v. Landry, 401 U.S. 77 (197I). 
plaintiffs faced charges under that subsection, ${ }^{31}$ although several were being prosecuted under statutes not before the Court. ${ }^{32}$

In his opinion for the Court, Justice Black characterized the case as follows: "[I]t appears from the allegations that those who originally brought this suit made a search of state statutes and city ordinances with a view to picking out certain ones that they thought might possibly be used . . . for bad-faith prosecutions against them." 33 The Court found that the plaintiffs had failed to show they would suffer irreparable injury if the state were left free to prosecute them under the statute. Accordingly, they were not entitled to relief.

Two aspects of the case are noteworthy. First, the Court used the irreparable harm test in a way that foreshadows a kind of "Catch-22" for plaintiffs. " If Younger imposes an extra-heavy burden on persons seeking federal relief when state proceedings are pending and a variant of the irreparable harm test or a strictly applied ripeness standard restricts relief before charges have been filed, there will be little time during which the doors of the federal courthouse are open. Second, the Court showed a willingness to analyze plaintiffs' complaints in discrete pieces - to require a particularized showing of irreparable harm with respect to each statute challenged rather than considering the aggregate allegations of prosecutorial bad faith. ${ }^{35}$

2. The Background. - The Court enunciated its I97I decisions with some fanfare. In addition to six full opinions several of them containing rather broad language - twenty-one cases were summarily disposed of in light of Younger and the total effect was such as to suggest that the Court felt it had done something of importance. ${ }^{36}$ Yet the Younger opinion also seems steeped in history and precedent. It quotes case after case asserting the general rule that federal courts should exercise restraint when asked to interfere with state criminal processes ${ }^{37}$ and, with the exception of the limiting construction given to Dombrowski, purports simply to be reiterating and applying old adages. Indeed, Justice Brennan, author of the Dombrowski opinion, concurred in Younger. ${ }^{38}$ This blend of the extraordinary and the commonplace stems in part from ambiguities in the prior case law and in Younger itself.

${ }^{31} 40 \mathrm{I}$ U.S. at $80-8 \mathrm{I}$.

${ }^{33}$ Id. at $8 \mathrm{I}$.

${ }^{34} \mathrm{~A}$ discussion of this problem begins at p. 1292 infra.

${ }^{35}$ See note 245 infra for a more explicit and recent example of this tendency.

${ }^{36}$ See note 2 supra.

${ }^{37} \mathrm{See} 40 \mathrm{I}$ U.S. at $45-46$.

${ }^{38}$ Id. at $56-58$. 
The proliferation in the late nineteenth and early twentieth centuries of state schemes for regulating business led to the rise of substantive due process doctrines and with them to an era of judicial activism. ${ }^{39}$ Prior to that, the historic reluctance of equity to entrench on the criminal process ${ }^{40}$ had combined with statutory ${ }^{41}$ and constitutional restraints ${ }^{42}$ to create a general rule against federal interference. The 1908 decision in Ex parte Young ${ }^{43}$ made it clear that these restraints could be circumvented and that federal courts had the power to decide the validity of state statutes and enjoin their enforcement - at least where no proceedings were yet pending. ${ }^{44}$

The holding in Young was cast as an exception to a broad rule against federal relief, a rule that required plaintiffs to demonstrate threatened harms and burdens greater than those attendant to defending any criminal prosecution. ${ }^{45}$ This "defense plus"

${ }^{39} \mathrm{See}$ G. Gunther, Cases and Materials on Constitutional Law 557-76 (9th ed. I975); Warren, Federal and State Court Interference, 43 HaRv. L. Rev. $345,373-74$ (1930); Whitten, supra note 2 , at 629-30.

${ }^{40}$ See Whitten, supra note 2, at 597-600; Developments in the Law-Injunctions, 78 HARv. L. REv. 994, 1024 (1965) [hereinafter cited as Injunctions]. Equity's traditional reluctance stemmed from a number of intersecting factors. Among them: the historic absence in criminal proceedings of property interests of the kind generally protected by equity; the dominance in criminal cases of issues of fact within the province of the jury; and equity's dependence - for its efficacy and at times for its political survival - on remaining a supplemental forum and therefore its need to avoid defining the burden of defending against any criminal prosecution as an irreparable harm sufficient to support intervention.

See generally O. Fiss, Injunctions (1972); Injunctions, supra, at 1004-13.

${ }^{41}$ See Anti-Injunction Act, 28 U.S.C. $\$ 2283$ (1970). First enacted in 1793 , Act of March 2, I 793, ch. 22, § 5, I Stat. 335, the Act prohibits federal courts from enjoining state proceedings in most circumstances. See generally Mitchum v. Foster, 407 U.S. 225 (1972).

42 The major constitutional restraint, of course, was the eleventh amendment. See pp. I165-67 supra.

43209 U.S. I23 (I908).

${ }^{44} \mathrm{Id}$. at $\mathrm{I} 6 \mathrm{I}-62$.

${ }^{45} I d$. at $161-63$. The Young Court found grounds for making an exception to general rules counseling restraint in the fact that the challenged rate legislation contained penalties so harsh that they effectively prevented the defendant railroads from attacking the rate levels by violating them and risking conviction. While the holding was limited to cases of threatened state proceedings, the Court was aware of the controversial implications of its decision and attempted to soothe potential detractors, id. at 166. See Hutcheson, A Case for Three Judges, 47 Harv. L. Rev. 795, 803-IO (I934). See generally P. Bator, P. Mishkin, D. Shapiro \& H. Wechsler, Hart \& Wechsler's The Federal Courts and the Federal System 965-79 (2d ed. 1973) [hereinafter cited as Hart \& Wechsler]. Congress responded in a limited fashion by passing the Three-Judge Court Act, Act of June 18 , I910, ch. $309, \S 17,36$ Stat. 557, and subsequent amendments increasing the scope of the Act. See generally Perez v. Ledesma, 40I U.S. 82, 107-10 (I97I) (Brennan, J., concurring and dissenting); HART \& WECHSLER, supra, at $967-75$. The three-judge court statutes were overhauled last year and the role of 
burden, the Court suggested in Young and later cases, could be met where the would-be federal plaintiff was faced with a danger of multiple prosecutions or harassment, ${ }^{46}$ where he faced damages from the threatened prosecution of an employee or business associate who might decline to violate and test an arguably invalid law, ${ }^{47}$ or where he faced a prosecution brought in bad faith. ${ }^{48}$ These principles were fairly elastic, and it has been argued with some force that exceptions had all but swallowed up the rule in the pre-Younger years. ${ }^{49}$ Certainly the Court's litany of restraint did not serve as a firm ban on federal interference. Rather, it was an intermittent obstacle that seemed sometimes to vary with the judicial predilections and substantive doctrines of the day. Hence, concern with equitable restraint increased with the demise of substantive due process and then waned somewhat as the focus of constitutional law shifted from economic regulation to individual liberties. ${ }^{50}$

In the civil rights area - the one most relevant to Younger principles of equitable restraint seem to have been least clearly established. The Court's major enunciation of the need for restraint in first amendment cases was the 1943 decision in Douglas $v$. City of Jeannette. ${ }^{51}$ Although that case contains a broad call for federal restraint, ${ }^{52}$ the issue it actually addressed was relatively narrow. Plaintiffs, Jehovah's Witnesses, sought declaratory and injunctive relief against prosecutions under an antisolicitation

such courts substantially curtailed - primarily in response to increasing docket loads. See Pub. L. No. 94-38I, 90 Stat. i ir9 (1976); P. Bator, P. Mishikin, D. Shapiro \& H. Wechsler, The Federal Courts and the Federal System I53-55 (2d ed. Supp. 1977).

${ }^{46}$ See, e.g., Ex parte Young, 209 U.S. I23, 163-64 (1908) (problem of severe or cumulative penalties); Hague v. CIO, 307 U.S. 496, 5 16 (1939) (risk of multiple prosecutions and official actions in bad faith); Dombrowski v. Pfister, 380 U.S. 479, 485-89 (1965) (same); Beal v. Missouri Pac. R.R., 312 U.S. 45 (I94I) (injunction denied after state attorney general agreed to prosecute only a single test case). Multiple prosecutions may suggest the appropriateness of interim equitable relief, see p. 1305 infra.

${ }^{47}$ See Whitten, supra note 2, at 602-03 \& nn.44-45. See also Ex parte Young, 209 U.S. I23, 163-64 (1908).

${ }^{48}$ Cf. Beal v. Missouri Pac. R.R., 3 I 2 U.S. 45, 49 (I94I) ("No citizen . . . is immune from prosecution, in good faith, for his alleged criminal acts") ; Douglas v. City of Jeannette, 319 U.S. I57, I64 (I943) (same). The bad faith exception notion is explicitly set forth in Younger v. Harris, 40I U.S. 37, 54 (I97I).

${ }^{49}$ See generally Wechsler, supra note 2 ; see also Zeigler, supra note 2, at 26983.

${ }^{50}$ See Zeigler, supra note 2 , at 272-78; Whitten, supra note 2 , at 632-33.

513 I9 U.S. 157 ( 1943 ).

52 "[C]ourts of equity in the exercise of their discretionary powers should . . . [refuse] to interfere with or embarrass threatened proceedings in state courts save in those exceptional cases which call for the interposition of a court of equity to prevent irreparable injury which is clear and imminent ...." Id. at 163 . 
ordinance. ${ }^{53}$ The Court denied all relief. ${ }^{54}$ However, another decision handed down the same day had reversed a state court conviction under the challenged statute and declared it unconstitutional. $^{55}$ As a result, although by a different route, the plaintiffs had obtained the constitutional ruling they sought. Absent some indication that injunctive relief was necessary in addition ${ }^{56}$ dismissal was a clearly proper and easy result to reach.

On these grounds, Douglas is readily distinguishable from the situation posed in the 1971 cases. Certainly it did not compel the Younger result. ${ }^{57}$ Indeed, like the cases in other areas which it echoed, the apparently strict standard set forth in Douglas was from time to time ignored altogether in opinions that reached the merits of anticipatory challenges to state criminal statutes. ${ }^{58}$

Younger, against this background, does represent something of a departure both because of the breadth of its language and because it specifically confronted the special problems posed when a plaintiff seeks federal relief against a pending prosecution. With rare exceptions, prior cases either ignored the distinction between pending and nonpending prosecutions or considered it in dicta. ${ }^{59}$ Younger, in concert with subsequent cases, built

${ }^{53} I d$. at $159-60$.

${ }^{54} I d$. at 166.

${ }^{55}$ Murdock v. Pennsylvania, 3 I9 U.S. 105 (1943).

56 The Court observed in Douglas that there was "no allegation ... and no proof that [the state authorities] would not, nor can we assume that they will not, acquiesce in the decision of this Court holding the challenged ordinance unconstitutional as applied .... 319 U.S. at 165 .

${ }^{57}$ Similarly, lower courts were able to escape Douglas or recognize modifications to it in cases challenging segregation laws in the South. See, e.g., Bush v. Orleans Parish School Bd., I94 F. Supp. I82 (E.D. La. I96I) (three-judge court), aff'd per curiam sub nom. Gremillion v. United States, 368 U.S. I I (I96I). Further, Douglas obviously proved no obstacle to the Supreme Court decision in Dombrowski v. Pfister, 380 U.S. 479 (1965).

${ }^{58}$ For example, only six weeks after Douglas was decided, the Court struck down flag salute statutes without even considering principles of equitable restraint. West Virginia State Bd. of Educ. v. Barnette, 3I9 U.S. 624 (I943). See generally Wechsler, supra note 2 , at $8 \mathrm{I}_{3}-33$.

59 Dicta in Ex parte Young, 209 U.S. I23 (I908), asserted that "the Federal court cannot, of course, interfere in a case where the proceedings were already pending in a state court." Id. at I62. Hague v. CIO, 307 U.S. 496 ( I939), approved injunctions against official harassment and the enforcement of two city ordinances without considering whether there were pending state proceedings. In Cline v. Frink Dairy Co., 274 U.S. 445 (1927), the Court did focus on the presence of a pending proceeding. It sought to accommodate the Ex parte Young dicta by upholding a declaration that the state antitrust statute at issue was unconstitutional and an injunction against future enforcement, but reversing that portion of the injunction that was directed at the pending prosecution. Id. at $452-53,466$. While it manifests an awareness that pending proceedings may pose particular problems, nothing in Cline suggests that the applicability of general principles of restraint should be keyed to the pendency of state charges. Indeed, relief was 
on that distinction and created what amounts to a categorical rule against certain kinds of federal interference.

\section{B. Possible Justifications}

Before analyzing the subsequent development of the Younger doctrine, it is useful to pause on the I97 I decisions and the intersecting concerns and values on which they appear to be premised. This is particularly important in light of a recent tendency to cite Younger and progeny uncritically for the proposition that federal courts should exercise restraint whenever they are considering constitutional claims against state actors. ${ }^{60}$ That tendency obscures the strengths and also the limits of the Court's revivified doctrine of equitable restraint.

The I97I decisions considered what this Part refers to as the paradigm Younger fact situation: A plaintiff already enmeshed in state criminal proceedings seeks from the federal courts a declaration that the state law under which he is being prosecuted is invalid and an injunction halting his prosecution. The Younger Court's response to this situation was to establish a categorical rule against federal interference with pending state criminal proceedings. This rule - like the equity, comity, and federalism trilogy said to support it ${ }^{61}$ - may be seen as a product of two interrelated clusters of concerns and preferences.

I. Forum Allocation Preferences. - Younger may be viewed primarily as an effort to allocate constitutional litigation among competing forums. The central problem then becomes which of two remedies in two available court systems is appropriate for a single constitutional problem. Younger can be seen as a refusal to authorize a coercive remedy in the civil side of the federal courts when an equivalent noncoercive remedy is available from the criminal division of the state courts. In this mold, it expresses any or all of three preferences.

(a) The Preference for Noncoercive Forms of Relief. Equity has long been concerned with minimizing the use of coercive, disruptive remedies. ${ }^{62}$ The refusal to issue an injunc-

awarded in Cline and the Court's modification of the decree would most likely have little symbolic - and no practical - significance.

${ }^{60}$ See, e.g., Rizzo v. Goode, 423 U.S. 362 (1976); pp. 1329-30 infra.

${ }^{61}$ No attempt will be made here to give precise or discrete definitions of equity, comity, or federalism. While they may perhaps be isloated, see, e.g., The Supreme Court, 1975 Term, 89 HaRv. L. Rev. 47, I5 I n.2 (1975), Justice Black seems to have felt that the last two were inseparable, see Younger v. Harris, 401 U.S. 37,44 (1971). As a general proposition, this Part will steer clear of the Court's specific terminology and try to give content to its reasoning by examining the functional concerns that underlie the somewhat rhetorical equity, comity, and federalism trilogy.

${ }^{62}$ See p. $1279 \&$ note 40 supra. 
tion in Younger clearly responds to this concern. It expresses a preference, at the very least, for a declaratory form of relief where there is no reason to suppose that a declaration of invalidity - whether in the form of a declaratory judgment or a ruling in criminal court - will not provide a complete remedy for the plaintiff. This is made explicit by the fact that the Younger Court carved out an exception for cases involving prosecutorial harassment, thus reserving the possibility of injunctive relief where a mere declaration of invalidity might not prevent further prosecutions and harassment. ${ }^{63}$

(b) The Preference for Relief in a Criminal Forum. - Even in a unitary court system, a number of factors would support a preference for leaving would-be civil plaintiffs in the criminal forums in which they are already embroiled. First, requiring the plaintiff to litigate his constitutional claim in the course of his criminal prosecution is likely to conserve judicial and prosecutorial resources ${ }^{64}$ and protect prosecutorial discretion. Second, it will hasten punishment of unsuccessful claimants and therefore encourage compliance with the law. Third, it may be seen to serve an independent, a priori value in permitting the smooth and unimpeded operation of the collection of procedures that make up the normal course of criminal justice. Fourth, it might be argued that, insofar as opponents of the Younger cases belittle the fairness and competence of state courts, deference to state

${ }^{63}$ Samuels v. Mackell, 401 U.S. 66 (197I), holding that a constitutional decision in the course of a pending state criminal proceeding is preferable to a federal declaratory judgment, see p. I277 supra, may be seen in part to resnond to ? preference for noncoercive forms of relief because of the Court's conclusion that a federal declaratory judgment would have the same effect as an injunction, $40 \mathrm{r}$ U.S. at 73. Such reasoning, however, provides an incomplete perspective on Samuels because it assumes away, rather than analyzing, the questions why that effect will be the same and why it will be negative. The disinclination to award federal declaratory relief is better understood with regard to the other two forum allocation preferences discussed in text.

${ }^{64}$ The expenditure of judicial and prosecutorial resources will be increased by permitting adjudication in the civil forum whenever the state defendant loses in his declaratory judgment action and then raises the claim again during his state court defense. Where the defendant is successful on the merits, the total resource investment in the litigation will generally be the same as it would if he raised his claim at the outset of the criminal proceedings. It should be observed that this judicial economy argument is dependent on the not entirely plausible assumption that state and federal courts will reach the same constitutional decision. The contrary assumption that state courts are less sympathetic to constitutional claims than are federal courts could lead to different judicial economy predictions because whenever the state court incorrectly rules against the plaintiff, the process of securing a reversal within the state court system, on appeal to the Supreme Court, or through postconviction procedures will consume resources that might not have been consumed had a federal declaratory judgment action led to a correct initial determination. 
criminal courts is likely to be least objectionable because criminal procedures tend to be the most strictly regulated and scrutinized by the Supreme Court. ${ }^{65}$ In short, criminal forums may be preferred both from the perspective of the judicial system and out of concern for a broader view of the need to let law enforcement authorities function without undue interference.

(c) The Preference for Relief in a State Forum. - Three kinds of concerns favor state court adjudication. First, the decision to use the federal courts to decide issues that would otherwise be decided in the normal course of state proceedings often will be perceived as a direct affront to state courts. ${ }^{66}$ The more inefficient and unexpected such a decision is, the greater will be the affront. Major and frequent manifestations of disrespect for state courts and the resulting affront may be seen as undesirable because of their tendency to undermine confidence in state judges and therefore to make it more difficult for them to perform the myriad tasks thrust upon them in a federal system. Moreover, such manifestations might become self-fulfilling prophecies if state courts are widely scorned, important matters are habitually removed from their jurisdiction and incentives to exert political or social pressure to maintain or improve their quality are removed from prospective litigants. ${ }^{67}$

Second, a preference for state forums may rest upon a series of broad, a priori views about the history and value of states. Among them: that it is more appropriate for state courts to decide the validity of state laws; that such decisions are less intrusive than would be federal ones, either because the identical decision would be received with less hostility or because a different decision is likely; ${ }^{68}$ that state legislative, executive, and judicial

${ }^{65}$ Cf. Huffman v. Pursue, Ltd., 420 U.S. 592, 615-16 (1975) (Brennan, J., dissenting) (arguing that criminal process contains greater safeguards to prevent its frivolous invocation).

${ }^{66}$ See id. at 611 ; Steffel v. Thompson, 4I5 U.S. 452, 462 (1974).

${ }^{67}$ See generally Neuborne, The Myth of Parity, 90 HARv. L. Rev. Iro5 (1977). As in the case of many of the concerns that may be seen to support the Younger forum preferences, any argument based upon affront is partially dependent upon an assumption about the caliber of state courts. A concern with minimizing affronts to state courts must rationally focus primarily on unjustified affronts and secondarily on any self-fulfilling prophecy argument. To the extent that one adopts the assumption that substantial numbers of state courts are not equal to the task of adjudicating, or are openly hostile to, federally protected rights, the concern with affront diminishes substantially.

${ }^{68}$ Different outcomes might be seen as desirable either because state courts may be more sensitive to local peculiarities, see Neuborne, supra note 67 , at II 28 , or out of a view that state judges are less likely to impose countermajoritarian norms because of their closer ties to state politics, id. at Ir30-3I. 
machinery should have the opportunity to function unimpeded and arrive at equilibrium. ${ }^{69}$

Third, state forums may appear preferable to those eager to reduce the activities of the federal courts. This approach stresses either the beleaguered, docket-cluttered posture of the federal judiciary today ${ }^{70}$ or the relatively low priority - from some unarticulated national viewpoint - of some of the claims raised in Younger-type cases. In effect it may suggest that federal courts either are, or should be, recognized as a scarce resource and reserved for matters of greater dimension. ${ }^{71}$

The preceding three preferences define the parameters of what might be termed the forum-allocation component of Younger. They highlight the concerns with minimizing coercive remedies, conserving judicial and prosecutorial resources, encouraging compliance with the law, avoiding affronts between court systems, furthering state autonomy, and curbing federal judicial activism. Arrayed against them, of course, are the values underlying section $1983{ }^{72}$ doubts about the competence of state courts, ${ }^{73}$ and the extra protection that forum choice provides for constitutional claims. ${ }^{74}$ Our willingness to indulge forum allocation preferences in a given category of cases depends in part on the degree to which these countervailing factors are implicated. ${ }^{75}$

2. Constitutional Fallout. - Forum allocation preferences alone do not provide a complete framework for discussing the Younger cases. There is an elusive substantive component as well - one that goes beyond mere preferences for various forums and generalizations about the adequacy of state court systems. This component contains two strands.

First, the decision to discuss Younger in forum allocation

${ }^{69}$ See Harrison v. NAACP, 360 U.S. 167,178 (1959) (ordering abstention "so that federal judgment will be based on something that is a complete product of the State, the enactment as phrased by its legislature and as construed by its highest court."); p. I 263 supra.

${ }^{70}$ See, e.g., H. Friendly, Federal Jurisdiction: A General View 87-9I (1973).

${ }^{71}$ See id.

${ }^{72}$ See Mitchum v. Foster, 407 U.S. 225, 242-43 (1972); pp. II53-56 supra.

${ }^{73}$ See Neuborne, supra note 67, at $1121-24$; Mitchum v. Foster, 407 U.S. 225 , 242 (1972).

${ }^{74}$ Without casting any aspersions on the general competence of state courts, one might observe that the provision of forum choice will shift constitutional litigation to the most sympathetic - and hence the most protective-forum because rational forum-shopping plaintiffs may be expected to correct for local variations between state and federal judiciaries.

${ }^{75}$ This is particularly true because the forum allocation concerns discussed in text often support only relatively slight preferences. Further, they tend to be concerns that are cumulative in nature and therefore would not be undermined by occasional exceptions. 
terms is itself a decision of constitutional significance. It is a decision that the only constitutional issue at stake is the validity of the challenged state law - that being prosecuted under an arguably (or actually) invalid law is not itself a deprivation. ${ }^{76}$ Younger dismissals inevitably involve such secondary constitutional decisions about burdens of being prosecuted. These, in turn, appear to mandate a system of exceptions to the Younger rules that will be sensitive to the nature of the plaintiff's constitutional claim. ${ }^{77}$

Second, there is sometimes a tendency to use the categorical, rule-like quality of Younger to withhold federal relief in situations in which the only real issue is the merits of the plaintiff's underlying claim. If given free rein, this tendency would cloak within the forum allocation language of Younger a substantive command, or at least an advisory opinion, for the benefit of the state forum. Justice Black's consideration of overbreadth analysis in Younger foreshadowed this danger. ${ }^{78}$ His holding that the state court should decide the validity of the challenged statute was a clear forum allocation choice. Similarly, his conclusion that mere facial invalidity did not threaten the plaintiff with sufficient harms to abort the state proceedings went to the converse of the forum allocation choice - the harms of being prosecuted. But Justice Black fired a broader salvo as well. $\mathrm{He}$ argued that facial adjudication prevents a state "from carrying out the important and necessary task of enforcing . . . laws against socially harmful conduct that the State believes in good faith to be punishable." 79

The thrust of this attack is less than clear. As already pointed out, some deference to law enforcement activities may be thought desirable. $^{80}$ If so, it may support a preference for a criminal forum. And it may also supply an argument against facial declarations of invalidity. But the two arguments are not related. The rule laid down in Younger is based upon a comparison of different forms of relief in different forums and tells us little about the substantive legal standard that should ultimately be applied. Similarly, the propriety of the overbreadth doctrine is indepen-

${ }^{76} \mathrm{See}$ Younger v. Harris, 401 U.S. 37,46 (1971) ("No citizen or member of the community is immune from prosecution, in good faith, for his alleged criminal acts.") (quoting Watson v. Buck, 3I3 U.S. 387, 400 (I94I) (quoting Beal v. Missouri Pac. R.R., 312 U.S. 45, 49 (I94I))).

${ }^{77}$ It would surely be anomalous to permit a prudential forum allocation rule to shape the substance of constitutional rights without analysis of those rights. See pp. 1328-30 infra.

${ }^{78}$ See p. 1276 supra.

79 Younger v. Harris, 401 U.S. $37,51-52$ (1971).

${ }^{80}$ See p. 1283 supra. 
dent of the search for a proper forum. ${ }^{81}$ Younger is concerned primarily with where and when relief is proper and with the constitutional implications of decisions about where and when. To extend it further into the area of whether there is a violation is to impede analysis.

\section{The First Limits}

As the preceding Section illustrates, the 1971 decisions had a chameleon-like quality. They could mean different things to different observers. They considered a fact situation that was too easy, a plaintiff with too little to complain of, and a forum choice supported by too many intersecting concerns. It was not long, however, before the Court made some efforts to clarify and to narrow its early handiwork in response to concerns and values central to section 1983 .

In Mitchum v. Foster, ${ }^{82}$ the Court held that suits brought under section 1983 come within the "except as expressly authorized by Act of Congress" exception to the Anti-Injunction Act ${ }^{83}$ which bans federal courts from enjoining ongoing state proceedings. Justice Stewart's opinion for the Court vigorously invoked the nationalist and constitutional values embodied in the provision of a federal cause of action and a federal forum under section $1983 .{ }^{84} \mathrm{He}$ noted that one of the problems Congress recognized was the danger that state courts might be antipathetic to the vindication of federally created rights. ${ }^{85}$ And he pointed out that section I983 was "a product of a vast transformation from the concepts of federalism that had prevailed ... when the anti-injunction statute was enacted." ${ }^{86}$ While concluding that section 1983 was therefore an exception to that statute,

${ }^{81}$ From no perspective would it seem that the substantive standard should depend on which of the following scenarios precedes relief: (I) a federal district court applies the standard; (2) a state court applies the standard under the impression that failure to do so would invite reversal; (3) the Supreme Court applies the standard on review of a state court decision. The choice among scenarios may implicate federalism or comity concerns, just as the process of choosing a standard may. But the relationship stops there.

82407 U.S. 225 ( 1972 ).

${ }^{83}$ First enacted in 1793, Act of March 2, 1793, ch. 22, § 5, I Stat. 335, the Anti-Injunction Act is now codified at 28 U.S.C. $\$ 2283$ (1970). It states that a federal court "may not grant an injunction to stay proceedings in a State court except as expressly authorized by Act of Congress, or where necessary in aid of its jurisdiction, or to protect and effectuate its judgments." The statute's somewhat obscure history and original purposes are discussed in Toucey v. New York Life Ins. Co., 314 U.S. I18, 130-32 (I94I). See also Mitchum v. Foster, 407 U.S. 225 , 231-38 (1972); C. Wright, Law of Federal Courts I77-82 (2d ed. 1970).

${ }^{84} 407$ U.S. at $242-43$.

${ }^{85}$ Id. at 242 .

${ }^{86} I d$. 
Justice Stewart was careful to note that Mitchum did not "question or qualify in any way the principles of equity, comity, and federalism that must restrain a federal court when asked to enjoin a state court proceeding." ${ }^{87}$ Yet this reaffirmation of Younger could not obscure the emphasis on federal rights and the plights of federal plaintiffs. ${ }^{88}$

That emphasis was sharpened and reiterated in Steffel $v$. Thompson ${ }^{89}$ which confined the potentially very broad Younger principles to cases in which state proceedings are pending. Steffel held that a federal court may issue a declaratory judgment absent a showing of irreparable harm, bad faith, or other extraordinary circumstances when the plaintiff is not the target of a pending state prosecution. ${ }^{90}$ The Court emphasized that the Younger concerns with "equity, comity and federalism have little vitality" ${ }^{91}$ in the absence of a pending proceeding. Much of the opinion was devoted to establishing that the Declaratory Judgment Act ${ }^{92}$ was enacted to provide a remedy less intrusive than an injunction and one that should therefore be considered under

${ }^{87}$ Id. at 243 .

${ }^{88}$ The relationship between Mitchum and Younger is curious. It was by reference to the Anti-Injunction Act that Justice Black derived what he called a "longstanding public policy" against federal interference with state proceedings. Younger v. Harris, 401 U.S. 37,43 (I97I). Yet he went on to decide Younger while explicitly reserving the question whether the Anti-Injunction Act applied to suits brought under $\S 1983$. Id. at 54. Mitchum, however, took the statute which formed a portion of the foundation for Justice Black's edifice of restraint and concluded that it does not apply to suits that - like Younger - are brought under $\S 1983$. While not clearly inconsistent, the juxtaposition of the two cases does suggest a certain circularity. And one might well ask why, if $\S$ I 983 qualifies as an express exception from the letter of the statute, it does not also qualify as an exception to judge-made rules derived from the statute. The question is not addressed by the Court.

${ }^{89} 415$ U.S. $45^{2}$ (1974).

${ }^{90} I d$. at 475 . Justice Brennan's majority opinion cites and often tracks his separate opinion in one of the original Younger companion cases. See Perez v. Ledesma, 40I U.S. 82, 93-130 (1971) (concurring and dissenting opinion).

${ }^{91} 4 \mathrm{I} 5$ U.S. at 462 . In a somewhat different context, the Court had already held that these same principles "have little force in the absence of a pending state proceeding." See Lake Carriers' Ass'n v. MacMullan, 406 U.S. 498, 509 (1972) (considering the validity of state antipollution legislation). Analagously, the Court in Roe v. Wade, 410 U.S. II3 (1973), had reached the merits of an anticipatory challenge to criminal abortion statutes without suggesting that anything in Younger and Samuels stood in the way, id. at 166-67, although it did find that the Younger cases barred the suit of one plaintiff who was already enmeshed in state proceedings, id. at 125.

In addition to defining the limits of the Younger doctrine, Steffel, Lake Carriers, and Roe seem to have repudiated the sporadic tendency of earlier cases to invoke the language of restraint and comity where state proceedings were only threatened.

9228 U.S.C. $\$ 2201$ ( 1970$)$. 
a different standard. ${ }^{93}$ The Court recognized that the remedy was intended to spare plaintiffs from having to make the difficult choice between forgoing arguably protected conduct on one hand and violating criminal statutes and risking penalties on the other, ${ }^{94}$ and held without hesitation that, if appropriate at all, such relief was appropriate in federal court. ${ }^{95}$ The possibility that the case should be dismissed and the remedy sought in state court was referred to only obliquely and swiftly rejected ${ }^{96}$ In forum allocation terms, the Court declined seriously to consider requiring the plaintiff to seek a noncoercive civil remedy in state court rather than an equally noncoercive civil remedy in federal court when the state system was not already involved in the case. It focused only on whether declaratory relief was appropriate. Where was considered an easy question - almost a given.

Its very easiness sheds a good deal of light on the foundations of the Younger decisions. If the presence of pending state proceedings is critical to a Younger dismissal - as Steffel holds then the Younger rule clearly does not rest on concerns that are of equal force whether state proceedings are pending or not. Accordingly, neither the need to reduce the role of the federal courts nor a general view of the appropriateness of permitting state courts to test the constitutionality of state laws can be sufficient grounds for a Younger dismissal. ${ }^{97}$ Rather, to the extent that Younger expresses a preference for state forums, it responds primarily to the component of that preference which seeks to avoid affronts by permitting state courts to decide questions that would ordinarily come up in the normal course of ongoing proceedings. ${ }^{98}$

${ }^{93} 4 \mathrm{I} 5$ U.S. at $466-73$. See also Zwickler v. Koota, 389 U.S. 24I, 254 (1967) (recognizing different standards and the need for separate inquiries into appropriateness of injunctive and declaratory relief). An injunction and its accompanying threat of contempt citations are likely to be a more intrusive remedy than a declaratory judgment both because of their symbolic force and because of the danger that they will genuinely chill prosecutors from bringing charges at the periphery of the underlying constitutional decision when those prosecutions might be permissible.

${ }^{94} 415$ U.S. at 462 .

${ }^{95} \mathrm{Id}$. at 475 .

${ }^{96} I d$. at $472-73$. The Court observed that exhaustion of state judicial remedies had not been required in suits brought under $\S \mathrm{I} 98_{3}$, cited Monroe v. Pape, 365 U.S. 167 (1961), and noted that denying relief in Steffel would have amounted to the imposition of a form of exhaustion requirement. See 4I5 U.S. at 473 . See generally Part V, pp. I264-74 supra.

${ }^{97}$ Both factors, of course, are present in Younger and Steffel. They do not vary with the pendency of state proceedings and are therefore not determinative.

${ }^{98}$ It seems quite clear that a concern with avoiding affront to state courts will vary with the presence or absence of state proceedings. The notion of affront contains a built-in normative component - it depends on the removal from a 
Further, the Steffel result suggests that the concerns underlying the preference for criminal over civil forums was of substantial importance in Younger. For, in contrast to the I97I cases, those concerns are almost wholly absent in the Steffel situation. There is no interest in exacting swift penalties when the plaintiff is not being prosecuted. ${ }^{99}$ The forum choice will have no impact on prosecutorial or judicial resources. ${ }^{100}$ And the availability of anticipatory relief in the forum of the plaintiff's choice will give him a greater incentive briefly to forgo arguably prohibited conduct and challenge the statute rather than violating it - thus furthering the state's interest in exacting compliance with its laws. ${ }^{101}$

The plaintiffs in Steffel did not seek an injunction on appeal, and the holding was therefore limited to the propriety of declaratory relief. ${ }^{102}$ For many of the reasons already discussed, however, the absence of a pending state proceeding would seem logically to require that an injunction be available without a Younger showing of extraordinary irreparable harms. An injunction issued in the absence of state proceedings - like a declaratory judgment in the same situation - would not reflect poorly on the competence of state courts, interfere with the normal course of criminal proceedings, or prevent the state from exacting

state court of an issue that would normally be tried in that court under circumstances that suggest the removal is motivated by a lack of confidence. A broad rule conferring federal question jurisdiction or civil rights jurisdiction on the federal judiciary does not suggest such a departure from the expected course of things - or at least does not do so today, more than Ioo years after such jurisdiction was created. However, when a state judge is about to decide an issue and the federal court steps in, the picture is somewhat different and there might reasonably arise a concern with the respect due to state courts. As Justice Brennan observed in Steffel, "nor can federal intervention, in that circumstance [i.e., where no state proceedings are pending], be interpreted as reflecting negatively upon the state court's ability to enforce constitutional principles." 415 U.S. at 462 .

${ }^{99}$ The plaintiff in a preenforcement declaratory judgment action often will not have violated the challenged statute and thus cannot implicate any state interest in exacting penalties.

${ }^{100} \mathrm{See} 4 \mathrm{I} 5$ U.S. at 462 .

${ }^{101}$ The Steffel result actually supports three interrelated compliance incentives. First, it ensures the availability of preenforcement relief in a proper case and thus enables plaintiffs to test their rights without stepping outside the law and risking criminal penalties. Second, it gives them an incentive to do so in addition to the desire to avoid penalties by providing what amounts to a free bite at the apple, for if the plaintiff loses he can try again as a state court criminal defendant if he chooses to violate the law. Third, to the extent that some plaintiffs desire to secure a federal forum because of their perceptions about the relative desirability of different court systems, the juxtaposition of Steffel and Younger encourages them further to avoid violating the law by keying the availability of federal relief to compliance.

${ }^{102} 415$ U.S. at 456. 
a criminal penalty. In short, the drawbacks of both remedies are diminished where no state charges are pending. ${ }^{103}$

Yet the preference for noncoercive forms of relief noted in the preceding Section and the historic equity rules which reflect it clearly require a greater showing for an injunction than for a mere declaratory judgment. ${ }^{104}$ As observed above, the Declaratory Judgment Act was intended in part to permit anticipatory relief in circumstances where a showing of irreparable harm could not be made and where the coercive nature of injunctive relief was not necessary. ${ }^{105}$ To obtain an injunction, a plaintiff in the Steffel situation should therefore have to demonstrate that he needs something more than a declaration that the law he challenges is invalid. ${ }^{106}$ This requirement could be met where the prosecutor's prior behavior supports an inference that he will ignore a valid declaratory judgment and subject the federal plaintiff to further burdens. But the process of scrutinizing an official's record and drawing inferences about the likelihood of his behaving in bad faith may implicate federalism concerns. While no reasonable policy of deference to state officials would stand in the way of an injunction where the inference of bad faith was clearly accurate, there might well be considerable uncertainty about the prosecutor's likely future conduct. In such a case, policies urging respect for state officials might be seen to support a relatively strict standard to ensure that the federal courts err on

${ }^{103}$ The decision this Term in Wooley v. Maynard, 45 U.S.L.W. 4379 (U.S. April 20, 1977) suggests that the Court will not apply the stringent Younger standards to preenforcement requests for injunctions against future prosecutions. Plaintiffs there won an injunction on the basis of a showing which, notwithstanding language in the opinion to the contrary, $i d$. at $438 \mathrm{I}$, cannot be seen as sufficient to meet the extra-heavy Younger requirements. The plaintiffs challenged a New Hampshire statute making it a misdemeanor knowingly to cover the state motto on automobile license plates. Id at 4380 . The Court found the statute unconstitutional and enjoined its enforcement, justifying the decree on the basis of three successful prior prosecutions against one of the plaintiffs. Id. at 438I. Yet those prosecutions had predated any determination that the state law was unconstitutional. Id. at 4380 . Accordingly, the fact of those prosecutions did not suggest that future prosecutions were likely to occur in the wake of an authoritative constitutional pronouncement. Despite its citations to Younger cases, id. at $4380-8 \mathbf{I}$, it is therefore difficult to conclude that the Court was applying anything stricter than a minimal irreparable harm standard. Indeed, even under such a standard the result may be difficult to justify. See note 106 infra. Other aspects of the Maynard case are discussed at pp. 1344-45 infra.

${ }^{104}$ See Doran v. Salem Inn, Inc., 422 U.S. 922, 930-31 (I975).

${ }^{105}$ See pp. I 288-89 supra; Steffel v. Thompson, 415 U.S. 452, 47 I-72 (1973).

${ }^{106}$ This reasoning strongly suggests that the injunction in Wooley v. Maynard, 45 U.S.L.W. 4379 (U.S. April 20, 1977), see note ro3 supra, was inappropriate. Not only must the Court have been applying a nonrestrictive standard to issue it, but it appears in fact to have applied no standard - in effect to have collapsed inquiries into the propriety of declaratory and injunctive relief into a single quest. 
the side of deference and caution. ${ }^{107}$ Where such a standard is imposed, the plaintiff's federal rights should be protected after the fact by recognizing that a prosecutor's decision to file charges under a statute that has been declared invalid would generally mandate an exception to the Younger rule requiring dismissal. ${ }^{108}$ Such an exception would not lead to unjustified insults to state prosecutors because it would only come into play after the uncertain inference-drawing process has been supplanted by a record of actual conduct. Thus there would be no danger of unjustified inferences of bad faith.

\section{Justiciability}

Steffel and Younger provide alternative routes for citizens to challenge the constitutionality of state laws. Under the former, a person can obtain a preenforcement declaratory judgment. ${ }^{109}$ Under the latter, he can violate the statute at issue and raise his constitutional claims in the course of state court proceedings. ${ }^{110}$ In a sense, the two routes stand in a reciprocal relationship: to the extent that preenforcement relief is not available, Younger-type cases will be more common.

Maintaining access to preenforcement declaratory judgments will generally be in the interests of prospective plaintiffs and society alike for a number of reasons. ${ }^{111}$ First, such relief tends to reduce uncertainty and with it the likelihood that persons will refrain from engaging in conduct that is actually protected by the Constitution and hence often valuable. Second, a system which bars anticipatory relief in effect requires that some persons violate the law to realize the socially desirable goals of reducing the uncertainty and the chilling effects of vague and overbroad statutes. Building in a need for violations is unlikely to spread re-

107 The imposition of such a strict standard would not be proper under the Younger rubric because, as already observed, the particular concerns that appear central to Younger are not directly relevant in the absence of pending state proceedings. This is not, of course, to deny some indirect analogies between Younger standards and broader policies that may counsel deference. The point is the more limited one that it can only lead to confusion if all decisions implicating federalism-related values are bundled into a single doctrinal package with the appellation Younger.

108 The text assumes, of course, that the prosecutor is seeking to apply the law in a way contrary to the substance of a valid declaratory judgment. For a more general discussion of the effect of federal declaratory judgments, see pp. 1354-60 infra.

${ }^{109}$ See pp. I 288-89 supra.

110 See pp. 1275-78 supra.

${ }^{11}$ See generally E. Borchard, Declaratory Judgments (2d ed. I94I) ; Perez v. Ledesma, 40I U.S. 82, III-I5 (I97I) (Brennan, J., concurring and dissenting) (discussing legislative history of the Federal Declaratory Judgment Act). 
spect for the law or forward the more general social interest in exacting compliance with valid laws. Third, such a system will be forced sometimes to condemn and punish persons for behavior in which they would not have engaged but for the good faith belief that it could not be prohibited. Fourth, as already discussed, preenforcement review permits the plaintiff to choose his own forum. To the extent that plaintiffs will behave rationally and choose the most favorable forum, this may provide desirable extra protection for constitutional rights even in a system in which state courts are presumptively equivalent to federal ones. Where there exist doubts about state forums, such extra protection is even more desirable.

The availability of preenforcement review in federal courts is largely regulated by the "actual controversy" requirement in the Declaratory Judgment Act, ${ }^{112}$ the "case or controversy" requirement of article III, ${ }^{113}$ and the various prudential rules that purport to build on those requirements. A restrictive application of these threshold standards may in effect permit Younger to swallow up Steffel ${ }^{114}$ and sharply curtail the availability of federal preenforcement review.

Inquiries into the justiciability of a dispute or the existence of an article III case or controversy may be made under a number of overlapping rubrics including standing ${ }^{115}$ injury in fact, ${ }^{116}$ ripeness and mootness, ${ }^{117}$ the actual controversy requirement, ${ }^{118}$

11228 U.S.C. \$ $220 \mathrm{r}$ (1970).

113 U.S. Const. art. III.

${ }^{114}$ Cf. Doe v. Randall, 314 F. Supp. 32, 35-37 (D. Minn. 1970) (three-judge court) (alternative holding), aff'd mem. sub nom. Hodgson v. Randall, 402 U.S. 967 ( $197 \mathrm{r}$ ). In that case a doctor's challenge to an antiabortion statute was dismissed as nonjusticiable because no indictment had been returned. On petition for a rehearing, the court refused to intervene because state proceedings had commenced.

${ }^{115}$ See generally L. Jaffe, Judicial Control of Administrative Action 459-539 (1965); Albert, Standing to Challenge Administrative Action: An Inadequate Surrogate for Claims for Relief, 83 YALE L.J. 425 (1974); Berger, Standing to Sue in Public Actions: Is It a Constitutional Requirement?, 78 Yale L.J. 8 I6 (I969); The Supreme Court, 1975 Term, 90 HaRv. L. Rev. 56, 205-I3 (1976) (discussing Simon v. Eastern Ky. Welfare Rights Organization, 426 U.S. $26(1976))$.

${ }^{116}$ See, e.g., Association of Data Processing Serv. Organizations, Inc. v. Camp, 397 U.S. 150, 152 (1970).

${ }^{117}$ See generally Note, The Mootness Doctrine in the Supreme Court, 88 Harv. L. REv. 373 (I974); cf. Steffel v. Thompson, 4I5 U.S. 452, 476 (I974) (Stewart, J., joined by Burger, C.J., concurring) (suggesting plaintiffs will have difficulty showing that their claims are not too speculative or premature). See also Spomer v. Littleton, 4I4 U.S. 514 (I974). 
separation of powers, and the political question doctrines. ${ }^{119}$ Analysis of the justiciability problem tends to be clouded by the conclusory language of the cases, ${ }^{120}$ the blend within the doctrines of constitutional and discretionary components, ${ }^{121}$ and the recurring difficulty of separating what purports to be a threshold question from the merits of the case. ${ }^{122}$

Beneath the morass, there do exist a number of concerns and policies which justiciability doctrines are intended to further. Among them: (I) ensuring that the adversary process will effectively sharpen the issues presented, provide adequate representation for opposing views, and compensate for the fact that the court may not be well equipped to gather and evaluate all the relevant

118 "Actual controversy," is the language of the Declaratory Judgment Act, 28 U.S.C. \$ $220 \mathrm{I}$ (I970). While it could not, of course, cut back on the core constitutional requirement, the legislative intent to ease access to the federal courts for anticipatory relief, see p. I288 supra, would seem to cut against judge-made rules imposing greater than minimum threshold requirements.

${ }^{119}$ See generally United States v. Nixon, 4I8 U.S. 683 (1974); Powell v. McCormack, 395 U.S. 486, 518-49 (I969); Baker v. Carr, 369 U.S. I86, 208-18 (r962). As a general proposition, the clearest strand of the political question doctrine - the notion that certain questions are expressly consigned to another branch - is of little relevance here.

${ }^{120}$ See, e.g., Association of Data Processing Serv. Organizations, Inc. v. Camp, 397 U.S. I50, I5I (I970) ("Generalizations about standing to sue are largely worthless ...."); Joint Anti-Fascist Refugee Comm. v. McGrath, 34I U.S. I23, I5O (I95 I) (Frankfurter, J., concurring) ("The jurisdiction of the federal courts can be invoked only under circumstances which to the expert feel of lawyers constitute a 'case or controversy.' ")

${ }^{121}$ Though hard to identify, the constitutional component is clearly established in text, see U.S. CoNST. art. III, embodied in the general notion of separation of powers, and reflected in the rule against advisory opinions, see HART AND Wechsler, supra note 45, at 64-70; Note, Advisory Opinions on the Constitutionality of Statutes, 69 HARv. L. REv. I302 (1956). But a substantial discretionary component also is reiterated throughout the case law and literature. See, e.g., Flast v. Cohen, 392 U.S. 83 (I968); Poe v. Ullman, 367 U.S. 497, 502-03 (I96I) (Frankfurter, J.) (noting that article III "is not the sole limitation on the exercise of our appellate powers, especially in cases raising constitutional questions"); Joint Anti-Fascist Refugee Comm. v. McGrath, 34I U.S. I23, I56 (I95I) (Frankfurter, J., concurring) (noting fact that "hardship of denying judicial relief" is part of inquiry into justiciability); Ashwander v. Tennessee Valley Auth., 297 U.S. 288, 346-48 (I936) (Brandeis, J., concurring) (discussion of judge-made techniques for avoiding constitutional questions). See generally Stewart, The Reformation of American Administrative Law, 88 HARv. L. REv. I667, I740-44 (I975) (arguing that restrictive discretionary standing requirements may be more appropriate in constitutional cases than in statutory ones because judicial resolution of the former may remove a case entirely from the political process).

${ }^{122}$ See, e.g., Rizzo v. Goode, 423 U.S. 362 ( 1976 ) (dismissal on case or controversy grounds shades into discussion of merits); Warth v. Seldin, 422 U.S. 490, 520 (1975) (Brennan, J., dissenting) (remarking that standing decision expresses hostility to merits); O'Shea v. Littleton, 4I4 U.S. 488, 490-99 (I974). 
data; ${ }^{123}$ (2) avoiding unnecessary adjudication, both to conserve judicial resources and to prevent the court from setting unnecessary constitutional precedents; ${ }^{124}$ and (3) preventing the court from intruding into the jurisdiction of other branches and putting some checks on the exercise of its essentially undemocratic powers. ${ }^{125}$

Ordinarily, a court can make three overlapping inquiries to further these goals. First, it can scrutinize the parties before it and require some assurance that they will function effectively in an adversary setting - perhaps by insisting on plaintiffs with a personal stake in the outcome ${ }^{126}$ and defendants who may properly be required to provide some relief. ${ }^{127}$ While often subsumed under the broad rubric of standing, this issue is perhaps better referred to as the requirement that there be proper parties. Second, the court can look to the timing of the litigationwhether the claims are not yet ripe for decision or whether they have become moot in light of intervening events. This is the proper timing requirement. ${ }^{128}$ Finally, the court may conclude that a claim does not present a proper case - perhaps because the issues are explicitly consigned to another branch, perhaps because they are outside the competence of courts, perhaps because they are and always will remain too speculative, or perhaps because they implicate some elusive, further-flung strand of the political question doctrine. ${ }^{129}$

As a general proposition, the proper case problem should be of

${ }^{123}$ See, e.g., Flast v. Cohen, 392 U.S. 83, 99-101 (1968) ; Sierra Club v. Morton, 405 U.S. 727, 731-32 (1972).

${ }^{124}$ See Ashwander v. Tennessee Valley Auth., 297 U.S. 288, 346-48 (1936)

(Brandeis, J., concurring).

${ }^{125}$ See generally cases cited note I 9 supra.

${ }^{126}$ See, e.g., Warth v. Seldin, 422 U.S. 490, 498-99 (I975) ; Flast v. Cohen, 392 U.S. 83 , 99-IOI (I 968 ).

${ }^{127}$ See, e.g., Simon v. Eastern Ky. Welfare Rights Organization, 426 U.S. 26, 40-42 (1976) ; Linda R.S. v. Richard D., 410 U.S. 614, 618-I9 (I973).

${ }^{128}$ The timing and party requirements may be intimately related. In particular, a party can be improper because, as to him, the case either is not yet ripe or has been rendered moot. But parties may be held improper for reasons having nothing to do with timing. See, e.g., Warth v. Seldin, 422 U.S. 490, 498-502 (I975). And a claim may be regarded as not ripe with regard to all rather than just some possible parties. See, e.g., Poe v. Ulman, 367 U.S. 497, 507-09 (I96I).

${ }^{129}$ It is not contended that the proper case requirement can be neatly isolated from the other two. However, it is useful to attempt to distinguish those dismissals which suggest that the claim can eventually be brought - either by a better situated party or at a later time - from those in which, however classified, the threshold decision effectively means that the claim can never be raised in federal court. See, e.g., United States v. Richardson, 4I8 U.S. 166, I79 (1974). The proper case requirement is meant to include these latter kinds of dismissals and thus often seems similar to a decision on the merits. 
scant relevance to preenforcement attacks on the validity of criminal statutes. There is little doubt that the constitutionality of state laws is a proper issue for the courts, and it is clear that preenforcement review does not itself force the court onto inappropriate terrain. ${ }^{130}$ The policies underlying the justiciability doctrines are therefore primarily implicated in the anticipatory relief situation by the party and timing requirements. ${ }^{131}$

Steffel itself presented a fairly easy case. The plaintiff was able to show a specific threat of enforcement and to point to a companion who had violated the challenged criminal trespass law and been prosecuted. ${ }^{132}$ Those showings left little doubt that state officials intended to enforce the law against Steffel if he engaged in the specific conduct which he claimed could not constitutionally be prohibited. But Justice Stewart, concurring, suggested that such a showing was "exceedingly rare." ${ }^{133}$ And Justice Brennan's opinion for the majority noted that Steffel still had not conclusively met a final burden - the requirement that there be a continuing controversy. ${ }^{134}$ One of the issues left to the lower court on remand was whether the diminution of concern over the Vietnam War in the years since the complaint was filed had mooted Steffel's claim by defusing the issue about which he sought to distribute handbills. ${ }^{135}$ Both suggestions contain seeds of an un-

${ }^{130}$ At the time of the passage of the Declaratory Judgment Act in 1934,48 Stat. 955 , there was some question whether declaratory judgments would in effect amount to unconstitutional advisory opinions. See, e.g., Willing v. Chicago Auditorium Ass'n, 277 U.S. 274 (I928). The Court upheld the Declaratory Judgment Act in Aetna Life Ins. Co. v. Haworth, 300 U.S. 227 (r937). That case, however, was an action by the insurance company for a declaration that policies held by the defendant had been voided by his failure to pay premiums. The defendant alleged that a disability had relieved him of the obligation to pay. The case thus considered the consequences likely to flow from prior and continuing events. It did not pose the question of purely future conduct raised, and now settled, in anticipatory challenges to criminal statutes like those discussed in this Part.

${ }^{131}$ Before discussing these requirements in the context of preenforcement suits for declaratory relief, it should be reemphasized that those suits do not - after Steffel-pose Younger problems. In Boyle v. Landry, 40r U.S. 77 (I97I), the Supreme Court had used the Younger requirement of super-irreparable harm to deny injunctive relief to plaintiffs who were not being prosecuted under the specific state law at issue. See pp. r277-78 supra. In Steffel's wake it is clear that, whatever the wisdom of that outcome, Younger provided an inappropriate route. Its particular concerns were of little vitality in that situation. There were three real issues: Was the case justiciable? If so, was the challenged statute invalid? And, if so, was an injunction proper or would a less intrusive remedy have sufficed? This Section is concerned with the first question only and thus need not employ the language of irreparable harm which would be relevant to the third.

132 Steffel v. Thompson, 4I5 U.S. 452, 455-56 (I974).

${ }^{133} I d$. at 476 .

${ }^{134}$ Id. at $459-60$.

135 Id. at 460 . 
necessarily restrictive approach to justiciability which, if nurtured, could undermine the concerns favoring anticipatory relief.

Although some Supreme Court decisions seem to have required a specific threat of enforcement ${ }^{136}$ - sometimes under the theory that the requirement was constitutionally compelled by the eleventh amendment and the fiction of Ex parte Young ${ }^{137}$ recent cases have taken a broader view and recognized that the probability of enforcement and a general picture of the categories of conduct likely to be prosecuted under the challenged statute can frequently be inferred from circumstances. ${ }^{138}$ Where newly enacted legislation applies by its terms to a discrete and readily identified class of persons or conduct, for example, one often may presume that it will be enforced against that class. ${ }^{139}$ Similarly, history and contemporary practice under older statutes may support clear inferences as to likelihood and probable use. ${ }^{140}$

Unlike a specific threat of enforcement made to the plaintiff,

${ }^{136}$ See, e.g., Poe v. Ullman, 367 U.S. 497 (I96I) ; Ex parte La Prade, 289 U.S. 444 (1933).

${ }^{137} 209$ U.S. 123 (I 908 ). The theory stems from the Young Court's use of an individual tortfeasor rationale to escape eleventh amendment objections to federal relief. See p. IIg6 supra. By casting the complaint as one against an individual official, the Young fiction suggested that a case or controversy had to be shown with that official. Hence a threat that he would enforce the challenged law could be required rather than a more generalized showing that the law was being enforced. See generally Comment, Threat of Enforcement-Prerequisite of a Justiciable Controversy, 62 CoLUM. L. Rev. I06, III-I3 (1962); see also Spomer v. Littleton, 4I4 U.S. 514 (1974) (remanding for determination whether election of new State's Attorney moots controversy).

${ }^{138}$ See, e.g., Doran v. Salem Inn, Inc., 422 U.S. 922 (I975); Doe v. Bolton, 4 Io U.S. I79, I88 (r973) (permitting physician to challenge antiabortion law because of likelihood he will be asked to perform an abortion and will then have to choose between forgoing conduct or facing prosecution); Epperson v. Arkansas, 393 U.S. 97 ( 1968 ) (implicitly finding justiciability in teacher's attack on antievolution statute). Somewhat more restrictive is Rincon Band of Mission Indians v. County of San Diego, 495 F.2d I (gth Cir.) (generalized threat to enforce too speculative to create actual controversy), cert. denied, 4 I9 U.S. 1008 (I974).

${ }^{139}$ See Lake Carriers' Ass'n v. MacMullan, 406 U.S. 498 (1972); Pierce v. Society of Sisters, 268 U.S. 5 ro (I925) (permitting injunction despite absence of any threat of immediate enforcement because statute was in effect self-executing) ; Joseph v. Blair, 482 F.2d 575 (4th Cir. 1973), cert. denied, $4 \mathrm{I} 6$ U.S. 955 (1974); cf. Pennsylvania v. West Virginia, 262 U.S. 553 (1923) (sufficient threat of injury found in statute that might lead to withdrawal of natural gas from interstate market before provisions permitting such withdrawal had gone into effect).

It is not suggested that the Supreme Court has steadily adhered to this analysis. See United Pub. Workers v. Mitchell, 330 U.S. 75 (1947) (finding nonjusticiable an attack on statute by the class of persons to whom it applied.)

${ }^{140}$ See, e.g., Doe v. Bolton, 410 U.S. I79, I88-89 (1973); Anderson v. Nemetz, 474 F.2d 814 (9th Cir. 1973). 
an inference, however justified, that the state plans to enforce challenged legislation may leave open a further question - the particular plaintiff's relationship to the case. Where the plaintiff presents evidence leading to the inference that he will be prosecuted, he will have established the requisite personal stake in the controversy. ${ }^{1+1}$ But laws may be challenged by persons who could not themselves be prosecuted and nonetheless have a powerful and direct interest in the case. It has been held, for example, that pregnant women may challenge statutes prohibiting doctors from performing abortions. ${ }^{142}$ The Court has not, however, recognized couples in which the woman is not pregnant as proper parties in such suits. ${ }^{143}$ Efforts to make such distinctions apparently depend on the assumption that, by virtue of their relationship to a challenged statute, some plaintiffs are less able to perform their adversary role than others even though all say they are committed to the litigation. Such distinctions depend as well on the court's confidence in its ability to recognize improper parties on the basis of objective criteria. Whether either premise is justified has been sharply questioned. ${ }^{144}$

Similar problems may be presented by the requirement of a continuing controversy if it is given too expansive an interpretation. There is no doubt that some claims may genuinely be mooted. ${ }^{145}$ But to dismiss a complaint like that in Steffel on grounds that the leaflet distributor's cause has become history appears both harsh and inefficient. There is no reason to believe that the plaintiff lacks another cause, nor to assume that his adversary vigor has been sapped.

There may, of course, be anticipatory challenges difficult to support on the basis of inferences about enforcement probabilities - perhaps because the statute under attack is too vague, or too new, or too old. Occasionally, such statutes may be of constitutional concern, either because of the opportunity they provide for prosecutorial bad faith or because of the uncertainty and chill caused by their broad sweep even if rarely enforced. To guard against the first problem, it may sometimes be appropriate to require the prosecutor to cooperate in resolving ambiguities about his future plans with regard to a particular statute and particular conduct. The danger is that law enforcement officials may secure a dismissal of suits for anticipatory relief on grounds that the

${ }^{141}$ In effect, he will have made a showing functionally equivalent to that of a threat of enforcement.

142 Roe v. Wade, 4 Io U.S. II3, I24 (I973).

${ }^{143} I d$. at $127-29$.

${ }^{144}$ See generally Scott, Standing in the Supreme Court - A Functional Analysis, 86 Harv. L. REv. 645 ( I973).

${ }^{145}$ See, e.g., Allee v. Medrano, 4I6 U.S. 802, 818 (1974) (statutes repealed). 
absence of a threat of enforcement leaves the plaintiff with no justiciable claim and may then file charges against the erstwhile plaintiff. This could be prevented, and justifiable reliance protected, by either of two closely related techniques. The prosecutor might be held estopped from enforcing the statute against the plaintiff, at least until intervening events put the plaintiff on notice. Alternatively, the plaintiff could be allowed to assert his reliance on the prosecutor's prior behavior as a defense to criminal charges. While neither approach at first glance comports entirely with established notions of prosecutorial discretion, ${ }^{146}$ some control would appear to be justified in a situation that poses such an obvious risk of bad faith.

The chilling uncertainty of very broad statutes is more problematic. In a partial response, the Court has relaxed standing under the overbreadth doctrine to allow persons being prosecuted to attack the facial sweep of statutes without proving that their own conduct could not constitutionally be prohibited. ${ }^{147}$ Where there exists a threat or inference of enforcement sufficient to support an anticipatory challenge, overbreadth analysis would similarly seem to permit a plaintiff in effect to assert the rights of others. It is conceivable that there might exist a vague or overbroad statute so successful in chilling arguably protected behavior that no one, or virtually no one, violates it. Such a statute would defy enforcement probability inferences and escape attacks by actual defendants so long as no charges were filed. The example, however, is somewhat implausible. It rests on the dubious premise that legislation which is never enforced will be familiar to large numbers of persons and will cause them to forgo arguably protected behavior. Should something approaching this hypothetical actually arise, present doctrines seem flexible enough to permit exceptions. ${ }^{148}$

Maintaining some flexibility is important more broadly because of the danger that timing and party requirements can combine in some contexts to make it impossible ever to assert certain claims - a result approaching that of a decision on proper case grounds or even a negative decision on the merits. Such a result

${ }^{146}$ Cf. Inmates of Attica Correctional Facility v. Rockefeller, 477 F.2d 375 (2d Cir. I973) (subjecting prosecutorial decisions to federal court supervision deemed inadvisable).

${ }^{147}$ See generally Note, The First Amendment Overbreadth Doctrine, 83 Harv. L. Rev. 844 (1970). The overbreadth doctrine was narrowed in Broadrick v. Oklahoma, 4I3 U.S. 60I, 6I2-I5 (r973), which limited it explicitly to state efforts to sanction "pure speech" and required "substantial" overbreadth to trigger the doctrine, $i d$. at 615 .

${ }^{148}$ Cf. Epperson v. Arkansas, 393 U.S. 97 (1968) (challenge to unenforced antievolution statute). 
may, of course, be correct in certain cases. But it should be reached by a consideration of either the proper case rules or the merits, not by a mechanical application of prudential doctrines relating to timing and parties.

O'Shea v. Littleton ${ }^{149}$ illustrates the dangers. Plaintiffs, civil rights activists, charged a magistrate and a judge with discriminating against them in bond setting, jury fees, and sentencing. ${ }^{150}$ The Court held the claims too speculative and dismissed on article III grounds. ${ }^{151}$ In addition, the Court felt that plaintiffs who might be able to assert less speculative claims would be barred from federal court under Younger. ${ }^{152}$ However, as the dissent observed, the state procedures to which the majority was apparently willing to relegate such plaintiffs probably would not have provided an opportunity for litigating class-based claims of discriminatory sentencing. ${ }^{153}$

O'Shea thus presents a case in which the alleged discriminatory practices would, if proven, be a fairly clear constitutional violation. ${ }^{154}$ It deals with an area - criminal justice - in which the judiciary has broad competence and authority. It was brought by the only group of plaintiffs available within the constraints imposed by other prudential rules which the Court does not seem willing to modify. There was no reason to doubt the vigor with which those plaintiffs would press their claim. Nonetheless, the Court held - explicitly on constitutional grounds ${ }^{155}$ - that there was no case or controversy. The result appears to call either for a more careful application of justiciability rules or for a more sensitive application of Younger. ${ }^{156}$

${ }^{149}{ }_{4} \mathrm{I} 4$ U.S. 488 (1974). For decisions echoing the problems in O'Shea, see Calvin v. Conlisk, 534 F.2d I25I (7th Cir. 1976); Bonner v. Circuit Court, 526 F.2d I33 I (8th Cir. I975) (en banc), cert. denied, 424 U.S. 946 (1976); Gardner v. Luckey, 500 F.2d 712 (5th Cir. 1974), cert. denied, 423 U.S. 84I (1975).

${ }^{150} 4 \mathrm{I} 4$ U.S. at $49 \mathrm{I}-92$.

${ }^{151} I d$. at $493-99$. The Court also said, in what seems to have been an alternative holding, that the kind of federal interference with a state criminal justice system which the plaintiffs sought would have been barred by Younger. Id. at 499-500.

${ }^{152}$ Id. at 496 . The problem is that to have a less speculative claim, a plaintiff would have to be enmeshed in the state system. The Court seemed willing to apply Younger to plaintiffs in that situation. Id.

${ }_{153}^{15} \mathrm{Id}$. at 5 IO-II.

${ }^{154}$ Cf. Yick Wo v. Hopkins, 118 U.S. 356 (1886) (discriminatory application of municipal ordinance violates the Constitution).

${ }^{155} 4 \mathrm{I} 4$ U.S. at 493.

${ }^{156} \mathrm{It}$ is the intersection of justiciability and Younger that gives O'Shea its preclusive power. Slack at either end would permit some group of plaintiffs to assert the claim. 


\section{E. Coverage Rules}

Steffel made it clear that Younger would not, and should not, become a broad call for federal judicial avoidance whenever the plaintiff might seek similar relief by filing in state court. It declined, in other words, to reverse the no-exhaustion holding of Monroe v. Pape ${ }^{157}$ and establish state courts as the primary forum for constitutional claims. Rather it established Younger as a rule against federal interference in one category of cases - those in which the plaintiff is the target of a state criminal prosecution. But the broad language in Younger had strongly suggested - and nothing in Steffel clearly refuted - the possibility that the rule requiring dismissal and its underlying policies might have some ramifications beyond the paradigm Younger fact situation.

The task of giving content to those ramifications has fallen to subsequent cases which addressed the ambiguities left by the juxtaposition of Younger and Steffel. It continues to be a task with two components. First, the factors which trigger a Younger dismissal need to be identified and crystallized into a series of criteria that define the coverage of the rule against federal interference. These criteria must also distinguish those situations in which, if relevant at all, Younger provides only an analogy and not a mandate to dismiss. Steffel highlighted one such coverage requirement: there must be a pending state proceeding. But it left unanswered a number of important coverage questions. Among them: At what point in time is the pendency of state proceedings measured? What kinds of state proceedings require federal dismissal? Who is precluded from seeking relief in federal court? What kind of federal relief is barred?

These issues sometimes shade into the second component of the Younger analysis - the need to define those ad hoc considerations which are sufficient to overcome the rule against certain kinds of interference even when the factors which normally trigger that rule are present. This is the task of defining exceptions to Younger which will protect constitutional values and the plaintiffs who assert them. Its goal is to ensure that the Younger rules minimize not just the costs of federal interference with state activities, but the sum of the costs of federal interference and those of noninterference in particular cases.

I. Timing. - The clear line drawn in Steffel between cases in which state proceedings were and were not pending when the federal complaint was filed was smudged by the Supreme Court's decision in Hicks $v$. Miranda. ${ }^{158}$ Miranda, the owner of an adult theater, brought an action against California authorities who had

${ }^{157} 365$ U.S. 167 (I96I).

158422 U.S. 332 (1975). 
seized several copies of an allegedly obscene film and initiated prosecutions against two theater employees. ${ }^{159}$ Immediately after they were served with Miranda's civil complaint, state officials amended their criminal information by adding him as a defendant. ${ }^{160}$ A three-judge district court ruled that Younger did not apply because no charges were pending against Miranda when he filed his federal suit. ${ }^{161}$ Alternatively, the court found that there had been a sufficient showing of bad faith to meet the Younger requirements if they did apply. ${ }^{162}$ The district court went on to hold the relevant California statute unconstitutional and to order the return of seized films. ${ }^{163}$

The Supreme Court reversed and held that Younger applies when state proceedings are commenced at any time prior to "proceedings of substance on the merits" in federal court. ${ }^{164}$ Further, it strongly suggested that, even absent the amended criminal complaint naming Miranda, the Younger burden would have to have been met because of the substantial connection between Miranda's interests and those of the employees named in the original criminal complaint. ${ }^{165}$ Finally, the Court rejected the lower court finding of bad faith sufficient to satisfy Younger and said the case should have been dismissed. ${ }^{166}$

In analyzing the timing rule set forth in Hicks, it is useful to observe that a plaintiff seeking federal declaratory or injunctive relief against a statute may be in one of three situations. First, he may want to embark on a course of conduct that is prohibited by an arguably invalid state law. This plaintiff poses no timing problem of the sort faced in Hicks because a state cannot prosecute him for something he has yet to do. Steffel assures him a federal forum and subsequent cases do nothing to deprive him of it. If his claim is justiciable he can get a declaration of his rights, and, in a proper case, an injunction may be available as well. ${ }^{167}$

Second, a plaintiff may have already engaged in forbidden but arguably protected conduct which he has no intention of repeat-

${ }^{159}$ Id at at $334-38$.

${ }^{160}$ Id. at $338-39$.

${ }^{161} \mathrm{Id}$. at 340 .

${ }^{162}$ Id; see p. 1323 infra.

${ }^{163} 422$ U.S. at 340.

${ }^{164}$ Id. at 349.

${ }^{165}$ Id. at $348-49$. For a discussion of this derivative preclusion theory, see pp. I314-1 7 infra.

${ }^{166} 422$ U.S. at $350-52$.

${ }^{167}$ See pp. 1290-92 supra. The Court treated the plaintiff in Steffel as though he fell in this category and did not emphasize the fact that he had violated the law in the past and had been warned not to do so again. Steffel v. Thompson, 415 U.S. $45^{2}, 455-56$ (I974). But, of course, whatever the prior events, a claim can be styled as one for future relief. 
ing. Such a plaintiff does not pose a compelling case for declaratory relief. He faces no difficult decisions whether to engage in future conduct and risk penalties. His uncertainty relates only to the consequences of past acts. ${ }^{168}$ If he is prosecuted, he will have a forum in which to assert his federal rights. If he is not prosecuted, he will have no federal rights to assert. While it may not be necessary or possible for a court to weed out such plaintiffs ${ }^{169}$ their situation appears neither to mandate special federal solicitude nor to pose serious problems with the Hicks rule.

The third and most difficult case is the intermediate one in which the plaintiff has engaged in the past and wishes to engage in the future in conduct that is prohibited by an arguably invalid law. Prior to the filing of criminal charges, such a plaintiff has the same compelling need for certainty as the plaintiff in the first situation. He looks, in short, like Steffel. Yet after charges have been filed, that plaintiff is transformed into one closely resembling the plaintiffs in Younger and Samuels. Hicks addresses the question whether prosecutors should be able to force plaintiffs who have violated the law into the Younger mold despite their own efforts to stay in the Steffel one.

Justice White's opinion for the majority provides little argumentation for the Hicks result beyond the remark that any other outcome would "trivialize" Younger. ${ }^{170}$ Indeed, it is an opinion remarkable in part for the absence of any effort to identify and weigh the competing interests. The result, however, appears consistent with the concerns underlying Younger, although it may suggest some change in emphasis.

The only difference between Miranda and the plaintiff in the paradigm Younger situation is the historical fact that he filed in federal court before the prosecutor filed against him. ${ }^{171}$ That distinction may reduce the danger that federal adjudication in a Hicks-type case would be seen as an affront to state courts. In Younger, allowing the federal court to hear the case would have been a major departure from the normal course of criminal prosecutions. The magnitude of that departure and the absence of other justifications might have led to an inference that doubts

${ }^{168} \mathrm{He}$ either will or will not be prosecuted and, if he is, he either will or will not prevail on the merits. It might be argued that his interest in repose justifies declaratory relief. Perhaps that is so, but it certainly does not compel it. It is difficult to see why his repose interest cannot be satisfied by the applicable statute of limitations.

${ }^{169}$ They can conceal their status merely by alleging that they will again engage in the forbidden but arguably protected conduct.

${ }^{170} 422$ U.S. at 350.

${ }^{171}$ The relationship between Miranda and the state court defendants is not considered here. For a discussion of this problem, see pp. 1314-16 infra. 
about the competence of state courts led to the federal adjudication. Such an inference is less likely when a federal court is permitted to retain a case which was properly filed under Steffel, particularly when it has invested resources in the case. In other words, commencement of the federal suit begins to provide and investment in that suit strongly reinforces - a visible nonderogatory reason for permitting the district court to retain the case.

To the extent that an affront to state courts is unlikely, the Hicks result seems to suggest an increased emphasis on the concerns underlying the preference for criminal over civil forums because they are the forum allocation factors uniformly present in Hicks and absent in Steffel. Relegating Miranda to a state criminal trial before substantial federal involvement in the case will conserve judicial and prosecutorial resources, hasten penalties for conduct that can be prohibited, and encourage compliance with the law. Indeed, it is the course that probably would be followed in a unitary system. ${ }^{\mathbf{1 7 2}}$

The difficulty with the Hicks situation, though, is that any rule can create what amounts to a race to the courthouse ${ }^{173}$ by parties seeking to take advantage of that rule. If the date of filing is determinative, plaintiffs are likely to hurry to federal court to forestall state prosecutions. And if the state prosecutors can force dismissal by filing charges subsequently, they often will do so, since there is every reason to assume that they will prefer prosecuting a criminal action in state court to defending a civil one in federal court. ${ }^{174}$ While giving the prosecutor the advantage may be an appropriate application of Younger during the period immediately after the federal suit is filed, it clearly becomes less so as the passage of time and the expenditure of federal judicial resources reduce whatever affront is possible, impose interim burdens on the plaintiff, ${ }^{175}$ and create a situation in which dismissal would waste rather than conserve everyone's resources.

This problem is only partially answered by the Hicks rule

${ }^{172}$ Superimposing a federal-state system upon the concerns that would ordinarily prevail in a unitary system adds reasons both for greater and for less deference. The former are the federalism concerns discussed previously. See pp. II75-90 supra. The latter include the values underlying § 1983, doubts about the efficacy of state courts, and a related desire for forum choice. See pp. 1167-75 supra.

${ }^{173}$ Hicks v. Miranda, 422 U.S. 332, 354 (1975) (Stewart, J, dissenting).

${ }^{174}$ Id. at 357 .

${ }^{175}$ Where the plaintiff seeks to engage in further conduct, delay may be extremely expensive to him. His need for a relatively swift determination of his rights will generally not be implicated by a federal dismissal immediately after his civil complaint is filed. In sharp contrast, if he has already invested time in the federal proceeding, a dismissal prolongs his uncertainty. 
keying the prosecutor's capacity to secure a Younger dismissal to whether there had been "proceedings of substance on the merits" in federal court. ${ }^{176}$ Whatever the wisdom of the substantive balance struck in Hicks, this appears to be an inappropriate timing formula for realizing it. First, it is ambiguous. Neither a proceeding of substance nor one on the merits is likely to be immediately recognizable as such. ${ }^{177}$ Second, there appears to be no reason that a substantial federal court investment in procedural hearings and rulings - as opposed to those on the merits - should not be sufficient to forestall a Hicks dismissal. ${ }^{178}$ Third, the rule is likely to have an undesirable impact on the course of litigation. Federal courts may be hesitant to invest resources in declaratory judgment actions either because they would just as soon avoid the case and want to give prosecutors ample opportunity to file charges or because they are concerned that the time and effort spent will not be found sufficient on review to escape the Hicks rule.

These problems could be resolved by an alternative timing rule with two triggers. First, a federal court should be permitted to refuse to dismiss under Hicks a case in which it has made a substantial investment, ${ }^{179}$ and a finding that the investment was substantial should be given great deference on appeal. Second, an arbitrary deadline should also be set so that - whether or not there have been substantial proceedings - state officials cannot force dismissal after a known period of time. Such a twofold timing rule would avoid distorting litigation, ease the danger that plaintiffs might be deprived of a forum for longer than necessary, and permit the federal court some flexibility to make a swift investment in pressing cases without fear of dismissal on appeal.

The impact of a Hicks dismissal might be mitigated by permitting plaintiffs to obtain an interim order prohibiting further prosecutions prior to a decision on the plaintiff's constitutional claim in state court. ${ }^{180}$ Such an injunction would not, of course, be proper unless the plaintiff could show a danger of irreparable interim harms. ${ }^{181}$

${ }^{176} 422$ U.S. at 349 .

${ }^{177}$ This point is discussed by Justice Stewart in dissent. Id. at 353 \& n.I. As he observes, the district court in Hicks itself had held proceedings bearing some relationship to the merits: it had denied a motion for a temporary restraining order on grounds that plaintiffs had failed to show a likelihood of success on the merits. Id.

${ }^{178}$ Id.

${ }^{179}$ Whether such dismissal would be on the merits or not is irrelevant.

${ }^{180}$ Interim relief is discussed in The Supreme Court, 1974 Term, 89 HaRv. L. Rev. 47, 165-67 (1975).

${ }^{181}$ Preferable to an injunction, of course, would be a stipulation by the prosecutor that he will pursue but a single test case until the constitutional issue has 
The Supreme Court considered and rejected the possibility of such interim relief in Doran v. Salem Inn, Inc. ${ }^{182}$ Plaintiffs in Doran were three local tavern owners who had in the past offered topless entertainment but ceased doing so when an ordinance prohibiting such entertainment was approved. ${ }^{183}$ In a federal court action under section 1983 , they sought a declaratory judgment that the ordinance was invalid and a preliminary injunction against enforcement of the law pending a decision on the merits. ${ }^{184}$ After the suit was filed, one of the three, M \& L Restaurant, began again to offer topless entertainment and was served with summonses on several occasions. ${ }^{185}$ The lower court granted the preliminary injunction for all plaintiffs. ${ }^{186}$

The Supreme Court affirmed with respect to the two plaintiffs who had remained in compliance until the preliminary injunction was issued. ${ }^{187}$ While he expressed doubts about the propriety of the relief in the particular case ${ }^{188}$ Justice Rehnquist reasoned for the Court that a preliminary order for the two should be tested under normal equitable standards, not Younger ${ }^{189}$ and that the trial court's decision required substantial deference. ${ }^{190}$ With regard to $\mathrm{M} \& \mathrm{~L}$, on the other hand, Justice Rehnquist held that the Younger principles prohibited all relief in federal court whether preliminary or final. ${ }^{191}$ Although his reasoning is not explicit, the two paragraphs dealing specifically with M \& L's claim suggest that, because it was barred by Hicks from seeking any final relief in federal court, preliminary relief was necessarily out of the question as well.

The second proposition does not, however, follow from the

been settled. See, e.g., Byrne v. Karalexis, 40I U.S. 216, 22 I (I97I) (Brennan, J., dissenting) (describing prosecutor's stipulation not to seize film or interfere with future showing pending outcome of trial); Beal v. Missouri Pac. R.R., 3 I2 U.S. 45, 50 (I $94 \mathrm{I}$ ) (suggesting that prosecutor's stipulation to test case creates situation in which plaintiff faces no irreparable harm).

${ }_{182} 422$ U.S. 922 (1975).

${ }^{183}$ Id. at $924^{-25}$.

${ }^{184} I d$. at 924 .

${ }^{185} \mathrm{Id}$. at 925 .

${ }^{186} I d$.

${ }^{187}$ Id. at 930,934 .

${ }^{188} I d$. at 932 ("we regard the question as a close one").

${ }^{189} I d$. at $930,93 \mathrm{I}$. By holding that preliminary injunctive relief is available, Justice Rehnquist provided the federal courts with a tool for evading the Hicks timing rule, see pp. I30I-02 supra, that may mitigate some of its dis?dvantages. A plaintiff who secures a preliminary injunction obviously cannot be prosecuted; and a ban on prosecution removes from the state the capacity to trigger a Hicks dismissal. The interim injunction therefore permits the court to protect its authority over the case.

${ }^{190} 422$ U.S. at $93 \mathrm{I}-32$.

191 Id. at 929 . 
first. Unlike final federal relief, an interim order would not have interfered with the state criminal proceedings, been available in the normal course of that proceeding, delayed punishment for the prior act, or consumed additional judicial and prosecutorial resources. ${ }^{192}$ The forum allocation choice presented by a request for interim relief was between a federal civil remedy and an identical state civil remedy, and Steffel held that the mere hypothetical availability of a parallel remedy via a state civil suit is insufficient to require a Younger dismissal. ${ }^{193}$

To be sure, an interim injunction should not issue as a matter of course. The plaintiff would have to meet the traditional requirements of equity - including a showing of irreparable injury and a substantial likelihood of success on the merits. ${ }^{194}$ The latter requirement may, at first glance, appear peculiar because the federal court would have to make a tentative decision about an issue which it is forbidden from finally resolving. ${ }^{195}$ But an estimate of the likelihood of success need be neither difficult nor intrusive. To the extent that the Court is correct in its assumption that state and federal courts are fungible, the federal court will be perfectly competent to estimate the likely outcome no matter where that outcome is to be determined. And this estimate is unlikely to interfere seriously with state decisionmaking. It is a highly tentative determination and would appear to be a good deal less intrusive than the parallel federal decision on the final merits which Doran explicitly sanctions. ${ }^{196}$

\footnotetext{
192 The statements in text do not go to the standard to be applied to a request for interim relief - the amount of interim harm required to support such relief but rather to the fact that Younger does not bar it in federal court. A plaintiff with a sufficient showing of interim harms has no adequate remedy by way of the criminal trial. If he halts his conduct pendente lite and then prevails at trial, he will not be recompensed for the costs of forgoing desirable conduct. Yet if he continues with that conduct and then loses at trial, he may face substantial cumulative penalties. The plaintiffs in Doran illustrate the dilemma. They were potentially subject to daily and cumulative summonses. Id. at 925 . They alleged that if they were required to cease presenting topless entertainment, they might be driven into bankruptcy. Id. at 932. Such a result, of course, would have rendered an ultimate victory on the merits - whether in a declaratory judgment action or a successful criminal defense - not only inadequate but futile. Younger would therefore seem inapplicable.

${ }^{193}$ See p. I 289 supra.

${ }^{194}$ See generally Injunctions, supra note 40 , at 1056.

${ }^{195}$ In Doran, the federal court actually will decide the final issue as well because, while $M$ \& $L$ was dismissed, the complaints of the other plaintiffs continued in district court. If $\mathrm{M} \& \mathrm{~L}$ had been the only party seeking relief, the peculiarity discussed in text would be more obvious. Then only in a hypothetical later suit might the federal court decide finally the issue about which a request for preliminary relief requires an estimate.

${ }^{196}$ See Doran v. Salem Inn, Inc. 422 U.S. 922, 928 (1975) ("the interest of
} 
While it is not anticipated that there will be many successful pleas for interim injunctions, such relief may sometimes be necessary to accommodate the policies underlying Hicks and Younger with the needs of plaintiffs who cannot afford to halt their conduct or risk the cumulative penalties that might result from continuing it. Making such an accommodation in those cases will be the only way of preserving the constitutional issue which Younger and Hicks say should be decided in state court.

2. The Nature of the State Proceeding. - The Younger doctrine was initially articulated, and seemed most solidly established, in cases where the pending state proceedings were criminal in nature. But it soon became apparent that the concerns underlying Younger carried weight even when a federal district court was asked to enjoin pending state civil proceedings or to decide issues that would otherwise be litigated in the course of such proceedings.

The Supreme Court first addressed the problem in Huffman v. Pursue, Ltd. ${ }^{197}$ and concluded that a Younger showing must be made before a federal court can interfere with state-initiated civil proceedings that are "in aid of and closely related to criminal statutes." 198 The federal plaintiff's predecessor in a leasehold interest had been the defendant in state court proceedings brought under an Ohio law characterizing the showing of obscene films as a publice nuisance. ${ }^{199}$ An unappealed abatement order had been entered in state court requiring that the plaintiff's cinema be closed and the personal property used in it sold. ${ }^{200}$ Plaintiff brought suit under section 1983 seeking an injunction against the state court order. ${ }^{201}$ Reversing a three-judge district court, Justice Rehnquist reasoned for the Court that, just as in Younger, federal interference would intrude on state functions and reflect negatively on the competence of state courts. ${ }^{202} \mathrm{He}$ apparently saw in Younger a broad policy of deference to important state functions that applies whenever state officials have instituted proceedings in state court. In addition, Justice Rehnquist held that Younger applies where a plaintiff has failed to appeal an unfavorable state court decision - thus requiring him to

aroiding conflicting outcomes in the litigation of similar issues, while entitled to substantial deference in a unitary system, must of necessity be subordinated to the claims of federalism in this particular area ...."). The threshold determination of substantial likelihood does not pose a danger even of conflicting outcomes merely that of an incorrect estimate.

${ }^{197} 420$ U.S. 592 (I975).

198 Id. at 604.

${ }^{199} I d$. at $595-98$.

200 Id. at 598 .

${ }^{201}$ Id. at $598-99$.

202 Id. at 604 . 
pursue all appellate remedies once the pendency of state proceedings has triggered the Younger rules. ${ }^{203}$ In support of this position, the Justice noted that once a trial has taken place federal interference would lead to even greater duplication. Such interference would also, he reasoned, deprive states of the function of "overseeing trial court dispositions of constitutional issues." 204

Lower court decisions - both before and after Huffmanhave extended Younger further. ${ }^{205}$ They have held, for example, that a federal court must defer to disbarment proceedings, ${ }^{206}$ civil injunctions issued by state courts, ${ }^{207}$ eminent domain proceedings, ${ }^{208}$ domestic relations litigation, ${ }^{209}$ some administrative proceedings, ${ }^{210}$ and other litigation. ${ }^{211}$

This Term, in Juidice v. Vail, ${ }^{212}$ the Supreme Court extended

${ }^{203}$ Id. at 608-09.

${ }^{204}$ Id. Justice Rehnquist's result appears proper. In effect, the plaintiff sought collaterally to attack the continuing effects of a state court abatement order. A quite different case, of course, is posed when a plaintiff who has in the past been convicted of an offense challenges the future applicability of the statute defining that offense. No requirement of appeal would attach to such a case because the plaintiff would not be seeking "federal intervention in a state judicial proceeding as to which a losing litigant has not exhausted his state appellate remedies," id. at 609. Rather, he would be seeking prospective relief. This was made clear in this Term's decision in Wooley v. Maynard, 45 U.S.L.W. 4379 (U.S. April 20, 1977), which affirmed anticipatory relief notwithstanding prior unappealed state convictions. See note ro3 supra.

${ }^{205}$ A number of Supreme Court Justices apparently favor such an extension. Justice Rehnquist's opinion in Huffman suggested that the Court had created a "civil counterpart" to Younger. Huffman v. Pursue, Ltd., 420 U.S. 592, 6II (1975). Justice White, joined by Chief Justice Burger and Justice Blackmun, argued that Younger should be extended into the civil area in his dissents in Fuentes v. Shevin, 407 U.S. 67, 97-99 (1972), and Lynch v. Household Fin. Corp., 405 U.S. 538, 560-6I (1972).

${ }^{206}$ See, e.g., Anonymous v. Association of the Bar, 5I5 F.2d 427 (2d Cir.), cert. denied, 423 U.S. 863 (1975); Goodrich v. Supreme Court, 5II F.2d 3 I6 (8th Cir. 1975) ; Niles v. Lowe, 407 F. Supp. 132 (D. Hawaii 1976).

${ }^{207}$ See Lynch v. Snepp, 472 F.2d 769 (4th Cir. 1973), cert. denied, 4I5 U.S. 983 (1974). See also Duke v. Texas, 477 F.2d 244 (5th Cir. I973) (injunction tied to criminal statute issued to keep nonstudents from state university campus), cert. denied, 4I5 U.S. 978 (1974).

${ }^{208}$ See Ahrensfeld v. Stephens, 528 F.2d I93 (7th Cir. 1975) (using Younger and abstention doctrines); Sorger v. Philadelphia Redev. Auth., 40r F. Supp. 348, 353-54 (E.D. Pa. 1975) (dictum).

${ }^{209} \mathrm{See}$, e.g., Williams v. Williams, 532 F.2d I20 (8th Cir. 1976).

210 See McCune v. Frank, 52 I F.2d II52 (2d Cir. 1975) (suggesting application to police disciplinary proceeding); Do-Right Auto Sales v. Howlett, 40I F. Supp. ro35 (N.D. Ill. I975); $c f$. Gibson v. Berryhill, 4I I U.S. 564 (I973) (implied in dictum).

${ }^{211}$ See, e.g., Cousins v. Wigoda, 463 F.2d 603 (7th Cir.) (dispute among rival delegations over certification for political convention), stay denied, 409 U.S. I20I (r972) (Rehnquist, Circuit Justice).

21245 U.S.L.W. 4269 (U.S. March 22, 1977 ). 
Huffman and Younger to contempt proceedings initiated by private parties. Plaintiffs, a class of judgment debtors, sought injunctive and declaratory relief against statutory contempt procedures under which the successful creditor could subpoena defaulting debtors to a postjudgment deposition and, when they failed to comply, take steps leading to a court-ordered show-cause hearing and ultimately to a contempt citation punishable by fines and imprisonment. ${ }^{213}$ Writing for the Court, Justice Rehnquist first denied standing to all plaintiffs save those already subject to contempt orders and thus in imminent danger of incarceration. ${ }^{214}$ He then held their claims barred by Younger because they could have raised their due process objections to the proceedings in state court if they had complied with orders to attend show-cause hearings. ${ }^{215}$ Citing the broad federalism language in Younger, Justice Rehnquist stressed the importance to the state of exacting compliance with court orders. ${ }^{216}$ He suggested that federal interference would offend this interest and reflect negatively upon the state courts. ${ }^{217}$

The implications of the Vail decision are far from clear. While Justice Rehnquist held that Younger and Huffman "are not confined solely to the types of state actions which were sought to be enjoined in those cases," ${ }^{218}$ he explicitly eschewed full consideration of "the applicability of Younger to all civil litigation." 219 Indeed, contempt proceedings of the type at issue in Vail form a poor basis for further generalizations and may in fact be sui

${ }^{213} I d$. at 4270.

${ }^{214} I d$. at $427 \mathrm{x}$. The certified class was made up of "all persons who have been or are presently subject to the civil contempt proceedings." Id. at 4270 . Justice Rehnquist reasoned that those who had been incarcerated and released and paid their fines "no longer had a live controversy." Id. at $427 \mathrm{I}$. He noted that there had been no allegations that the plaintiffs thus excluded might be subject to future contempt orders. Id. at 427 I \& n.9.

215 Id. at 4272 \& n.r4. The Court's reasoning seems to divide the due process issue into two questions: (I) whether the state proceedings were adequate as a prelude to contempt citations, incarceration, and fines; and (2) whether they were adequate to consider the due process issues raised by inquiry ( $\mathrm{I}$ ). Justice Stevens concurred in the opinion on non-Younger grounds. Id. at 4274-75. He openly, but briefly, reached the merits and approved the state procedures. In effect, he concluded that the two inquiries suggested above are really one, that the state proceedings comported with due process, and therefore that the plaintiffs could constitutionally be relegated to them. Id. at 4275 . He felt that the nature of the case made Younger "inappropriate" because a decision to relegate the plaintiff to his state proceedings necessarily required a decision that those proceedings were adequate. Id. This approach may suggest the need to recognize a category of cases in which Younger dismissal is an improper tool. See pp. 1320-2I infra.

${ }^{216} 45$ U.S.L.W. at $427 \mathrm{I}-72$.

${ }^{217} \mathrm{Id}$. at 4272 .

218 Id. at 4271 .

${ }^{219}$ Id. at 4272 n.I3 (quoting Huffman v. Pursue, Ltd., 420 U.S. 592, 607 (1975)). 
generis. While not part of the normal criminal process, they lead to penal sanctions of a type rarely imposed except to further important state interests. While triggered by private parties, they impose few burdens without the significant involvement of the judge. While often promoting the interests of private litigants, they also serve the public interest by protecting the smooth functioning of the court system. Accordingly, notwithstanding their civil, private posture, these contempt proceedings are in significant respects akin to the more public, prosecutorial, enforcementoriented proceedings held to support Younger dismissals in earlier cases. $^{220}$

Three possible stopping points suggest themselves as one attempts to answer the question left open in Vail and define the types of state proceedings that should trigger the Younger rule. First, one might advocate a retreat to the line drawn in the $197 \mathrm{I}$ decisions and limit the doctrine to pending criminal proceedings. The rejection of this line in Huffman, however, seems justified. While nominally civil, the purpose of the action was to enforce substantive policies to which, wisely or not, the state attached importance. Permitting a federal court to determine the validity of the state statutory scheme would delay effectuation of those policies, drain prosecutorial resources, cause some duplication of judicial effort, and perhaps impugn the competence of state courts. It would, in short, run precisely counter to the forum allocation preferences held determinative in Younger.

To be sure, as Justice Brennan argued in his Huffman dissent, ${ }^{221}$ criminal charges, unlike a civil action, can be brought only after a number of formal procedural steps have been taken. ${ }^{222}$ But the safeguards to which he refers - "arrest, charge, information or indictment" 223 - are likely to be but minor checks on the dangers of frivolous or bad faith prosecution. ${ }^{224}$ And, whether

220 Therefore, at least as a matter of logic, the Vail decision does not support an extension of Younger to civil cases generally. But in his fiery dissent, Justice Brennan asserted that the question of further extensions had been reserved in name only, 45 U.S.L.W. at $4273 \mathrm{n} . *$, assailed the decision as a "plain refusal to enforce the congressional direction" underlying $\S \mathrm{r} 983$, id. at 4273 , and insisted that Younger had no application to suits between private parties, id. at $4273-74$.

${ }^{221} 420$ U.S. at $6 \mathrm{I}_{3}-\mathrm{I} 8$.

${ }^{222} I d$. at 6r5. Justice Rehnquist's majority opinion considered the somewhat different argument that the absence of habeas corpus relief in civil proceedings renders Younger inappropriate. Justice Rehnquist questioned the "unarticulated major premise" that every litigant who asserts a federal claim is entitled to the "luxury" of a federal forum, and asserted that, if such a right existed, it should not at any rate be asserted prior to the completion of all state court proceedings.

Id. at $605-06$.

${ }^{223}$ Id. at 6I5.

${ }^{224}$ Whether criminal or quasi-criminal, the state proceedings are invoked by state officials - perhaps the identical state officials. And there is no reason to 
the state proceeding is civil or criminal, the Younger doctrine should be able to respond to bad faith prosecutions through its exceptions, not through coverage rules.

A second possible stopping point for the Younger doctrine would be the Huffman rule - that the state proceeding must be in aid of and closely related to a criminal statute. ${ }^{25}$ Yet it is not clear that a state's purely civil enforcement actions are less deserving of deference, less important, or less presumptively valid than its quasi-criminal actions. In either case, state officials are using the state courts to enforce substantive state policies, and federal interference will delay enforcement, consume resources, and give rise to an affront to state courts.

A third effort to contain the Younger doctrine would hold that it applies to any state judicial proceeding brought by the state to enforce its laws and policies, but not to civil suits initiated by private parties. Keying the application of Younger to the state's involvement in the proceedings has some appeal. ${ }^{226}$ Where the state court action was brought by a private party, no executive or administrative resources will have been committed to it. In addition, any presumption that state authorities by and large act in good faith would clearly not apply to private parties who could seek to use a state's judicial machinery for harassment purposes. ${ }^{227}$ Further, when the state leaves certain substantive policies to private enforcement, it may well have made a judgment that those policies are less pressing than others to which it devotes substantial executive resources. Accordingly, the delays that might result from permitting federal interference would appear less problematic. Finally, while there remains tension between state and federal courts, and hence some danger of affront, that danger may be less great during the early stages of private civil litigation because it often will not be clear which constitutional issues will be litigated in the state court proceedings. ${ }^{228}$ This analysis suggests that, at least initially, there is a

assume that it will be more difficult for a hypothetical wanton official to make out charges or an information and order an arrest than to file a public nuisance action.

${ }^{225} 420$ U.S. at 604 .

${ }^{226}$ This view is urged in Comment, Post-Younger Excesses in the Doctrine of Equitable Restraint: A Critical Analysis, 1976 Duke L.J. 523, 558-59.

${ }^{227}$ It is in the private litigation area that the dangers referred to by Justice Brennan in his Huffman dissent seem most serious. See Huffman v. Pursue, Ltd., 420 U.S. 592, 615 (1975) ("To deny . . . the potential federal plaintiff a federal forum . . . is obviously to arm his adversary ... with an easily wielded weapon to strip him of a forum and a remedy that federal statutes were enacted to assure him.").

${ }^{228}$ Insofar as affront responds to departures from the normal course of litigation - from a federal decision on issues obviously pending before a state court - 
good reason not to extend Younger into the area of private civil litigation. But the picture changes somewhat as the state court becomes increasingly involved in a lawsuit. Duplication of effort becomes more serious and affront more likely as the state judge nears a decision on the constitutional claim the state defendant would like to assert in federal court.

While the problem of overlapping private state and federal suits has generally been dealt with under other rubrics, ${ }^{229}$ it has been suggested that Younger should apply in this area. ${ }^{230}$ If so, the preceding discussion suggests that a timing rule different from the one set forth in Hicks is necessary. Where no state executive resources have been committed to a case and there is less danger of affront to state courts, the determinative factors in the Hicks result are absent and Younger should not defeat a plaintiff's choice of a federal forum for a federal constitutional claim, even if a private action has been filed against him in state court. ${ }^{231}$ In contrast, when it is clear that the state judge has made a substantial investment in the case, is about to decide the plaintiff's constitutional question, or has already decided it, Younger could be held to mandate federal restraint in the absence of recognized exceptions.

By relating the applicability of Younger to the state court's investment in the proceedings, such an inverse version of the Hicks timing rule would confine Younger to those private civil suits in which it seems more nearly relevant. The practical effect of such a rule might in fact be relatively minor. The federal court might abstain or stay proceedings even if Younger were not applied. ${ }^{232}$ And the state court defendant who seeks federal

a private civil proceeding would appear to pose fewer problems. It generally is more freewheeling in structure and uncertain in scope; as a result, especially in the period shortly after the filing of the complaint, it is unlikely that a federal decision on an issue will have the directly intrusive quality present in the paradigm fact situation.

${ }^{229}$ See, e.g., HART AND Wechsler, supra note 45, at 1257-61; Note, Stays of Federal Proceedings in Deference to Concurrently Pending State Court Suits, 60 Colum. L. Rev. 684 (ig6o); ALI, Study of the Division of Jurisdiction Between State and Federal Courts $\$$ I37I (f) ( 1969 ).

${ }^{230}$ See, e.g., Rizzo v. Goode, 423 U.S. 363, 380 (I976) (dictum broadening $H u f f-$ man) ; Lynch v. Household Fin. Corp., 405 U.S. 538, 56r (1972) (White, J., dissenting with Burger, C.J., \& Blackmun, J.) (urging applicability of Younger to civil cases).

${ }^{231}$ This is not to say that the federal court may not conclude that it should stay its hand pending a state determination. The point is that the firm categorical rule of Younger should not apply.

${ }^{232}$ See, e.g., Colorado River Water Conservation Dist. v. United States, 424 U.S. 800 (1976); Brillhart v. Excess Ins. Co., 316 U.S. 491, 494-95 (1942); Puerto Rico Int'l Airlines, Inc. v. Silva Recio, 520 F.2d I342 (Ist Cir. I975) 
declaratory relief under section 1983 against the private plaintiff in the state suit may be faced with serious state action problems where his claim is triggered only by the filing of a private complaint. ${ }^{233}$

3. Derivative Preclusion. - The parties prevented from raising claims in federal court in the paradigm Younger situation were themselves the defendants in the pending state court proceedings. In Hicks, ${ }^{234}$ however, the Supreme Court strongly suggested that a Younger dismissal might be required where the federal plaintiff, although not himself the target of state proceedings, controls the defense to those proceedings, could adequately assert his constitutional claims within them, and seeks in federal court to abort them. ${ }^{235}$ While it ultimately did not rely on this notion of derivative preclusion, ${ }^{236}$ the Court asserted that "[a]bsent a clear showing that appellees . . . could not seek the return of their property in the state proceedings and see to it that their federal claims were presented there, the requirements of Younger v. Harris could not be avoided . . . ." ${ }^{237}$ Similarly, other Justices have suggested that an organization whose asserted claims and rights are derived from its members would be precluded from challenging a state's prosecution of its members unless it could make the special showing required by Younger. ${ }^{238}$

It is submitted, however, that any extension of Younger to nonparties via a derivative preclusion theory is unjustified. It should be observed at the outset that some duplication and overlap is inevitable in a federal system. Steffel and Doran leave no doubt that it is perfectly proper for state and federal courts to

(holding that Younger does not apply to privately initiated state civil proceedings but that exercise of jurisdiction was matter of discretion for district court).

${ }^{233}$ See Henry v. First Nat'l Bank, 444 F.2d 1300, 1307-12 (5th Cir. 197I) (relying upon New York Times Co. v. Sullivan, 376 U.S. 254 (I964), and Shelley v. Kraemer, 334 U.S. I (I948), for dismissal on grounds that there is no state action until state courts have acted), cert. denied, 405 U.S. I0I9 (1972); Stevens v. Frick, 372 F.2d 378, 381 (2d Cir.), cert. denied, 387 U.S. 920 (1967); Gras v. Stevens, 415 F. Supp. II48, II52 (S.D.N.Y. I976).

This approach to state action does not seem inevitable. Cf. Lindsey v. Normet, 405 U.S. 56 (1972) (reaching merits without discussion of state action in suit filed by private tenant against private landlord who had threatened to invoke state summary eviction procedures).

${ }^{234}$ Hicks v. Miranda, 422 U.S. 332 (1975).

${ }^{235} I d$. at $348-49$.

${ }^{236}$ The Court's holding in Hicks was based upon the new timing rule it advanced. See p. 1302 supra. Accordingly, the force of its discussion of what this Section calls derivative preclusion is less than clear.

${ }^{237} 422$ U.S. at 349 . The Court also discussed derivative preclusion in Doran v. Salem Inn, Inc., 422 U.S. 922, 928-29 (I975).

${ }^{238}$ See Allee v. Medrano, 416 U.S. 802, 830-32 (1974) (Burger, C.J., concurring and dissenting, joined by White \& Rehnquist, JJ.). 
decide identical issues, nearly simultaneously, at the behest of legally unrelated parties. ${ }^{239}$ The inefficiencies and conflicting decisions that result are costs of federalism, justified by the need to accommodate the interests of federal plaintiffs in Steffel-type situations with those of the state in Younger-type cases. Even when the federal plaintiff is the state defendant, he may be asserting what to him is a distinguishable right, one that goes to the future rather than the past. Younger precludes such a plaintiff's federal suit in those situations in which there is little reason to doubt that his state defense will provide an adequate remedy for both facets of his claim. Where the federal plaintiff is not the state defendant, there is likely to be a greater divergence between his claim and that at issue in the state proceedings, as well as a good deal less reason to rely upon the adequacy of a state court defense. First, unless the nonparty federal court plaintiff clearly cannot engage in the future in conduct barred by the arguably invalid statute he challenges,${ }^{240}$ it will be impossible to assume away the Steffel-like facet of his complaint his own desire for certainty as to his future rights. That the fulfillment of that desire will affect, perhaps seriously, someone's pending proceeding is not grounds for dismissal under Steffel or Doran. ${ }^{241}$ Second, permitting the nonparty's federal suit will not interfere with state prosecutorial decisions or consume state executive resources in cases where the nonparty could have been named in the criminal complaint. A rule permitting his federal suit without regard to Younger may encourage state officials to charge more parties at the outset. ${ }^{242}$ More likely, it will simply encourage the state to do what it did in Hicks - amend the criminal information after the 1983 suit is filed. ${ }^{243}$ Either way,

${ }^{239}$ See Doran v. Salem Inn, Inc., 422 U.S. 922, 927-28 (1975) (conceding that parallel and potentially contradictory state and federal suits are necessary result of a federal system); Steffel v. Thompson, 4I5 U.S. $45^{2}$ (1974) (permitting federal declaratory relief for plaintiff whose erstwhile companion violated the challenged state law and faced state prosecution). See also Roe v. Wade, 4 Io U.S. II3 (I973).

${ }^{240}$ In such a case he might well be unable to show the requisite case or controversy in any event. See pp. I292-r301 supra.

${ }^{241}$ In Hicks, the Court seemed to suggest that the intentions of the nonparty federal plaintiff were important. 422 U.S. at 348-49 ("[T]he federal action sought to interfere with the pending state prosecution."). It is of course true that it is easier to assume an identity of interests between parties and nonparties where such an intention is evident. But no rule keyed to the intent of the federal suit would be workable because pleadings could simply be altered to seek apparently neutral declaratory relief.

242 It seems unlikely that the threat of a federal action would encourage state officials to file charges against improper parties who could not conceivably be convicted. But if it did so, that conduct would suggest the kind of bad faith that is sufficient to overcome the Younger burden. See pp. 1323-24 infra.

${ }^{243}$ Hicks v. Miranda, 422 U.S. 332 (1975). As in note 242 supra, where 
the state has considerable latitude to avoid any adverse consequences that might stem from allowing the nonparty's federal complaint to proceed.

Third, because of the considerations discussed in the preceding paragraph, the class of persons most likely to be precluded under a derivative theory will be made up of those who could not have been named as criminal defendants either at the outset or after the civil rights action was filed. One might well wonder whether a person who could not have been named in the state information has a genuine opportunity to assert his interests by virtue of whatever control he exercises over the criminal defense put on by someone else. Fourth, it might more generally be undesirable to encourage nonparties to dictate strategy to criminal defendants. It is quite possible that the defendant will have divergent interests. For example, he might want to enter a plea while the nonparty would prefer to litigate a constitutional claim. ${ }^{244}$ Conversely, the nonparty might want the defendant to plead out and bring an end to the state proceeding so that he can get swiftly into federal court. In short, the separate rights of separate persons would be improperly and haphazardly combined by a derivative preclusion rule. ${ }^{245}$

prosecutors add the nonparty to the indictment merely to forestall the federal suit without any intention or reasonable expectation of securing a conviction, there would be grounds for an exception. Hicks suggests that such a showing must include more than the mere fact that charges were filed after the plaintiff filed a $\$$ I983 suit. See id. at 350-5 I \& n.I9 (reversing lower court determination that plaintiff had been added to the state criminal complaint in retaliation for instituting federal court litigation and therefore was victim of bad faith prosecution).

${ }^{244}$ Litigating the claim - or having it litigated - in the state court might provide the nonparty with a free try at his constitutional assertion prior to instituting a federal action.

245 The problem may be especially severe where the federal plaintiff is an organization or institution that is asserting the rights of a group of persons perhaps including the state court defendant. In Allee v. Medrano, 416 U.S. 802 (1974), the Court failed to reach the applicability of Younger to a challenge to state statutes allegedly used in a systematic official campaign to crush union organizing efforts. Id. at 816-21. The class action suit was brought by union members and the union organizing committee. In their concurring and dissenting opinion, Chief Justice Burger and Justices White and Rehnquist urged that a Younger showing would have to be met if any of the plaintiffs were being prosecuted, id. at 830-3I, and that the union would not be able to aggregate the harms facing its members for purposes of making such a showing, id. at 838-39. Rather, they concluded that the union could make the required showing only if the state court defendant could have done so. Id. Both suggestions would appear to ignore the fact that the organization can assert claims and rights beyond those of the individual defendant. See, e.g., NAACP v. Button, 37 I U.S. 415, 428 (1963); NAACP v. Alabama, 357 U.S. $449,462-63$ (1958) ; Citizens for a Better Environment, Inc. v. Nassau County, 488 F.2d 1353, 1361 (2d Cir. 1973) (Younger does not bar organization's challenge to antisolicitation ordinance notwithstand- 
It is not contended here that precluding only actual parties corresponds exactly with the concerns to which Younger responds. There may, to be sure, be cases in which none of the aforementioned difficulties is likely and, despite his different identity, the federal plaintiff closely resembles the plaintiff in the paradigm fact situation. ${ }^{246}$ The question posed here is not whether such cases exist, but whether the general problem is best addressed by a derivative preclusion rule - which either will require a rather close investigation in every case or will sweep too broadly - or by a party preclusion rule that would key the applicability of Younger to whether the state had decided to prosecute the federal plaintiff. The second rule would appear to be preferable.

4. The Nature of the Plaintiff's Claim. - The preceding discussion has focused upon plaintiffs seeking declaratory and sometimes injunctive relief from pending state proceedings on grounds that the statute being applied in those proceedings is unconstitutional. It has sought to develop a series of rules for defining the coverage of the Younger doctrine in such situations. But even when those requirements are met, a federal plaintiff who is also the target of state proceedings is properly barred only from asserting a fairly specific category of federal claims. A host of possible suits by such a plaintiff would simply have no impact on or relation to any state litigation in which he is embroiled. Other suits, although perhaps related to the state proceeding or to the events which gave rise to that proceeding, will not raise the specter of affront to state courts, duplication of judicial effort, consumption of executive resources, and interference with state enforcement that gives vitality to the Younger preclusion requirement. Accordingly, a final coverage parameter must be considered - one that seeks to distinguish among claims made by federal plaintiffs and to isolate the few that, like the prayers for injunctive and declaratory relief in the paradigm fact situation, present the peculiar array of factors that justifies

ing pending proceedings against its members because the organization's interest lies in the future.).

${ }^{246}$ Lower courts have sought to identify such cases and apply Younger to them. See, e.g., Grandco Corp. v. Rochford, 536 F.2d 197, 205 \& n.8 (7th Cir. 1976) (prosecution of theater manager precludes suit in federal court by theater); Gajon Bar \& Grill, Inc. v. Kelly, 508 F.2d 1317 (2d Cir. 1974) (Younger applied to suit by tavern and manager when tavern employees, including manager, were targets of state proceedings). See also id. at ${ }^{3} 323$ (Kaufman, C.J., concurring) (expressing concern about extending Younger to "cases where an institutional plaintiff exists primarily for the expression and defense of the right sought to be protected ... [ [or where] no individual could adequately safeguard a widely held interest"). 
overriding a plaintiff's choice of forum and relegating him to his state proceeding.

It is useful to begin with the easy case posed by the prayers for declaratory and injunctive orders in the paradigm fact pattern. At the risk of being somewhat repetitive, they have the following characteristics: ( I ) the federal court is asked to make a decision that would directly affect, and might well abort, the pending state proceeding or some facet of it; (2) there is an opportunity to raise in state court the issue sued on in federal court; (3) that opportunity arises in the normal course of the state proceeding and the relevant constitutional question is one that would otherwise (and might still) be raised during that proceeding; (4) a favorable decision in state court would generally remedy the asserted constitutional violation. ${ }^{247}$

These characteristics, in turn, relate directly to the harms Younger and its progeny seek to avoid. Without ( $r$ ) there is no major interference with the state's enforcement of its substantive policies. Without (2) and (3) there is unlikely to be any affront to state courts. Without (2) and (4) the federal plaintiff would not have the adequate remedy which serves as a predicate for a Younger dismissal. And without (3) the dismissed federal plaintiff would in effect be required to initiate state litigation - to act like a plaintiff rather than a defendant in state court - which, under Steffel, is not required and would run counter to the command of Congress.

In contrast, where the federal complaint does not raise issues identical to those that would have to be decided in the state proceeding, or where it seeks relief not substantially equivalent in effect to that available by way of a successful state court defense, the Younger balance would seem inapposite. Such an approach may be illustrated by the following examples.

First, in Fuentes $v$. Shevin, ${ }^{248}$ the Supreme Court struck down prejudgment repossession procedures that had been challenged in a 1983 suit filed while the federal plaintiffs were the defendants in state court replevin actions. ${ }^{249}$ Notwithstanding the dissent's argument to the contrary, ${ }^{250}$ federal relief clearly was not barred

${ }^{247}$ Closely analogous to the claims for relief against state statutes in the paradigm fact situation would be a complaint seeking a ruling on an issue of criminal procedure that would otherwise come up in the course of the state court trial. See Cleary v. Bolger, 37I U.S. 392 (I963); Stefanelli v. Minard, 342 U.S. II7 (I95I). While it purported to apply principles of equitable restraint in declining to order that evidence be suppressed in state court, id. at 123-24, the force of the latter case is softened by the fact that it arose before Mapp v. Ohio, 367 U.S. 643 ( 1963$)$, had required state courts to exclude illegally obtained evidence.

248407 U.S. 67 (1972).

${ }^{249}$ Id. at $96-97$.

${ }^{250}$ Id. at 97-99 (White, J., dissenting, joined by Burger, C.J., \& Blackmun, J.). 
by the Younger cases. The federal suit on the validity of prejudgment repossession had, at most, an indirect and relatively minor impact on the underlying action for debt. ${ }^{251}$ It considered distinct legal and factual issues and its outcome turned on no issue that would have come up in the normal course of the state action. In addition, a successful defense in the state court suit would not have provided the federal plaintiffs with a remedy for the unconstitutional deprivation of their property during the pendency of the state litigation. ${ }^{252}$ Finally, while the federal plaintiffs might, to be sure, have sought relief in a state civil action, Steffel makes clear that that course is not required..$^{253}$

Second, in Gerstein v. Pugh, ${ }^{254}$ the Court required state authorities to provide preliminary hearings ${ }^{255}$ in a suit filed by persons who were the targets of pending state criminal prosecutions. ${ }^{256}$ For reasons analogous to those discussed in the foregoing paragraph, the Court was correct in recognizing that Younger posed no obstacle to relief. ${ }^{257}$ Any impact on the underlying prosecution was incidental. ${ }^{258}$ Deciding the con-

${ }^{251}$ The majority distinguished Younger with the brief statement that neither plaintiff "sought an injunction against any pending or future court proceedings as such. . . Rather, they challenged only the summary extra-judicial process of prejudgment seizure of property to which they had already been subjected." Id. at $7 \mathrm{I}$ n.3.

The only likely effect on the state proceeding would result from the substantive federal court ruling striking down the summary procedures and thereby perhaps making it more difficult for creditors to repossess and collect. But that consequence, while perhaps relevant to the due process issue, see id. at roo (White, J., dissenting), has nothing to do with the Younger inquiry into the proper forum.

${ }^{252}$ Indeed, the case was explicitly concerned with the plaintiffs' asserted property interest in possession of the chattels pending a resolution of the underlying state action. Id. at $84-86$. That interim claim would have been washed out at the conclusion of the state suit. See also Lynch v. Household Fin. Corp., 405 U.S. 538 (1972).

${ }^{253}$ It should be observed that the Fuentes example is in many respects similar to that posed by a request for interim relief against cumulative prosecutions pending the resolution of constitutional issues in the course of a state trial. See pp. 1305-07 supra. While not as obviously distinct or collateral as the due process issues raised in Fuentes, an interim relief claim may be resolved independently of anything more than a tenuous estimate about the merits and will not interrupt the state's adjudication of those merits.

${ }^{254} 420$ U.S. 103 (1975).

${ }^{255} \mathrm{Id}$. at I16-19.

${ }^{256} I d$. at 105.

${ }^{257}$ The Court considered and rejected the possible application of Younger on grounds that "the injunction was not directed at the state prosecutions as such, but only at the legality of pretrial detention without a judicial hearing." Id. at 108 n.9 (citing Conover v. Montemuro, 477 F.2d 1073, 1082 (3d Cir. 1973)).

${ }^{258} \mathrm{As}$ in Fuentes, the substance of the due process holding may have an effect on state proceedings - perhaps by imposing a stage in the proceedings at which 
stitutionality of prolonged pretrial detention without a hearing involved none of the factual and legal issues central to the criminal prosecution. A successful defense to the state charges would not have been an adequate remedy for unconstitutional pretrial confinement. And the normal course of the state procedures therefore provided no opportunity to complain of invalid incarceration. Indeed, it was the absence of such an opportunity that formed the crux of the plaintiff's complaint. Accordingly, Younger is simply inapposite to the Gerstein situation.

Third, certain challenges to the procedures to which the plaintiff is being subjected in state court may defy analysis in Younger terms because it will be impossible to relegate the plaintiff to his state remedies without passing upon their constitutionality. In the Vail case, ${ }^{259}$ for example, the New York contempt procedures were attacked in part on grounds that there was no adequate notice of the court-ordered show-cause hearing that preceded the issuance of a contempt citation. ${ }^{260}$ By holding for the majority that that hearing provided the plaintiffs with an opportunity to raise their claims adequate to support a Younger dismissal, ${ }^{261}$ Justice Rehnquist seems to have held as well that the notice of that hearing met constitutional requirements. For only if a plaintiff was properly notified could the show-cause hearing provide an adequate opportunity to raise due process objections. ${ }^{262}$ The broad point is that Younger will not always

evidence can be developed or by requiring the state to commit more resources to procedures. But any such impact goes to the constitutional standard to be applied, not to the applicability of Younger. See Pugh v. Rainwater, 483 F.2d 778, 78I-82 (5th Cir. 1973), aff'd in part and rev'd in part sub nom. Gerstein v. Pugh, 420 U.S. I03 (I975).

${ }^{259}$ Juidice v. Vail, 45 U.S.L.W. 4269 (U.S. March 22, 1977); see pp. 1309-12 supra.

${ }^{260}$ The specific due process claims are discussed in the district court opinion. See Vail v. Quinlan, 406 F. Supp. 95 I, 959-60 (S.D.N.Y. 1976) (three-judge court). In addition to the claims that notice of the severe consequences of failure to attend a state show-cause hearing was inadequate, plaintiffs alleged that the procedures were violative of the due process clause because they permitted imprisonment without an actual hearing, failed to provide assigned counsel, and imposed punitive fines. Id. at 959 .

${ }^{261} 45$ U.S.L.W. at 4272

${ }^{262}$ It may be necessary in this regard to distinguish between the two plaintiffs held to have standing in Vail. Id. at 4270-7I. One of them, Ward, had apparently failed to attend the state show-cause hearing and was subject to an order of contempt. Id. Only the presence of an outstanding restraining order prevented his incarceration. Id. at $427 \mathrm{I}$. The other plaintiff, Rabasco, had received an order to show cause but had not yet been held in contempt when the lower court restraining order shielded him from further state proceedings. Id. It might be argued that a dismissal as to Rabasco included no hidden substantive decisions save one that the state forum was competent to decide the validity of its own procedures. Ward, however, had missed his only opportunity to appear in state court prior to 
provide a way to avoid a decision on the merits. Just as dismissal in the paradigm case necessarily included a decision that being prosecuted was not itself a constitutional deprivation, ${ }^{263}$ so dismissal in cases raising procedural attacks may include - and therefore should recognize - a decision on the merits of some claims. ${ }^{264}$

Fourth, the observation in Younger and subsequent cases that dismissal is not mandated in cases of harassment ${ }^{265}$ responds in part to the concerns discussed in this subsection. Where the plaintiff seeks prospective relief against alleged illegal arrests, searches, seizures, and similar official conduct, the pendency of criminal proceedings may be irrelevant. ${ }^{266}$ A successful defense to state charges would not prevent future illegal conduct, and the plaintiff's federal complaint will raise issues that - like those in Gerstein and Fuentes - are collateral to the pending state proceeding. Because the relief sought and the issues raised are not cognizable in the state proceeding, no extraordinary Younger showing is required to avoid dismissal. ${ }^{267}$

incarceration. Hence, dismissal meant that he might be incarcerated after failing to attend the show-cause hearing. That in turn seems necessarily to include a substantive decision that the notice he received of that hearing was adequate under the due process clause. Justice Stevens, in his concurring opinion, recognized that the Vail result required a substantive decision, although he failed to distinguish between the two plaintiffs. Id. at 4274-75.

263 See p. I 286 supra.

${ }^{264}$ The majority opinion in Vail did recognize the need to decide whether an actual preincarceration hearing was required. 45 U.S.L.W. at 4272 . Yet, after concluding that a mere opportunity to be heard was sufficient, it failed to take the next step and recognize that whether the particular state procedure provided an adequate opportunity itself required resolution of the notice claim.

${ }^{265}$ See, e.g., Hicks v. Miranda, 422 U.S. 332, 350 (1975); Younger v. Harris, 40 I U.S. 37,54 (197I).

${ }^{266}$ See Allee v. Medrano, 4I6 U.S. 802, 812-15 (1974) (authorizing injunction against police misconduct irrespective of possible pendency of criminal proceedings against plaintiffs); Hague v. CIO, 307 U.S. 496 (I939) (same).

${ }^{\mathbf{2 6 7}}$ More troubling would be a request for future relief against harassing prosecutions brought by state officials who seek merely to burden the federal plaintiff's arguably protected conduct. Were it certain that the prosecutor was bent on harassment and would continue to file new charges regardless of any judicial determination that the underlying statute was invalid, an acquittal in the pending trial would fail to provide an adequate remedy because it would, by hypothesis, fail to prevent future harassing prosecutions. But such certainty is unlikely before the fact. And in its absence the presumption is that an acquittal on constitutional grounds will provide an adequate remedy. Further, federal adjudication of a harassment claim would ordinarily include a decision on the constitutionality of the underlying statute because only if that statute is defective may the prosecutor properly be restrained from continuing to file charges. Accordingly, in contrast to the situation in the examples in text, the plaintiff's claim in the prosecutorial harassment case turns on the same issue that would be central to the pending state proceeding. His argument is that he should be able to pursue his 
It must be conceded that the foregoing effort to discriminate among categories of claims has not always been followed. ${ }^{268}$ Indeed, the Supreme Court has sometimes tended to dismiss under Younger without distinguishing collateral issues or inquiring scrupulously into the adequacy of the plaintiff's state court remedy. ${ }^{269}$ In its least drastic form, this tendency undercuts Steffel and approaches a requirement that plaintiffs exhaust even those state remedies that require the initiation of litigation. More broadly it is a tendency that can distort the Younger doctrine by viewing it as an open-ended prescription of federal court action that would have a substantial impact on state judiciaries. The result may be to leave plaintiffs without remedies, as well as to obscure the special concerns which support the Younger rule.

\section{F. Exceptions}

Even if the coverage rules developed in the previous Sections were scrupulously applied, the Younger rule would have constitutional costs because it reflects a categorical balance that is inevitably overinclusive. But Younger is not a flat ban on federal interference even where all coverage requirements are met. It permits plaintiffs to escape dismissal by making an extraordinary showing and thereby seeks to mitigate the more egregious instances of overinclusiveness without sacrificing the economy ${ }^{270}$ of the general rule against interference. This Section will consider five circumstances under which the Younger burden may be overcome.

federal suit notwithstanding this identity of issues and the presence of a normally adequate remedy because special circumstances have created a situation in which an acquittal is in fact not substantially equivalent to the injunction he seeks. This is an argument different in kind from that used to avoid Younger in Gerstein or Fuentes. The plaintiff does not assert that a Younger showing is unnecessary but instead tries to make out such a showing by introducing whatever individualized proofs he can muster. He is arguing for an exception to the preclusion requirement.

${ }^{268}$ Compare Pugh v. Rainwater, 483 F.2d 778 (5th Cir. 1973), aff'd in part and rev'd in part sub nom. Gerstein v. Pugh, 420 U.S. I03 (1975); Conover v. Montemuro, 477 F.2d 1073 (3d Cir. 1973); and Lewis v. Kugler, 446 F.2d r343 (3d Cir. 197I) (all generally following the analysis suggested in text), with Wallace v. Kern, 520 F.2d 400 (2d Cir. 1975), cert. denied, 424 U.S. 912 (1976); Rivera v. Freeman, 469 F.2d Ir59 (gth Cir. 1972); Kinney v. Lenon, 447 F.2d 596 (gth Cir. 1971); and Harrington v. Arceneaux, 367 F. Supp. 1268 (W.D. La. 1973) (all suggesting somewhat broader application of Younger). See also New Jersey v. Chesimard, No. 77-r ro4 (3d Cir. March 9, 1977) (en banc).

${ }^{269}$ See Rizzo v. Goode, 423 U.S. 362, 380 (I976); O'Shea v. Littleton, 4I4 U.S. 488,500 (1974).

${ }^{270}$ In addition to conserving judicial resources, the per se quality of the Younger rule often permits courts to avoid potentially intrusive and embarrassing inquiries into the adequacy of the state forum. 
I. Harassment. - The Court has frequently reiterated that federal declaratory and injunctive relief is appropriate where the plaintiff can make out a showing of bad faith or harassment. ${ }^{271}$ Such an exception responds in part to situations in which the prior acts or statements of the prosecutor will support an inference that he will continue to file charges and take other action against the plaintiff even if the underlying statute is declared unconstitutional in the course of a defense to criminal charges. ${ }^{272}$ Making such a showing, and thereby overriding the presumptive adequacy of the declaration of rights available in the course of the criminal trial, may be quite difficult. Apparently the plaintiff will have to show a prior pattern of harassing activities taken without justifiable reliance on state court orders or decisions. ${ }^{273}$

2. Normative Federal Interests. - The references to bad faith and harassment have a second component that suggests grounds for a quite different type of Younger exception - one that also is implicated by the language permitting federal interference with prosecutions brought under statutes so egregious as to be "patently unconstitutional." ${ }^{274}$ Beyond the dangers of future harassment, this language appears to respond to two sorts of broad federal interests. First, it reflects a normative judgment that being prosecuted under certain statutes, or by a prosecutor who has no reasonable expectation of securing a valid conviction, itself goes beyond the burden of defending against charges "brought lawfully and in good faith" ${ }^{275}$ from which no citizen is immune. And second, it may respond to the judgment that the federal interest in swiftly striking down such statutes and censuring such prosecutors outweighs the generally persuasive array of Younger concerns. It is quite clear that "mere" facial overbreadth will not be sufficient to support an exception. ${ }^{276}$ How much more is required remains unclear. The bad faith, patently

${ }^{271}$ See, e.g., Younger v. Harris, 401 U.S. 37,54 (1971).

${ }^{272} \mathrm{See}$ Dombrowski v. Pfister, 380 U.S. 479, 482 (1965); note 267 supra.

${ }^{273}$ See Hicks v. Miranda, 422 U.S. 332, 35I (1975) ("each step in the pattern of seizures condemned by the District Court was authorized by judicial warrant or order"). Compare Krahm v. Graham, 46I F.2d 703, 707 (9th Cir. 1972) (100 charges filed, II acquittals, no convictions), and Potwora v. Dillon, 386 F.2d 74 (2d Cir. 1967) (multiple illegal seizures), with Grandco Corp. v. Rochford, 536 F.2d 197, 203-04 (7th Cir. 1976) (no bad faith where multiple prosecutions are generally successful), and Sandquist v. Pitchess, 332 F. Supp. I7I (C.D. Cal. I97I) (mere multiplicity of prosecutions insufficient to establish bad faith). See also Timmerman v. Brown, 528 F.2d 8I I (4th Cir. 1975) (finding likely bad faith).

${ }^{274}$ Younger v. Harris, $40 \mathrm{I}$ U.S. 37, 53-54 (I97I) (quoting Watson v. Buck, 3 I3 U.S. 387,402 (I 94 I )).

${ }^{275}$ Younger v. Harris, 401 U.S. 37, 47 (1971) (quoting Douglas v. City of Jeannette, 3 I9 U.S. 157, 164 (I943)).

${ }^{278}$ Younger v. Harris, 40 I U.S. 37,53 (I97I). 
unconstitutional exception without question provides authority for courts to inquire into this "how much more" question and into the validity for the particular plaintiff of the categorical observation that defending criminal prosecutions is merely a burden of citizenship.

3. Futility. - It may sometimes be appropriate to scrutinize the actual availability in state court of the putatively adequate remedy to which a Younger dismissal would remit the federal plaintiff. The issue here is the extent to which a state's prior decisional law should be considered by the federal court and permitted to support a finding that federal relief is appropriate because it would be futile to send the plaintiff to state court. A futility exception may be cast into either a substantive or a procedural mold. The former would be triggered whenever prior decisions suggest that the state courts will reject the substance of the plaintiff's constitutional claim. ${ }^{277}$ But, even if rarely utilized in fact, such an exception would be frequently invoked by hopeful plaintiffs. Each prayer would have to be rejected or accepted. And the specter of a flood of such requests for federal district court scrutiny of state court decisions is unsettling. It would reflect poorly on state courts, ignore the possibility that they can change their minds, and undermine the Younger rule by requiring that federal courts look at the merits in any case in which the state's prior decisional law is contrary to the plaintiff's desire.

While such a broad substantive futility exception would therefore seem undesirable, there are narrower sorts of circumstances - usually concerning the adequacy of state procedures and the burdens that they impose - in which a state's prior decisions and practice would be probative of the need for a Younger exception. If the state supreme court recently has held squarely against the plaintiff's substantive claims, lower state courts may be unlikely to come out differently. Accordingly, the plaintiff will in effect have little chance of prevailing on the merits short of either the highest state court (which might change its mind) or the Supreme Court. Where the plaintiff's claim goes to

${ }^{277}$ The Supreme Court has rejected such a broad futility exception. See Hicks v. Miranda, 422 U.S. 332,350 n.18 (1975) (rejecting futility claim because state courts can change their minds, state remedies are adequate, and-curiously adverse state decision came from intermediate court rather than state supreme court); Huffman v. Pursue, Ltd., 420 U.S. 592, 610 (1975) ("no truncation of the exhaustion requirement merely because the losing party in the state court . . . believes his chances ... are not auspicious").

${ }^{278}$ See Cleaver v. Wilcox, 499 F.2d 940, 943-44 (9th Cir. 1974) (state courts repeatedly rejected right to counsel claims asserted in federal suit); Anderson v. Nemetz, 474 F.2d 814, 818 (9th Cir. 1973) (plaintiff had raised constitutional objections four times in state court without success). 
the burden of being prosecuted or the nature of the proceedings to which he is being subjected, the fact of the state's prior decision would appear relevant. ${ }^{278}$ For example, if plaintiff raises a double jeopardy claim in a state the highest court of which has rejected his legal theory, a federal court dismissal will force him through a trial and ensuing appeals prior to having a genuine chance to litigate his objection. ${ }^{279}$ Yet it is precisely that procedural burden that the double jeopardy clause seeks to avoid. ${ }^{280}$ Hence, the prior state decisions require an exception to Younger for such a complaint. ${ }^{281}$ More generally, in determining whether a plaintiff's claim can be raised and remedied in the normal course of state procedures - and therefore whether it can be properly relegated to state court under Younger - it may be necessary to examine how the state procedures actually operate, what sorts of claims can be raised within them, how frequently and under what circumstances extraordinary writs or interlocutory appeals are available, and how burdensome the procedures are. ${ }^{282}$ Where a plaintiff can show that the state's prior practice does not provide an opportunity for him to litigate his claim - even though procedures of the type to which he is being subjected generally do provide such an opportunity - an exception to the Younger requirement would seem appropriate. ${ }^{283}$

4. Bias. - The logic of Younger may, in unusual circumstances, justify an inquiry into the state forum's adequacy. In Gibson v. Berryhill, ${ }^{284}$ the Court suggested that structural in-

${ }^{279}$ See Jackson v. Justices of the Superior Court, 549. F.2d 215 (Ist Cir. 1976) (finding futility exception because of highest state court's rejection of plaintiff's double jeopardy theory).

${ }^{280}$ See United States ex rel. Webb v. Court of Common Pleas, 5I6 F.2d ro34, I037 (3d Cir. 1975) ("one of the principal purposes of the double jeopardy clause is to spare the accused the rigors incident to the subsequent trial") (citing United States v. Lansdown, 460 F.2d I64, I7I (4th Cir. I972)).

${ }^{281}$ Anticipatory habeas corpus actions like the one in United States ex rel. Webb v. Court of Common Pleas, 5 I6 F.2d ro34 (3d Cir. 1975), may provide a favored route for asserting double jeopardy claims. Indeed, such a course might be required. Cf. Preiser v. Rodriguez, 4II U.S. 475 (I973) (requiring prisoners challenging fact or duration of confinement to petition for habeas corpus after exhausting state remedies rather than suing under $\S 1983)$.

${ }^{282} \mathrm{Cf}$. Gerstein v. Pugh, 420 U.S. 103, 105-06 (1975) (scrutinizing state statutory scheme and practice under that scheme in portion of opinion preceding consideration of Younger).

${ }^{283}$ See G.I. Distributors, Inc. v. Murphy, 336 F. Supp. 1036 (S.D.N.Y.) (finding irreparable harm and ordering return of seized materials where state's highest court had ruled against plaintiff's first amendment claim and seeking return of materials in state court would therefore be futile), rev'd on other grounds, 469 F.2d $75^{2}$ (2d Cir. 1972), vacated, 413 U.S. 913 (1973). Declining to award relief would have forced the plaintiff to do without the seized books at least through lower state court proceedings.

${ }^{284} 4$ II U.S. 564 (1973). 
firmities in the state system can, if sufficiently widespread, mandate an exception. The plaintiff there challenged a pending license revocation proceeding before a state board composed entirely of self-employed optometrists with a direct pecuniary interest in keeping salaried optometrists like the plaintiff out of business. ${ }^{285}$ Although the Court had not (and has not) held that Younger applies to administrative proceedings, ${ }^{286}$ it reasoned that "the predicate for a Younger v. Harris dismissal was lacking, for the appellees alleged, and the District Court concluded, that the State Board of Optometry was incompetent by reason of bias to adjudicate the issues pending before it." ${ }^{287}$ In addition, the Court explicitly noted that the availability in state court of judicial review in a de novo proceeding did not compel a different result. ${ }^{288}$

The contours of any inadequate forum exception to Younger are far from clear. While the Gibson Court observed that a Younger dismissal "presupposes ... a competent state tribunal," ${ }^{289}$ the opinion considered a case in which the tribunal's incompetence was unusually clear. The Court's subsequent decision in Kugler v. Helfant ${ }^{290}$ declined to make an exception to the Younger rule where there was an allegation of judicial bias ${ }^{291}$ - thus suggesting a restrictive view of the inadequate forum exception. The plaintiff in Helfant was a New Jersey judge who had been indicted for obstruction of justice. ${ }^{292}$ He argued that he could not receive a fair trial in the state court system because the justices of the New Jersey Supreme Court had coerced him into giving grand jury testimony against himself. ${ }^{293}$ The Court denied all relief after an inquiry into state procedures for disqualifying judges and substituting justices on the highest state court. ${ }^{294}$ The decision showed considerable confidence in the self-corrective capacity of the state court system, but it did not rule out the possibility of a Younger exception predicated on state court bias where state corrective mechanisms are less inclusive. ${ }^{295}$

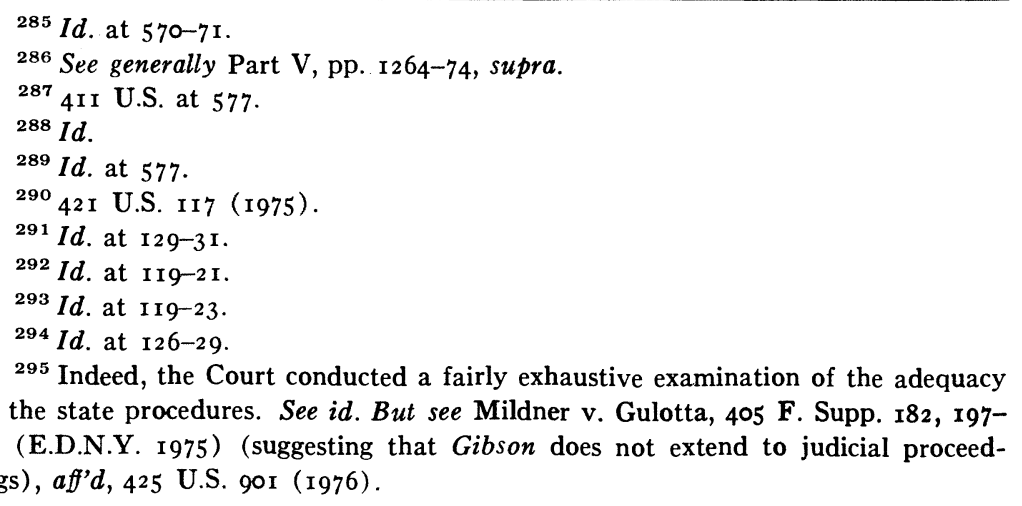


5. Residual Balancing. - Finally, it would seem appropriate to recognize a somewhat amorphous exception to Younger that draws on the language in the cases recalling the balancing tests of equity jurisprudence. Procedural burdens may be substantial while not rising to constitutional proportions and Younger concerns may be implicated to greater or lesser extents. Accordingly, courts need some leeway to conclude in a particular case that the adverse consequences of limited federal relief would be relatively minor and the harms caused by its denial substantial. For example, a declaratory judgment on an issue that in state court could not be determined until the close of protracted litigation may seem appropriate to, and even be welcomed by, all sides. Younger merely strikes a categorical balance. Exceptions are appropriate where that balance is clearly inaccurate.

\section{G. Conclusion}

The Younger doctrine began as a series of judge-made rules for channeling litigation of constitutional claims into the proper forums, avoiding unnecessary and unseemly frictions between state and federal courts, and reducing unnecessary interference with state enforcement of substantive policies. As such, it responds to general forum allocation preferences which may safely be indulged in a society in which at least some of the original congressional suspicion of state prosecutorial and judicial systems is no longer justifiable. But such indulgence is proper under the logic of Younger only where the preferences are directly implicated and there exist sound reasons for assuming that plaintiffs will have adequate state remedies. Justice Black observed in Younger:

"Our Federalism" ... does not mean blind deference to "States' Rights" any more than it means centralization of control over every important issue in our National Government and its courts. . . . [T] he concept does represent . . . a system in which there is sensitivity to the legitimate interests of both State and National Governments. ${ }^{296}$

Younger attempts to realize that sensitivity for relatively specific categories of federal claims filed in relatively specific situations. The strength of its presumption against interference depends for its vitality on the care used in deciding its applicability. Accordingly, it cannot be overemphasized that to extend uncritically the proscriptive requirement of the Younger doctrine is to distort its rationale and render impossible the kind of sensitivity to which Justice Black referred. Two recent Supreme

${ }^{296}$ Younger v. Harris, 40 I U.S. 37,44 (I97I). 
Court decisions evince an unfortunate tendency so to extend Younger.

The first was O'Shea $v$. Littleton. ${ }^{297}$ After holding that the allegations of discriminatory bond setting, jury fee practices, and sentencing did not present a case or controvery, ${ }^{298}$ Justice White's opinion moved on to the merits and concluded ${ }^{299}$ that a showing of irreparable injury "both great and immediate" is required to support the issuance of injunctions against state officers engaged in the administration of the state's criminal laws. ${ }^{300}$ Accordingly, he asserted that the principles of equitable restraint enunciated in Younger "preclude equitable intervention in the circumstances present here." 301 Federal relief, he wrote, would amount to "nothing less than an ongoing audit of state criminal proceedings which would indirectly accomplish the kind of interference that Younger v. Harris . . . sought to prevent." ${ }^{302}$

The Court's error is that Younger did not seek simply to prevent interference with state officers and intrusion into state courts. It sought to identify and prevent undue or unnecessary interference. ${ }^{303}$ The mere fact that the sought-after relief would have an impact - perhaps a sizable one - on a state's criminal justice system is not alone grounds for dismissal for the simple reason that Younger is predicated upon the existence of an adequate state remedy. Yet, notwithstanding Justice White's efforts to the contrary, there are many reasons to doubt the adequacy of the state remedies, and hence the appropriateness of Younger analysis, in O'Shea. The Court asserted that procedures for disqualification of judges, change of venue, appeal, collateral attack, and disciplinary or criminal actions against the state judges would provide the plaintiffs with an adequate remedy. ${ }^{304}$ In fact, these individualistic and extraordinary remedies would seem irrelevant to the bond setting and jury fee allegations and poorly suited to a general claim of systemic discrimination in sentencing. Such a general claim raises substantial questions about both the competence of the state court system to hear the allegations and the constitutionality - or at least the fairness of requiring members of the disfavored class to remain within that system. Further, even absent such concerns, individual

${ }^{297} 414$ U.S. 488 (1974).

298 Id. at 493.

${ }^{299}$ See id. at 504-05 (Blackmun, J., concurring in part) (objecting to portion of opinion reaching the merits).

${ }^{300}$ Id. at 499 .

$301 \mathrm{Id}$.

302 Id. at 400.

303 Younger v. Harris, 40I U.S. 37, 44 (1971).

${ }^{304} 414$ U.S. at $502-03$. 
criminal proceedings and postconviction remedies are unlikely to provide an adequate opportunity for the defendant to litigate a challenge based upon a pattern or practice of discriminatory sentences and thus secure modification of his own sentence. The substance of the alleged violation would go not to the egregiousness of his sentence standing alone, but to its relationship to prior sentences meted out against others. In light of the substantial discretion generally accorded to the sentencing judge, it may be exceedingly difficult to overturn or reduce a facially reasonable sentence in the course of criminal appeals. ${ }^{305}$

Finally, it should be observed that the undoubtedly perplexing problems of shaping relief once a violation has been found in a case like O'Shea are and should be separate from the Younger calculus. $^{306}$ The nature of the proper relief will of course depend upon the violation, the dangers of overinclusiveness and unnecessary intrusiveness, administrability, and other factors. Federalism may play a role in tailoring the relief. But it is a role to which the Younger doctrine is an outsider, notwithstanding the presence of some common underlying values. Using Younger to hold that relief is impermissible and the claim therefore not cognizable is tantamount to a decision on the merits, or a decision that the whole area is somehow beyond the jurisdiction of the federal courts. That such a sweeping result may be reached without analysis of the underlying constitutional claim is an unfortunate testimonial to the dangers of misusing Younger.

An even more eloquent testimonial is provided by the Supreme Court's decision in Rizzo v. Goode. ${ }^{307}$ In an opinion by Justice Rehnquist, the Court overturned an injunction requiring the Philadelphia police department to adopt certain procedures designed to reduce police abuses. ${ }^{308}$ The decision appears to rest upon a number of alternative theories, including one sounding in justiciability, ${ }^{309}$ before reaching what Justice Rehnquist seems to have seen as a Younger problem. ${ }^{310}$ After citing O'Shea, Doran, Huffman, and the rhetoric of "equity, comity and federalism," Justice Rehnquist asserted:

${ }^{305}$ See id. at 5 I0-I I (Douglas, J., dissenting).

${ }^{306}$ This is especially the case in a situation like that in O'Shea when the state criminal justice system is under attack. If relief is justified because the state system is violating the Constitution, it would be improper to defer to that system in the process of shaping relief. Once a violation is found, the Younger concerns are markedly reduced.

${ }^{307} 423$ U.S. 362 (1976).

${ }^{308} I d$. at 366,370 .

${ }^{309} \mathrm{Id}$. at $37 \mathrm{I}-73$.

${ }^{310} I d$. at $379-80$. The multiplicity of theories relied upon by the Court makes the precise weight given to any one of them difficult to determine. 
[T]he principles of federalism which play such an important part in governing the relationship between federal courts and state governments, though initially expounded and perhaps entitled to their greatest weight in cases where it was sought to enjoin a criminal prosecution in progress, have not been limited either to that situation or indeed to a criminal proceeding itself. We think these principles likewise have applicability where injunctive relief is sought ... against those in charge of an executive branch of an agency of state or local governments .... . $^{311}$

Precisely what Justice Rehnquist meant is less than clear. It cannot be disputed that some concern for federalism may play a role in shaping injunctive relief against state officials. But the quoted language seems to refer more narrowly to the Younger doctrine - to suggest that the rules compelling restraint in enjoining criminal proceedings "likewise" compel deference to executive action. Such a view misconstrues Younger, fails to examine the harms facing the plaintiff or adequacy of other remedies, and collapses Younger into a decision on the merits. In doing so, it may keep the court from making a needed inquiry into the substance of the constitutional claim.

Looked at broadly, the problem originates in the aforementioned fact that every Younger dismissal has a quasi-substantive component - the decision that being subjected to a pending proceeding is not itself a constitutional deprivation. Even in relatively traditional Younger cases, it is necessary to beware of the danger that dismissal will involve a constitutional decision that should be considered and decided on its own terms. Where there is no state proceeding, as in the kinds of cases which Justice Rehnquist's dicta suggest may now be subjects for Younger dismissal, the included substantive decision may be extremely open-ended. The result can be to shape constitutional rights under the auspices of a doctrine which purports not to concern itself with substantive rights.

\section{The Preclusive Effect of Prior State and Federal Judgments}

The issue of preclusive effect arises in two contexts relevant to section r 983 . First, questions of law and fact pertinent to section r 983 suits are frequently the subject of criminal and civil litigation in the state courts, at times because of the mandates of the Younger doctrine. Whether and when federal courts may reexamine such conclusions of law and fact, or indeed the judgment

${ }^{311}$ Id. at 380 . 
reached in the state proceeding itself, depend upon the preclusive effect which attaches to the prior state determinations. Second, there is the question of what preclusive effect attaches to federal declaratory judgments given in section 1983 suits - that is, to what extent such judgments bar the state from subsequently prosecuting either the federal plaintiff or any other individual under a statute declared unconstitutional in the federal proceeding. To date, the Supreme Court has avoided any explicit decisions of these issues, ${ }^{1}$ and the lower courts have reached conflicting results. $^{2}$ The first part of this section will address the question of federal relitigation of claims or issues decided in state court; the second, the effect of federal declaratory judgments on subsequent state proceedings.

\section{A. The Res Judicata Effect of Prior State Court Judgments on Subsequent Section I983 Actions}

Two related doctrines subsumed under the rubric of res judicata generally make the final judgment of a court of competent jurisdiction conclusive on the parties. ${ }^{3}$ First, claim preclusion, also known as merger and bar, ${ }^{4}$ prevents a plaintiff from bringing a second suit on the same claim, "although of course he may bring

${ }^{1}$ See Ellis v. Dyson, 42 I U.S. 426, 440 (1975) (Powell, J., dissenting) ; Preiser v. Rodriguez, 4II U.S. 475, 497, 509 n.I4 (I973). Occasionally, individual Justices have noticed the urgency of settling the question. See Florida State Bd. of Dentistry v. Mack, 40I U.S. 960, 960 (I97I) (White, J., \& Burger, C.J., dissenting from denial of certiorari). The Court may have impliedly foreclosed at least collateral impeachment of final state court judgments in Huffman v. Pursue, Ltd., 420 U.S. 593 (1975). See p. 1337 and n.32 infra.

${ }^{2}$ Although most federal courts have concluded that normal principles of res judicata apply to suits brought under $\S 1983$, see notes 27 and 37 infra, some courts and individual judges have suggested that the ordinary principles of preclusion might be inappropriate in such suits, see, e.g., Lombard v. Board of Educ., 562 F.2d 631 (2d Cir. 1974); Thistlethwaite v. City of New York, 497 F.2d 339, 343-46 (2d Cir. 1974) (Oakes, J., dissenting), cert. denied, 4I9 U.S. 1093 (I974); Brown v. Chastain, 4I6 F.2d I012, 102 I (5th Cir. 1969) (Rives, J., dissenting); Whitner v. Davis, 410 F.2d 24 (9th Cir. I969) (dictum); Mack v. Florida State Bd. of Dentistry, 430 F.2d 862 (5th Cir. 1970) (by implication), cert. denied, $40 \mathrm{I}$ U.S. 960 (197I).

${ }^{3}$ See generally Developments in the Law-Res Judicata, 65 HARv. L. Rev. 818 (1952) [hereinafter cited as Res Judicata]; F. James, CiviL Procedure §§ ir.9-35 (1965); ib J. Moore, Federal Practice IT 0.405-.448 (2d ed. i974); ReStatement (Second) of Judgments ch. 3 (Tent. Draft No. I, i973).

${ }^{4}$ The plaintiff's claim is said to be "merged" in the judgment if he wins, REStatement (SECond) of Judgments, supra note $3, \S 47$ (a), or "barred" by it if he loses, id. § 48 .

${ }^{5}$ There is variation among jurisdictions with regard to the scope of a "claim" or "cause of action" for purposes of preclusion. See id. § 6I, Reporter's Note at 90-94; Res Judicata, supra note 3, at 824-31. The Second Restatement adopts the increasingly prevalent "transactional" view of what "should have been con- 
an action on the judgment $;^{6}$ and a defendant is estopped from impeaching an adverse judgment, except in those limited cases where state or federal law affords equitable relief from a judgment ${ }^{7}$ or where federal habeas corpus is available. ${ }^{8}$ Second, the

sidered," defining the claim to include all of the plaintiff's remedial rights against the defendant growing out of the pertinent transaction. Restatement (SECOND) of Judgments, supra note $3, \S 6 \mathrm{I}$, Comment at 78-94; Res Judicata, supra note 3 , at 824 .

${ }^{6}$ See Restatement (Second) of Judgments, supra note $3, \S 45$, Comment a, at $2 \mathrm{I} ;$ id. at $\$ 47(\mathrm{a})$.

${ }^{7}$ A defendant who has lost in the prior suit is precluded from defending a suit brought on the judgment by raising any defenses that he raised or might have raised in the prior proceeding. See id. \$ 47 (b), Comment c, at 27-28.

A person otherwise bound or having some legal interest adversely affected by a state judgment may seek to avoid the judgment's res judicata effects either by obtaining relief setting aside the judgment or by relying on some rule limiting the effect of an admittedly valid judgment. Equitable relief from a judgment ordinarily may be given if such relief would have been available in the courts of the state that rendered the judgment. See Restatement (Second) of Conflict of LAws § II5, Comment a (I969); 7 J. MOoRe, supra note 3, If 60.37[3]. Of course, a state judgment may also be avoided on various federal constitutional grounds. See, e.g., Hanson v. Denckla, 357 U.S. 235, 250 (1958) ; Restatement of JudGments $\$ \S 5-8$ (I942); Restatement (Second) of Conflict of Laws 92 (ig69). An independent federal suit seeking equitable relief must have a statutory jurisdictional base, which will depend on the grounds alleged to set aside the judgment. See 7 J. Moore, supra note 3, If 60.39[I] at 654. Even where the state law provides the rule of decision as to the permissibility of relief, see 7 id. $\| 60.37$ [3], at 640-4I; Restatement (Second) of Conflicts of Laws ii5, Comment b (ig69), the procedures and propriety of granting it are federal questions, id. Thus, for example, if a post-judgment motion for relief, e.g., FED. R. CIV. P. 60(b); CAL. Civ. Proc. Code $\$ \S 473-474$, could still be brought in the court that rendered the judgment, the federal court in its discretion might remit the parties to that proceeding. Although there are some decisions, see e.g., Atlantic Coast Line R.R. v. Brotherhood of Locomotive Eng'rs, 398 U.S. 28I (1970), which suggest that federal injunctions against the enforcement of state judgments are barred by the AntiInjunction Act, 28 U.S.C. $\$ 2283$ ( 1970 ), the question is far from settled, see P. Bator, P. Mishikin, D. Shapiro \& H. Wechsler, Hart and Wechsler's The Federal Courts and the Federal System 1236, r253 (2d ed. 1973) [hereinafter cited as Hart \& WechsLER]. It would seem that because relief from judgment is a normal exercise of equity jurisdiction, if a federal court had jurisdiction over an action for relief, then the injunction would not be barred by $\S 2283$, though of course the federal court might decline if relief were available in the first court, see J. Moore, supra note 3, $\llbracket 60.39[2]$. Similarly the Younger doctrine should not be thought to foreclose independently such federal relief, though concerns of comity will be relevant to both contexts. But see Duke v. Texas, 477 F.2d 244 (5th Cir. r973); Lynch v. Snepp, 472 F.2d 769 (4th Cir. 1973).

The cases treated in this Part do not involve relief from state judgments in the orthodox sense. Rather they concern attempts to avoid the res judicata effects of presumedly valid judgments. Of course, such qualifications of res judicata are often practically indistinguishable from other forms of relief; both frequently depend on such things as adequacy of hearing. But typically the cases discussed below seek, often impliedly, to avoid preclusion simply on grounds of error in the state proceeding raising a federal question or on grounds that the federal claim 
doctrine of collateral estoppel, or "issue" preclusion, makes conclusive on the parties issues of fact or law actually litigated and necessary to the prior judgment, even if the second suit is based on a different cause of action. ${ }^{9}$

Foreclosure of relitigation under the doctrine of res judiciata serves several important interests: the efficient use of judicial resources, preservation of the integrity of prior judgments and facilitation of the parties' reliance thereon, fostering respect for the rendering court, and avoidance of inconvenience and harassment of the litigants. ${ }^{10}$ In the context of section 1983 suits subsequent to state court adjudication, the avoidance of federal-state friction is implicated as well. To foreclose all subsequent relitigation in the federal courts, however, would substantially undermine the basic premise of forum choice which underlies the grant of jurisdiction to the federal courts to decide section 1983 actions. ${ }^{11}$ Thus, several courts and commentators have urged that the rules foreclosing relitigation should be considered inapplicable to section 1983 actions. ${ }^{12}$

An initial difficulty with any exception to traditional rules of preclusion in section 1983 actions is that a federal statute, imple-

was not raised at all. While federal habeas corpus permits relief from some judgments on grounds of error, see Brown v. Allen, 344 U.S. 443 (r953), it is well settled that apart from habeas relief, judgments may not be impeached merely upon a showing of error. See Restatement (Second) of Judgments, supra note 3 , $\S 45$, Comment d, Reporter's Note at 23-24. The question discussed in text then is whether, as a matter of federal law, allegations of state court error permit federal courts to relitigate the merits underlying state court judgments upon a theory either that such error invalidates the judgment or, as is more commonly argued, that federal questions and related facts pertinent to $\S$ I 983 suits are immune from the effects of full faith and credit. It is in this sense of avoiding the orthodox binding effects of a state judgment that this Part uses the word "impeach."

${ }^{8}$ See 28 U.S.C. \$§ 224 I-2255 (I970).

9 Restatement (Second) of Judgments, supra note $3, \S 68$.

${ }^{10}$ See Res Judicata, supra note 3, at 824-28.

${ }^{11}$ A suspension of all res judicata effect of prior state judgments in suits brought under $\S 1983$ is predicated on an unqualified "right to a federal forum" for the trial of federal claims, arguably inferred from an expansive reading of Monroe v. Pape, 365 U.S. I67 (I96I). However, the proposition that state court judgments resting on federal questions decided adversely to the $\S$ I 983 plaintiff are to be denied finality is not an obvious corollary to the theory that $\$$ I 983 afford a remedy "supplementary to the state remedy," id. at 183. Monroe only declared that $\S 1983$ provided a federal cause of action regardless of the availability of state tort remedies. It would be a substantial gloss to suppose that state courts were thereby divested of their usual competence to render final judgments.

${ }^{12}$ See, e.g., cases cited note 2 supra; Averitt, Federal Section 1983 Actions After State Court Judgments, 44 U. CoLo. L. Rev. I91, 195-96 (1972) ; McCormack, Federalism and Section 1983: Limitations on Judicial Enforcement of Constitutional Claims (pt. 2), 60 VA. L. REv. 250, 276-77 (1974); Theis, Res Judicata in Civil Rights Act Cases: An Introduction to the Problem, 70 Nw. U.L. Rev. 859, 868 (1976). 
menting the full faith and credit clause of the Constitution, requires federal courts to give a prior state judgment the same conclusive effects as would the courts of that state. ${ }^{13}$ While federal courts frequently disregard this statutory mandate ${ }^{14}$ and instead seem to decide cases with regard to a general federal law of res judicata, ${ }^{15}$ the statute, 28 U.S.C. $\S 1738,{ }^{16}$ quite clearly provides a rule of decision:

[J] udicial proceedings ... shall have the same full faith and credit in every court within the United States and its Territories and Possessions as they have by law or usage in the courts of such state . . . from which they were taken.

Exceptions to full faith and credit, however, occasionally have been founded on special grants of jurisdiction to the lower federal courts. For example, in Lyons v. Westinghouse Electric Corp., ${ }^{17}$ the Second Circuit considered the collateral estoppel effect of a state court determination of an issue raised defensively in a state law action which, if asserted affirmatively, would fall within the exclusive federal jurisdiction over antitrust claims. ${ }^{18}$ Recognizing the state court's jurisdiction to pass on the antitrust defense, ${ }^{19}$ Judge Learned Hand nonetheless held that the federal courts' exclusive jurisdiction over treble damage actions "should be

${ }^{13}$ The statutory mandate applies to "every court within the United States," 28 U.S.C. § I738 (1970), although the full faith and credit clause of the Constitution, U.S. Const. art. IV, § I, by its terms speaks only of the effects of state court judgments in other states' courts.

${ }^{14}$ See, e.g., Bricker v. Crane, 468 F.2d I 228 (Ist Cir. 1972), cert. denied, 4 Io U.S. 930 ( 1973 ). There is a line of cases holding that the inability of federal courts to rehear claims already litigated in state proceedings is jurisdictional. See, e.g., Tang v. Appellate Div., 487 F.2d 138, I4I (2d Cir. I973), cert. denied, 4 I6 U.S. 906 (1974); Brown v. Chastain, 4I6 F.2d ror2, ror3 (5th Cir. 1969), cert. denied, 397 U.S. 95 I (1970). Such cases usually rely on Rooker v. Fidelity Trust Co., 263 U.S. 4 I3 ( 1923 ), which held that a district court lacked jurisdiction to hear a petition to declare a state judgment "null and void." Such a jurisdictional dismissal would be inappropriate unless it appeared on the face of the complaint that the plaintiff was seeking appellate review of the state court judgment. See Tang v. Appellate Div., 487 F.2d at $145-46$ (Oakes, J. dissenting). Absent such a facial defect in the pleading, which could easily be remedied under the permissive rules for amending complaints, FED. R. CIv. P. 15, the federal court would have jurisdiction, see Bell v. Hood, 327 U.S. 678 (1946), although the suit still would be susceptible to dismissal on the merits under the doctrine of res judicata.

${ }^{15}$ See, e.g., Mastracchio v. Ricci, 498 F.2d I257, I260 (Ist Cir. I974); P. Bator, P. Mishkin, D. Shapiro \& H. Wechsler, Hart \& Wechsler's The Federal Courts and the Federal System I5I (2d ed. Supp. 1977).

${ }^{16}{ }_{28}$ U.S.C. \& I 738 (1970).

${ }^{17} 222$ F.2d 184 (2d Cir.), cert. denied, 350 U.S. 825 (1955).

18222 F.2d at 185 .

${ }^{19}$ Id. at 187 . 
taken to imply an immunity of their decisions from any prejudgment elsewhere." 20

While federal jurisdiction over section 1983 claims is not exclusive, ${ }^{21}$ the establishment of a right of action with an accompanying grant of federal jurisdiction might be understood to imply an exception to section 1738 as an expression of congressional intent that the federal courts be available to redress misconduct by state officials. ${ }^{22}$ Indeed, in Mitchum v. Foster, ${ }^{23}$ the Supreme Court found section 1983 to be an "expressly authorized" exception to the Anti-Injunction Act, ${ }^{24}$ which prohibits federal courts from enjoining state court proceedings. The analogy to the Anti-Injunction Act, however, is not without difficulties. First, the existence of federal equitable power occasionally to enjoin a state proceeding is an intrusion upon state judicial power of a far smaller order than is a denial of finality to state judg-

${ }^{20}$ Id. at 189 . It is questionable whether Judge Hand successfully distinguished Becher v. Contoure Laboratories, 279 U.S. 388 (1929), where the Supreme Court held that a state court judgment that a patent holder held a patent as a constructive trust for another precluded a federal suit for patent infringement within the exclusive federal jurisdiction, 28 U.S.C. § I338 (1970). Judge Hand attempted to distinguish Becher on the ground that there the state judgment was conclusive only as to a single fact, while in Lyons, "the putative estoppel includes the whole nexus of facts that makes up the wrong," 222 F.2d at 189 . The distinction is a difficult one, see IB J. MoORE, supra note 3 , I 0.445 at 4II3-I4. There is the further distinction that the decision in Becher was grounded entirely on state law while in Lyons the state court decided a question of federal antitrust law, see 40 Minn. L. Rev. 618, 620 (1956), but that alone would not explain the denial of estoppel at least as to questions of fact. Although most later decisions have not followed the Lyons result, see, e.g., Azalea Drive-in Theatre, Inc. v. Hanft, 540 F.2d 713 (4th Cir. 1976); Note, Res Judicata: Exclusive Federal Jurisdiction and the Effect of Prior State Court Determinations, 53 VA. L. REv. 1360, 1369 (1967), Judge Hand's analysis leads to a satisfying accommodation of the interests involved, and is supported by the functional approach to collateral estoppel between jurisdictions taken in Restatement (SECoND) of Judgments, supra note 3 , § 68. I, Comment e, Reporter's Note at $186-87$; Res Judicata, supra note 3 , at $848-$ 50; Restatement of Judgments § 7 I (I94I).

${ }^{21}$ See 28 U.S.C. § I343(3) (1970).

22 See pp. II 53-56 supra.

Since it was thought that civil rights litigation would be brought naturally in the federal courts, it was unnecessary to limit the states' otherwise plenary jurisdiction in order to preserve a hospitable forum for adjudicating federal rights.

${ }^{23} 407$ U.S. 225 (1972).

24 The first clause of 28 U.S.C. $\$ 2283$ (1970) codified the judicially recognized exception that allowed an injunction against a state court proceeding when "expressly authorized by Act of Congress," see pp. 1287-88 \& nn. 83, 88 supra. The Court in Mitchum reviewed the legislative history of the Civil Rights Act of I87 I, and observing that Congress had "interposed" the federal courts between the people and abusive state action, 407 U.S. at $238-43$, concluded that enjoining state court proceedings would occasionally be necessary to avert deprivations of fundamental rights, id. at 242 . 
ments. Second, Mitchum itself is not strong precedent for broad federal power, since the Court substantially undercut its statutory holding by reaffirming the rule of Younger $v$. Harris ${ }^{25}$ that principles of federalism, comity, and equity generally preclude federal equitable intrusions into pending state proceedings. ${ }^{26}$

A complete exception for section 1983 claims from section I 738 would permit litigants to impeach adverse state court judgments by raising their federal claims in a subsequent 1983 action and obtaining federal relief nullifying the effects of those judgments. ${ }^{27}$ Such a rule would be costly both in terms of federalstate tensions and judicial economy, for it would deny state courts their usual competence to decide with finality questions that are within their jurisdiction and would hamper the state's ability to enforce its substantive law. Only if one believed that state courts were systematically either unwilling or unable to enforce federal constitutional rights could such costs be justified. To adopt such an argument, however, and to allow state judgments thus to be impeached, is wholly inconsistent with the logic and application of the Younger doctrine. ${ }^{28}$ It would make little sense

${ }^{25} 40$ I U.S. 37 (I 97 I).

${ }^{26} 407$ U.S. at $243-44$; see pp. I275-78 supra.

${ }^{27}$ Federal courts generally have held that a person who has voluntarily brought his claim in state court is barred by an adverse state judgment from bringing a $\S 1983$ suit in federal court on that same claim, see, e.g., Roy v. Jones, 484 F.2d 96, 98 (3d Cir. 1973) ; Lackawanna Police Benevolent Ass'n v. Balen, 446 F.2d 52 (2d Cir. I97I), even where the federal claim was not presented to the state courts, see, e.g., Flynn v. State Bd. of Chiropractic Examiners, 4I 8 F.2d 668 (9th Cir. I969) ; Frazier v. East Baton Rouge Parish School Bd., 363 F.2d 86I (5th Cir. 1966). But see Lombard v. Board of Educ., 502 F.2d 631, 635-37 (2d Cir. 1974), cert. denied, 420 U.S. 976 (I975). Federal courts have been more reluctant to find state judgments res judicata when they have followed state administrative hearings and may have occasioned limited review by the state courts of the agency action. Mack v. Florida State Bd. of Dentistry, 430 F.2d 862 (5th Cir. I970), cert. denied, 40I U.S. 954 (I97I); Whitner v. Davis, 410 F.2d 24, 3 I (9th Cir. I969) (dictum); Jensen v. Olson, 353 F.2d 825 (8th Cir. I965).

Impeachment of a state civil judgment through suits brought under $\$$ I 983 appears to have been implicitly rejected in Huffman v. Pursue, Ltd., 420 U.S. 592 (1975). See generally p. I344 infra. Although the Court has not reached the question in criminal cases outside the scope of federal habeas corpus, see Ellis $\mathrm{v}$. Dyson, 42 I U.S. 426, 440-4I (I975) (Powell, J., dissenting), the consensus in the lower courts is that res judicata precludes collateral impeachment via suits brought under $\$ 1983$ following either criminal cases, see, e.g., Goss v. Illinois, 3I2 F.2d 257 ( 7 th Cir. I963), or civil suits, see, e.g., Lovely v. Liberte, 498 F.2d I 26I (Ist Cir. I974); Coogan v. Cincinnati Bar Ass'n, 43 I F.2d I 209 (6th Cir. I970) ; Kay v. Florida Bar Ass'n, 323 F. Supp. I I49 (S.D. Fla. I97r). Collateral attack is impermissible even if the state court defendant was unable to litigate the federal claim because of an adequate state procedural ground, see, e.g., Mertes v. Mertes, 350 F. Supp. 472 (D. Del. I972).

${ }^{28}$ See Huffman v. Pursue, Ltd., 420 U.S. 592, 61 I (1975) ("Appellee is in truth urging us to base a rule on the assumption that state judges will not be 
to require litigants to resort initially to a state forum if that court's judgments could routinely be reopened in the federal courts from which the individual was initially barred. ${ }^{29}$ Indeed, in Huffman v. Pursue, Ltd. ${ }^{30}$ the Supreme Court, while it did not reach the res judicata question, ${ }^{31}$ implied that section 1983 would not be available to impeach state judgments. ${ }^{32}$

Federal habeas corpus is, of course, one instance where the costs of collateral attack are incurred. But because federal habeas corpus may be invoked only after the exhaustion of available state remedies, ${ }^{34}$ the states retain the opportunity to review and correct their judgments prior to federal intervention. More importantly, federal habeas corpus rests on the paramount importance of freedom from unlawful restraint. ${ }^{35}$ And even in the face of this compelling justification, the Supreme Court has recently restricted the circumstances in which collateral attack on a writ of habeas corpus is available. ${ }^{36}$ Whether or not cutbacks in

faithful to their constitutional responsibilities. This we refuse to do."). But cf. Preiser v. Rodriguez, 4 II U.S. 475, 509 n.I4 (I973) (Brennan, J., dissenting) (applying res judicata in suits brought under $\S$ I 983 would ignore "congressional misgivings about the ability and inclination of state courts to enforce federally protected rights").

${ }^{29}$ Federal statutes and judge-made rules in addition to the Younger doctrine operate to confine claims regarding certain subject matter to state courts. See, e.g., Johnson Act of 1934,28 U.S.C. \& 1342 (1970) (forbidding federal injunctions against state public utility ratemaking if "a plain, speedy and efficient remedy may be had in the courts of such State") ; Tax Injunction Act of 1937,28 U.S.C. § I34I (I970) ; Ferry v. Spokane, P. \& S. Ry., 258 U.S. 314 (I922) (marital relations); Alabama Pub. Serv. Comm'n v. Southern Ry., 34I U.S. 34I (I95 I) (federal suit challenging state agency action dismissed because matter involved "predominantly local factors").

${ }^{30} 420$ U.S. 592 (I 975 ).

${ }^{31}$ The affirmative defense had not been properly pleaded and was not, therefore, before the Court, id. at 607-09; see FED. R. CIv. P. 8(c).

${ }^{32}$ Rejecting the argument that the Younger doctrine forecloses access to a federal forum only where collateral review through federal habeas corpus would later be available, the Court explained that Younger rested on principles of comity, equity, and federalism, not on the possibility of later collateral federal review. 420 U.S. at $605-07$. Moreover, in a footnote the Court added:

We in no way intend to suggest that there is a right of access to a federal forum for the disposition of all federal issues, or that the normal rules of res judicata and judicial estoppel do not operate to bar relitigation in actions under 42 U.S.C. $\$ 1983$ of federal issues arising in state court proceedings.

Id. at 606 n.I8.

3328 U.S.C. \$§ $224 \mathrm{I}-2254$ (1970). See generally Developments in the LawFederal Habeas Corpus, 83 Harv. L. Rev. I038 (1970).

${ }^{34} 28$ U.S.C. \& 2254 (b), (c) (I970).

${ }^{35}$ See Fay v. Noia, 372 U.S. 39I, 400-02 (I963); Ellis v. Dyson, $42 \mathrm{I}$ U.S. 426, 440-4I (I975) (Powell, J., dissenting).

${ }^{36}$ See Stone v. Powell, 428 U.S. 465 (1976) (federal habeas corpus not available to review claim that unlawfully obtained evidence was introduced at state trial if 
the availability of federal habeas corpus are wise, it seems clear that in cases where habeas review is not available, permitting attack on state judgments through actions brought under section I983 cannot be justified in light of the costs involved and the constraints imposed by the continued viability of the Younger doctrine.

These factors do not, however, foreclose a narrower exception to section 1738 , permitting issues of fact and law litigated in state court to be relitigated in a section 1983 action. ${ }^{37}$ While the federal interest in providing plaintiffs with a choice of forums in which to litigate their constitutional claims remains constant in the two contexts, the policies justifying res judicata are not as substan-

state proceeding afforded an opportunity for full and fair hearing of claim); Francis v. Henderson, 425 U.S. 536 (1976) (federal habeas review of state court convictions on grounds of allegedly unconstitutional grand jury composition unavailable absent showings of "cause" for failure to bring a challenge before trial and of actual prejudice).

${ }^{37}$ The doctrine of collateral estoppel by prior state judgment applies to federal cases through 28 U.S.C. $\S \mathrm{I} 738$ (I970), see, e.g., American Mannex Corp. v. Rozands, 462 F.2d 688 (5th Cir.), cert. denied, 409 U.S. I040 (1972); Iв J. MOORE, supra note $3, \mathbb{0} 0.44^{2}$, with the scope of the estoppel to be determined by reference to the law of the state whose court rendered the prior judgment, id. The federal courts have generally held that principles of collateral estoppel operate in $\S 1983$ suits brought following either state civil suits, see, e.g., Parker v. McKeithen, 488 F.2d 553 (5th Cir.), cert. denied, 4I9 U.S. 838 (1974), or criminal actions, see, e.g., Mastracchio v. Ricci, 498 F.2d I257 (Ist Cir. 1974), cert. denied, 420 U.S. 909 (1975); Kauffman v. Moss. 420 F.2d 1270 (3d Cir.), cert. denied, 400 U.S. 846 (1970). Ordinarily the courts are sensitive about whether an issue was actually litigated and necessary to the judgment, see, e.g., id. at I274; Jackson v. Official Representatives, 487 F.2d 885 (9th Cir. 1973). But see Palma v. Powers, 295 F. Supp. 924, 937 (N.D. Ill. I969).

The practical consequences of according prior state judgments collateral estoppel effect in suits brought under $\$ 1983$ will depend on the application of state law through $\S \mathrm{I} 738$ as well as on the informal implications of the adverse state determination. For example, if state law were to require mutuality of estoppel, the state court determination would ordinarily not be available to the $\$$ I 983 defendant. See p. I334 infra. Similarly, were state law to deny estoppel effects when the first proceeding was criminal, and the second one civil, see Res Judicata, supra note 3 , at $878-79$, the state law estoppel would be much less burdensome. Further, if as a matter of federal law the reversal on habeas of a contrary state finding would remove the estoppel based on the state finding, see Moran v. Mitchell, 354 F. Supp. 86, 89 (E.D. Va. I973) (dictum), then even if state law were to allow nonmutual estoppel, successful habeas petitioners might avoid preclusion. Finally, even were there no formal estoppel, as a practical matter it is unlikely an official would be found liable given the various immunities and defenses available to him in $\S 1983$ actions, see pp. I209-17 supra, particularly if the state determination could be introduced for its evidentiary value. See, e.g., FED. R. Evid. 8o3(8). See generally, C. MCCormick, Evidence § 3i8 (2d ed. E. Cleary I972). 
tially implicated by collateral estoppel. ${ }^{38}$ Clearly, the integrity of the prior judgment and the parties' reliance thereon are not jeopardized to the same extent when the federal court is engaged in relitigation of particular issues of law and fact rather than in reexamination and possible nullification of that judgment. The waste of judicial resources is ordinarily less severe, as is the inconvenience to the parties and the affront to the court. Moreover, while claim preclusion in the federal system may be justified by the need to foster certainty and uniformity in the enforcement of state substantive law, giving collateral estoppel effect to state decisions of federal law may undermine the federal interest in the consistent and correct application of federal law to claims brought in the federal courts. ${ }^{39}$ And with respect to questions of fact, the Supreme Court itself has recognized the values which may attach to federal factfinding, regarding them as sufficient to require the federal courts to find facts independently where they have abstained on issues of state law. ${ }^{40}$

The argument in favor of a limited exception to section 1738 for collateral estoppel ${ }^{41}$ is further buttressed by examination of

${ }^{38}$ See generally ReStatement (SECONd) of Judgments, supra note 3, at I4344 .

${ }^{39}$ Since collateral estoppel has been narrowly applied until quite recently, the Reconstruction Congress could not have anticipated the impediment that a more liberal usage would be to $\S \mathrm{I} 983$ suits. This is particularly true with respect to the requirement that an estoppel be "mutual" - a condition that is imposed in either of two forms: (I) that the parties in the second suit were parties or privies to the prior judgment, or (2) that if the determination had been the reverse, the one now raising the estoppel would also have been barred. See iв J. Moore, supra note 3, II 0.418 at 2708 . Though various exceptions were later found to these principles in most jurisdictions, see Res Judicata, supra note 3 , at $862-65$, only recently have the principles been more generally relaxed, see Bernhard v. Bank of America, I 9 Cal. 2d 807, I 22 P.2d 892 (I942); Blonder-Tongue Labs., Inc. v. University of Ill. Foundation, 402 U.S. 313 (I97I) ; A. Freeman, A Treatise on the Law of JUDGMENTS $\$$ I54, I59, 3 I9 ( I973).

${ }^{40}$ See England v. Louisiana State Bd. of Medical Examiners, 375 U.S. 4II, 4I6-I7 (I9.64). See also Neuborne, The Myth of Parity, 90 Harv. L. Rev. I I05, III9\& $\mathrm{n} .53$ ( I977).

${ }^{41}$ Of course, it would be possible to except suits brought under $\S$ I 983 from the wooden incorporation of state law of collateral estoppel without adopting a per se rule allowing relitigation. A functional approach would necessitate inquiry into the opportunity and incentive fully and fairly to litigate a matter in the state proceeding, see Restatement (Second) of Judgments, supra note 3, $\S 68 . \mathrm{I}$, and, of course, would not foreclose creation of exceptional categories where relitigation might be presumptively allowed. However, such an approach would involve elaborate hearings preliminary to consideration of the merits. See, e.g., McCormack, supra note I2, at 276-77 (applying a functional analysis of seven factors). Moreover, it is doubtful that such hearings will disclose the subtle biases whose probable existence is a premise of any exception; to the extent that they would, such hearings might represent a substantially greater affront to the state courts than a per se rule, $c f$. City of Greenwood v. Peacock, 384 U.S. 808, 828 
the incentives created by the absence of such a rule. Because federal constitutional claims will most frequently be raised before state forums as defenses to criminal prosecutions or civil enforcement proceedings, and because collateral estoppel generally applies only to issues actually litigated, application of traditional issue preclusion in subsequent section 1983 actions may provide an incentive to state defendants not to raise their constitutional defenses in the state proceeding. In such proceedings, litigants would be forced to choose between asserting their constitutional objections, thus risking an adverse state court ruling that would effectively preclude a later federal action, and withholding the defense to preserve a later federal suit, thus increasing the risk of adverse state judgment. The latter choice will often seem the lesser of two evils to state defendants, particularly in cases where the state court may be less sensitive than a federal forum to constitutional claims ${ }^{42}$ and the defendant is more concerned with obtaining a favorable declaration of his future rights than with avoiding punishment in the state prosecution. ${ }^{43}$

To structure the litigation incentives to dissuade the assertion of federal claims in state court can hardly serve any justifiable interest of the state; certainly, the just prosecution of state laws is not enhanced by a system which discourages the litigation of constitutional defenses. And the alternative of requiring litigants to raise all constitutional issues in the state court ${ }^{44}$ is no more attractive, for it would impair a defendant's ability to adopt a defense strategy which might allow him to reduce the likelihood of conviction or severe punishment. ${ }^{45}$ Indeed, the willing-

(r g66) (allegations of bad faith prosecution not sufficient to support removal under the civil rights removal statute, 28 U.S.C. $\$ 1443$ (1970), since the statute "does not permit the judges of the federal courts to put their brethren of the state judiciary on trial").

${ }^{42}$ For example, when due process objections are raised in a state criminal trial, the primary inquiry into guilt may color incidental rulings on the defendant's federal procedural rights. See Shaefer, Federalism and State Criminal Procedure, 70 Harv. L. Rev. I, 6-7 (1956); Neuborne, supra note 40, at II 25-26. Moreo er, an institutional bias of the state court judge might derive in part from his knowledge of the commitment of the state's resources that accompanies the decision to bring the prosecution. See Developments in the Law-Federal Habeas Corpus, supra note 33, at ro6r n.rig. See generally F. Miller, Prosecution: The Decision to Charge a Suspect with a Crime (1969). State courts also may exhibit a parochial preference for the enforcement of state substantive law and a consequent insentivity to federal rights raised defensively. See ALI, StUdy of the Division of Jurisdiction Between State and Federal Courts i66 (1969).

${ }^{43}$ See, e.g., Ellis v. Dyson, 42 I U.S. 426 (1975).

${ }^{44}$ Such a theory was rejected in Maynard v. Wooley, 406 F. Supp. I38I, 1385 n.6 (D.N.H. I976) (three-judge court), aff'd, 45 U.S.L.W. 4379 (U.S. April 20, I977).

${ }^{45}$ For example, in Ellis v. Dyson, 421 U.S. 426 (1975), plaintiffs, prior to their 
ness to forgo constitutional defenses is often a critical element in reaching plea agreements. ${ }^{46}$ Clearly an individual who takes advantage of such plea negotiations should not be foreclosed from ever receiving an adjudication of his future rights or of his claims to relief not available in the state proceeding. If he were, a defendant would be forced to choose between alternatives neither more attractive nor more justifiable than those presented by application of traditional rules of claim preclusion.

Nonetheless, it might be argued that a collateral estoppel exception to section 1738 would trivialize the Younger doctrine by limiting the effect of state determinations to the validity of the judgment in the state suit itself. Certainly, if one took an expansive view of Younger and its progeny, and accepted without question the parity of state and federal courts, the relitigation of issues in federal court might be viewed as not only an unnecessary waste of judicial resources, but also an impermissible affront to state courts. But affronts of this nature do not necessarily implicate the Younger doctrine to any substantial degree. First, as argued above, ${ }^{47}$ the Younger doctrine does not extend to suits in which the state court defendant seeks relief unavailable in the normal course of state proceedings, notwithstanding the potential indirect impact on pending state proceedings. ${ }^{48}$ Moreover, as the Court's decision in Doran v. Salem Inn, Inc. ${ }^{49}$ and the limitations properly imposed on derivative preclusion illustrate ${ }^{50}$ Younger does not preclude federal courts from deciding questions of fact and law which are simultaneously at issue in pending state proceedings. Indeed, in Doran, Justice Rehnquist, discussing the possibility of inconsistent judgments on identical claims brought by similarly situated parties in state and federal suits, noted that "the interest in avoiding conflicting outcomes in the litigation of similar issues, while entitled to substantial deference in a unitary system, must of necessity be subordinated to the

federal action challenging a state loitering statute, had pleaded nolo contendere to a prosecution under the statute and were each fined $\$ 10.00$ and $\$ 2.50$ in costs, id. at 428 . They were entitled to a trial de novo but would have been subject to a maximum fine of $\$ 200$, id. at 429 , which they elected not to risk. In systems without two-tier trials, there is the general likelihood of a more severe penalty if one puts the state to trial than if one pleads guilty.

${ }^{46}$ See Note, Plea Bargaining and the Transformation of the Criminal Process, 90 Harv. L. Rev. 564, 573 (1977).

${ }^{47}$ See pp. 1318-22 supra.

${ }^{48} \mathrm{~A}$ state court might find a federal judgment persuasive, even though not formally binding, and federal findings may have some evidentiary value in the state proceeding. See C. McCormICK, supra note 37, \& 318.

49422 U.S. 922 ( 1975 ).

${ }^{50}$ See pp. 1314-17 supra. 
claims of federalism in this particular area of the law." 51 Tolerance for inconsistency, then, is required by the overlapping but distinct interests of state and federal jurisdiction in the federal system.

More basically, the distinction between the treatment of collateral attack and collateral estoppel is one that makes a good deal of sense in Younger terms. By immunizing the judgments of state courts from subsequent federal nullification, the application of section 1738 protects the state's interest in the enforcement of its substantive policies and avoids serious affront to the state courts by rendering their judgment as to the legality of defendant's past conduct final. But as Steffel v. Thompson ${ }^{52}$ makes clear, while the Younger doctrine may be invoked justifiably to foreclose a state court defendant from seeking to undermine or abort a pending state proceeding where the remedy available to him in the normal course is adequate, it is not a mandate to prefer state court resolution of issues related to state action and policies at all costs. ${ }^{53}$ Once one moves from the area in which concerns for comity, efficiency, and the unimpeded operation of the state criminal justice system are most strongly implicated, it becomes increasingly unjustifiable to override section r 983 's provision of a meaningful choice of forum for challenges to the constitutionality of state action.

This does not mean, of course, that individuals should always be free to relitigate issues of fact and law determined in state proceedings. Since section 1983 guarantees, at most, only the choice of a federal forum for constitutional challenges, a collateral estoppel exception to section 738 should not apply to those litigants who voluntarily brought their claims in the state courts. Since they have chosen a state forum initially, it seems fair to consider them to have waived any right to choose a federal one. ${ }^{54}$

${ }^{51} 422$ U.S. at 928 . Justice Rehnquist suggested that a federal declaration that a state statute was unconstitutional while the state was still successfully prosecuting other persons under the statute, was a tolerable consequence of the procedural rules announced in Doran and earlier cases. See pp. 1306-08 supra. That inconsistency does not depend on an exception to the usual rules of collateral estoppel, as would the proposal in text. Justice Rehnquist's proposition does admit, however, that the separability of state and federal interests creates a tolerance for inconsistency and inefficiency that would not exist in a unitary jurisdiction. See 422 U.S. at 928.

${ }^{52} 4 I_{5}$ U.S. 452 ( I 974 ).

${ }^{53}$ See pp. 1288-92 supra.

${ }^{54}$ Thus, a finding of estoppel in Parker v. McKeithen, 488 F.2d 553 (5th Cir.), cert. denied, $4 \mathrm{1} 9$ U.S. 838 (1974), a case where the federal plaintiff, prior to bringing a $\S 1983$ action, had initiated an unsuccessful state tort suit, was correct.

Waiver, however, is an ambiguous concept. A state criminal defendant, for example, otherwise an "involuntary" party to a state prosecution, could be viewed as having waived his right to a federal hearing on the constitutionality of the 
Under the proposed exception, collateral estoppel would not bar federal relitigation only where the federal plaintiff was either an involuntary defendant in the prior state proceedings unable to remove the case ${ }^{5 \overline{5}}$ or an involuntary plaintiff forced to exhaust state remedies..$^{56}$

Thus far, the lower federal courts have not recognized an exception to statutory full faith and credit of the scope suggested here. Because their response to the problem of preclusive effect has been erratic, and because the circumstances underlying a plea of collateral estoppel vary, it is useful to consider the two basic categories of section 1983 actions raising collateral estoppel questions to highlight further both the problems of current practice and the contours and operation of the proposed exception.

I. Nonparallel Actions: Declaratory Judgments Subsequent to State Proceedings. - Samuels v. Mackell's ${ }^{57}$ holding that an action for a declaratory judgment as to the unconstitutionality of a statute underlying a pending state proceeding is precluded by the Younger doctrine combines with the timing rule of Hicks v. Miranda ${ }^{58}$ to foreclose federal declaratory relief to plaintiffs who are currently the targets of state enforcement actions and to those who are charged shortly after the initiation of their section I 983 suit. Whatever the wisdom of requiring the plaintiff to litigate the legality of his past conduct in state court, there seems little reason to prevent him from receiving a subsequent federal declaration of his future rights, whether or not he actually litigated the constitutional issue in state court. In Thistlethwaite $v$. City of New York ${ }^{59}$ however, the Second Circuit held that a defendant who had litigated his constitutional claim in the state

statute under which he is being prosecuted by engaging in the proscribed conduct rather than seeking federal anticipatory relief. See The Supreme Court, I974 Term, 89 Harv. L. REv. 47, 167-68 (1975). Using the concept of waiver in this context, however, is formalistic, unfair, and unwise. It depends on the artificial view that individuals generally can foresee possible confrontations with the law and arrange their affairs sufficiently far in advance to obtain a declaratory judgment prior to engaging in proscribed conduct. Moreover, to comport with reality, such a waiver doctrine would require a highly factualized inquiry in hearings preliminary to the merits to determine whether the state defendant could have obtained declaratory relief before violating the statute.

${ }^{55}$ See p. 1336 \& n. 27 supra.

${ }^{56}$ See, e.g., Preiser v. Rodriguez, 4II U.S. 475 (1973); statutes cited note 29 supra.

${ }^{57} 401$ U.S. 66,72 (I97I).

58422 U.S. 332,349 (1975); see pp. I30I-06 supra.

${ }^{59} 497$ F.2d 339 (2d Cir.), cert. denied, 4I9 U.S. I093 (1974). The plaintiffs had not sought direct review of their convictions by the Supreme Court. 497 F.2d at $34 \mathrm{I}$. The Second Circuit assumed that all of the issues raised by the $\S$ I 983 suit for declaratory relief had been litigated and decided adversely to the plaintiffs in state court, $i d$. at $34 \mathrm{r}-42$, an assumption disputed by the dissent, id. at $343-44$. 
court could not then bring a federal action to have the state's criminal statute declared invalid. ${ }^{60}$ In doing so, the court rejected the arguments that the issue of the law's prospective effect to be determined in the federal action was distinct from the issue previously litigated, that congressional policies underlying the Civil Rights Act overcame the competing interests in finality, and that collateral estoppel should be applied only if the I 983 plaintiff had had a choice of forum in the prior suit. ${ }^{61}$

The Thistlethwaite conclusion is questionable on a number of grounds. First, as noted, the application of collateral estoppel contemplated by Thistlethwaite would provide an incentive for state defendants not to raise their constitutional defenses when their principal concern is with future conduct - a result which cannot be justified in light of any legitimate policies of state law enforcement. But it would be arguably more unjust to relieve this incentive "to stand mute in the dock" by barring the declaratory judgment action if the constitutional defense had not been raised before the state court. Recently the Supreme Court in Wooley v. Maynard ${ }^{62}$ rejected the argument that Huffman v. Pursue, Ltd. ${ }^{63}$ which had required exhaustion of state appellate remedies as a necessary if not sufficient condition for impeaching a state judgment, ${ }^{64}$ should be extended to require that state appellate remedies be pursued before the underlying statute is made the subject of a declaratory judgment in federal court. Although Wooley was decided under the rubric of the Younger doctrine, its analysis strongly supports the exception to collateral estoppel proposed here. In Wooley, the Court distinguished between federal suits "designed to annul the results of a state trial" and those where "the relief sought is wholly prospective." ${ }^{65}$ The latter, it held, were permissible since they did not deprive the state of the legitimate function of "overseeing trial court dispositions of constitutional issues arising in civil litigation over which they have jurisdiction." 66 In just the same manner, the proposed collateral estoppel exception would not intrude into the state trial and appellate functions, but would permit an untrammeled federal jurisdiction for wholly prospective relief.

${ }^{60} 497$ F.2d at 342 .

${ }^{61} \mathrm{Id}$, at $34 \mathrm{I}-42$.

${ }^{62} 45$ U.S.L.W. 4379 (U.S. April 20, 1977), aff'g 406 F. Supp. I38I (D.N.H. I976) (three-judge court). The Court stressed that the reasoning of $H$ uffman was inapposite to declaratory relief which leaves the state judgment unaffected. Id. at $438 \mathrm{I}$.

\footnotetext{
${ }^{63} 420$ U.S. 592 (1975).

${ }^{64} 420$ U.S. at 608.

${ }^{65} 45$ U.S.L.W. at $438 \mathrm{I}$.

${ }^{66} I d$.
} 
To be sure, concerns for state self-correction, judicial economy, and respect for the competence of state courts may argue in favor of final state adjudication of challenges to states' laws and practices. Such a result, however, is more likely to be accomplished under the proposed exception to section 1738 than under the rule in Thistlethwaite. And while the exhaustion rule rejected by Wooley might as effectively remove the incentive to withhold constitutional defenses, it seems entirely inconsistent with the policy of declaratory relief which permits the dissociation of the criminal prosecution from the scrutiny of the constitutionality of the state law. ${ }^{67}$

Moreover, even where state and federal courts reach conflicting results, the conflict relates not to the characterization of a historical transaction, as is usually the case where collateral estoppel is invoked, but rather to a continuing question of law. Conflicts over purely legal questions are quite common in a dual system, and the policies in favor of finality have little force in such cases. Certainly, no legitimate interest is advanced by attempts to immortalize a state's questionable interpretations of federal law. Indeed, the Second Restatement of Judgments recognizes that the rationale for collateral estoppel is weak in cases seeking only to reopen an issue of law; ${ }^{68}$ it would allow relitigation of issues of law in subsequent suits involving different transactions. Finally, the state's interest in the integrity of its law is not substantially impaired by permitting a prior criminal defendant to relitigate questions of federal law. While finding another proper plaintiff may be difficult ${ }^{69}$ any other person presenting a justiciable controversy could obtain the same declaration. And, of course, the original defendant could relitigate the constitutionality of the statute, as a defense, were he again prosecuted. Withholding the opportunity to challenge the law in a declaratory judg-

\footnotetext{
${ }^{67}$ See, e.g., Steffel v. Thompson, 415 U.S. $453,462-73$ (1974); pp. I 288-92 supra.

${ }^{68}$ Restatement (SECONd) of JUdGments, supra note 3 § 68.I(b), Reporter's Note at 185 . The analogy to the Second Restatement depends upon conceptualizing the controversy over contingent future rights as arising out of a "transaction" separate from the historical subject matter of the criminal prosecution. If so conceived, the more flexible principle of stare decisis would be sufficient to avoid vexatious litigation, at least in the courts of the same jurisdiction, id., Comment b at 174 , and summary consideration could be given in federal court if necessary to contain unmeritorious declaratory suits following state convictions.

${ }^{69}$ Given the stringency of present justiciability requirements, see generally pp. I292-94 supra, a declaratory judgment plaintiff might most easily show a sufficient threat of prosecution if he has been previously convicted under the challenged statute. See Petition for Writ of Certiorari at 13, 14, Thistlethwaite v. City of New York, 497 F.2d 339 (2d Cir.), cert. denied, 4I9 U.S. I093 (1974).
} 
ment action may serve only to encourage future violations of the law or to chill conduct which may be constitutionally protected.

A different case is presented where federal declaratory relief would amount to collateral attack on the final judgment and order of the state court. ${ }^{70}$ In the normal case, the declaratory judgment has no impact on the prior conviction; the state court defendant cannot secure either reimbursement of fines paid ${ }^{71}$ or removal of his conviction on the basis of a later federal declaration of his future rights, and is precluded from seeking such redress directly in federal court by the application of merger and bar. $^{72}$ But where the state court decree takes the form of an injunction against future conduct, a federal declaratory judgment that the underlying statute is unconstitutional, if accorded res judicata effect in a subsequent state prosecution or contempt proceeding, would effectively impeach the state court order. And if the federal judgment were not res judicata in a subsequent proceeding, the declaratory judgment would be a largely meaningless exercise by the federal court. ${ }^{73}$ In either case it seems that federal declaratory relief should be unavailable. The facts in Huffman v. Pursue, Ltd $^{{ }^{\mathbf{7 4}}}$ fit this pattern: after the state trial court entered a final judgment against the owner of a movie theatre and enjoined future operations, the owner, instead of appealing, brought a section 1983 action for a declaratory judgment that the statute under which he was convicted was unconstitutional and for an injunction against the state judgment. ${ }^{75}$ The Supreme Court, avoiding consideration of res judicata directly, held that even were there to be an opportunity for collateral review, it would not be occasioned until state appellate remedies were exhausted. ${ }^{76}$ While one might dispute the fairness of applying the new exhaustion rule in $H u f f m a n$ itself, ${ }^{77}$ foreclosure of access to federal court seems entirely appropriate in that case, since even a declaratory judgment would have undermined the state court order. ${ }^{78}$ But as noted earlier, that case

${ }^{70}$ See pp. $1336-37$ supra.

${ }^{71}$ A suit for restitution of a criminal fine would probably be barred also by the eleventh amendment. See pp. I195-97 supra.

72 See pp. $1332-33 \&$ n.7 supra.

${ }^{73} \mathrm{See}$ p. 1357 infra.

${ }^{74} 420$ U.S. 592 (1975).

75 Id. at 598 .

${ }^{76}$ Id. at $606-08$.

${ }^{77}$ The Court failed to inquire into the continued availability of appellate relief in the state courts. $I d$. at 6 I I n.22.

${ }^{78}$ If federal declaratory judgments were binding upon a state, see pp. $13 \div 4-60$ \& n.I2I infra, then a federal judgment inconsistent with prior state injunctive relief might be accorded res judicata effect in a third action, see Restatement (Second) of Judgments, supra note $3, \S 4 \mathrm{r} .2$, having the effect of displacing the 
should not be read to foreclose relitigation of issues of law which would not undermine the state court decision as to prior conduct, ${ }^{79}$ whether or not the issues were raised as a defense in the state proceeding.

2. Parallel State and Federal Suits. - Frequently, suits arising out of the same transaction will be brought in both state and federal courts. This will necessarily be the case whenever an individual is forced to litigate in a forum which is unable to grant certain types of relief to which he may be entitled. Thus a criminal defendant, confined to state court by the Younger doctrine, will be required to resort to another suit - often brought in federal court - to obtain damages or equitable relief against state officials. Similarly, a state prisoner challenging his confinement in a state court action, as he is required to do by 28 U.S.C. $\S 2254^{80}$ before seeking federal habeas corpus relief, must ordinarily bring a separate action to obtain damages or other affirmative relief. The Younger doctrine and the exhaustion requirement of federal habeas corpus embody a substantial interest in avoiding federal relief in these contexts which would abort or otherwise supersede the state proceeding.

In a regime where ordinary principles of res judicata applied, issues underlying the first of these judgments to become final would be given collateral estoppel effect in the other suit according to the law of the forum that rendered the judgment. ${ }^{81}$ If the federal suit were concluded first, its findings would ordinarily not be conclusive on the state, since the state usually will have been neither a party to that suit nor in privity with the section r983 defendant. ${ }^{82}$ Indeed, were it otherwise, the maintenance

injunction or avoiding a contempt citation for its disregard. Thus where a state court has fashioned prospective relief, a federal declaratory judgment that the underlying law is unconstitutional should be barred by claim preclusion, see id. § $4 \mathrm{I}$, Comment $\mathrm{c}$, at $3-4$, though ordinarily relief will be available in the state court if there are changed circumstances, id. $\S 6 \mathrm{I}$, Comment $\mathrm{f}$, or other equitable grounds for setting aside the judgment. The federal court should be sensitive, however, to the possibility of the state court's foreclosing federal court review of arguably unconstitutional state statutes through the artifice of incorporating those laws into simple prohibitory injunctions.

${ }^{79}$ See pp. 1338-4I supra.

8028 U.S.C. $\$ 2254$ (b), (c) (1970).

${ }^{81}$ See Kline v. Burke Construction Co., 260 U.S. 226, 230 (1922) ; Restatement (Second) of Conflicts of Laws $\S 86$, Comment a (1969); ia J. Moore, supra note 3 , If 0.221 , at 2606 n.4. As discussed above, pp. 1333-34 supra, the effect to be given a prior state judgment is ordinarily determined with reference to state law via $\S \mathrm{I} 738$. The effect of a prior federal judgment, at least when rendered in a federal question case, is a matter of federal common law, see note 129 infra.

${ }^{82}$ Suits under § 1983 may not be maintained against most governmental units because of either eleventh amendment immunity or the judicial construction of 
of the federal suit might well be impermissible under Younger or section 2254 .

But while the state cannot be precluded by the federal court's findings in a private suit litigating such issues as the damages to be awarded for an allegedly illegal search and seizure, the reverse is not the case; under the currently prevailing view, the section I 983 plaintiff would be estopped in his federal suit by adverse

the word "person" within $\S 1983$. Of course, some suits may still be brought against state officials in their representative capacities. See pp. I196-97 \& n.45 supra. Whether a state or municipality is bound by a judgment in a $\S$ r 983 action against a public official depends on the legal capacity in which the defendant official was sued and arguably on the degree of control exercised by the state over the defense of the action. See Restatement (Second) of Judgments $\$$ 80, 83 (Tent. Draft No. 2, 1975). Suits properly brought against public officers in their official capacity for equitable relief are conclusive on the government and on the official's successors, see, e.g., Tait v. Western Md. Ry., 289 U.S. 620 (I933); Gunn v. United States, 283 F.2d 358 (8th Cir. ig6o) ; Restatement (Second) of Judgments $\$ 80$, Comment e, Reporter's Note at 29 (Tent. Draft No. 2, 1975), and are accordingly prohibited under some circumstances by the Younger doctrine. See generally pp. II97-99 supra. On the other hand, when the \& 1983 suit seeks to impose personal and individual liability against the named defendants, the official will participate in his individual capacity and the judgment will not be conclusive on the state. See Restatement (Second) of Judgments $\$ 80$, Comment e (Tent. Draft No. 2, 1975). Therefore, if a preclusive effect against the state or municipality is sufficient under some circumstances to bar a $\S 1983$ suit, the court should view the kind of relief sought as determinative of the legal capacity of the public official in the suit. If relief is sought against the official in both his official and individual capacities, as in a suit for damages and injunctive relief, the damage action might be tried separately, if it would be prejudicial to stay entire suit pending the completion of the state proceedings. See Fed. R. CIv. P. 2I. In that case the plaintiff would not be precluded from thus "splitting" his cause of action. See Restatement (Second) of Judgments $\$ 80$, Comment a (Tent. Draft No. 2, 1975).

This "legal capacity" analysis is problematic in the context of habeas corpus relief for state prisoners where the Supreme Court has allowed $\S$ I 983 suits against prison administrators in their official capacities to proceed simultaneously with state postconviction relief sought against the same administrators, see Preiser v. Rodriguez, 4II U.S. 475 (I973); in doing so, the Court purported to preserve the integrity of the habeas exhaustion requirement, 28 U.S.C. \$ 2254 (1970), although with questionable success if, as the dissent supposed, 4 II U.S. at 5 II (Brennan, J., dissenting), a federal judgment would be conclusive on the state. See pp. 135460 infra.

Even where the $\S 1983$ suit is brought against an official exclusively in his individual capacity, the state or municipality arguably would be bound by the judgment if it substantially controlled the defense of the suit. See Restatement (Second) of Judgments, \& 83 (Tent. Draft No. 2, I975). Although the finding of control ordinarily does not require that the controlling party have a proprietary interest in the subject matter of the suit, compare id. with RESTATEMENT OF JUDGMENTS $\S 84$ (I942), often circumstantial evidence of control will be provided by an agreement with the state to indemnify the official for certain types of liability or to supply legal defense. However, it would seem more advisable to inquire into the congruence of the underlying substantive interests of the official and the state, 
state court findings ${ }^{83}$ if the state did not require mutuality to apply collateral estoppel. ${ }^{84}$ Obviously, the estoppel would run only one way, leaving the state hearing unimpeded; nevertheless, some federal courts, invoking principles of comity and federalism, have stayed federal suits which might "embarass [or] intrude into" state procedings, ${ }^{85}$ despite the absence of any legal binding effect. While such a stay of the federal suit might sometimes be appropriate if the proposed exception to section 1738 were adopted, ${ }^{86}$ it would otherwise be highly prejudicial to the federal plaintiff without being justified by any need to immunize the state suit from res judicata.

The proposed exception to section 1738 would largely relieve the possible prejudice resulting from the combined effect of a "race to the courthouse" with a one-way estoppel. Concededly, this exception may result in an inconsistency between federal and state decisions. But such inconsistencies, while striking because they may relate to a single past transaction, will be infrequent, and when they do occur are justified by the importance of vindicating federal rights. Since more must be shown to recover damages than the mere illegality of the conduct in question, ${ }^{87}$ a state decision favoring the federal plaintiff's claim is not necessarily inconsistent with a federal judgment denying damages. Real inconsistency exists only where the state court has upheld the legality of the challenged conduct while the federal court has

which in the case of an adjudication of personal liability incidentally implicating questions of the legality of state action, would be quite distinct. See generally Restatement (Second) of Judgments \& 83, Comment a (Tent. Draft No. 2, 1975). The "interest" analysis suggests that it would be inappropriate to bind the state prosecutors, for example, by a finding in a $\$ 1983$ fourth amendment damage action brought against policemen that a search was made illegally, even if the state provided the defense. Indeed, if the state were bound in such a case, the $\S 1983$ suit would probably be barred by Younger. Just as the voluntary agreement by the state to indemnify its officers for $\S 1983$ liability should be insufficient to create an eleventh amendment immunity, see Tribe, Intergovernmental Immunities in Litigation, Taxation, and Regulation: Separation of Powers Issues in Controversies About Federalism, 89 HaRv. L. REv. 682, 686 n.52, (1976), so should the state not be permitted to bar otherwise permissible federal civil actions via a "purely intramural arrangement with its officers," id., creating jural privity.

${ }^{83}$ See p. $1336 \&$ n.27 supra.

${ }^{84}$ See p. 1338 \& n.37 supra.

${ }^{85}$ Guerro v. Mulhearn, 498 F.2d 1249, 1253 (Ist Cir. 1974); Fulford v. Klein, 529 F.2d 377, rehearing en banc granted, 529 F.2d 384 (5th Cir. 1976); Meadows v. Evans, 529 F.2d 385, rehearing en banc granted, 529 F.3d 387 (5th Cir. 1976); Grundstorm v. Darnell, 53 F.2d 272 (5th Cir. 1976).

${ }^{86}$ See pp. 1334-43 infra.

${ }^{87}$ Ordinarily the good faith and reasonableness of the conduct in question will be put in issue. See pp. 1204-17 supra. 
awarded damages under section $1983 .{ }^{88}$ Such cases are improbable. If the facts arguably would support a state court finding of the conduct's legality, ordinarily the official would be entitled at least to a federal finding of reasonableness - particularly if the state proceeding were concluded first and its finding admissible in the federal suit. ${ }^{89}$ Where the federal court finds the defendant to have acted in bad faith or in violation of the plaintiffs' clearly settled constitutional rights, that finding may suggest that the state court decision constituted an egregious error. To the extent that this is true, the state decision deserves little deference and the concern for affront to presumably competent forums becomes increasingly attenuated. ${ }^{90}$

Of course, where a federal finding casts doubt on the defendant's guilt, his continued incarceration may seem difficult to justify. The fourth amendment presents an easy case in this respect because correct application of the exclusionary rule, while it may affect the likelihood of conviction, does not also affect the likelihood of actual guilt. ${ }^{91}$ Moreover, since the Supreme Court has largely excluded state violations of the exclusionary rule from the scope of federal habeas corpus, ${ }^{92}$ section 1983 damage actions may be the only remaining means for the federal

${ }^{88}$ Ordinarily the adverse state judgment would not be susceptible to federal collateral review unless it has resulted in such continuing restraint as to bring the case within the federal habeas jurisdiction. See Carafas v. LaVallee, 39r U.S. $234,237-40$ (1968). See generally pp. I332-33 \& n.7. Thus, the adverse state judgment commonly would stand while a state defendant sought damages under $\S \mathrm{I} 983$ for a deprivation which often would underlie the state judgment. For example, such results might obtain where damages were sought for an illegal search and seizure, e.g., Guerro v. Mulhearn, 498 F.2d I249 (Ist Cir. I974), perjury by an official at the criminal trial, id., withholding of possibly exculpatory evidence, e.g., Fulford v. Klein, 529 F.2d 377, rehearing en banc granted, 529 F.2d 384 (5th Cir. I976), or the denial of right to counsel, e.g., Grundstrom v. Darnell, 53 I F.2d 272 (5th Cir. I976).

${ }^{89}$ See Fed. R. Evid. § 803 .

${ }^{90}$ The paradox of inconsistent judgments is most apparent if the damages awarded in the $\S \mathrm{I} 983$ suit were intended to compensate for the penal consequences of the state judgment. Cf. Fulford v. Klein, 529 F.2d 377, 38I (dictum) (damages for denial of good time credits not available prior to seeking habeas corpus relief), rehearing en banc granted, 529 F.2d 384 (5th Cir. 1976). Such a recovery is unlikely since, apart from the possible defenses and immunities, it may be difficult to establish causation. However, if recovery is allowed, the result is justified by the interest in deterring unconstitutional police conduct, an interest separable from adjudication of state criminal liability.

${ }^{91}$ The fourth amendment presents an "easy" case only upon the view that the exclusionary rule is not a personal constitutional right. See Stone v. Powell, 428 U.S. 465, 486 (1976). But see id. at 502 (Brennan, J., dissenting) ; Note, Formalism, Legal Realism, and Constitutionally Protected Privacy Under the Fourth and Fifth Amendments, 90 HaRv. L. Rev. 945, 985-9I (I977).

${ }^{92}$ Stone v. Powell, 428 U.S. 465 (1976). 
court to assist in policing fourth amendment violations. Even where the federal plaintiff seeks damages for a violation of his constitutional rights which goes to the accuracy of his conviction, however, application of collateral estoppel is not mandated. First, such suits will be extremely rare: most would have to be brought against the prosecutor or judge, both of whom enjoy absolute immunity from damage actions under section $1983 .{ }^{93}$ Second, federal habeas corpus provides a means for the plaintiff to secure a federal redetermination of the constitutionality of his confinement itself, thus relieving the apparent paradox.

The elimination of collateral estoppel effect in section 1983 actions should exert a practical impact on the relative timing of federal and state litigation. Absent collateral estoppel, state criminal defendants are more likely initially to concentrate their energies and resources on defending the state court action, rather than to conduct two simultaneous actions. Indeed, it is partly because of this burden of multiple litigation or forgone constitutional defenses that the exception to section $\mathrm{I} 738$ is justified. The question arises, nevertheless, what course a federal court should follow where it is called upon to decide an issue which has not yet been resolved by the state court. In some cases dismissal would be appropriate independent of concerns of comity and res judicata, for want of a justiciable controversy. This might be the case where the alleged deprivation arises out of the state trial itself, ${ }^{94}$ as in the case of perjury impairing the right to a fair trial. A stay also might be appropriate if it were likely that the penalty imposed by conviction would be relevant to the measure of damages for the deprivation. In otherwise justiciable cases, the burdens placed on the federal plaintiff if the proceeding is stayed render the stay wholly unjustifiable absent an exception to section I738. But if collateral estoppel against the federal plaintiff were eliminated, the argument for staying the federal proceeding would become more compelling. In that case, neither party would be bound by collateral estoppel: the only impact of one decision on the other would be the practical and evidentiary weight of a prior judicial decision on the same issue and the question would become whether as a rule the federal suit should be subjected to that effect.

${ }^{93}$ Imbler v. Pachtman, 424 U.S. 409 (1976) (prosecutors) ; Pierson v. Ray, 386 U.S. 547 (1967) (judges); see pp. I197-1204 supra.

Of course, if $\S \mathrm{I} 983$ suits could be maintained against municipalities under an amended or reconstrued statute, or directly under the fourteenth amendment, see pp. II9I-97 supra, the preceding analysis would be inapposite. Under those circumstances it would be less plausible to deny collateral estoppel effects running against either litigant.

${ }^{94}$ See cases cited note 26 supra. 
In the context of a fourth amendment damage suit, it is difficult to see any reason for a stay. The deprivation is consummated at the instant of the intrusion, and an award of consequential damages to compensate for a penalty predicated upon improperly admitted evidence is unlikely. Given the unavailability of federal habeas review, the significant federal interest in vindicating fourth amendment claims is increasingly dependent upon such civil actions. On the other hand, the state's interest in enforcing its substantive law is in no way jeopardized by prior conclusions of federal courts that do not formally bind the state. Moreover, the maintenance of the federal action suggests no affront to state courts - the independent civil action is required simply because of the unavailability of damage relief in state criminal court.

The permutations of state and federal proceedings giving rise to potentially conclusive findings are more numerous in the case of prisoner's suits. Parallel actions may result from the Supreme Court's distinction between relief which may be obtained under section 1983 and that which is available only through habeas corpus. Preiser v. Rodriguez ${ }^{95}$ held that when a state prisoner challenges the fact or duration of his confinement, habeas corpus is the exclusive federal remedy. ${ }^{96}$ This conclusion was said to be mandated by the strong state interest in the administration of its prisons ${ }^{97}$ - an interest which the habeas exhaustion requirement of section 2254 protects by giving state administrative and judicial organs the first opportunity to hear challenges to state confinements. Damage remedies, however, as well as equitable relief other than release, were distinguished as being the proper subject of a section 1983 suit. $^{98}$ As the dissent noted, ${ }^{99}$ the Preiser solution bifurcating litigation over a single controversy according to the relief sought would generate severe anomalies if, as the Court suggested, conventional principles of collateral estoppel were to apply. ${ }^{100}$

A prisoner's section 1983 suit typically arises either out of the circumstances underlying his conviction, as in the case of a damage

\footnotetext{
${ }^{95} 4$ II U.S. 475 (1973).

${ }^{96} \mathrm{Id}$. at 500 .

${ }^{97} I d$. at $49 \mathrm{I}-92$.

${ }^{98}$ Id. at 494; Wolff $\mathrm{v}$. McDonnell, 418 U.S. 539, 554-55 (1974).

${ }_{99} 4 \mathrm{II}$ U.S. at $5 \mathrm{II}-\mathrm{I} 2$. Justice Brennan anticipated that determinations in the $\S \mathrm{I} 983$ suit would be binding in the state proceeding. Id. at $5 \mathrm{II}$. This is plausible given the identity of parties in the two suits.

${ }^{100}$ Compare Wolff v. McDonnell, 4 I8 U.S. 539, 554 n.I2 (I974) ("one would anticipate that normal principles of res judicata would apply in such circumstances"), and Preiser v. Rodriguez, 4II U.S. 475, 497 (1973) (dictum) (res judicata has been held fully applicable to $\S 1983$ suits), with id. at 509 n.I4 (Brennan, J., dissenting).
} 
action alleging subornation of perjury, ${ }^{101}$ or out of deprivations pertaining to restraint after conviction, as in the case of a claim for damages for the denial of "good time credits" without due process. ${ }^{102}$ Again, absent an exception to section 1738 , findings made in state postconviction proceedings as well as the original trial would be conclusive on the prisoner in his civil rights suit ${ }^{103}$ - a result which, as argued earlier, would unfairly burden the vindication of federal rights. ${ }^{104}$

An independent federal suit need not undermine the exhaustion requirement of 28 U.S.C. \$ 2254 . Of course, the warden or other similar official frequently will be named as defendant in his representative capacity in a 1983 suit seeking injunctive relief, or if sued personally, will be defended by the state, thus satisfying traditional notions of privity to warrant binding the state. ${ }^{105}$ Nevertheless, as a matter of federal law reconciling section 1983 and 28 U.S.C. $\$ 2254$, findings in a 1983 suit should not be conclusive in the state habeas proceeding.

If the policies underlying section 2254 are sufficient to deny collateral estoppel effect to a prior federal judgment, it is arguable that they should also be sufficient - assuming the application of the proposed exception to section I 738 - to require federal courts to stay parallel 1983 actions whenever habeas is available. If stays were costless, this might be an appropriate resolution. While precedential and evidentiary impact ${ }^{106}$ - as opposed to collateral estoppel - would not undermine the exhaustion requirement, the substantial state interest protected by this requirement may suggest that the federal courts defer any decision which would intrude into the state proceeding. Such stays, however, might work real hardships on the federal plaintiffs. In Wolf $v$. McDonnell, ${ }^{107}$ for example, state prisoners brought a section I 983 action challenging prison disciplinary procedures on due process grounds and seeking damages, the restoration of good time credits, and

${ }^{101}$ See cases cited note 26 supra.

${ }^{102}$ See, e.g., Wolff v. McDonnell, 418 U.S. 539 (1974); Preiser v. Rodriguez, 4 II U.S. 475 ( I 973 ).

${ }^{103}$ But cf. Campise v. Hamilton, 382 F. Supp. 172, 180-83 (S.D. Tex. 1974) (dictum) (doubt whether adverse judgment in state habeas suit should bar $\S$ I 983 action).

${ }^{104}$ It is unsettled whether a successful federal habeas suit removes the collateral estoppel effect of a prior contrary state court determination. See Moran v. Mitchell, 354 F. Supp. 86, 89 (E.D. Va. 1973) (dictum). However, the finding of the habeas court could not be used offensively to estop a person not a party to that proceeding. See Davis v. Eide, 439 F.2d 1077 (9th Cir.), cert. denied, 404 U.S. 843 (I97 I) ; Imbler v. Pachtman, 424 U.S. 409, 428 n. 27 (I976).

105 See p. 1338 \& n.37 supra.

${ }^{106}$ See C. MCCoRmICK, supra note $37, \S 318$.

${ }^{107} 4$ I 8 U.S. 539 (1974). 
other equitable relief. ${ }^{108}$ The Supreme Court held that under Preiser, restoration of good time could not be awarded in a 1983 action since such relief went to the duration of the prisoner's confinement. The action for damages and other equitable relief, however, was permitted to go forward without exhaustion of state remedies. ${ }^{109}$ Were the federal court in Wolff instead to defer decision on the due process question - without granting any interim relief - until the required habeas exhaustion proceedings were completed, the plaintiffs and other inmates would be subjected to an arguably unconstitutional system. Indeed, even in actions seeking only damages, the delay resulting from the grant of a stay pending lengthy state proceedings might jeopardize or at least burden the plaintiff's ability ultimately to establish his right to recovery. What seems needed in such cases, then, is a flexible stay policy through which the federal courts can accommodate the plaintiff's interest in speedy relief with the interests embodied in the habeas exhaustion requirement. Where a hardship of any substance will result from delay, a stay plainly cannot be justified in view of the marginal nature of the intrusion occasioned by a prior federal court decision.

\section{B. The Effect of Federal Declaratory Judgments on State Proceedings}

In Steffel v. Thompson, ${ }^{110}$ the Supreme Court held that when no state proceedings are pending, federal declaratory judgments on the constitutionality of state laws are obtainable regardless of the existence of conditions justifying injunctive relief. ${ }^{111}$ The Court left open, however, the questions of the legal effect of a declaratory judgment ${ }^{112}$ as well as the availability of further

${ }^{108}$ Id. at $553-54$.

${ }^{109}$ Id. at $554-55$.

${ }^{110} 415$ U.S. 452 (1974).

${ }^{111}$ Id. at 462-63. See Wooley v. Maynard, 45 U.S.L.W. 4379 (U.S. April 20, I977) ; Doran v. Salem Inn, Inc., 422 U.S. 922 (1975).

112 Observing that a declaratory judgment might have some res judicata effect, Justice Brennan also noted that the "point is not free from difficulty and the governing rules remain to be developed with a view to the proper workings of a federal system." Steffel v. Thompson, 4I5 U.S. 452, 470-7I (I974) (quoting Perez v. Ledesma, 40I U.S. 82, I25 (197I) (Brennan, J., concurring and dissenting)). Concurring separately in Steffel, Justice Rehnquist purported to express no opinion on the question of res judicata effect, 4 I 5 U.S. at 482 n.3, but did address numerous other related matters not before the Court, opining that the declaratory judgment would not preclude the state from prosecuting the federal plaintiff. Further violations of the statute, according to Justice Rehnquist, would remit the plaintiff to relief in the state prosecution, where the federal judgment could be raised "for whatever value it may prove to have," id. at 482 , presumably just that of a more or less persuasive but nonbinding decision. Injunctive relief against 
relief in the event of threatened or actual prosecutions under a statute previously the subject of such a judgment. ${ }^{113}$ These matters clearly determine the attractiveness of declaratory relief as an alternative to violation of state law followed by defense of a state prosecution.

The threshold determinant of the effect of a Steffel-type judgment is the nature of the constitutional defect declared. A federal plaintiff may seek a declaration that a state statute is unconstitutional on one or more of four grounds. First, the statute may be attacked "as applied" to certain of the plaintiff's conduct. ${ }^{114}$ The gravamen of an "as applied" challenge is that the plaintiff's past or contemplated conduct is constitutionally protected; as a result, a declaration to that effect is not conclusive with regard to the permissibility of reaching other conduct under the statute. Second, if the statute allegedly proscribes only constitutionally protected activity, it may be declared facially invalid in toto. The declaration would reflect the opinion that there are no permissible applications of the statute. Third, a statute purporting to reach both protected and unprotected activity would be objectionable on its face as unconstitutionally overbroad. $^{115}$ A substantially overbroad statute may not be applied even to unprotected conduct until it has been given a sufficiently narrowed construction. Thus, unlike "as applied" adjudications, a declaration of overbreadth is in one sense contingent: the immunity from prosecution is dependent on the statute's infirmity, not on the lawfulness of the plaintiff's conduct. ${ }^{116}$ Fourth, a statute which is sufficiently vague might be declared unconstitutional on its face, having no permissible application until a re-

such a prosecution would be available only if the showing required by the Younger cases were made, $i d$. at 483 , and a prosecution itself would not be indicative of prosecutorial bad faith sufficient to justify an injunction, id. Justice White, writing "in light of" Justice Rehnquist's opinion, suggested that a final declaratory judgment should be accorded some res judicata effect in later prosecutions, id. at 477 , and that injunctions might be available against such prosecutions, $i d$. at 477-78. Two lower federal courts have suggested that such a declaratory judgment would be res judicata between the parties to the suit. See YWCA v. Kugler, 463 F.2d 203, 204 (3d Cir. 1972) (declaratory judgment binding only on parties), cert. denied, 4I5 U.S. 989 (I974); United States ex. rel. Lawrence v. Woods, 432 F.2d 1072, 1076 (7th Cir. 1970) (dictum), cert. denied, 402 U.S. 983 (I97I).

${ }^{113}$ See pp. 1296-1300 supra.

${ }^{114}$ See Note, The First Amendment Overbreadth Doctrine, 83 HaRv. L. REv. $844,847-52$ (1970).

${ }^{115}$ See Erznoznik v. City of Jacksonville, 422 U.S. 205, 2 I6 (I975); Broadrick v. Oklahoma, 4I3 U.S. 60I (1973).

116 Thus a valid narrowing construction may be applied even to conduct occurring prior to the date when the narrowing construction was obtained, provided such application affords fair notice. Younger v. Harris, 40r U.S. 37, $5 \mathbf{r}$ (I97I) ; Dombrowski v. Pfister, 380 U.S. 479 n.7 (I965). 
habilitating construction has been obtained. The infirmity of an impermissibly vague statute is not that it purports to reach protected activity, ${ }^{117}$ but that it violates due process by not providing fair notice of its reach or standards for its enforcement. ${ }^{118}$

The nature of the declared constitutional shortcoming will determine the permissibility of a subsequent prosecution under the statute apart from any res judicata effect the judgment may be given. A declaratory judgment that a statute is vague or overbroad is not inconsistent with a subsequent prosecution, so long as a narrowing construction has been obtained or is sought through that prosecution. ${ }^{119}$ And of course, objections to the statute as applied to certain conduct will not foreclose other applications.

Whatever the grounds for declaring a statute unconstitutional, a declaratory judgment derives its legal effect from two sources. First, if the judgment has been affirmed by the Supreme Court, it is binding on all state courts as controlling authority under the supremacy clause ${ }^{120}$ and the Supreme Court would reverse any subsequent impermissible application of the statute sustained by the courts of the state. While such disregard by state authorities of controlling decisional law is highly unlikely, ${ }^{121}$ further federal relief might be warranted if the state does proceed with a prosecution. ${ }^{22}$

When a judgment in favor of the plaintiff has not been ap-

${ }^{117}$ However, in the context of first amendment rights, the defects of overbreadth and vagueness often are practically indistinguishable. See Note, supra note 114 , at 873 .

118 See Note, The Void for Vagueness Doctrine in the Supreme Court, 109 U. PA. L. Rev. 67 (1960). The Court has recently limited the availability of standing to challenge regulations of speech on vagueness grounds. See Young v. American Mini Theatres, Inc., 427 U.S. 50 (1976).

${ }^{119} \mathrm{See}$ Younger v. Harris, 40I U.S. 37, 5 I (197I).

120 U.S. Const. art. VI, cl. 2 ; see Perez v. Ledesma, 40I U.S. 82, 124-26 (197I) (Brennan, J., concurring and dissenting). The judgment is not less binding because summarily affirmed by the Court. See Hicks v. Miranda, 422 U.S. 332, 344 (1975); C. Wright, Law of the Federal Courts 495 (2d ed. I970).

${ }^{121}$ Of course, further litigation is probable if there is argument over the meaning of the Supreme Court decision, as is especially likely in the case of summary dispositions.

122 The Federal Declaratory Judgment Act provides for "further relief" against an adverse party to a declaratory judgment, which in appropriate cases will include iniunctions. 28 U.S.C. § 2202 (1970); see Wooley v. Maynard, 45 U.S.L.W. 4379 (U.S. April 20, 1977) ; Steffel v. Thompson, 415 U.S. 452, 478 (1974) (White, J., concurring). Of course, the Anti-Injunction Act, 28 U.S.C. § 2283 (1970), would not independently bar an injunction against state proceedings brought in contravention of the federal declaration, since it expressly allows injunctions "where necessary ... to protect or effectuate" federal judgments, id. Moreover, the Younger doctrine ought not be invoked to remit the federal plaintiff to state court to raise his plea of res judicata to a demonstrably impermissible prosecution. 
pealed by the state, its conclusive effect is more problematic. If the state were not bound as a party to the suit for declaratory judgment by res judicata, the judgment would have only the effect of persuasive but nonbinding authority in the state courts. ${ }^{123}$ To treat the declaratory judgment as a wholly noncoercive means of obtaining a determination of rights, however, would be inconsistent with the statutory language giving a declaration the "force and effect of a final judgment." ${ }^{124}$ Such a construction would also disregard both the legislative purpose to provide meaningful relief from uncertainty, ${ }^{125}$ albeit less severe than an injunction, and the impermissibility under article III of advisory opinions by federal courts. ${ }^{126}$ And as a matter of policy, there is no reason to decline to apply principles of finality to a declaration simply because it is unaccompanied by coercive relief. Generally, in litigation between private parties, declaratory judgments are accorded full res judicata effect. ${ }^{127}$ The fact that the state is a party does not alter the need for finality; if anything, principles of federalism reinforce ordinary justifications for finality and mandate that the state not be permitted simply to disregard the decision of a federal court when it is a party to the suit. ${ }^{128}$ While the Supreme Court has not yet resolved the issue, it seems clear that, as a matter of federal common law, declaratory judgments should be accorded some res judicata effect in the state courts. ${ }^{129}$

${ }^{123}$ The judgment would not be accorded the stare decisis effect that it would have in a subsequent proceeding within the same federal jurisdiction. See Steffel v. Thompson, 4I5 U.S. 452,482 n.3 (I974) (Rehnquist, J., concurring); United States ex rel. Lawrence v. Woods, 432 F.2d 1072 (7th Cir. 1970), cert. denied, 402 U.S. 983 (197I) ; State v. Coleman, 46 N.J. 16, 34-35, 214 A.2d 393, 402-03 (1965).

${ }^{124} 28$ U.S.C. \& $220 \mathrm{r}$ (1970); see Steffel v. Thompson, 4I5 U.S. 452, 477 (I974) (White, J., concurring); E. BorChard, Declaratory Judgments io-II (2d ed. I94I).

${ }^{125}$ See S. Rep. No. 1005, 73d Cong., 2d Sess. 2-6 (1934); Perez v. Ledesma, 40I U.S. 82, III-I6 (I97I) (Brennan, J., concurring and dissenting).

${ }^{126}$ See Steffel v. Thompson, 415 U.S. 452, 477 (1974) (White, J., concurring);

E. Borchard, supra note 124, at I0-14. But see Note, The Res Judicata Effect of Declaratory Relief in the Federal Courts, 46 S. CAL. L. REv. 803, 836-39 (1973).

${ }^{127}$ Restatement (Second) of Judgments $\$ 76$, at 23 (Tent. Draft No. 2, 1975).

${ }^{128}$ See Steffel v. Thompson, 415 U.S. 452, 477 (White, J., concurring).

${ }^{129}$ Although without explicit constitutional or statutory mandate, it is clear that federal judgments must be afforded full faith and credit by the state courts. See, e.g., Stoll v. Gottlieb, 305 U.S. I65 (I938); Degnan, Federalized Res Judicata, 85 YALE L.J. 7I4, 744-45 (1976). While cases decided under the regime of the Conformity Act of June I, 1872, ch. 255, I7 Stat. 196, suggest that the effect of a federal court judgment should be determined by the law of the state in which that court sits, see, e.g., Stoll v. Gottlieb, 305 U.S. at 170, with the establishment of the Federal Rules of Civil Procedure under the Rules Enabling Act, 28 U.S.C. $\$ 2072$ (1970), it appears that the effect of federal judgments should be a matter 
Of course, the immunity given the plaintiff in the declaratory suit will not be unqualified. Subsequent prosecutions under the statute will be permitted if they would not impeach the right declared. Additionally, a declaration of a question of law ordinarily will not bind the parties if by reason of changed circumstances for example, a reversal of decisional law - preclusion would result in unfair or inconsistent administration of the law. ${ }^{130}$

Assuming a declaratory judgment has preclusive effect, a further question is whether a person may estop the state in a subsequent prosecution on the basis of a declaratory judgment to which he was not a party. ${ }^{131}$ Of course, if the federal judgment has been affirmed by the Supreme Court, any individual may rely on it as controlling authority. In cases not reviewed by the Court, however, this question is more difficult. Generally, the requirement of mutuality of estoppel - which would prohibit defensive use of a prior judgment by a nonparty — has been steadily relaxed..$^{132}$ Still, where one party is a state and the matter declared is the unconstitutionality of one of its laws, nonmutual estoppel might be somewhat disruptive. It would permit any person to secure a dismissal of a prosecution brought under the statute so long as it remained unreformed, thus affording the unappealed decision of a lower federal court the practical effect of a Supreme Court decision. $^{133}$ Even so, a number of factors suggest that binding the state vis-a-vis other parties may be an appropriate accommodation of the interests at stake. First, the state could avoid

of federal law. See Williamson v. Columbia Gas \& Elec. Corp., I86 F.2d 464 (3d Cir. I950), cert. denied, 391 U.S. 92 I (195I); Degnan, supra at 766-73. See also Blonder-Tongue Lab. Inc. v. University of Ill. Foundation, 402 U.S. 313,324 n.I2 (I97I).

${ }^{130}$ See Restatement (Second) of Judgments, supra note $3, \S 68 . \mathrm{I}(\mathrm{b})$; Commissioner v. Sunnen, 333 U.S. 59I (1948). The justification for persisting in the prosecution in light of the prior judgment may be presented at the outset of the state trial to resist summary dismissal. If at that point the state court denies a proper motion for dismissal, further relief should be available in federal court. Alternatively, the state court defendant immediately might seek a federal injunction if the likelihood of a permissible prosecution were sufficiently small to support a showing of bad faith.

${ }^{131}$ In other contexts, federal courts have commonly held that a nonparty may rely on a prior federal judgment to estop a party to the prior suit, particularly when asserted defensively against a person who, as plaintiff in the prior action, lost on the issue in question. See, e.g., Blonder-Tongue Lab., Inc. v. University of Ill Foundation, 402 U.S. 313, 324-25 (1971) ; Bruszewski v. United States, I8I F.2d 4I9, 42 I (3d Cir.), cert. denied, 340 U.S. 865 (1950).

${ }^{132}$ See p. 1339 \& n.39 supra.

${ }^{133}$ The sources of this effect are, of course, distinguishable. In one case the supremacy clause obliges state courts to follow the Constitution as interpreted by the Supreme Court; in the other, state officials are bound as parties to a final lower federal court judgment. 
being bound by exercising its right of appeal to the Supreme Court, ${ }^{134}$ thereby obtaining a decision of general applicability. To the extent that this rule would encourage states to seek such review, fairness and predictability would be enhanced by a final declaration of rights. Second, while it could be argued that any given suit might be an inappropriate vehicle of appeal for the state, the state is never wholly free to choose the test case of the constitutionality of one of its statutes..$^{135}$ Third, despite the practical risk of summary dispositions which may not afford the state's claim a full hearing, it would appear that the state, appealing from an adverse federal judgment, would be less likely to be victimized by such summary dispositions than an individual appealing from state court on an often limited record. Finally, the specter of an endless queue of potential declaratory judgment plaintiffs, binding the state by the first successful suit, ${ }^{136}$ seems overdrawn in light of the infrequency with which persons satisfy justiciability requirements ${ }^{137}$ and the ability of federal courts to dispose summarily of frivolous claims. ${ }^{138}$ If the res judicata effects of a declaratory judgment were confined to the immediate parties, the protection afforded by a single judgment could be broadened by joining parties ${ }^{139}$ or framing a suit as a class action. ${ }^{140}$ Anyone who failed to obtain declaratory relief would

${ }^{134} 28$ U.S.C. \& $1254(2)$ (I970).

${ }^{135} \mathrm{See} 28$ U.S.C. \& 1257 (2) (1970).

Nonmutual estoppel would present a difficult question of the res judicata effect of a final declaratory judgment pending appeal. Ordinarily a final judgment on appeal is given res judicata effect, see Restatement (Second) of Judgments, supra note $3, \S \S 4 \mathrm{I}, 4 \mathrm{I} \cdot 3$, but in the case of declarations that a state statute is unconstitutional, it might be most appropriate to postpone preclusive effects until appeals are concluded.

${ }^{136}$ See Currie, Mutuality of Collateral Estoppel: Limits of the Bernhard Doctrine, 9 Stan. L. Rev. 28I, 285 (1957).

${ }^{137}$ See Steffel v. Thompson, 415 U.S. 452, 476 (I974) (Stewart, J., concurring).

${ }^{138} \mathrm{See}$ FED. R. Civ. P. 56.

${ }^{139}$ See FED. R. CIV. P. 20 (a). The joinder device is, however, of limited usefulness because of the requirement that the court otherwise have jurisdiction, see C. WRIGHT, supra note 120 , at 305 (1970), and that the claims be independently justiciable, see Younger v. Harris, 40I U.S. 37, 4I-42 (197I).

${ }^{140}$ See FED. R. CIv. P. 23 (b) (2), (3). A number of courts, however, have refused to certify challenges to the constitutionality of government action as class actions, see, e.g., Martinez v. Richardson, 472 F.2d II2I, II26-27 (Ioth Cir. I973), sometimes reasoning that if the practice or law were held unconstitutional with respect to one class member, the government would not continue to enforce the law against other potential class members, see, e.g., United Farmworkers v. City of Delray Beach, 493 F.2d 799, 81 2 (5th Cir. 1974), or that apparent differences in the situation of potential class members may make case by case adjudication preferable to class litigation, see, e.g., Ihrke v. Northern States Power Co., 459 F.2d 566, 572-73 (8th Cir.), vacated as moot, 409 U.S. 815 (1972). Unless genuine differences in situation compel case-by-case treatment, class certification should not be 
still be able to raise the unconstitutionality of the statute as a defense to a state prosecution, with an appeal of right to the Supreme Court. ${ }^{141}$

Another possible source of protection for nonparties distinct from res judicata is the argument that a declaratory judgment fosters reliance, such that those who are later prosecuted could maintain that they had not had the fair notice required by due process. ${ }^{142}$ However, such notice tends in practice to be largely fictional and arguments about reasonable reliance are inevitably somewhat circular; a nonparty's reliance is reasonable only to the extent that the unappealed federal judgment is binding on state courts. Absent a more compelling justification, the due process clause should not be viewed as an independent source of nonmutual estoppel.

\section{Conclusion}

With the rebirth of section 1983 after Monroe v. Pape, the courts began to fashion doctrines limiting both the substantive scope of the section 1983 action itself and the jurisdiction of the federal courts to hear such suits. While vague notions of federalism have often been invoked to provide support for such limitations, closer analysis, in the light of the history and purposes of section 1983 , has suggested that the courts have unduly restricted the potential of section 1983 to protect constitutional rights against state infringement.

One alternative, of course, would be judicial reexamination of these limiting decisions. It is, however, doubtful that the Court which has played such a major role in fashioning these restrictive doctrines will actively participate in their liberalization. Congressional action may be the more realistic alternative. Indeed, the current Congress is now considering legislation which would substantially revamp the section 1983 cause of action by in effect overruling a number of the Supreme Court's recent decisions which have reduced the effectiveness of the statute. ${ }^{1}$ S. 35 , for example,

denied, as that would deprive litigants of the protection against mootness which the class device provides, see Developments in the Law-Class Actions, 89 Harv. L. REv. I3 I8, 1464-66 (1976), as well as general access to the contempt power, id. at 1354 n.II9, to insure that government compliance is not limited to the immediate parties.

14128 U.S.C. $\S 1257(2)$ (1970).

${ }^{142}$ See Comment, Federal Declaratory Relief from Unconstitutional State Statutes: The Implications of Steffel v. Thompson, 9 Harv. C.R.-C.L. L. REv. 520, 557-58 (1974).

${ }^{1}$ See, e.g., S. 35, 95th Cong., Ist Sess., I 23 Cong. REc. S20I-05 (daily ed. Jan. ro, 1977) (Civil Rights Improvement Act of 1977). 
would eliminate governmental immunities, expand supervisory liability, eliminate absolute immunities for prosecutors, prohibit the application of doctrines of abstention or judicial exhaustion in the context of section 1983 suits, and substantially limit the preclusive effect of both the Younger doctrine and principles of res judicata. ${ }^{2}$

While greater elaboration and more explicit definition are needed before the legislative provisions dealing with forum allocation issues in section 1983 actions can be fully analyzed, it seems clear that Congress can and should constrict the scope of personal immunities, and eliminate the absolute immunities enjoyed by governmental bodies. Whether or not considerations of state sovereignty should serve as a constraint on judicial interpretation of section 1983 , these concerns do not limit the reach of congressional power under section 5 of the fourteenth amendment. Thus, in Fitzpatrick v. Bitzer, ${ }^{3}$ Justice Rehnquist, in upholding a Title VII action for back pay by state employees in the face of an eleventh amendment challenge, noted that "[w]hen Congress acts pursuant to $\S 5$, not only is it exercising legislative authority that is plenary within the terms of the constitutional grant, it is exercising authority under one section of a constitutional amendment whose other sections by their own terms embody limitations on state authority." 4

As Fitzpatrick indicates, whatever the considerations of limited judicial power and state sovereignty which have caused courts, faced with a century-old and open-ended statute, to limit the effectiveness of section I983's promised vindication of constitutional rights against unlawful state activity, further congressional action to affirm and broaden the reach of section 1983 undermines the legitimacy of those limiting concerns. Given the history and purpose of the fourteenth amendment, any appearance of a conflict between federalism and constitutional rights in the context of congressional action is illusory: congressional enforcement of constitutional rights against the states is of the essence of modern federalism.

\footnotetext{
${ }^{2} \mathrm{See}$ id.

${ }^{3} 427$ U.S. 445 ( 1976$)$.

${ }^{4} I d$. at 456. See also Tribe, Intergovernmental Immunities in Litigation, Taxation, and Regulation: Separation of Powers Issues in Controversies About Federalism, 89 HARv. L. REv. 682, 683-99 (1976) (arguing that the eleventh amendment was intended to be, and is in fact, only a limitation on the power of the federal courts to entertain actions against states, but that the amendment places no constraint on the power of Congress, acting under the fourteenth amendment, to abrogate state sovereign immunity).
} 